


\section{Presented by}

The Misses Hewitt

From the library of the late Mrs Hewitt 1922 

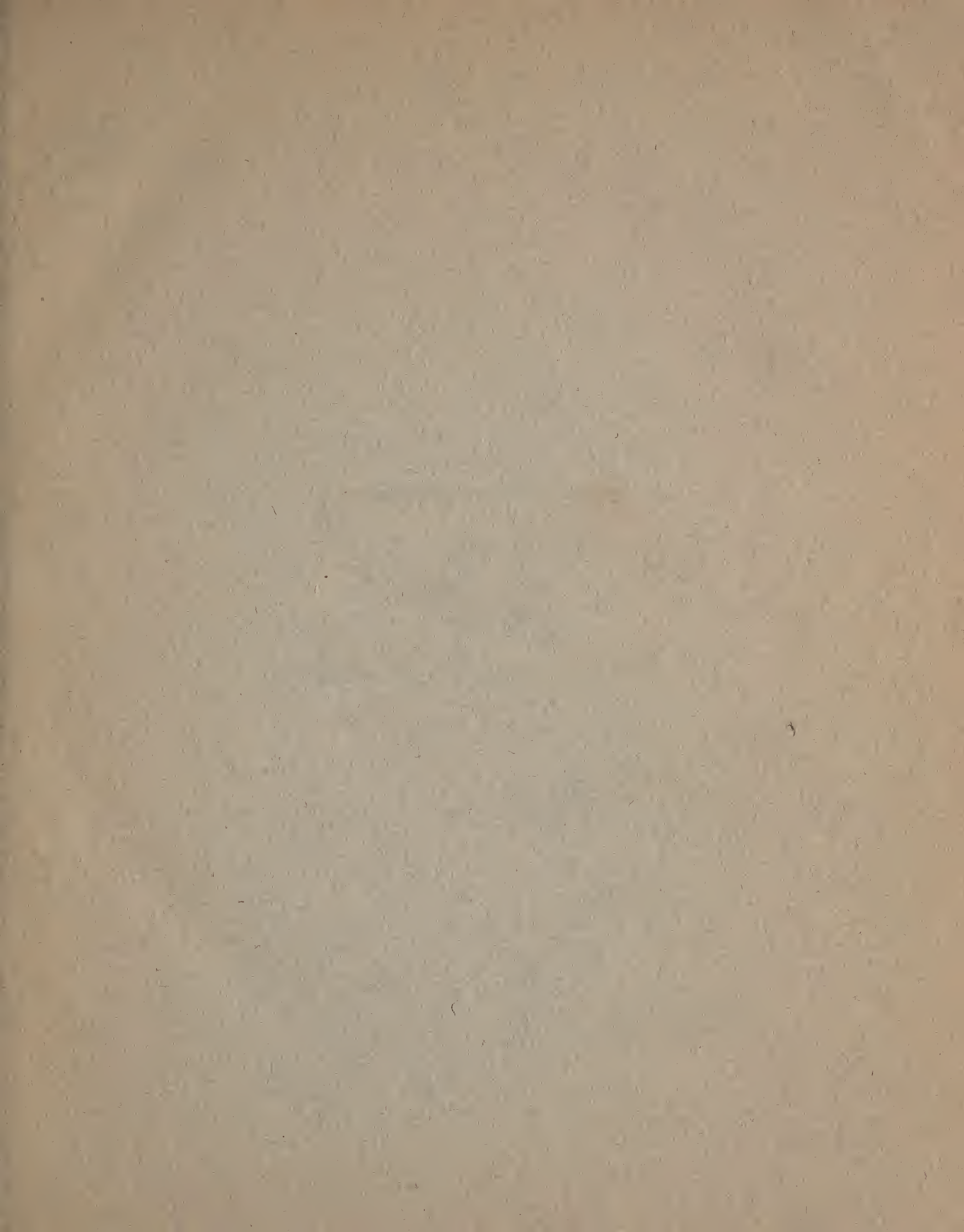





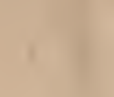




\title{
T REATISE
}

\author{
ON THE
}

CULTURE. AND. MANAGEMENT OF

\section{FRUIT-TREES;}

IN WHICH

A NEV METHOD OF PRUNING AND TRAINING IS FULLY DESCRIDED.

TO WHICH IS ADDED, A NEW AND IMPROVED EDITION OF

" OBSERVATIONS ON THE DISEASES, DEFECTS, AND INJURIES, IN ALL KINDS OF FRUIT AND FOREST TREES:"

$\cdots$

WITH AY

ACCOUNT OF A PARTICUTAR METHOD OF CURE, Published by Order of Government.

\section{By WILLIAM FORSYTH, F.A.S. AND F.S.A.}

GARDENER TO HIS MAJESTY AT KENSINGTON AND ST. JAMES'S, MEMBER OF THE CECONOMICAL SOCIETY AT ST. PETERSBURG, \&c. \&C.

\section{LONDON :}

Printed lig Nichols and Son, Red-Lion Paßage, Fleet-Street, FOR T. $N$. LONGMAN AND O. REES, PATERNOSTER-ROW; T. CADELL, JUN. AND W. DAYIES, STRAND; AND J, DEBRETT, PICCADILLX. 1502 . 



\section{TO THE KING.}

\section{SIR E,}

IT is now upwards of feventeen years fince Your Majefty did me the honour to appoint me Your Gardener at Kenfington and St. James's; during which time I have made a great variety of experiments on Fruit and Foreft Trees, and introduced the mode of Pruning and Training recommended in the following Treatife.

Your Majefty has, at different times, graciounly condefcended to examine the procefs, and been pleafed to exprefs Your approbation of the Improvements in fuch favourable terms, as have caufed my heart to overflow with unfpeakable pleafure.

Such encouragement from my Royal Mafter has ftimulated me to proceed with fo much alacrity
A 2
and 


\section{( iv )}

and perfeverance, as to overcome every difficulty that oppofed me, and to bring the fubjects treated of in this Volume to fuch a ftate of perfection as will, I flatter myfelf, in fome meafure render it worthy of Your Majefty's Patronage.

Permit me then, Sire, with the moft profound humility to lay this Work at Your Majefty's feet; and thus publickly to acknowledge my gratitude to the beft of Sovereigns, and the beft of Mafters, for the innumerable bleffings which under Him I enjoy, both as a Subject and a Servant.

That Your Majefty may long live to patronize the Arts and Sciences, and to reign over a loyal, brave, and happy People, is the daily prayer of

Your Majefty's

Moft grateful

And moft devoted

Humble Servant,

WILLIAM FORSYTH.

Fi⿹ 


\section{PR E F A E.}

To the many Publications that have appeared on the Management of Fruit and Foreft Trees, it may be thought fuperfuous to add; and, indeed, fo little am I accuftomed to the practice of writing, that I feel no fmall degree of reluctance in offering any; thing to public infpection; but an entire conviction of the advantages to be derived from the obfervations and directions contained in the following pages, joined to the importunity of many of the moft competent judges, has determined me to make my method of pruning and training, and the fuccefs attending it, as public as poffible.

Having long obferved the fanty crops both on wall and ftandard trees that have followed the ufual mode of pruning and training, I was led to make many experiments, in order to difcover, if it were poffible, a more fuccefsful method. Nor have my endeavours been in vain; for, after following a new mode for feveral years, I can with pleafure affirm, that the quantity of fruit has been remarkably increafed, and the quality greatly improved.

I have in the following pages ftated many faets, to evince the utility of the Compofition recommended, and to induce others to make a fair trial, which may be done at a very trifling expence.

I only requeft of thofe who entertain any doubts, that they will make choice of two trees of the fame kind, as near as may be in the fame ftate of health or decay, and having equal advantages of foil and fituation; let the dead, decayed, and injured parts be 
cut out; then to one of the trees apply the Compofition as directed in this Treatife, and leave the other to Nature: if proper attention be paid to the former, no great length of time will be neceflary to thew which method ought to be purfued in future.

I hope the candid reader will pardon me for dwelling a little . on this fubject. .It has been faid, that there is nothing new either in the Compofition or its application. It is certainly true, that Compofitions of various kinds have been tried; but no one has been attended with fuch great fuccefs as that which is defcribed in the following pages: indeed, they were generally made up in a novenly manner; and applied without properly preparing the trees; fo that little good could have been expected, even if the Compofition had confifted of proper materials. In thefe particulars I am perfuaded, that every impartial perfon will acknowledge that I have made great improvement. Former Compofitions have been made up of loam and cow or horfe-dung, of bees-wax, pitch, tar, chalk, rofin mixed with greafe, gums, \&c. It is granted, that fuch as thefe may fometimes be of ufe, but not in general; moft of them being liable to become hard, and to crack and peel off. I have tried them all, with but very little fuccefs. I have alfo tried a Compofition of tarras (which is ufed as a ccment for building under water).: this alfo cracked and peeled off after it became hard. Some of thefe Compofitions become fo hard, that, inftead of giving way to the new bark as it is produced, they cut and tear it, to the great injury of the tree.

The Compofition which I recommend is not liable to thefe inconveniences; it poffeffes an abforbent and adhefive quality, and is moreover of fuch a nature as not in the leaft to hurt the new and tender bark; for it eafily gives way to it and to the new wood as they advance. On applying it to trees which contain a ftrong acid, fuch as Oaks, Apple-trees, Apricots, \&c. when in- 
fected with the canker, that difeafe may be feen oozing through the Compofition and adhering to the outfide, like copper duft, or ruft of iron, and may be eafily rubbed off with the hand. This. appearance I never could obferve on the application of any other Compofition; : which confirms my belief that it acts as a ftrong fimulant.

When the wounds in fruit trees are-fo large as not to heal up in the courfe of a twelvemonth, I renew the Compofition annually... which, on its application, invigorates the trees, and feems to havethe fame effect on them as a top-dreffing of dung has on land.t.

I have been folicited by fome of my friends to add a chapier : on forcing Grapes, Peaches, and Nectarines; ; and to give a de-.feription of a houfe for that purpofe; but as it would fwell the book to too great a fize, and as the fubject is fully treated of by many others, it feems umeceffary to fay any thing. farther here, than juft to obferve, that the method of pruning and. training recommended in this book is equally applicable to trees in a forcing-houfe as to thofe on a natural wall. When Vines are trained ftraight up the rafters of hot-houfes, they throw out a few eyes only at top, and all the reft of the branch becomes naked; : but when trained in a ferpentine manner, they break equally.

Dwarf Peaches and Nectarines planted in the pits of forcing-. houfes thould be trained horizontally; in which mode they will produce much more fruit than when they are trained fan-fafhion.

It muft be obferved, that the Directions, \&c. in the following pages are calculated for the neighbourhood of London; it will, therefore, be neceffary to make allowance, in other climates, for the earlinefs' or latenefs of their feafons, both with regard to the time of fruit being in perfection, and alfo for planting, pruning, \& $\mathrm{c}$.

For the information of thofe who are not acquainted with practical gardening, the following explanation of what is called Heading-down is given. 
When young trees are planted out from the Nurfery, as foon as they begin to break in the Spring, they are cut down to three or four eyes, according to their ftrength, to furnith them with bearing wood: if this were not done, they would run up in long naked. branches, and would not produce one quarter of the fruit which they do when this operation is properly performed. The fame holds good in heading all kinds of old trees.

- An opinion prevails, particularly in thofe parts rvhere Appletrees are cultivated to any confiderable extent, that trees never bear well after heading-down, and that it frequently kills them. This may, no doubt, happen when they are improperly headeddown all at-once, by giving a fudden check to the fap, the few weak fhoots not having ftrength to drav up what is fupplied by the roots; and moreover, not being capable of theltering one anothicr; they are chilled by the cold; and fo rendered at leaft unproductive, if they are not totally killed. But if heading were done gradually, that is, if every other branch all over the tree were headed at a proper length, cutting as near to thofe parts where the fhoots appear as poffible, in the month of February or March, or even as late as May, in the courfe of the Summer they would throw out fine long thoots. Thefe fhould not be fhortened. the firft year, unlefs it be neceffary to fhorten a few to fill up the head of the tree with bearing wood, and that fhould be done in the following Spring; cutting them to fix or eight inches long, according to their ftrength. In the next Spring after the firft branches are headed, the remaining old branches may be cut out; and thefe will foon fill the head of the tree with fine bearing wood. In three years, if properly managed, trees fo headed will produce a much greater quantity of fruit aud of a better quality than they. did before the operation was performed. 
A

\section{TRE A T ISE}

ON THE

\section{CULTURE AND MANAGEMENT}

oz

\section{FRUIT TREES, \&c.}

\section{CHAPTER I.}

\section{OF APRICOTS*}

Different Sorts defcribed-Planting and Heading-The Management of decayed Trees-Pruning of Apricots, and hore to helter them from Cold.

THE Apricot, we are told, came originally from Armenia, whence it takes the name of Armeniaca, and was introduced into this country in 1562 .

* We fhall enumerate, under their refpective heads, the principal forts of fruit that are propagated in this country; with the time of their ripening, as near as poflible. It is to be obferved, however, that the diverfity of feafons, together with that of foil and fituation, will fometimes make a month of difference in the ripening of the fruit. 
Linnæus, according to the Sexual Syftem, arranges it in the twelfth clafs, Icofandria Monogynia * and comprehends in the genus Prunus, the Apricot, the Cherry, and the BirdCherry; making them only different fpecies of the fame genus.

Although the above-mentioned plants are arranged under the fame genus, yet the Cherry and Plum will never take upon each other, nor the Apricot upon the Cherry; but the Apricot will take upon all forts of Plums, except the Bruffels.

\section{The Names and 2ualities of Apricots commonly cullivated in} England, with the Time of their Ripening.

I. The Mafculine. This is a fmall roundifh fruit. It is the earlieft of all the apricots, ripening about the latter end of July; and is chiefly efteemed for its tart tafte. When fully ripe, it is of a red colour towards the fun, and of a greenifh yellow on the other fide.

2. The Orange. This is pretty large, but rather dry and infipid, and fitter for tarts than for the table. It is of a deep yellow colour when ripe, which is about the latter end of Auguft. This is confidered as the beft for preferving.

3. The Algiers. This is a flatted oval-hhaped fruit, of a ftraw colour, juicy, and high-flavoured. It ripens about the middle of Auguft.

4. The Roman. This is larger than the Algiers, rounder; of a deep yellow, and not quite fo juicy. It is ripe about the middle or latter end of Auguft.

* Moft of our eatable fruits are arranged under this clafs; and it is remarkable, that there is not one poifonous fruit to be found in it.

5. The 
5. The Turkey. This is larger, and of a deeper colour, than the Roman; its hape more globular, and the flefh firmer and drier. It ripens about the latter end of Auguft.

6. The Breda (brought from thence to England) is originally from Africa. It is large, round, and of a deep yellow colour; the flefh is foft and juicy. This is an excellent fruit, efpecially if ripened on a ftandard. It ripens about the latter end of Augurt.

7. The Bruffels. This is held in very great efteem on account of its bearing fo well on ftandards, or large dwarfs. It is of a middling fize, red towards the fun, with many dark fpots; and of a greenifh yellow on the other fide. This has a brifk flavour, is not liable to be mealy or doughy, and is preferred by many to the Breda; but when the Breda is planted as a ftandard, the fruit is more juicy and of a richer flavour. This ripens in Augut on a wall, but not before the latter end of September on ftandards.

8. The Moor Park, called alfo Anfon's, Temple's, and Dunmore's Breda. This is a fine fruit, and ripens about the latter end of Auguit.

9. The Peach Apricot. This was introduced from Paris, by his Grace the Duke of Northumberland, at Sion-houfe, in I767. It is the fineft and largent of all Apricots, and is generally thought to be the fame as the Moor-Park; but upon a minute examination the leaves will be found to differ. It ripens in Auguft.

"IO. The Black Apricot. This has been very lately introduced, by Sir Jofeph Banks, from France, in which country it is highly efteemed.

The trees that Sir Jofeph planted at his feat in Spring Grove, near Hounflow, bore fruit laft feafon, for the firft 
time in this country; but, in confequence of the wet and unfavourable weather, it did not arrive at perfection *. It ripens about the fecond week in Augurt.

To the foreguing may be added:

The Great Apricot. Holland Apricot. Provence Apricot. Alberge.

Angumoife. Blotched-leaved. Nancy Apricot, (a fine large fruit.)
The Dutch Apricot.

Grover's Breda.

Perfian.

Royal Orange.

Tranfparent.

Portugal Apricot, (a fmall fruit.)

For the accommodation of thofe who have fmall gardens, and yet with to have a regular fucceffion of fruit, we thall give abftracts of the larger felections; retaining thofe kinds only which are beft adapted for that purpofe; and of which one or more trees of a fort may be planted, according to the fize of the garden, or the demand of the family.

* Sirce writing the above, I have had the honour of paying Sir Jofeph a viftt at Spring Grove, where I had the pleafure of tafting one of thefe Apricots; and I think it will prove an acquifition well worth cultivating. The black colour of the fruit may perhaps, prejudice fome perfons againft it; but the flavour, in my opinion, is very good; and if it be confidered, that the wood of I 799 was not well ripened, owing to the rret feafon, there is little doubt, that, next year, if the feafon fhould be favourable, the flavour of the fruit will be greatly improved, and continue improving till the tree comes to maturity. The fcantinefs of the prefent crop of Apricots, Peaches, Nectarines, 8cc. may be attributed to the wood not being properly ripened laft year.

In Mayer's "Pomona Franconia," will be found a very good figure of the Black Apricot, called alfo the Alexandrian Apricot. 


\section{A Selection of Apricots for a fmall Garden.}

The Mafculine; the Roman; the Orange; the Breda: and the Moor Park.

Of the Planting, Pruning, and Training of Apricots:

The beft time for planting Apricots is in Autumn, as foon as the leaf begins to fall. The perfon who goes to the nurfery for the plants fhould make choice of thofe which have the ftrongeft and cleaneft ftems; and if he can procure fuch as have been headed down, (to ufe the phrafe of the nurferymen) of two or three years growth, they will bear and fill the walls much fooner than thofe which have not been fo treated. He thould make choice of trees with one ftem; or if they have two, one of them thould be cut off; for by planting thofe with two ftems the middle of the tree is left naked, and, of courfe, one third of the wall remains uncovered.

I know that it is the practice of many to make choice of trees with the fmalleft ftems; but thefe always produce weaker thoots than the others.

\section{On preparing the Borders.}

If the borders wherein the trees are to be planted be new, they fhould be made two feet and a half or three feet deep, of good light freth loam. If the trees are to be planted in old borders, where the earth has been injured by the roots of the 
former trees, it will be neceffary to take out the old mould at leaft three feet deep, and four feet wide, filling up the hole with frem loam, and taking care to plant the trees about eight inches higher than the level of the old border, to allow for the finking of the earth, that they may not be too deep in the ground: but this will be more fully treated of in the chapter on Pear-trees.

When the trees are planted, they fhould by no means be headed down till the month of A pril, or May, when they begin to throw out frefh Thoots. Strong trees thould be cut a foot from the ground; and thofe that are weak, about half that length.

- In backward feafons, they thould not be headed down fo early; never until the buds are fairly broken; always obferving to cut floping towards the wall, and as near to an eye as poffible, that the young leading thoot may cover the cut; [See Plate I. Fig. 1.] which operation thould be again performed in the next March or April. The fhoots that are then thrown out muft be trained horizontally, to cover the wall. The number of thefe to be left ought to be from three to fix on each fide, according to the ftrength of the main thoot; taking care to rub off, with the finger and thumb, the foreright thoots all over the tree, except a few which may be wanted to fill up the wall, near the body of it. [See Plate I. Fig. I.]

In the fecond year, the horizontal thoots muft be fhortened in the fame manner, according to their growth; and fo on every year till the wall thall be completely covered from top to bottom.

It is a frequent practice with fome gardeners, to head down the trees at the time of planting; which very often proves fatal to them. 


\section{Of old and decryed Trees.}

It has been the general practice to train wall-trees in the form of a fan, which occafions the fap to rife too freely to the: top, leaving the lower part almont naked; fo that fcarcely. one quarter of the wall is covered with bearing wood.

In that cafe, it will be neceffary to cut down the whole of: the tree, as near to the place where it was budded as poffible; remembering always to cut at an eye or a joint. If there thould be any young fhoots on the lower part of the tree, it: will be proper to leave them, training them horizontally, which will check the flow of the fap, and thereby render them much more fruitful.

Very frequently, when large branches have been cut off in? a carelefs manner, and the wounds left to nature, the whole: tree is infected with the gum and canker; which, if not checked, will in a thort time totally ruin it.

The beft remedy in this cafe is, carefully to pare off the cankered part of the bark with a draw knife, or other convenient inftrument. You will frequently find the white inner bark infected, which muft alfo be cut away, till no appearance of infection remains; this may be eafily known by the brown or black fpots, like dots made with a pen, of which not one. muft be fuffered to remain.

All the branches fo cut and pared fhould be immediately. covered with the compofition in a liquid ftate; the preparation and application of which will be particularly defcribed in. another place.

As we fometimes fee walls with all the trees infected, it will in that cafe be moft prudent to cut every other tree, leaving

the 
the reft for a fupply of fruit till thofe which are cut begin to bear; this will be in the fecond or third year.

When trees are in a very bad condition, they fhould be cut in a partial manner, taking off the wort branches firft, particularly thofe in the middle of the tree, always cutting as near to the graft as poffible; or every other branch may at firtt be taken out, leaving the reft to bear; by which means there will be a fupply of fruit while the other parts of the tree are renovating. It fhould be remembered, however, that all the cankered bark muft be cut off without lofs of time; otherwife the new wood will be infected.

Old trees thus headed down will fometimes throw out very ftrong and vigorous thoots, which it may be neceflary to top, as it will caufe them to throw out fide-fhoots, and foon fill up the wall with fine bearing wood; but they thould never be fuffered to have any foreright fpurs, except little dugs. The topping fhould be done in the beginning of June, which will caule the tree to produce fine bearing wood for the next year. Thofe trees muft be pruned in March following, fhortening the thoots from fifteen to fix inches, but according to their ftrength, always leaving the ftrongeft thoots longeft.

Wherever the knife has been ufed, the compofition muft be immediately applied.

After the fall of the leaf, it will be proper to unnail the young thoots, leaving only a few to prevent the tree from being broken by the wind. By this method they will be more expofed to the fun and air, which will ripen and harden the wood much more fpeedily than if they be left nailed.

I have a great diflike to Autumnal pruning of fruit trees; of all kinds of ftone-fruit in particular; for by pruning at that feafon 
feafon you feldom fail to bring on the canker; and no fruit trees are more liable to this difeafe than the Apricot. The reafon is obvious: the great acidity in thefe trees, the expofure of the wounds, and the dormant tate of the fap, predifpofe to mortification; whereas, in fpring, when the fap is beginning to flow, and will follow the knife, the lips will quickly grow. If the branches are fmall, a frefh bark and frefh wood will in one feafon completely cover the wound; but if large, a time proportionate to their fize will be occupied ; this procefs, however, is manifeftly much accelerated by the application of the compofition, which excludes the air and wet from the air and fap veffels of the tree.

It may now be proper to give a few directions for covering Apricots, to prevent the bloffom from being deftroyed by frofts, cutting winds, \&c.

In fevere weather, they ought to be covered before the flowers begin to expand; for I have often feen the bloffoms drop off before they opened.

The beft covering is old fifh-nets, which thould be put on three-fold; and if a few branches of dry fern are ftuck in among the branches before the nets are put on, they will aflift greatly in breaking the force of the high winds. It is a common practice, to cover with mats in the night, and to take them off in the day; but this, by frequently expofing the trees to the cutting winds, does more harm than good. Another practice is, to cover with branches of fpruce-fir and yew; but thefe, being too clofe, encourage a blight, and caufe the leaves of the trees to curl, and the fhoots to break very weak; whereas the nets admit a free circulation of the air, and at the fame time break the force of the wind. When 
it happens to rain or fnow in the forepart of the night, and freeze towards the morning, we find the drops hanging in icicles on the methes, while the tree is almot dry.

When the thoots become pretty long, and the leaves expand to cover the fruit, it will be neceffary to keep the net clear from the tree, by placing forked fticks, from fix inches to a foot long, between it and the wall; this will prevent the fhoots and leaves from growing through the net. The forked end of the fticks thould rent againft the melhes of the net.

A few trees for an early fupply may be planted on a South afpect, according to the fize of the garden, and the demand there may be for the fupply of the family; but a Weft afpect is far preferable for the general crop. Thofe who wirh for a late fupply may have fome trees planted on an Eaft afpect.

The Breda is the beft and the richeft-flavoured for a ftandard, although the Bruffels is frequently preferred; but I would by no means recommend planting more than three trees of each fort in a garden, as ftandards; as it is not one year in ten that a tolerable crop is produced from them.

The Breda, the Bruffels, and the Moor-Park, Thould always be planted on an Eaft or Wett afpect. 


\section{CHAPTER II.}

OF PLUMS.

Different Sorts of Plums cultivated in England-Of Plant-heading and Training them-Of Standards in Orchards, and Dwarfs in Gardens-The Management of old decayed Trees.

THE Plum is generally fuppofed to be a native of Afia, and the Damafcene to take its name from Damafcus, a city of Syria.

This genus of plants is arranged by Linnæus in the twelfth clafs of his Syftem.

The Names and 2ualities of thofe Plums which are commonly cultivated in England, reith their Time of ripening.

I. The Jaunhative, or White Primordian, is a fmall plum, of a yellow colour, and mealy. It ripens in the latter end of July, or beginning of Augurt. One tree will be fufficient for à garden. 
2. The Early Damak, commonly called the Morocco Plum, is middle-fized, and the flelh good. It ripens about the beginning of Augurt.

3. The Little Black Damank Plum is a rich fruit, a good bearer, and is ripe about the latter end of Augurt.

4. The Great Damank Violet of Tours. This is a fine rich: plum of a bluifh colour, and is ripe in Auguft.

5. The Red Orleans Plum is large, of a rich juice, and is ripe in the latter end of Augurt.

6. The Fotheringham is an excellent plum, of a dark red, and the juice rich; there is hardly any plum that excels it.

7. The blue Perdrigon is of a very good tafte, and ripens: in Augurt.

8. The white Perdrigon Plum is a pretty good fruit, and. has a fweetifh tafte mixed with tartnefs. It ripens in the beginning of September.

9. The red Imperial Plum, or red Bonum Magnum, is a great bearer, and moftly ufed for baking. It is ripe about the latter end of September.

10. The white Imperial Bonum Magnum, or Egg Plum, White Holland, or Mogul Plum, is a large fruit, and, like the red, moftly ufed for baking. This is a great bearer, and ripens about the beginning of October.

Ir La Royal is a fine plum, equal to the Green Gage, but a thy bearer. It is of a red colour, and ripens in the latter end of September.

1.2. Little Queen Claudia is a fmall rich fruit, ripe in September.

I3. Large Queen Claudia, or Dauphiny. This is an excellent plum, of a yellowilh green, and ripens about the beginning of October.

I4. The 
14. The Green Gage Plum* is of an exquifite tafte, and eats like a fweetmeat. Its colour and fize fufficiently diftinguifh it from any other. It ripens in Auguft and September.

15. Drap, d'Or is a good plum, and a plentiful bearer. It is ripe about the latter end of September.

16. The Chefter Plum is rich, and a great bearer. It is ripe about the latter end of September.

17. The Apricot Plum is large and fweet, and is ripe in the beginning of October.

18. The Maitre Claud is a large round whitifh plum; the juice is very brifk, though fweet. It is accounted among the beft white plums that we have, and ripens about the beginning of October.

19. The Myrobalans, or Cherry Plum, is a middle-fized fweet fruit, and ripens about the beginning of September. This plum is frequently planted for ornament, as it bloffoms early.

20. La Mirabelle, of an amber colour, and fmall, is full of juice, and excellent for fweetmeats. It bears well, and is ripe about the beginning of September.

21. The Brignole Plum. This is efteemed the beft plum of any for fweetmeats; the flefh is dry, but of a rich flavour. It is ripe about the latter end of September.

22. The red Diaper Plum is large, and of a very high flavour. It ripens about the beginning of September.

23. The Saint Catharine Plum is one of the beft, and is much ufed for confectionary; it is alfo very good for the table, having a rich fweet juice ; and is a good bearer, hanging the longeft of any upon the tree. I have had them in ga- 
thering fix weeks. It ripens about the latter end of September.

24. The Imperatrice, or Emprefs Plum, has an agreeable flavour, and ripens about the middle of October. This is one of the lateft plums, and fhould not be gathered till it begins to fhrivel; it will then eat like a fweetmeat, and make a great addition to the table in the latter end: of October and beginning of November.

25. Monfieur's, or the Wentworth Plum, is a large fruit refembling the Bonum Magnum. It ripens about the beginning of October, and is good for preferving, but too tharp to be eaten raw.

26. The Winefour, a Yorkthire plum, is one of the bett for preferving. It is ripe in October.

\section{To the above may be added":}

Admirable.

Black Damafcene.

Black Pear.

Blue Matchlefs.

Damas noir de Tours.

Don Carlos's.

Double-flowered.

Early blue Primordian.

Early red Primordian.

Early Amber.

Early Tours, or Precoce de

Tours.

Early Violet.
Ear̉ly Orleans.

Fine Early Plum.

Jacinthe, or Hyacinth.

'Koa's Imperial.

La Prune Suiffe.

La Prune valeur Valentia.

Matchlefs.

Maugeron.

Mufcle.

Perfian.

Red Queen Mother.

Royal Pea.

Royal Dauphin. 
St. Julian.

Semina.

Small White Damafcene. Spanifh Damafcene.

Striped-leaved.

True Prune.
Verte-dock, or Verdock. Whitton, or Nutmeg.

White Bullace.

White Orleans.

White Pear.

White Perdrigon.

\section{A Selection of Plums for a Jmall Garden.}

The Jaunhative; Early Damank; the Orleans; La Royal; Green Gage (different forts); Draps d'Or ; Saint Catharine; and Imperatrice. The Magnum Bonum for baking, and the Winefour for preferving.

On the Choice, Planting, Pruning, \&f: of Plum-Trees.

When you choofe your trees, let the fame directions be obferved as in the choice of Apricots. Choofe clean ftraight plants with fingle ftems; as thofe with two never make handfome trees either for walls or ftandards. Manage the border as before directed for Apricots; digging the holes the fame width and depth, and loofening the bottom; then fill up the holes with fine frefh loam, or the mould that was ufed the preceding year for melon and cucumber beds; and be careful to keep the mould a proper height above the border, and the roots of your trees as near the furface as poffible, fpreading them horizontally. If there are any tap-roots, they thould always be cut off, as thould alfo the fine hairy roots, as they are liable to get mouldy and rot, and thereby bring on a putrefaction of the mould about the root of the tree. If the roots are not fpread near the furface of the ground, it will 
prevent the fun and air from penetrating to them; and the fruit, of courfe, will not have fo fine a flavour.

Never cut the ftems of young plum-trees when firft planted, but leave them till the buds begin to break; then you may head them down to five or more eyes, always obferving to leave an odd one for the leading thoot: remember to cut floping towards the wall, and as near to an eye as poffible. Thus managed, the hoots will foon fill the wall with fine wood. If you find that fome of the hoots are too luxuriant, you may pinch the tops off with your finger and thumb, about the beginning of June in the firlt year after planting: by doing which you will obtain plenty of wood to fill the bottom of the wall. A great deal depends on the firft and fecond year's management of your trees.

The diftance from each other at which plum-trees thould be planted againft a wall depends on the height of the wall. If the wall be ten feet high, which is the common height, they may be planted at eight yards diftance from tree to tree ; but if the wall be twelve feet high, or more, feven yards will be fufficient. For my part, I prefer a wall of ten or twelve feet, which will be found high enough, if the branches are trained horizontaliy; by which means your trees will be much more fruitful, and not grow fo luxuriantly.

By training an upright fhoot on your Plums, as directed for Pears, you will get fine kind thoots from the fides. The leading thoot thould be fhortened, leaving it from one to two feet long, according to its ftrength. If the leading thoot be very ftrong, you may top it twice in the fummer, as directed for lears, and at the fame time that you top them; repeating the fame every year till the wall is filled to the top. I would always recommend, where it is convenient, to allot 
one wall for Plums and another for Cherries, as they always thrive beft by themfelves.

As you will have Plum-trees to fpare, that were planted between Pear-trees, when they begin to meet, they fhould be planted againt another wall, or planted out as Dwarf Standards. Thofe which you intend for Standards thould be prepared in the following manner. The year before you mean to tranfplant them, cut in the fide-Thoots at different lengths, from one foot to three, according to the fize of the trees; fuffering them to grow rude all the fummer, neither nailing-in nor cutting the fide and foreright fhoots. Some time during the winter open the ground round their roots, and cut in the Arong ones (which will caufe them to put forth fine young fibres); then fill in the earth. In the following autumn, or during the winter (the fooner the better), you may tranfplant them out as Standards*. If you intend to plant them againft a wall, never cut the fide-lhoots, but only the roots; by this method the trees will bear fruit the firf year after tranfplanting, and there will be a great faving of time and money. I have often tranfplanted old Plum-trees that have been headed down, that have made very fine roots, which I have divided, and thereby obtained four or five trees from one, cutting them fo as to form them into fine heads. Some that were tranfplanted in 3798 were in full bloffom in I799, producing fome fruit, and this year ( 1800 ) bearing a full crop.

* In tranfplanting of trees, efpecially large ones, I confider it to be of great confequence, that they be placed in the fame pofition (that is, having the fame parts facing the fame points of the compafs) as formerly. If you take notice when a tree is cut down, you will find that three parts in four of the growth are on the North fide. 
The ground in the borders and quarters where frein trees are to be planted thould be well trenched, two fpits deep at leaft, to give the roots room to run into the frefh-ftirred ground.

When you plant trees without ftirring the mould, they feldom thrive well.

When Plum-trees are planted for Standards in an orchard which is to be kept for grafs, they thould be in rows at the diftance of twenty yards from each other. If in the kitchen garden for Standards, I would always recommend the planting of Dwarfs. You may train the tree up to have a ftem of about three feet high, at the diftance of feventeen yards. If the garden is laid out with crofs-walks, or foot-paths, about three feet wide, make the borders fix feet broad, and plant the trees in the middle of them. In the Royal gardens at Kenfington, which are very long and narrow, and where the winds are very hurtful, I have planted two rows of Appletrees, intermixed with other fruit-trees, alternately, one row on each fide of the middle walk (which runs the whole length of the garden), at the diftance of feventeen yards from each other. I have alfo made crols-walks of three feet broad, at the diftance of feventy yards, with borders on each fide fix feet wide, having two rows of trees in each border, about twelve or fourteen feet afunder. Thefe Dwarf trees are very ufeful in breaking the force of high winds, and are at the fame time of fuch a height that a man ftanding on the ground may gather the fruit. As Plum-trees may be planted in the fame manner and for the fame purpofe as the above, you can have the quarters clear for crops for the kitchen, and a free air will be admitted, which you can never have if you plant Efpaliers: 
Efpaliers: Dwarf Standards can be kept to what fize you pleafe; they look much handfomer than Efpaliers, and produce a greater quantity of fruit.

\section{On pruning and reforing old and decayed Plum-Tres.}

I have reftored Phum-trees, fome of which were fo far decayed as to have only from one to two or three inches of bark. left; they are now completely filled up with found wood, with large heads, which at four years growth filled a wall fixteen feet high, and are at this time full of fine fruit; fome of the ftems are feveral inches in circumference, bearing treble the crops produced by young trees that have been planted three times as long as they have been headed down.

Where the trunks are become hollow, I always cut out all the loofe rotten parts, and alfo cxamine the roots, cutting off what is rotten, injured, or decayed. This method thould be purfued with all hollow and decayed trees; and, if properly executed, they may be fo completely filled up, as fcarcely to leave a mark behind, even where the wood is totally decayed.

I have had thoots from Plum-trees which have been headed, that have grown upwards of feven feet long, and as large as a walking-ltick, in one fummer; this hould never be fuffered; but they thould be pinched off with the finger and thumb, in the beginning of June, clofe to an eye or a bud; unless the wall be filled to the top; in which cafe they fhould never be cut while they continue to bear handfome fruit. Before they begin to ceafe from bearing, you mut always begin with Mortening every other thoot, leaving them only from fix inches to a foot long, and nail them in till the fecond 
year, taking care to rub off the fuperfuous and frong foreright thoots; by that time they will begin to bear; then cut out the others that have done bearing: by this method you will keep the trees in a flourithing ftate. When the branches are thus managed, they will frequently throw out fmall dugs, or foreright thoots, about an inch or two long, which will flower next year. They thould never be fhortened till after the fruit is fet and become about the fize of a large pea; by that time the leaves will have covered the fruit, and be able to protect it from the inclemency of the weather. You may now Ghorten thefe Moots clofe to the fruit, which will leave them from one to two inches long. This method I have practifed with great fuccefs for feveral years. By leaving thefe thort foreright moots, the fruit is protected till it is out of danger of being killed by the froft, or ftunted by the cold North and North-weft winds that happen about the latter end of March and beginning of April. The cold chilling rain and fnow, which are alfo very injurious to the fruit, will be thrown off by the branches franding out from the trees. I by no means like to fee great fpurs ftanding out from the wall; for they are always fure to be injured by the froft and cold winds. [See Plate II. Fig. 2.] When the thoots are left naked, I have often feen the plums turn yellow, and drop after they have grown to a confiderable fize, from their being expofed to the cold frofty winds and rain*. Plums are more tender than any other fort of Itone fruit, owing to the flower cup dropping fooner than that of Peaches, Nectarines, \&c. They are very liable to decay, after cutting off large limbs or branches, which always brings on the gum

* In cold and frofty weather, Plums muft be covered in the fame manner as Apricots.

and: 
and canker, if it be left to Nature to perform the cure. I would, therefore, recommend the application of the compofition (in the fame manner as directed for other forts of fruittrees) to every thoot where the knife touches, as foon as the trees are cut and nailed.

If you with your fruit to be large and fine, you muft take care to thin it where it is too thick; but that muft not be done too foon, left it thould be pinched by the cold. The fruit ought to be of the fize of a fmall marble, and well theltered by the leaves, before you attempt to do this. Never pull off the leaves that thelter the fruit, till it is full-grown and begins to turn. This will be more fully treated of, when we come to the management of Peaches and Nectarines.

I have taken up feveral old trees from the walls, when they have grown too near each other, and planted them out as Standards, at the fame time fhortening their branches to form handfome heads, which are now full of fine fruit. Thefe trees would, by any other perfon, have been thrown to the fagot-pile. 


\section{CHAPTER III.}

OF PEACHES。

Different Sorts of Peaches defcribed-Of the Soil-Of planting, heading, pruning, and training-Method of making IncifionsOf covering Peach-Trees, watering, \& $\&$.

THE Peach, Perfica, is a native of Perfia, and was intro: duced from thence into Europe. It belongs to the twelfth clafs of Linnæus.

The following are the Sorts cultivated in this Country.

[N.B. Thofe marked with an Afterink (*) adhere to the ftone, and are by the French called Pavies.]

1. The White Nutmeg Peach. This Peach is fmall, and the juice fugary. It is only efteemed as being firlt ripe. It is in eating in July, and foon grows mealy.

2. The Red Nutmeg is a great bearer, and valued for its early maturity. It is of a bright vermilion colour, and has a 
fine muky taife. This Peach is much efteemed, and ripens about the beginning of Augunt.

3. The Early Avant has an agreeable flavour, and ripens in Auguft; but is apt to be ftringy.

4. The Small Mignonne is very red on the fide next the fun, , and the flefh has a rich vinous juice. It is ripe about th middle of Augut.

5. The Anne Peach (which is faid to have taken its name from Mrs. Anne Dunch, of Pufey in Berklhire, where it was firft raifed) is a fine early fruit. It is ripe about the middle or latter end of Augutt.

6. The Royal George Peach comes in foon after the former; the flower is large and white; the fruit of a dark red towards the fun, and full of a fine rich juice. It is ripe about the latter end of Augurt.

7. The Royal Kenfington is one of the beft Peaches that we have; of a high red colour next the fun, and of a yellowilh colour next the wall; it is a good bearer and not liable to be blighted. The fleth is full of rich juice. It ripens about the latter end of Augut, or beginning of September $\uparrow$.

8. The Yellow Alberge is of a tolerable fize and good tafte, but thould be perfecly ripe before it is gathered; otherwife it is good for nothing. It is ripe about the middle of Auguft.

9. The White Magdalen. This Peach is feldom high. flavoured, unlefs it be forced, and then it is excellent. It ripens about the middle of Augun.

+ This handfome Peach, I am told, was, with fome others, fent from France to her Najefty, upwaris of twenty years ago. I have therefore taken the liberty to give it the above name, that it may not be confounded with Mr. Grimwood's Kenfington Peach. When I came to Kenfington, in $17 S_{4}$, I found it mentioned in the Catalogie as a new Peach from France.

I0. The 
10. The Early Purple. This fruit is large, of a fine red colour, and full of rich vinous juice. It is an excellent Peach, and is ripe about the latter end of Augurt.

Ii. The Large, or French Mignonne, is a beautiful large red Peach, and has a fweet high-flavoured juice. This is one of the beft French Peaches, and is ripe the latter end of Augurt.

12. The Bourdine is a pretty large fruit, of a fine red towards the fun; the juice is rich and vinous; the tree is a good bearer, efpecially when old, and the fruit highly efteemed. It is ripe about the middle of September. This tree will do very well in ftandards, and produce plenty of good fruit.

13. The Chevreufe, or Belle Chevreufe. This is a good peach : it is of middling fize, and of a beautiful red colour; the juice is rich and fweet. It ripens about the beginning of September, and is a plentiful bearer.

I4. The Red Magdalen is large, and full of a rich fugary juice of excellent flavour. It is a very good Peach, and ripens in the beginning of September.

I 5. The Early Newington, or Smith's Newington, is of a beautiful red colour towards the fun, full of a fugary juice, and ripens in the beginning of September.

16. The Mountauban is of a deep red, inclining to purple, next the fun; but pale towards the wall. It has a fine melting Alefh, with a rich juice; and the tree is a plentiful bearer. It is ripe in the latter end of Anguft.

17. The Malia Peach. This is of a fine red next the fun, and has a white melting flem; the tree is a good bearer, and the fruit ripens in the beginning of September.

18. The Nobleffe. This is a large Peach, of a bright red colour ton ards the fun: the fleit is melting, and the juice 
very rich in a good feafon. This tree is a good bearer, and the fruit is ripe in the beginning of September.

19. * The old Newington Peach is of a fine red colour, has a high vinous-tafted juice, and is efteemed a good Pavie. It ripens about the latter end of September.

20. The Chancellor is one of the beft fort of Peaches, and of a fine red colour next the fun; the $\mathrm{k}$ in is thin, the flefh melting, and the juice very rich. It ripens about the beginning of September.

2I. The Bellegarde Peach, or Gallande, is very large, and of a deep purple colour towards the fun; the flefh melting and full of a very rich juice. This is a fine Peach, and ripens about the middle of September.

22. * The Lifle Peach is of middling fize, and of a fine violet colour next the fun; the fleth is melting and full of a vinous juice. It ripens about the middle of September.

23. The Rofanna is of a fine purple colour next the fun, and has a rich vinous juice. It is reckoned a good Peach, and is ripe about the middle of September.

24. The Rambouillet (commonly called the Rumbullion) is pretty large, and of a fine red colour next the fun; the fleth is melting, and the juice vinous and rich. It ripens about the latter end of September.

25. The Admirable is a very large and beautiful Peach, finely coloured with red towards the fun; the flem is melting, and the juice fugary and of an exquifite tafte. It ripens about the middle of September.

26. * The Bellis (La Belle de Vitry). This fruit is of a pale red towards the fun; the flefh is white, and the juice vinous and rich. It is ripe in the latter end of September.

$2 \%$ * The Portugal is of a beautiful red towards the fun. 
and generally fpotted; the flefh is firm, and the juice rich and vinous. It ripens late in September.

28. La Teton de Venus (Venus's Breaft). This is a middlefuzed fruit, fomewhat longih; the fide next the fun is of a pale red, the flefh melting, and the juice fugary and rich. It ripens about the latter end of September.

29. La Pourprée (the late Purple). This fruit is large and of a purple colour; the fleth is melting, and the juice fugary and rich. It ripens about the beginning of October.

30. The Nivette is of a bright red next the fun, and of a yellowith caft towards the wall; the fefh is melting, and full of a rich juice. This is an excellent Peach, and ripens about. the middle of September.

3. * The Monftrous Pavey of Pomponne. This Peach is very large, and of a round form; the fleth is white and melting; it is of a fine red colour towards the fun. This. ripens in the latter end of October.

32. * The Catharine Peach is a fine large fruit of a round make, and of a beautiful red colour towards the fun. The fleth is melting, and full of a rich juice. The pulp is improved by its lying three or four days before it is eaten. It ripens about the latter end of October; but there are not many fituations where it ripens well. It is a plentiful bearert.

+ This is an excellent Peach for forcing, and will be highly acceptable to thofe who are fond of fuch as adhere to the flone; and, as it is of a bedutiful colour it will make a very handfome appearance at table. Or, this fruit might have part of a wall appropriated to itfelf, and have the lights of the Peach-houfes (after forcing is over), or Melon lights, fixed upon a temporary frame again $\mathrm{f}$ the wall. This would greatly forward the ripening of the fruit in bad feafons; and, as the tree is a good bearer, it would amply recompenfe any one for the trouble, by furnighing a fupply of fruit for the table till the middle of November. This would alfo affift in ripening the wood well for the fucceeding year. 
33. The Bloody Peach. This is of a deep red next the fun; the flem is alfo of a deep red. It feldom ripens in England without forcing; but is reckoned excellent for baking and preferving.

34. The Royal (La Royale). This is a large round Peach, of a deep red next the fun; the flem is melting and full of a rich juice. It ripens in the latter end of September.

35. The Cherry Peach (Pêche-cerife, of Duhamel,) is fmall and globular. It is of a beautiful red colour towards the fun, and of a whitith wax colour on the other fide. Its colour, which refembles that of the Pomme d'Api, gives this little Peach a beautiful appearance. The fleth is melting, and the juice has a tolerably good flavour. On a dry foil and good expofure, it ripens about the beginning of October.

36. Grimwood's New Royal George is a high coloured Peach, and of a fine flavour. It ripens in the latter end of Auguft, or beginning of September $t^{\circ}$.

37. The Superb Royal is a fine large Peach of a red colour towards the fun, and pale on the other fide. It ripens in September.

$3^{8}$. The Queen Charlotte nearly refembles the fmall Mignon, and ripens about the fame time.

39. The late violet is efteemed a very fine peach, and ripens in September.

t This Peach feems to be the fame as the Royal George. 
To the foregoing may be added,
Allen's Royal.
Bourdeaux.
Low's large Melting;
Buckingham Mignonne.
Mallacotan.
Carlinle.
Millet's Mignonne.
Double Swalch.
* Pavie Admirable.
Double Bloffomed.
* Pavie Royal.
Double Mountagne.
Peche de Pau.
Dwarf Orleans.
Ronald's early Gallande.
Eaton.
Fairfcot's.
Sion.
Ford's Seedling.
Smooth-leaved Royal George.
Hem凡irk.
Steward's late Gallande.
Vanguard.
Violette hative.
* Incomparable
White Bloffomed.
Lord Falconberg's Mignonne.

\section{Peaches proper for a fimall Garden.}

The Early Avant; Small Mignonne; the Anne Peach; Royal George; Royal Kenfington; Nobleffe; Early Newington; Gallande; Early Purple; Chancellor; Nivette; the Catharine; the late Newington.

Of the Planting, Pruning, Training, \&c. of Peach-Trees.

Peaches require a lighter foil than Pears and Plums; and a light mellow loam is beft. If the natural ground fhould be a ftrong brick mould, or rather inclinable to clay, it will be neceffary 
neceffary to take out fome of it, particularly when you firnt make the borders, and mix with it fome light mould, fand, or old lime rubbilh. At firf making the borders, you thould take out the earth where the trees are to be planted, as before directed for Apricots; and keep working the reft with rotten leaves, or ftreet-dung, and the above mixture; throwing them up, as early as you can fpare them, in ridges rough from the fpade, which will let the froft and fun penetrate and meliorate the ground.

If the ground fhould be wet, make fome drains acrofs the borders, to lead the water from the roots of the trees to a drain made along the middle walk. If the ground thould have a flope, you can very eafily convey the water off when the fprings are near the furface; but if the wet be occafioned by rains, and the ftiffnefs of the ground holds the water, you fhoula give the border a proper flope to carry it off from the roots of the trees. Fill the crofs drains, leading to that along the middle of the walk, with old bricks or ftones at bottom, and at top with rough gravel *, which will keep the ground dry; at the fame time laying it lloping from the wall, fo as to throw the water that falls in heavy rains toward the middle walk, where it will foon foak into the ground. When water is fuffered to ftand about the roots of tender trees in frong land, it is fure to bring on the mildew, which will fpoil and render them good for nothing but the fagot-pile. Sometimes, indeed, I have recovered them, by moving them to another afpeet. All the French Peaches are very liable to mildew on ftrong land.

* The drains fhould be deep enough to have two feet of mould above the gravel; which will prevent their being liurt in trenching the ground.

Where 
Where there is not a proper defcent to carry off the water, the bottom of the main walk thould be filled up with brickbats or ftones, and the fmall itones raked from the quarters of the garden, making a dry drain along the middle 9 inches wide, or more, covered with bricks or ftones. The walk, when finithed, thould have a gentle rife in the middle, in order to throw the rain water toward the edges.

Where the foil is a four wet clay, it will be neceffary to throw into the bottom of the border brick-bats covered with lime rubbifh, or core from the fkreenings of lime; then water it, and when nearly dry ram it well, which will convert it into a hard folid furface, and prevent the roots of the trees from penetrating the wet earth below. It will alfo ferve to carry off the water to the drains.

With regard to the choice of Peach Trees, the directions already given for Apricots will ferve. They hould be procured in the latter end of October, or beginning of November, as foon as the leaf begins to fall; and, if poffible, the ground be ready beforehand.

The earlier you go to the nurfery the better, to mark and take up the young trees; for he that goes firt has the greater choice.

The ground, if new borders, fhould be well trenched to receive the trees; if to fupply the places of others which havebeen removed, or where trees have died, all the old roots fhould be carefully takenout, and freh mould put in where the old was taken away; remembering to raife the new mould a proper height above the old; as it is a very great hurt to fruit trees, when they are planted too deep: if they are not kept up above the level of the old ground at firt, they feldom thrive well. When the trees are planted, water the roots well to icttle 
fettle the mould, letting it remain for fome days till the water is abforbed; then tread the mould, and fill the holes up to tho top; obferving the fame rules as before given in cafe of dry weather, letting your freh-planted trees remain unpruned till. the Spring.

When you fee the buds begin to thoot, if the trees be maiden trees of one year's growth, you may head them to five or more eyes, according to their ftrength; then rub on a litele of the compofition where you cut off the top, obferving to cut it noping, as before directed, and as near the top buds as may be, and alfo: to rub off the foreright thoots. When the young Thoots have frength, nail them to the wall, to prevent their: being broken by the wind. If the leading fhoot be very nrong, pinch off the top of it about the beginning of June, which will make it throw out fome fine frong thoots to help to fill the wall. None of the fhoots hould be fuffered to grow. too long during the firt and fecond years; which may always be prevented by pinching the ends of them; but they fhould never be topped, when the tree fends out fine kind fhoots, till the fpring following, when you may prune them, according to the ftrength of the tree, and the quantity of wood it has made during the preceding fummer, leaving your fhoots from fix to twelve inches long; by which means you will foon be able to fill the lower part of the wall. It is too common a practice to lay-in the fhoots at full length, taking off only the points of the branches, which generally, after a few years, lcaves the walls. quite naked: whereas if attention were paid to the training, efpecially for the firf four years, you could always fill the walls with fine bearing wood from top to bottom, and the trees could produce a great deal more fruit, and of much. finer quality, than when they are run up in the former.way; for 
thofe trees, in general, are fo weak that they have not ftrength to bear good fruit. The third year, if care be taken to manage the trees properly in fummer, you may bring them into a bearing ftate. If the ground be ftrong, they will grow very vigoroufly; in that cafe, you muft pinch all the ftrong: fhoots about the month of June, which will make them throw out fide-moots; thefe, if not laid-in too thick, will make fine bearing wood for the fucceeding year. If you fuffer the frong thoots to grow to their full length, they will be large and fpongy, and will neither produce fruit nor good wood for the following year. Weak thoots thould never be nailed, although they may be full of bloffom, as they never bear good fruit. Sometimes weakly trees are covered over with bloffom; but if too much fruit be fuffered to remain on them, they will be weakened fo much that they will never recover. In that cafe, I would recommend picking off the greater part of the fruit, to let the tree recover its ftrength. When you prune trees in the above ftate, obferve never to prune at a fingle flower-bud; if you do, you will be fure to kill the thoot; or, at lean, it will die as far as the next wood-bud. [See PLate III. Fig. 2.]

On obferving, you will find fome thoots, and fometimes whole trees, with nothing but fingle flower-buds. Thefe forts of thoots thould be laid-in at full length. Always obferve the next branch that has got fome wood-buds, and cut them clofe, that they may produce fine wood to fupply the place of thofe that have only fiower-buds, which may be cut out next year.

When Peaches come into a bearing ftate, you will, in general, fee two flower-buds clofe together; if you look between thefe flower-buds, you will fee what is called a wood.

bud: 
bud; you thould always cut at fuch double buds; as from between them come out the lhoots that produce the fruit for next year.

If you obferve the above rules, you cannot miftake in pruning your Peaches. [See PL A TE III. Fig. 2.]

When the trees come into a bearing ftate, you may keep them in a flourifhing one by proper management, and attention to the Summer pruning. I have often topped the ftrong Thoots twice in the courfe of the Summer, before I could get them to produce fine kind bearing wood. I have often had thoots that grew, in the courfe of one Summer, upwards of fix feet in length, and as thick as my thumb. When fuch fhoots as thefe are laid in near their full length, the lower part of the wall will be left naked [See the PLATE, Fig. 1.] ; befides, thele ftrong thoots exhaut the tree of its ftrength, and never produce good wood when you neglect to top them in Summer. I would recommend to cut out fuch thoots when the trees are pruned in the Spring, and to leave only the fine kind bearing wood (which you may know by two fmall leaves where the flower-buds will be in the following year; the ftrong (hoots have only one leaf bud at each eye); always re. membering to lay the branches as horizontally as you can, which will check the growth of the thoot, and make the wood. much finer, and fit for bearing the fucceeding year. You fhould always rub off all the ufelefs fide- Thoots that cannot bo nailed in againt the wall, leaving only the beft, and laying them in about three inches apart. Be very particular to pick off all the fide-Thoots that come out near the tops of the branches; which, if left, would weaken the fruit-bearing branches for next year. This thould be done as foon as you can lay hold of thefe hoots with your finger and thumb: if you fuffer them to grow ftrong, they will hurt the fruitbearing thoot. 


\section{Of Pruning, Training, and Nailing old Peach-Trees.}

When the trees run up to the top of the wall, leaving about three fourths of it naked, [See PLATE III. Fig. 3.] the beft way is to cut them as far back as you can find any young. thoots or buds. You muft always leave fome young thoots or buds on Peach-trees, otherwife you endanger the life of them.. Never head them as you would Apricot, Apple, or Pear-trees. If you cut or head down Peach-trees without attending to the caution given above, you run a great rifk of killing them; but if there are a few young thoots, the top may with fafety be cut off, juft above them, as they will lead the fap up and produce ftrong branches, which thould be topped as you would do a young tree to fill the wall.

It is more difficult to procure new wood from old Peachtrees than from any other, except Nectarines. I have often. made incifions in the old branches, about the joint, cutting out a piece from one to three inches according to the fize of the branches. [See PIATE XI. Fig. 2.] This thould be done in feveral places of the tree, to furnifh it with young wood; always rounding the edges where the incifion is made, which thould be above the joint, and as near to it as may be. 'The operation thould be performed in the month of April; but never cut off the old branches, unlefs you perceive fome young thoots making their appearance. When they are about three or four inches long, cut off the old branch, which will caufe the frefh young wood to make a rapid progrefs the firt: fummer, and you will have fine fruit on them the following year.

Always 
Always ufe the Compofition where you cut off old branches: obferving to round the edges, and cut out the canker which. you find in the old bark where the branch was amputated.

In Peaches, the canker is of a brown colour; and, in the bark, it appears in fmall fpecks or dots, as if made with a pen. All thefe thould be cut out clean; for if any part of the canker remain, it will affect the new wood as it begins to grow. Wherever you fee the gum oozing, you may be certain that the canker is not quite eradicated. - [See the Chapter on the CANKER.]

In the latter end of April it will be neceffary to look over your trees, and rub off what fuperfluous foreright thoots remained after going over them the firft time. Indeed, if you were to examine the trees once every fortnight, it would be fo much the better, as by fo doing they can be kept in perfect order. I have fo accuftomed myfelf to look over my trees, that $I$ do it as I walk about my ordinary bufinefs, which faves a great deal of time. Care hould be taken not to let the thoots get too long before they are tacked to the wall, left they thould be broken by the wind. I do not, however, approve of nailing the young wood too foon; for, by fo doing, the heat of the fun will occafion them to grow too faft.

You may fave fome of the largeft and ftraightent of the Shoots that are cut off, and run them in * among the fmal? branches of the trees to prevent them from being broken by the wind. This will fave a great deal of fummer-nailing:

* That is, let the middle of the branch run in be on the out fide of the thoot that you wifh to preferve, and the ends tucked under the two adjoining branckes. After the fall of the leaf, it will be neceffary to take out thefe loofe branches; which will give the thoots more liberty, and admit the fun and air to ripen the wood before the fpring: proning. 
I mean this for the fecond Summer-nailing. At the time you do this, carefully take off all the fide fhoots that come out from the tops of the young branches.

When the fecond nailing is done, if you thould find any very frong fhoots, they thould be cut out, leaving the fine kind fide thoots that have been produced fince the firft topping; but only thofe that will bear fruit. If the Autumn thould prove fine, the trees will continue in full leaf to the end of October, and fometimes to the end of November.

When the leaves begin to fall, take a foft broom, and brufh it gently over the branches of the trees, in order to take off as many of the leaves as you can, without hurting the buds. Remember, however, to brum upward; for if you bruth downward you will be very liable to break the buds.

As foon as all the leaves are off, I would advife to unnail the young branches that were nailed in during the Summer, leaving the ftrong ones to keep the tree faft to the wall. By thefe means, the branches, being loofe from the wall, will receive the benefir of the fun and air, to ripen and harden the young wood, which will not then be fo liable to be killed by. a hard winter. Leaving the trees fo till the Spring, when you begin to prune them, there will be great choice of fine bearing wood to fill the walls.

The nails and fhreds that were laid up in Autumn, when the branches were unnailed, thould be pointed and picked. during the wet weather in Winter; they will then be fit to ufe again. The threds that have been ufed in Summer thould be foaked in boiling-hot foapfuds for three or four days, which will kill the eggs of earwigs and other infects, fo very deftructive to Peaches.

After the trees are cut and nailed, if the weather thould be frofty, 
frofty, it will be neceffary to cover them when the flowers begin to open. Some cover the trees with yew, and others with branches of fir, laurel, \&c. but old netting is the beft covering; and it thould be put on threefold, as directed for Apricots. When the leaves begin to cover the fruit, and the weather is likely to be fine and fettled, the netting fhould be taken off by degrees, but by no means all at once. By the forked fticks, as before obferved, the nets may be kept at what diftance you pleafe; but never be in too great hafte to uncover the trees, nor fuffer the fhoots to grow through the merhes of the nets; for, when that is the cafe, a great many. of them will be broken in taking off the nets. The trees. thould be uncovered in cloudy weather, or when it is likely to rain; if the nets be taken off in clear weather, the leaves are liable to be hurt by the fun. Be careful, in taking off the foreright and fide fhoots, not to expofe the fruit; rub them off near the extremities, leaving thofe which you.want to fill up the wrall as low on the branch as poffible, at the fame time leaving only one for a leading thoot. When the fruit is about the fize of a fmall marble, begin to thin them; which operation muft be left to the judgment of the perfon who does it; but it fhould be according to the ftrength of the tree. This ought to be done very regularly, that the fruit may be equally difperfed over the tree. If left too thick, it will not have room to fwell: this frequently happens. If the tree be very ftrong, you may leave from three to fix Peaches on each thoot; according to the ftrength and length of the branch.

I have obferved, that where the Compofition was applied to prevent the fap from being exhaled by the fun and air, all the trees that were very much loaded with fruit were not in the leait hurt; while the trees that were treated in the com- 
mon way were greatly injured, and often killed, when they have had a great crop.

In very dry feafons, it will be neceffary to make a large bafin round each tree; or, rather, make up an edge along the whole border with mould, as you would for a bed to bed out plants in a nurfery; then give the trees a good watering, and mulch the border (which thould be from two feet and a half to three feet broad) with fome very rotten dung or leaves, which will keep the roots of the trees moift, and prevent the ground from cracking. Water the trees once a week during dry weather, and fprinkle the branches and leaves every other day, in the afternoon, with the engine, preffing your forefinger over the mouth of the pipe, in order to fpread the water very fine. By thefe means you will keep the trees clean and free from infects; always remembering not to fprinkle them when the fun is on them, nor too late in the evening, as the former fcorches the leaves, and the latter is apt to bring the mildew on the tender forts of Peaches. If you find any of the trees infected, leave off fprinkling them, or water them with clear lime-water, as hereafter directed; but this fhould always be done in warm weather. By frequently fprinkling the trees with lime-water, and throwing it plentifully on the underfide of the leaves, where the Acarus, or red Spider, is montly found, you will in a thort time extirpate that deftructive infect.

The next thing to be done is, to look over the trees, and take all the late fide-thoots, which would not ripen, off the wood fit to bear the following year; taking care, however, to keep the fruit thaded; and never fuffer the leaves to be picked off till the fruit be grown to its full fize; then begin to take off fome of them, to let the fruit attain its natural colour.

This 
This may be done once a week, in a gradual manner; by which method the fruit will continue much longer in fucceffion, than if the leaves were picked off all at once; in the latter cafe, the fruit all ripens at the fame time; but, by. thinning at different times, there will be a regular fucceffion for the table.

It is a bad practice to pick off the leaves of Peaches before the fruit is grown to its natural fize. The thade of the leaves nourithes the fruit very much; and, if you obferve, wherever the leaves are picked off the fruit will be fmall, ftunted, and ill-flavoured. Remember to hang up the bean-ftalk (as hereafter defcribed) before the fruit begins to ripen, in order to get rid of the earwigs, \&c. otherwife they will greatly injure the Peaches. - [See the Chapter on Insects.]

I would recommend planting fome trees of the early Peaches againft Eaft or North walls; for, by fo doing, you will have a regular fucceffion of fine Peaches till the late forts, againft the South and Weft walls, come in ; but never plant late forts on a North or Eaft wall. You may plant Peaches. between Pears and Plums till they meet each other; then tranfplant them againft other walls, or where dead trees have been taken up.

The following are the Sorts that I rould recommend to be planted againft North and Eaft Walls, viz.

Early Avant ; Early Ann; Early Mignonne; Royal George; Red Magdalen; Royal Kenfington; Nobleffe; Grofs Mig. nonne, and Millet's Mignonne. 


\section{CHAPTER IV.}

OF NECTARINES.

A Defcription of Nectarines cultivated in England, and the Method of Planling, Pruning, and Training them.

THE Nectarine (properly fo called from Nectar, the poetical drink of the Gods) was introduced here about the year 1.562, and belongs to the twelfth clafs of Linnæus.

This fruit differs from the Peach in nothing more than in having a fmooth rind, and the fleth being firmer + .

The Varieties which are cultivated in this Country are,

I. Fairchild!s Early Nectarine. This is one of the earlient; it is a fmall round fruit, of a beautiful red colour, and well fravoured; and is ripe about the middle of Auguft.

2. * Newington Nectarine. This is a fine fruit, of a beau-

+ Thofe marked with an afterifk adhere to the ftone. 
tiful red colour next the fun, and yellow on the other fide. It has an excellent rich juice, and ripens about the middle of September.

3. The Elruge Nectarine is faid to have been firft cultivated by Gurle, a Nurferyman at Hoxton, in the time of Charles the Second. It is of a middle fize, of a dark red or purple next the fun, and of a pale green on the other fide. It has a foft melting pulp and vinous juice, and is ripe in the latter end of Auguft, or beginning of September.

4. The Scarlet Nectarine is of a fine fcarlet colour next the fun, but of a pale red next the wall. It ripens in the latter end of Auguft, or beginning of September.

5. * Brugnon, or Italian Nectarine, is of a deep red next the fun, and of a pale yellow on the other fide; it has a rich flavour in a good year, and ripens in the latter end of Augurt, or beginning of September.

6. * The Roman Red Nectarine is a large fruit, of a dark red colour next the fun, but of a yellow colour on the other fide; and when full ripe it thrivels; the pulp is then replete with a rich juice. It is ripe in September.-This Nectarine has a fmooth leaf, and the Newington a jagged one: which is one of the moft effential differences by which thefe two excellent fruits are diftinguifhable from each other.

7. Murry Nectarine is of a reddifh colour toward the fun, and of a pale green toward the wall. This fruit has a tolerably good flavour, and ripens about the middle of September.

8. Temple's Nectarine is of middle fize, of a pale red colour toward the fun, and of a yellowith catt next the wall. This fruit, when quite ripe, thrivels; the pulp is then full of rich juice of a fine flavour. It ripens about the middle of September, or beginning of October. 
9. * Golden Nectarine. This is a handfome fruit of a foft red colour toward the fun, and yellow on the other fide. It has a rich flavour, and is ripe about the beginning of October.

I0. The Peterborough, or late green, Nectarine (called alfo the Vermath), is of middle fize, round thape, and always of a green colour; the fleth is firm, and, in a good feafon, tolerably well flavoured. It ripens about the middle of October.

The Violet Nectarine is of a middle fize, and a purple colour next the fun, but pale on the other fide; it has a vinous flavour, and ripens in the latter end of Augurt, or beginning of September.

\section{To the foregaing may be added:}

Anderfon's Nectarine.

Aromatic.

* Black Newington.

Clermont.

De la Taille.

* Early Pavie.

* Genoa.

Luncomb's Black.

* Mufk Violet.
Newfoundland.

New White.

Princefs Royal.

* Rogers's Seedling.

Royal Chair d'or.

* St. Omer's.

Tawny, ripe in September.

White, ripe in Auguft and

September.

\section{A. Selection of Nectarines for a fmall Gardert.}

Fairchild's Early Nectarine; Elrurge; Scarlet; Newington; Red Roman; and Murry. 


\section{Of the Management of Nectarines.}

It is unneceffary to fay much on this head, as the management of Nectarines is almont the fame as that of Peaches.

The fame rules mult be obferved with regard to pruning and cutting-out difeafed parts; and the fame attention will be neceffary during the fummer; obferving, in particular, not to lay-in the wood too thick.

On account of the fmoothnefs of the fkin of the Nectarine, it fuffers much more from millepedes (or wood-lice), earwigs, \&c. than the Peach; it will, therefore, be neceffary to hang up a greater number of bundles of bean-ftalks about thefe than about other Fruit-trees. Wafps are alfo very deftructive to Nectarines, and the trees are very liable to be infeited with the red fpider; thefe are to be deftroyed as hereafter directed.

Let the wall, with the ftems and branches of the trees, be carefully infpected, and all the fnails about them picked off and deftroyed. The young fnails frequently commit great depredations on the leaves before the fruit is ripe.-[See the Chapter on INSECTs.]

It may, perhaps, be neceffary to obferve here, that after the fall of the leaf the young thoots thould be unnailed, in order to harden the wood; and in hot weather form bafins on the borders, and mulch them, as directed for Peaches.

The fame mode of watering with the engine is alfo to be obferved, in dry hot weather.

Do not omit to thin the fruit when grown to a tolerable fize; but never pick off the leaves till the fruit be full-grown;

G 2

obferving 
TREATISE ON THE CULTURE, \&c.

obferving the rules already laid down for Peaches. It will anfwer equally well with Nectarines as with Peaches, to plant fome trees on an Eaft wall, which will continue the fucceffion much longer than if all were planted in the ufual afpects.

In the fummer of I 800 , which was dry and hot, we had a Weft afpect which was fo much inferted with the red fpider that I expected the trees would have been totally deftroyed. In February following, I had the wall well-wathed with foap and urine mixed, as alfo the items and branches of the trees. (This munt be done before the buds begin to open, and in the forepart of the day, that the trees may get dry before the evening; but never in frofty weather). Afterwards, wherever I faw any appearance of the fpider, I watered the trees with clear lime-water, as directed in Chapters III. and XXVIII. Thefe trees are now in a perfectly healthy ftate; but in fome gardens, where thefe precautions have been neglected, many of the trees are entirely killed. 


\section{CHAPTER V.}

\section{OF CHERRIES.}

Different Sorts; and the Propagation, Planting, Pruning, and Training, of them-How to preferve them from Insects.

CHERRIES are faid to have come originally from Cerafus, a city of Pontus, from which Lucullus brought them, after the Mithridatic war, into Italy. They fo generally pleafed there, and were fo eafily propagated in all climates into which the Romans extended their arms, that, within the fpace of a hundred years, they grew common as far as the Rhine, and were introduced into Britain about Ann. Dom. 55 *

* It is fuppofed by many, that Cherries were firft introduced into this country in the reign of Henry the Eighth ; but Lydgate, who wrote his poem called "Lickpenny" before the middle of the fifteenth century, or probably before the year 1415, mentions them in the following lines, as being commonly fold at that time by the hawkers in London ftreets :

Hot pefcode own began to cry,

Straberys rype, and Cherryes in the ryse.

Ryce, rice, or ris, properly means a long branch; and the word is ftill ufed in that Senfe in the Weft of England.

Cherries 
Cherries belong to the twelfth clafs of Linnæus's Syftem; Icofandria Monogynia.

\section{A Short Defcription of the principal Cherries cultivated in England.}

1. The fmall May Cherry is the firnt ripe, and requires a good wall. One or two trees of this kind may be fufficient for a large garden. It is ripe in June.

2. The May Duke comes in about the fame time as the former, but is larger : it is an excellent Cherry, and bears well againft a wall.

3. The Archduke, if permitted to ripen properly, is an excellent Cherry. It is ripe in June and July.

4. The Hertfordhire Cherry is a fort of Heart, but firmer and of a finer flavour than Hearts in general. It does not ripen till the latter end of July, or beginning of Augurt, which renders it the more valuable, as it fucceeds more early Cherries.

5. The Bleeding Heart, or Gafcoign's, is a very large Cherry of a long form, and dark colour; it has a pleafant tafte, and ripens in the latter end of July.

6. Harrifon's Heart is a fine Cherry. It was introduced from the Eaft Indies by Governor Harrifon*, grandfather to the prefent Earl of Leicefter, and firt cultivated at his feat of Balls in Hertfordihire : fome of the trees, I am informed, he prefented to George the Firtt; and they are at this time in

* Governor Harrifon went out Governor of Fort St. George in December I 710 , and returned home in $1>19$; and it is probable that he brought this Cherry home with him: if fo, fome of thefe trees in Kenfington Gardens mult be upwards of eighty years old.

a flou- 
a flourifhing ftate, bearing fine fruit, in Kenfingtan Gardens. This Cherry is ripe in July and Auguft.

7. The Black Heart is a fine Cherry, too well known to require defcription.

8. The Morello, or Milan Cherry, is a very fine fruit when kept till the month of October; and makes a very great addition to the deffert at that time of the year. This is the beft Cherry that we have for preferving, and for making CherryBrandy.

9. The Carnation take its name from its colour, being red and white. It is a large round Cherry, but not fo fweet as the Duke Cherry. It ripens in the latter end of July.

Io. The yellow Spanim Cherry is of an oval thape and amber colour, and is a fweet pleafant fruit. It is ripe in Auguft and September.

I I. The Corone, or Coroun Cherry, refembles the Black Heart. This is an excellent fruit, and a good bearer. It ripens about the beginning of Auguft.

12. The Lukeward comes in foon after the former, and is alfo a fine pleafant fruit, and a good bearer. It ripens in the beginning of Auguit.

I3. The Graffion. This is fuppofed by many to be the fame with Harrifon's Heart; but, upon a clofe examination, I find it to be a different Cherry: its flefh is firmer and the ftone flatter. It ripens in July and Auguft.

I 4. Ronalds's large Black Heart Cherry, introduced into this country in the year 1794 from Circafia. Mr. Ronalds, nurferyman at Brentford, and the only perfon, to the beft of my knowledge, who has cultivated it in England, fent me fome of the fruit this Summer, 1801. It is a fine large Cherry, a great bearer, and will, without doubt, be valuable as a forcing 
forcing fort. This Cherry, in my opinion, is well worth cultivating. It ripens in the beginning of July.

15. Frafer's Black Tartarian Cherry * is a fine large fruit.

16. Frafer's White Tartarian Cherry is white and tranfparent. Thefe Cherries are excellent bearers, but particularly the black kind : the fruit is of a fine brikk flavour, and they ripen early.

17. The Lundie Gean, cultivated at Lord Vifcount Duncan's, near Dundee, is black, and almoft as large as a BlackHeart Cherry. It is now common in the nurferies about Edinburgh ; and Meffrs. Gray and Wear have had it for fome years in their nurfery at Brompton-park.

18. The Tranfparent Gean is a fmall delicious fruit.

From the Black Cherry, which is fuppofed to be a native of England, are raifed, by feeds, the black Coroun, and the fmall wild Cherry, of which there are two or three varieties, differing in the fize and colour of their fruit. I would recommend planting thefe in parks and pleafure-grounds, as the trees grow to a great fize, and have a beautiful appearance. The fruit will be food for birds, and fo the means of preferving the finer fruit, in the garden and orchard, from their depredations. The wood alfo of thefe trees is very ufeful for turners and picture-frame makers. Stocks to graft upon are

* The Tartarian Cherries were brought from Ruflia in the Autumn of the year $1 / 96$ by Mr. John Frafer, of Sloane-fquare, Chelfea; well known for his indefatigable induftry in collecting many curious plants, and other natural curiofities, in America and the Weft Indies. He fays, that thefe Cherries are natives of the Crimea, and that he purchafed them of a German, who cultivated them in a garden near St. Peterfburg. This man had but few plants of them at.that time, and fold them as a favour at ten roubles a plant. Mr. Frafer afterwards faw them in the Imperial gardens, where they were fuccefsfully forced in pots. 
generally raifed from the feed of this fort. Thefe trees will thrive in poor land, where fcarcely any other forts will.

The Clufter Cherry is planted more for ornament, or cu. riofity, than for any other purpofe.

To the above may be added:

A mber Heart.

Black Mazard.

Church-hills.

Double-bloffomed.

Fleminh Heart.

Grofs Goblet.

Holman's Duke.

Jeffrey's Royal.

Kenfington Duke.

Large Spanifh Cherry.

Late Large Morello.

Montmorency.
Ox Heart.

Purple Heart.

Red Heart.

Spanifh Black.

South's large Black.

Swedifh Black Heart.

Tradefcant's.

Turkey Heart.

Weeping.

Wentworth Heart.

White Heart.

Proper Kinds of Cherries for a fmall Garden.

The May Duke; the large Duke Cherry; Archduke; the Black Heart; Harrifon's Heart; Ox Heart; Turkey Heart, and Kenfington Duke Cherry.

Planting, Pruning, and Training of Cherry-Trees.

In the choofing and planting of young Cherry-trees, the fame rules are to be obferved as are given for Apricots, Peaches, 
and Nectarines; and they muft in like manner be headed down the firft year.

In pruning Cherries, never thorten their thoots; for moft of them produce their fruit at the extremities, the fhortening, or cutting-off of which very frequently occafions the death of the thoot, at leaft of a great part of it. The branches, therefore, thould be trained at full length. I have often feen the whole tree killed by injudicious pruning. Wherever the knife is applied, it is fure to bring on the gum, and afterwards the canker, which will inevitably kill the tree if no remedy be applied to the wounds.

I have headed down a great many Cherry-trees which were almoft paft bearing, and fo eaten up with the gum and canker, that what few Cherries they bore upon old cankered fpurs were not fit to be fent to the table.

In the years 1790 and I79 I I cut, or headed down, fifty trees. The operation was performed in the months of April and May in each year. Thefe trees made fhoots from three to five feet the fame fummer, bore fine Cherries the next year, and have continued to bear good crops ever fince.

To the above trees I applied the Compofition. At the fame time I cut down twelve trees in the fame row, but did not apply the Compofition: thefe twelve trees all died in the fecond and third year's after. We now gather more Cherries from one tree where the Compofition was applied, than we did from the whole number formerly; being alfo much finer and larger fruit.

When Cherry-trees are very old, and much injured by large limbs having been cut off (which will infallibly bring on the canker and gum, and, if no remedy be applied, in a thort time kill the trees); or if there are great Spurs left ftand- 
ing a foot perhaps from the wall (See PLATE IV. Fig. 2.); the beft way to bring them to have fine heads, and to cover the wall, is to head them down as low as poffible, taking care to leave fome fmall thoots, if there are any; if not, leave a bud or two at the ends of fome of the hoots. Sometimes you will have a great difficulty to find any buds. If that be the cafe, in the Spring, before you mean to head the trees, make fome incifions in the branches (See Plate XI.) This fhol 11 be done on different branches, at the moft convenient places for filling the wall with good wood. The fize of the incifions thould be from one to two inches, according to the largenefs of the branches; obferving to make them juft above the joint where the buds fliould come out. If you cut juft below a joint, the fhoot will die as far as the next bud or joint; and, of courfe, injure the tree, if no remedy be applied.

The time for performing this operation is in March, April, or May. The above method of making incifions is only recommended where there are no young fhoots or buds, and when the tree is in the laft ftage of the canker.

Where you have a few young thoots, or buds, cut down the head as near to them as you can, and take great care to cut out the canker till you come to the found bark. The canker makes its appearance in Cherry-trees in the fame manner as it does in Peach and Nectarine trees, and may be eafily difcovered by an attentive obferver. If any gum remains, it muft be cut or fcraped off: the beft time for doing this is when it is moiftened with rain; you can then fcrape it off eafily without bruifing the bark. This operation is very. neceffary; and if it be neglected, the difeafe will increafe rapidly. 
Wherever the bark or branches have been cut off, the edges thould be rounded, and the Compofition applied.

The general way of pruning Cherry-trees has been to leave great fpurs, which continue to increafe till they ftand upwards of a foot from the wall, and become as thick as a man's arm : but be it obferved, that cutting off, from year to year, the thoots that are produced from the fpurs, increafes the canker, till large protuberances, like wens, are formed on the branches, becoming very unfightly; and thefe occafion them to produce only fmall and ill-flavoured fruit, at a great diftance from each other (See Plate IV. Fig. 2.) When this is the cafe, the method I purfue is, to head the trees down as before directed,

If the young hoots are properly trained, they will produce fruit the following year; and in the fecond year they will produce more and finer fruit than a young tree that has. been planted ten or twelve years.

It has been a general complaint, that Heart Cherries are bad bearers when trained up as wall-trees; but, by pruning them as Duke Cherries, I have brought them to bear in the fame manner: that is, I leave a great many fore-right thoots in Summer, and tuck them in with fome fmall rods run acrofs under the adjoining branches, to keep them clofe to the wall, and prevent them from being broken by the wind, and from looking unfightly.

Never make ufe of the knife in Summer*, if it be poffible to avoid it, as the thoots die from the place where they are cut, leaving

* As Morello Cherries bear their fruit on the fecond year's wood, from two to five in a clufter, and not on fpurs as other Cherries do, the ftrongeft and cleaneft wood fhould be kid-in at full length in the Summer, and all fuperfluous hoots be rubbed off, leaving a 
leaving ugly dead ftubs, which will infallibly bring on the canker. Thefe thoots may be cut in the Spring to about a couple of eyes, as Duke Cherries, which will form a number of flower-buds, as appears in PLATE IV. Fig. I. Fig. 2. is an old branch, to thew the manner in which the fpurs are formed when the old method of pruning is followed, and the barren unproductive fate of the tree.

As Cherries are a very confiderable article of traffic in the London markets, and the markets of moft towns throughout the kingdom, employing fuch a great number of people during the Summer feafon in gathering, carrying to market, and felling them, the raifing of them is certainly worth any gentleman's while, efpecially as the trees may be rendered ornamental as well as profitable, by planting them in thrubberies, \&c.* Gentlemen of fmall fortune, who are at a great expence with their gardens and plantations, may in a great meafure reimburfe themfelves by felling their Cherries and other fruit (for which there will be plenty of chapmen), and thus enjoy at an eafy rate the pleafures of a rational and ufeful recreation.

In all parts of the country, there are perfons employed in collecting fruit for the Markets, and to hawk it about from place to place; and furely it is much better to fell it to them, than to let it rot on the ground, or be devoured by birds and infects.

regular fupply to fill up the walls. They fhould be pruned and nailed at the fame time with other Cherries, either in Autumn or in the month of March; but we prefer Spring pruning.

* At Afhted-park, the feat of Richard Bagot Howard, Efq. near Epfom, there is a Cherry-tree between fifty and fixty feet high; and, at four feet from the ground, nine feet fix inches in circumference. This tree, with many others of the fame kind, was planted feveral years after the Chefnuts mentioned in Chap. XX.

When 
When Cherry-trees begin to produce fpurs, cut out every other thoot to make the tree throw out frefh wood: when that comes into a bearing ftate, which will be in the following year, cut out the old branches that remain; by that method you will be able to keep the trees in a conftant ftate of bearing, taking the fame method as before directed with the foreright ihoots.

Great care thould be taken to rub off many of them in the month of May, leaving only fuch a number as you think will fill the tree. By fo doing your trees will continue in a fine healthy ftate, and not be in the leaft weakened by bearing a plentiful crop of fruit. The reafon is obvious : the great exhalation which would be occafioned by the fun and air in the common mode of pruning is prevented, by the Compofition keeping-in the fap which nourithes the branches and fruit.

I cut fome trees, as directed above, more than twelve years ago, that are now in as good a ftate of bearing as they were in the third year after the operation, and likely to continue fo for many years.

In 1797, I pruned fome very old trees in the month of May, which were left, to thew the old method of pruning; $I$, at the fame time, cut fome branches of the fame trees according to the new method, to thew the difference of the fruit, which was taken by all who faw it for a different fort of cherry. The Cherries from the old fpurs were not half the fize of the others, and were at leaft three weeks later.

I am forry to fay, that many who have feen the improved ftate of the fruit-trees in Kenfington Gardens fill have their own managed according to the old method of pruning. Several, however, have adopted the new method with great fuccefs. One gentleman in this neighbourhood, by renovating thirtym 
thirty-nine old Morellos planted on a North wall 176 yards long, and ten feet high, was in a few years able to fell yearly, on an average, from thirty to forty pounds worth of fruit produced from them, befides fupplying his own family. In fome years the Market-Gardener who fold them allowed him three thillings per pound weight.

A row of Dwarf Cherry-trees that ftood againft an old paling in Kenfington Gardens, with an old thorn hedge at the back of it, (which every year fo infected them with a blight, accompanied by an immenfe number of caterpillars and other infects, that even in a fine year we could not gather cight bakkets from the whole row) became fo fruitful after the hedge and paling were removed, that we gathered forty-two pounds a-day for fix fucceffive weeks, befide what the birds, wafps, and fies deftroyed.

This eftimate is within the bounds of truth; and I mention the fact to ftimulate Market-Gardeners and Farmers, who have large orchards and gardens, to exert themfelves in trying every method, however unimportant it may at firft appear, to improve and render them more fruitful.

The Duke and Heart Cherries from thefe trees were as fine as any that were produced from wall trees; and, as they are much more produetive, I have been induced to take up many of the old renovated trees from the walls, and plant them out for dwarf ftandards, fupplying their places with Pears, Plums, Peaches, \&zc.

In all old gardens and orchards throughout the kingdom, and particularly in Kent, whence the London Markets are chiefly fupplied with Apples and Cherries, the greater part of the old trees will hardly bear fruit fufficient to pay the expence of gathering it; but if the above method of pruning, 
ning, \&c. were practifed, the owner would foon find his account in it, and be amply repaid for his trouble: The fruit would be much finer, and would have five times the quantity that the trees produce in their prefent condition; the trees would be more fightly, and always keep in a flourithing and bearing itate.

When old ftandard Cherry-trees become decayed and hollow, I would recommend heading them down, as directed for wall-trees and dwarfs. Scoop out all the rotten, loofe, and decayed parts of the trunk, till you come to the folid wood, leaving the furface fmooth; then ufe the Compofition as hereafter directed. 


\section{CHAPTER VI.}

OF APPLES.

Different Sorts of Apples defcribed-Of Heading Apple trees-OF: Espaliers and Drurfs-Grafting old Apple Trees; and of the Advantage of ufing the Compofition in that Operation.

LINN AUS has joined the Pear, the Apple, and the Quince: together, making them all of the fame genus, and has reduced all the varieties of each to one fpecies. They belong to the Twelfth Clafs, Icofandria Pentagynia.

The fpecies are,

I. The Wild Apple: with a very. four fruit, commonly. called Crab..

2. Wild Crab of Virginia, with a fweet-fcented fower.

3. The Dwarf Apple, which is rather a hrub than a tree; commonly called Paradife Apple... 
$I$, hall firft give a Lift of the beft Apples that have been introduced from France.

1. The Rambour is a large fruit, of a fine red next the fun, and ftriped with a yellowifh green. It ripens about the middle of Sepiember.

2. The Corpendu, or Hanging Body. This is a very large Apple, and has a red caft on the fide towards the fun, but is pale on the other. It takes its name from always hanging downwards; and ripens in September.

3. The White, or French Rennet, is a large fruit, of a yellowilh green colour, with fome gray fpots. It has a fugary juice, and is good either for eating or baking.

4. The Rennette-Grife is a middle-fized fruit, of a gray colour next the fun: it is a very good juicy Apple, of a quick flavour, and ripens atout the latter end of October.

5. Pomme d'Api is much valued for its colour, being of a bright red. The tree is a good bearer, and the fruit is not fubject to be thaken by high winds. This fruit fhould be fuffered to hang on the tree till October or November, if the froft do not fet in. It comes into eating in February and March, and keeps long; but is more admired for its beauty than its flavour.

6. Le Calville d'Automne, the Autumn Calville. This is a large fruit, of an oblong figure, and of a fine red colour toward the fun. The juice is vinous, and much efteemcd by the French.

7. Fenouillat, ou Pomme d'Anis, the Fennel, or Anife Apple, is a middle-fized fruit, of a gray culour; the pulp is tender, 
tender, and has a fpicy tafte like anife-feed. It ripens in September, October, \&c.

8. Pomme Violette, the Violet Apple, is a pretty large fruit, of a pale green, ftriped with deep red towards the fun. It has a fugary juice, and a flavour of Violets, from which it: takes its name. It ripens in October, and continues in eating: till February.

The forts above: mentioned are what have been introduced from France; but there are not above two or three of them that are much efteemed in England, viz. the French Rennet, the Rennette-Grife, and the Violet Apple; the others are mentioned for the convenience of thofe who wifh to have great variety.

I Shall now give a Lift of thofe Sorts of Apples rehich are moft efteemed in England.

9. The Juneting, or Jenneting, is a fmall yellowifh Apple, red on one fide. It is a pretty fruit for early variety, and ripens about the latter end of June and beginning of July.

Iо. The Codlin is generally the firft Apple that is brought to market. This fruit is fo well known, that it needs no defcription. It is in eating from July to December; and is good either for baking or boiling.

1. The Margaret Apple is a fine and beautiful fruit, yellow ftriped with red, of a delicate tafte, fweet fcent, and is generally eaten off the tree. It is ripe in Augunt.

12. The Summer Pearmain is friped with red next the fun; the flem is foft, but foon turns mealy; fo that it is not much efteemed. It ripens in Augutt and September.

I 2

I3. The 
13. The Kentifh Fill-Banket is a fpecies of Codlin, of a large fize, and is generally ufed for baking. It is in eating from Auguft to Oetober.

I4. The Tranfparent Apple was introduced from St. Peterfburg; but is more curious than uieful; a tree or two, therefore, will be fufficient for a garden. It ripens in September and Oetober.

5. Loan's Pearmain is a beautiful fruit; the fide next the fun is of a fine red, and the other fide ftriped with the fame colour; the flefh has a vinous tafte, but foon grows mealy, which leffens its value. It ripens in September and October.

16. The Quince Apple is feldom larger than the GoldenPippin, and the fide next the fun is of a ruffet colour. This is an excellent Apple for about three weeks or a month, and ripens in September.

17. The Nonfuch is a good bearer, and very fit either for the table or kitchen; the cooks, however, complain that it makes but a very fmall proportion of fauce. It is ripe in September and Octoher.

I8. The Golden Rennet is too well known to nced any defcription; it ripens about Michaelmas, and will continue good a month.

19. The Aromatic Pippin is a very good Apple, of a bright ruffet next the fun; and the flefh has a fine aromatic flavour. It ripens in Oetober.

20. The Herefordthire Pearmain, or Winter Pearmain, is of a fine red next the fun, and friped with red on the other fide; the fleth is juicy and ftews well. It is fit for ufe in November and December.

2I. The Kentifh Pippin is a handfome fruit, of a pale green colour, ard the flelh full of a quick acid juice. This is 
good kitchen fruit; it ripens in November, and will keep till February.

22. The Holland Pippin. This fruit is larger than the former, the colour darker, and the flen juicy. It ripens in Oclober, will keep long, and is a good kitchen Apple.

23. The Monftrous Rennet is a very large Apple, turning red towards the fun, and of a dark grcen on the other fide. It is generally preferved on account of its magnitude, as the flem is apt to be mealy. It ripens in October.

24. The embroidered Apple is pretty large, and the fripes of red very broad, from which circumftance it takes its name. It is commonly ufed as a kitchen Apple, and is ripe in October.

25. The Royal Ruffet, or Leather Coat Ruffet, is a large fruit, and one of the beft kitchen Apples that we have. It is alfo a pleafant eating Apple, and a great bearer; and is in ufe from October to April.

26. Wheeler's Ruffet is of middling fize, the flefh firm, and of a quick acid flavour; it is an excellent kitchen fruit, and will keep long. It ripens in Oetober.

27. Pile's Ruffet is a very firm fruit, of a harp acid flavour, but is much efteemed for baking. It ripens in October, and will keep till April.

28. The Nonpareil is a fruit defervedly valued for the brifknefs of its tafte. It is feldom ripe before Chriftmas, and, if well preferved, will keep till May. This is juftly efteemed one of the beft Apples that have been yet known.

29. The Golden Pippin is well known; and the French own it to be of Englifh origin. It is almoft peculiar to England; for there are few countries abroad where it fucceeds well. It is yellow as gold; the juice is very fweet; the 1 kin (efpecially 
(efpecially where expofed to the fun) is often freckled with dark yellow fpots. It is certainly the moft antient as wcll as the moft excellent Apple that we have. It ripens in October, and will keep through the Winter. There are feveral varieties of this fruit.

$3^{\circ}$. The Pomroy, or King's Apple, ripens nearly as foon as the Juneting; and, though not fo beautifully coloured, is larger and much better tafted.

31. The Red and White Calville are good Apples, of a vinous tafte. Some have a red, and fome a white pulp; and the white is reckoned of a mort delicious tafte. They are in eating in September and October.

32. The Kirton, or Crack'd Pippin, is a good Apple for the table. It ripens in September and Oetober.

33. The Ribfton Pippin* is a fine Apple from Ribfton Hall, near Knarefborough in Yorkfhire. It is a little ftreaked with red towards the fun, and yellow on the other fide. It is one of the beft Apples for eating and baking, and continues. in ufe from the end of Oetober till April. It bears very well. as a dwarf, and no garden thould be without it.

34. The Margill is an excellent Apple, and continues in ufe from November till the latter end of March. It is often fold in the London Markets for a Nonpareil.

35. Kirke's Scarlet Admirable, a good Apple for baking, and of a beautiful fcarlet colour, is. in eating about the month of January.

36. The French Crab is good for baking; and, when it is a favourable Seafon, will make a pretty good thow at the table. It keeps the longeft of any Apple that we know, being in eating from April to Chriftmas.

* The firft tree of this fort was found growing in Sir Harry Goodrick's Park. 
37. The Pomme Gree*, a fine Apple from Canada, is of a Alattih form, and ruffet colour, ftreaked beautifully with red. It ripens late and keeps till March.

38. Sykehoufe Ruffet, a fine eating Apple, from Sykehoufe, in Yorkthire.

39. The Godolphin Apple is a very handfome large fine fruit, Rreaked with red on the fide next the fun, and of a yellowith colour on the other fide. It is in eating from the latter end of September to December. I found this Apple growing in the garden of the late Lord Godolphin, in St. James's Park; and have given it the name of the Godolphin Apple, as I have not been able to find it in any Catalogue.

40. Pearfon's Pippin is a nice Apple, about the fize of a large Golden Pippin, of a yellowifh colour, and the form a little flat. In Devonfhire, they put thefe Pippins into the oven juit after the bread is drawn, laying a weight over them to flatten them, in the fame manner as they do the Beefin in Norfolk, and bring them to table as a fweetmeat.-I brought fome cuttings of this Tree from Nutwell near Exeter, which I grafted on fome trees in Kenfington Gardens.

41. The New-Town Pippin is a fine Apple in a good feafon; but feldoms ripens with us. It is held in great efteem in America.

42. Fearn's Pippin is of the fhape and fize of a Nonpareil. It is of a beautiful fcarlet colour next the fun, and of a golden yellow on the other fide. It makes a fine fhow at table, and will keep till the latter end of February.

* The Pomme Gree was introduced into this country by Mr. Alexander Barclay, of Brompton, well known for his ingenuity in bleaching of wax. He is a great lover of horticulture, and has raifed feveral new forts of Goofeberries from feed. 
43. Hay's fine-large baking Apple.

44. Queen's Apple is a beautiful fruit, red towards the fun, and of a fine yellow on the other fide. This is: a very fine Apple; in my opinion, next in perfection to the Golden Pippin, and about the fame fize. It is in eating from November to the end of March.

The above are the beft Apples that have come to my knowledge; but, for the convenience of thofe who are fond of great variety, I thall add a few, with their characters, from the Catalogue of Meffrs. Anderfon, Leflie and C๑. Nurferymen at Edinburgh; and alfo a lift collected from the Catalogues of the mont eminent Nurferymen in the neighbourhood: of London, and other parts of England.

Van Pippin, firtt ripe, little flavour, of Dutch origin.

Orzelon Pippin, a fmall early yellow Apple.

Gogar, or Stone Pippin, good, and will keep till May.

Whitemore Pippin.

Paradife Pippin, a beautiful long Apple, but foon grows: mealy.

Thorle Pippin, a pretty flat early Apple of great beauty.

Orange Pippin.

Dalmahoy Pippin.

Hamilton Pippin, good.

Bridgewater Pippin, for kitchen ufe:

Carberry Pippin, very good.

Lipbon Pippin.

Commiffary Pippin.

Crafton. Pippin, an Irifh deffert Apple, and much recommended.

Lufnefs Pippin. 
Balgown Pippin, is a true Golden Pippin; but by foil and culture rendered larger.

Scarlet Rennet, beautiful, but does not keep long.

Striped Nonpareil, a new fruit, the wood of which is Atriped.

Dutch Pearmain.

Royal Pearmain, a beautiful large Apple.

German Pearmain.

White Pearmain.

Summer Leadington. The Leadingtons are all of Scotch. production, and excellent baking Apples; but are foon apt to fpoil, except the Grey.

Large Stoup Leadington.

Scarlet Leadington.

White Leadington.

Grey Leadington. This is among the beft of our Scotch Apples, and keeps well, but of little beauty.

Royal Codlin, a large fine fruit.

Carlifle Codlin, much efteemed in the North of England for baking.

Summer Queening.

Winter Queening.

Summer Teuchet Egg, a fmall early Clydefdale Apple, of a reddith yellow colour.

Winter Teuchet Egg.

Sweener's July-Flower, good.

Ephrow, or Lady Apple, a very good keeping Apple.

Rofe Apple, or Greater Api, a French Apple, of fweet tafte and great beauty.

Wine Apple, one of the beft Scotch Autumn Apples. Golden Monday, or Pear Ruffet, good and beautiful. 
Yorkihire Green, for baking.

Strawberry, very good.

Summer Marygold:.

Fulwood, keeps long, fit only for baking,

Lady Wemyfs.

Purfemouth, well flavoured, but dry; a fine orchard: Apple.

Naked Apple, very good and keeps long; a Clydefdale Apple.

Red Ruby, an Orchard Apple:

Jerufalem Apple, is red all over, and has a: firm pulp, bur: little tafte..

Queen of England:

Dutchefs of Hamilton.

Salmon Apple, bright red and yellow colour, brifk juice, and keeps many months.

Whifteberry, very good.

Harvey Apple, from Cambridgefhire:

White Apple of Hawthornden, an orchard Apple.

Carfe of Gowrie,

Long Apple of Garron,

Winter Eli,

Summer Eli,

Pigeon Apple, or Pigionette, a French deffert Apple.

Tower of Glammis, an orchard Apple.

White Apple of Moncrieff, do.

Partridge Apple, a good fort for kitchen ufe 
Thofe in the following Lift marked thus*, are moft efteemed for eating raw; thofe $\uparrow$, for baking or boiling; and thofe $\begin{aligned} & \text { t, for } \\ & \text { f }\end{aligned}$ making of Cyder. The Words in Italick are names by whtich the preceding Fruit is frequently known.

* Acklam's Ruffet. Aged Pippin.

Aromatic Broading.

Summer Broading.

Autumn Pearmain.

$\uparrow$ Barcelona Pearmain.

+ Baxter's Pearmain.

$\uparrow$ Beaufin.

Lincolnfbire Beaufin.

rorkfbire Beaufin.

Norfolk Beaufin.

Beauty of Kent.

Belle Gridelin.

Beft Pool.

Black Pippin.

‡lack Moor.

Bontradue.

Braddock's Seek no further

+ Cat's Head.

* Cawood Timely.

* Chardin's Sans-pareil.

Chefter Pearmain.

+ Cockajee or Coccagee.

+ Contard.
Cotton Pippin.

Covadies.

Darling Pippin.

Derbyfhire Crab.

Devonhire Buckland.

Double-bloffom Scarlet Crab.

Dowfen's.

Dutch Paradife.

* Early Nonpareil.

$\ddagger$ Everlafting Hanger.

† Eyer's Greening.

t Fox Whelps.

Franklin's Golden Pippin.

Frank Rambour.

Frazer's.

French Pippin.

French Paradife.

† Gennet Moyle.

Golden Doucet.

Golden Mundi.

Golden Noble.

Golden Luftre.

* Golden Pearmain.

Golden Ruffet.

K 2

Gray 
Grey Noble.

Gray's Pippin.

† Green Blundrel.

+ Green Pearmain.

Hall Door.

Havers's Monfter.

$\ddagger$ Hertfordfhire Under-leaf.

Hollow-crowned Pippin.

* Hubbard's Pearmain.

Rufet Pearmain.
Mansfield Tart.

+ Minehall.

Neal's Summer Kentiffi.

New York Pippin.

New England Pippin.

Norfolk Paradife.

Norfolk Storing

Nutmeg.

Old Pearmain.

Orgeline, or Orjeline:

Hughes's New Golden Pippin.Oxford Oak Peg.

$\ddagger$ John.

Deux Ann.

July-Flower.

June Keeping.

Kipling's Pippin.

King of the Pippins.

Kirke's. Incomparable.

+ Kitchen Rennet.

Lady's Finger.

† Lancalhire Houfewife.

Large Yellow Pippin.

* Large Golden Pippin.

Baker's Golden Pippin.

Large Apple Williamfon.

Lawman's.

Lemon Pippin.

+ Lincolnfhire Rennet.

London Pippin.

Fize Crowned Pippin.

Lord Inay's Pippin.

\section{Oaken Pin.}

* Oxhead Pearmain.

Earl of Yarmoutb's Pearmain.

Pic Pie.

Pine-Apple Ruffet.

Pipy Ruffet.

* Pomphilia.

Queen's.

Queen's Pearmain.

Red-flefhed Beaufin.

Red Streak.

Red Vacan.

Ronald's Queen Charlotte.

+ Robine.

+ Royal Wilding.

Scarlet Pearmain.

Sheppard's Ruffet.

Siberian Crab.

Sir Charles Wagers.

Skerm's Kernel. 
Spencer's Pippin.

Spice Apple.

Spit.

Stout Buckland.

+ Striped Beaufin.

Stubbard.

\$ Styre.

+ Summer Rediftreak.

Summer Pippin.

Summer Ruffet.

† Summer Colman.

Summer Majetin.

Tankard Apple.

Ten Shillings.
Tom Two Years Old.

† Tranfparent Codlin.

Virgin.

* White Pippin.

White four.

Welch Lemon Pippin.

Whykins's Pippin.

Wine fop.

+ Winter Reditreak,

+ Winter Colman.

+ Winter Broading.

Winter Majetin.

\$Woodcock's.

Yellow Buckland.

N.B. The Siberian Crab and the Double bloffom Crab are good for preferving.

Surts of Apples proper for a Small Garden.

The Juneting; Golden Pippins; Nonefuch; Ribftone Pippin; Nonpareils; Queen's Apple; Sykehoufe; Golden Rennet; Aromatic Pippin; Grey Leadington; Scarlet Pearmain; Lemon Pippin; Pomme Gree; and French Crab; different forts of Ruffetins and Codlins, for baking.

I have taken all the pains that I could to afcertain the real names of the beft Apples; but the varicties are almof infinite: it is, therefore, hoped that if the fame Apple fhould in fome few inftances be found under different names, it being 
being almoft impoffible, amid fuch a variety, to avoid a miftake of that kind, the candid reader will have the goodnefs to view it with indulgence.

On the Choofing, Planting, Pruning, and Training, of Apple-Trees.

In choofing Apple-trees from the Nurfery, it may be fufficient to obferve, that they, as well as Apricot and Peach trees, thould have ftrong, ftraight, and clean ftems.

Sufficient inftructions have already been given for preparing the borders and planting the trees; which will alfo be applicable here. "The fame directions for heading muft be obferved, according to the feafon and time of the buds breaking forth, leaving the number according to the ftrength of each tree; cutting as clofe as poffible to the top bud, that the leading thoot may the more eafily cover the wound; and conftantly obferving to rub off all the buds that come up by the fide of the leading thoot, which would otherwife rob it of its nourifhment and ftrength, and fo prevent it from making a fine leader. [See Plate VI. Fig. I.] Remember to cut it annually to the length of from nine to eighteen inches, according to its ftrength, till the tree is got to that height to which you would have it run, and according to the extent of the ground; which height may be from eight to twelve feet. By thefe means the trees will throw out horizontal branches on every fide, and foon form handfome heads for Dwarfs.

I would advife not to fuffer the Dwarf-trees to run higher than twclve feet*; otherwife they will become naked at

* From 8 te i 2 feet will be found a very convenient height.

bottom, 
bottom, the fruit will be liable to be blown down, and the tops broken by high winds.

In heading old decayed Apple-trees, for the fake of fymmetry, it will be neceffary to cut at. the forked branches as near as can be to the upper fide of the fork, cutting them in a floping manner to carry off the wet; at the fame time rounding the edges.. You may begin at the lower branches, cutting juft above the lower fork; and, proceeding upwards, cut the reft of the branches from one to fix joints, or forks, according to their ftrength, till you have finifhed cutting-in the whole head. If any of thefe branches: thould have the canker, all the infected part muft-be cut out. When the tree is all prepared; apply the Compofition immediately, beginning at the top of the tree, and finifhing with the powder. of wood-afhes and burnt bones, as you defcend; which will fave it from being rubbed off during the operation; and the Compafition will prevent the fun and air from injuring the naked inner bark. A tree thus prepared will, in the courfe of three or four years, produce more and finer fruit than a. maiden tree that has been planted upwards of twenty years.

It is hoped that the above directions, if properly attended to, will be fufficient to enable any one to bring old decayed trees into a healthy bearing ftate. .

In large Orchards and Gardens, it may be neceffary, at firft, to head down only every other tree; cutting fome of the branches of the reft, which are in a decayed and cankery ftate and will bear no fruit. This will be preparing them to throw out new wood, and furnifh the tree much fooner with bearing branches. In fuch a feafon as the prefent (18:0), when there is ablight and general failure of crop throughout the kingdom, the operation may be performed in Summer, in 
the months of May, June, and July, and even fo late as Auguft, which will fave a feafon. As at this time Gentlemen are generally in the country, they could have the pleafure of feeing this performed under their own direction. I would, however, recommend the performing the operation as early as poffible; for by fo doing the wood will be the ftronger.

When the trees are become hollow, the fame method thould be followed as is directed for Plums; but by no means cut them down unlefs the tops are quite decayed; obferving to cut the loofe rotten wrood clean out of the hollow and other decayed parts, applying the Compofition. At the fame time remember to open the ground, and cut out all the rotten parts that may be found in the lower part of the ftem, together with all the decayed roots, which, if this be not done, will infallibly injure the freth wood and bark, and prevent a cure from being effected.

I would recommend heading down all Apple-trees that are much cankered and have ill-1haped heads; for by fo doing much labour will be faved, and the trees will amply pay the Proprietor.

Never thorten the young branches, except they are very thin, when it will be neceffary to do fo to fill the trees with young wood: nor prune any of the young thoots the fecond year (I mean the year after they are cut), as many of the eyes, almoft to the end of the fhoot, will, if it be ftrong, become fruit-buds next year; and fo on every year.

In the month of May in the firft year after the trees have been fo cut, it will be neceffary to go over them, and rub off, with your finger and thumb, all the fuperfluous young thoots; leaving from three to fix eyes on each hoot, according to the fize and ftrength of the branch cut. Thefe thoots will 
bear from three to four years; by which time they will be pretty much exhaufted by the great quantity of fruit produced from them : they fhould then be cut down to two eyes to produce new wood.

I always leave three different years' branches on the tree, when the firft thoot, $d$, is cut off at $e$, [See. Plate VI. Fig. 2.] You will obferve the next thoot, $f$, to be full of fruit-buds, if it has not been thortened; when it begins to grow weak, cut it off at $g$. The next cutting muit be at $i$, when the branch $b$ is tired of bearing. Proceed thus all over the tree with care and attention, and you will foon perceive the advantages of this method of pruning above the common mode; for by it you will be able to keep your trees in a conftant ftate of bearing, which, if left to nature, would only produce a crop of fruit once in two or three years. Always remember, when the fhoot that has done bearing is cut off, to apply the Compofition immediately, and to rub off the thoots where they are too numerous.

The beft time to prune Apple-trees is in the month of April, or in May, after the Peaches, Nectarines, and Cherries are pruned *.

The fmall thoots that crofs each other fhould be cut off, leaving the ftrongeft to fill up the tree, and make a fine handfome head. The fuckers that fpring from the root thould

\footnotetext{
* Soon after this pruning, about the middle of May, it will be proper to look over the trees, and to pick off any caterpillars that may be on them.

You will then fee what thoots are infected with the canker, and which might have efcaped your notice at the time of pruning; and, wherever you obferve the leaft appearance of infection, which may be known by the wood appearing of a brownifh colour, the fhoot muft be cut down till you.come to the found white wood.
} 
be carefully grubbed up, and the fide-thoots from the ftem cut off; for, if left to grow, they will greatly weaken the tree. The knobs, where old branches have been cut off, fliould alfo be pared away, leaving the furface of the tree as fmooth as poffible; then apply the Compofition; the young bark will foon begin to grow, and by degrees cover the old wounds with a frefh fmooth furface, and thus prevent the canker from gaining ground on the tree. I have feen fome old wounds of confiderable fize healed over in one year.

The trees which I pruned and dreffed, as above directed, in the courfe of the Summer I 795, are all perfectly cured, the wounds being filled up with found wood, and covered over with new bark: they all continue in a healthy ftate, and bear fine handfome fruit.

I have advifed feveral nurferymen about London, particularly Meffrs. Gray and Wear at Brompton Park Nurfery, Kenfington Gore, and the late Mr. Malcolm of Stockwell, to head down their Apple-trees after the feafon of drawing for fale is over.

Meffrs. Gray and Wear have headed a great many of fuch trees as were formerly thrown to the faggot-pile, and have been amply recompenfed for their trouble. Trees thus headed down, provided the ftems be ftrong, will, in the firft and fecond year, produce as much fruit as will refund the purchafe-money; befides, a great deal of time will be faved, which would be loft by planting younger trees.

If you can procure trees of the above defcription that have been headed down three or more years, they will be all covered with fruit-buds, and, if carefully taken up and planted in the Autumn, if the feafon proves favourable, you will have a tolerable crop of fruit the firit year. Such trees muft not be 
headed down like maiden-trees, but only thinned off where the branches run acrofs and rub againft one another, which fhould never be fuffered.

From what has been faid, I hope that gentlemen and others will not be blind to their own intereft; but that they will give the practice a fair trial, which, if properly executed, will not fail to turn out to their fatisfaction. Independent of the great advantage to be derived from the increafe of crops, inftead of decayed, mofs-grown trees, bearing only a few fmall hard and kernelly fruit, they will have the pleafure of feeing fine healthy clean trees loaded with large beautiful and well-flavoured fruit; which, to thofe who have a tafte for gardening and rural affairs, will be no fmall confideration.

I would never recommend training of Apple-trees as Efpaliers; for, by doing fo, the air is kept from the quarters of the garden; and by conftant pruning and cutting-off all the fide-fhoots which you cannot tie to the Efpaliers, you prevent them from bearing, and, moreover, bring on the canker.

When Dwarf trees have handfome heads, you will get more and much finer fruit from one of them than from fix Efpaliers; at the fame time a free air is admitted to the crops in the quarters, and the conftant expence of ftakes and labour, in laying the trees to the Efpaliers, is faved.

Efpaliers may be converted into Dwarf Standards by thortening the branches at different lengths, fo as that they may be able to fupport themfelves without the ftakes; but not to fhorten them all regularly; and if cut with judgment, as near to a leading thoot, or an eye, as poffible, they will in the courfe of two years form fine heads, and in the third year will bear fix times as much fruit as they did in their former ftate, and of a finer flavour. 
The fame method of pruning already laid down for Standard Apple-trees is alfo applicable to Efpaliers.

The borders where you make your croffings in gardens fhould be fix or eight feet broad at leaft, to let the trees fpread on each fide, at the diftance of twelve feet from tree to tree, and they thould be well trenched, two feet and a half deep at leaft. If there thould be gravel, or four clay, it muft be taken out, and good mould put in its place; leaving the ground as rough as poffible, for the froft and rain to mellow it. When you level the ground, it thould be done after rain: you may then fow fome fmall crops in the borders; fuch as Lettuce or Spinage, or Cabbage for tranfplanting; but let not any of the Braffica tribe come to full growth. Leaving Cabbage and Broccoli on borders, near fruit-trees, draws the ground very much, fills the borders with infects, and alfo prevents the Sun and air from penetrating into the ground.

When the Sun can have free acceís to the border, it adds much to the flavour of the fruit. If you can fpare the ground on the crofs-borders in Winter, it will be of great fervice to the trees to ridge it up as loofe as you can, and let it lie in that state all Winter, to mellow and fweeten.

If the foil be ftrong, I would recommend planting of Apple-trees that are grafted on Paradife Stocks; but if the foil be light, free Stocks will do much better.

When the ground is a ftrong clay or brick earth, mix it with old lime-rubbifh or coal-athes, ftreet-dung or fand: but what I ufe for the borders againft the walls, and which I prefer to every other manure, is a vegetable mould produced from leaves of trees, which may be obtained in the following manner:

Collect 
Colleet annually as many loads of leaves as you conveniently can, which make up into hot-beds for late Melons and $\mathrm{Cu}$ cumbers, and for early Potatoes, \&c. Firft plant the beds with early Potatoes; at the fame time fow Radifh and Lettuce fecds mixed together. When the Radilhes are pulled, thin the Lettuces, leaving a fufficient quantity for a crop; by the time the Lettuces are fit for cutting, the Potatoes begin to cover the bed. After the Lettuces are all cut, you Thould put fome of the leaf-mould clofe up to the ftems of the Potatoes, which will run very faft into the frefh manure, and produce a fine early crop. When you have dug up the Potatoes, take off all the fine vegetable mould till you come to the leaves that are not yet rotten; then with a fork turn up the leaves, adding lome frefh leaves at the fame time, which will caufe a frefh heat to come up in the bed; when this is done, put on the lights and keep them clofe for three or four. days: if the weather be fine and clear, there will, by that time, be a fine fweet gentle heat.

You may then fow or plant Melons or Cucumbers in the beds.

When the heat begins to decline, and the fruit to fwell, put a frefh lining of leaves, two feet and a half broad, round the beds. The beds may be broken up the fecond Winter; by which time you will find the top part of them rotted to a fine black vegetable mould, which will be the beft manure for the borders againit the walls.

A good coat of this manure once in two or three years will be fufficient for the borders where the wall-trees ftand, and much better than dung, which 1 by no means approve of for trees, unlefs it be perfectly rotten and mixed up with: mould. 
Some of the leaves will be found not quite rotten at the bottom of the beds; thefe may be mixed up with frefh dry leaves from the park, garden, \&c. and ufed for making new beds.

\section{Of Grafting old Apple-Trees.}

It frequently happens, that, through fome miftake or other, after waiting ten or twelve years for a tree to come into a bearing ftate, it is then found that the fruit is neither fit for the table nor kitchen; in fuch cafe, we always graft thein the following Spring, obferving to graft on the finelt and healthieft thoots, and as near as poffible to the old graft, and where the crofs-Thoots break out: by fo doing, you will have fome fruit the fecond year; and in the third, if properly managed, you will have as much as on a maiden-tree of fifteen years ftanding.

The canker, if any, muft be carefully pared off the branch, and the fcion mult be taken from a found healthy tree.

Whenever an incifion is made for budding or grafting, from that moment the canker begins. I would, therefore, recommend to thofe employed in budding or grafting, as foon as the incifion is made, and the bud or graft inferted, to rub in with the finger, or a brulh, fome of the Compofition before the bafs is tied on; then cover the bafs all over with the Compofition as thick as it can be laid on with a brulh, working it well in. If this operation be performed in a proper manner, and in a moilt feafon, it will anfwer every purpofe, without applying any grafting clay.

This I have frequently done, and found it fucceed perfectly to my wihes. Obferve, not to flacken too foon the matting which 
which is wrapped round the bud; for in that cafe you will find the incifion opened, which very often occafions the death of the bud.

If nurferymen and gardeners would give this method a fair trial, and ufe the fame Compofition as I ufe for curing defects in trees, inftead of loam and horfe dung (which binds fo hard as to prevent the rain and moifture from penetrating to the graft to moiften the wood and bark), they would find that the grafts would fucceed much better. The Compofition, for this purpofe, fhould be rather fofter than grafting-clay generally is; and, inftead of applying fo large a mafs as is generally done of clay, it need not, in mort cafes, be more than two or three inches in circumference. 


\title{
CHAPTER VII.
}

\author{
OF PEARS.
}

Different Sorts of Pears defcribed-Of Planting, Heading, Pruning, \& c.-Experiments on old Trees-A comparative Statement of the Produce of Pear-Trees, by the old and nere way of Pruning and Training-Of Trees headed downRemedy for the Canker, \& $c$.

THE Cultivation of the Pear is, undoubtedly, of confiderable antiquity; for Pliny mentions no lefs than twenty kinds, and Virgil five or fix.

Linnæus arranges Pears in the fourth fection of his twelfth Clafs, along with Apples and Quinces.

The Pear-tree comprehends feveral varieties, ripening in fucceffive order from July to Ostober. 
The Pears commonly propagated in England are as follow; viz.

I. The Little Mufk Pear, commonly called the Supreme. This fruit, when ripe, is of a yellow colour; the juice is fomewhat mukky; and, if gathered before it be too ripe, it is a good Pear. It ripens about the latter end of July, and continues good only a few days.

2. The Chio Pear, or Little Baftard Mufk Pear. This is pretty much like the other, but fmaller. The fkin, when ripe, has a few ftreaks of red next the fun.

3. The Green Chiffel, or Haftings Pear, is a middle-fized fruit; it always remains green, and is full of juice when ripe. It ripens in the beginning of Augurt.

4. The Red Mufcadelle is a large early Pear, of great beauty; the fkin is of a beautiful yellow ftriped with red, and the fleth has a rich flavour. This fometimes produces two crops in a year ; the firt about the end of July, and the fecond in September.

5. The Little Mufcat is a fmall Pear, the fkin very thin, and of a yellowith colour when ripe. This fruit has a rich munky flavour, but will not keep long. It is ripe about the beginning of Auguft.

6. The Lady's Thigh, commonly called in England Jargonelle, is of a ruffet green colour from the fun, but towards it inclining to an iron colour; the flefh is breaking, and has a rich mufky flavour. It is ripe abont the middle of Auguft.

7. The Windfor Pear has a fmooth kin, and, when ripe, is of a yellowifh green colour; the flefh is very foft, and, if permitted to hang but two or three days after it is ripe, grows 
mea'y and is good for nothing. It becomes ripe about the latter end of Auguit.

8. Jargonelle, commonly called Cuiffe Madame. This is certainly the true French Jargonelle; and the Pear which commonly goes by that name in England is the real Cuiffe Madame, or Lady's Thigh; and it is very probable that the names have been changed in coming to this country. This Pear is fomewhat like the Windfor; the kin is fmooth, and of a pale green colour. This is a plentiful bearer; but the flefh is apt to be mealy if it ftands to be ripe, which is about the middle of Auguft.

9. The Orange Mufk is of a yellow colour fpotted with black; the flen is munky, but very apt to be dry. It ripens about the latter end of Auguft.

10. The Great Blanquet, or Bagpipe of Anjou. This Pear has a fmooth fkin of a pale-green colour; the flefh is foft, and full of juice of a rich flavour. It ripens about the middle of Auguit.

II. The Little Blanquet Pear is much lefs than the former; of a pale colour, and the flem tender and full of a rich murky juice. It ripens about the latter end of Auguft.

I 2. The Long-ftalked Blanquet Pear has a very fmooth $\mathrm{fkin}$, white, and a little coloured towards the fun, and is full of a rich fugary juice. It is ripe at the latter end of Auguft.

I3. The Skinlefs Pear, or Early Ruffelet, is of a reddith colour, the fkin extremely thin, and the flerh melting and full of a rich fugary juice. It ripens in the latter end of Augurt.

14. The Mufk Robine Pear, or Queen's Pear (alfo called the Amber Pear), is fmall, and of a yellow colour when ripe; it has a rich muky flavour, and is a great bearer. This Pear ripens about the latter end of Auguft. 
15. The Mufk Drone Pear has a $\mathrm{k}$ in of a yellow colour when ripe, and a rich mufky tafte; but is apt to grow mealy if left too long on the tree. It ripens about the beginning of September.

16. The Red Orange Pear is of a greenifh colour; but the fide next the fun changes to a purple colour when ripe; the flefh is melting, and the juice fugary, with a little perfume. It ripens in the beginning of Auguit.

17. The Caffolette, or Green Mufcat, is a fmall greenifh Pear with fome fpecks in the fkin. It is full of a rich perfumed juice, and ripens in the latter end of September.

18. The Great Onion Pear, Brown admired, or King of Summer, is of a brownith colour next the fun, and is ripe in the beginning of September.

I9. 'The Mufk Orange Pear. The $\mathrm{k}$ in is green, and the flen melting. It ripens in the beginning of September.

20. Avorat, or Auguft Mufcat. This Pear has a fmooth Akin of a whitifh yellow colour; the juice is richly fugared and perfumed, and it is efteemed one of the beft Summer Pears yet known. It is a great bearer, and ripens in the beginning of September.

21. The Rofe Pear, or Thorny Rofe. This is thaped like the great Onion Pear, but much larger, of a yellowifh-green colour, but a little inclining to red next the fun. The flefh is breaking, and the juice muky. This ripens in the beginning of September.

22. Poire du Puchet. The flelh of this Pear is foft and tender, and the juice fugary. It ripens in the beginning of September.

23. The Perfumed Pear is of a deep red colour fpotted with $\mathrm{M} 2$ brown; 
brown; the flefh is melting, but dry, and has a perfumed flavour. It ripens in the beginning of September.

24. The Salviati Pear. This Pear is red and yellow next the fun, but whitith on the other fide; the fleth is tender, and the juice fugary and perfumed. It ripens about the middle of September.

25. The Rofe-water Pear. The $\mathrm{kin}$ of this Pear is rough, and of a brown colour, the juice is very fweet, and taftes like rofe-water. It ripens in the latter end of September.

26. The Ruffelet Pear. The flerh of this Pear is foft and tender, and the juice is agreeably perfumed. It ripens in the latter end of September.

27. The Great Mouthwater Pear. The flefh of this Pear is melting and full of juice. It ripens about the latter end of September.

28. The Prince's Pear has a highly-flavoured juice. It is a great bearer, and ripens about the latter end of September.

29. 'The Summer Bergamot. This is fometimes called Hamden's Bergamot. The flefh is melting, and the juice highly perfumed. It ripens about the latter end of September.

30. The Autumn Bergamot is fmaller than the former: the fleth is melting, and the juice highly perfumed. It is a great bearer, and ripens in the beginning of October.

3I. The Summer Bonchrêtien is very full of juice, which is of a rich perfumed flavour. It ripens about the middle of September.

32. Beurré Rouge (the Red Butter Pear). The flefh is very melting and full of a rich fugary juice. It ripens in the beginning of October, and, when firt gathered from the tree, is one of the very beft fort of Pears that we have. 
33. The Dean's Pear. The fleth of this Pear is melting and full of juice, which is very cold. This is a great bearer, and ripens in the beginning of October.

34. The Swifs Bergamot has a melting fleh and is full of juice, It ripens in the beginning of October.

35. The Long Green Pear. The flefh is melting and full of juice. It ripens in the latter end of October. This, by fome, is reckoned the fame with the Mouthwater.

36. The White and Grey Monfieur John. Thefe are the fame; the difference of their colour proceeding from the different foils and fituations wherein they grow, or the ftocks on which they are grafted. If this Pear be rightly managed, there are not many forts in the fame feafon to be compared with it. The flefh is breaking, and full of a rich fugared juice. It ripens in the latter end of October or beginning of November.

37. The Flowered Mufcat is an excellent Pear; the flefh is very tender, and of a delicate flavour. It ripens in November. $3^{8}$. The Vine Pear is of a dark red colour; the flefh is very melting, and full of a clammy juice. It comes into eating in November.

39. The Rouffeline Pear is of a deep-red colour, with fpots of gray; the flem is very tender and delicate, and the juice very fweet, with an agreeable perfume. It ripens about the latter end of October, but will not keep.

40. The Knave's Pear. The flefh of this Pear is fine and tender, and the juice very much fugared. It ripens in the latter end of October.

4I. The Marquifs Pear. If this Pear do not change yellow in ripening, it is feldom good; but if it does, the flefh will be tender 
tender and delicate, very full of juice, which is fugared. It comes into eating in November.

42. The Crafane Pear. The flefh of this Pear is extremely tender and buttery, and full of a rich fugared juice. It is the very beft Pear of the feafon, and comes into eating about the latter end of December.

43. The Lanfac, or Dauphine Pear. The flefh of this Pear is yellow, tender, and melting; the juice is fugared and a little perfumed. It is in eating the beginning of December. 44. The Martin See (the Dry Martin) is almof like the Ruffelet in thape and colour; the flefh is breaking and fine; and the juice is fugared, with a little perfume. It is in eating about the beginning of December.

45. The Amadot is rather dry, but high flavoured. It is in eating about the middle of December.

46. The Little Lard Pear is extremely fine; the flefh melting; the juice is much fugared, and has an agreeable muky flavour. It is in eating the latter end of December, and is efteemed one of the beft fruits in that feafon.

47. Louifbonne (the Good Lewis Pear). The fleth of this Pear is extremely tender, and full of a very fweet juice. It is in eating about the middle of December.

48. The Colmar Pear is very tender, and the juice greatly fugared. It is in eating about the beginning of January, and is efteemed an excellent fruit.

49. L'Efchafferie. The fleth of this Pear is melting and buttery; the juice is fugary, with a little perfume. It is in eating about the firft of January.

50. The Virgouleufe Pear is efteemed by fome as one of 
the beft fruits of the feafon*; the flefh is melting, and full of a rich juice. It is in eating about the firit of January.

51. The Ambrette is efteemed a very good Pear; the flefh is quite melting, and full of fweet perfumed juice. It comes into eating about the beginning of January.

52. Epine d'Hyver (the Winter Thorn Pear) has a very tender buttery pulp, of an agreeable tafte, with a fweet juice highly perfumed. It is in eating about the latter end of December.

53. The St. Germain Pear $\uparrow$ is a fine fruit and keeps long; the flefh is melting, and very full of juice, which in a dry feafon, or if planted on a warm dry foil, is very fweet. This is in eating from December till February.

54. St. Auftin. This Pear is pretty full of juice, which is often a little tharp; the flefh is tender, but not buttery. It is in eating in the latter end of December, and will continue good two months.

55. The Spanifh Bonchrêtien is a large fine Pear; the flefh is breaking, and the juice fweet. It is in eating in January.

56. The Wilding of Caffoy, called alfo the Small Winter Butter Pear, is a fmall fruit; the fleth is melting, and the juice very rich. It is in eating in January. This is an extraordinary good bearer. There was a tree of this kind at Campden Houfe near Kenfington, which generally produced a great quantity of fruit.

\footnotetext{
* In dry and cold feafons this Pear is very apt to crack, which greatly diminifhes its value.

+ This Pear, owing to the hot and dry Summer, has come into eating fix weeks fooner this feafon than I ever remember; and, of courfe, will be fo much fooner out than ufual. - It is to be obferved, that, in dry feafons, fruit fhould not be fuffered to fweat to long in the heaps as directed in the Chapter On Gathering and Laying.up Fruit; perhaps a fortnight will be long enough.
} 
57. The Martin Sire, or the Lord Martin Pear, is a good fruit; the fleth is breaking and full of juice, which is very fweet and a little perfumed. It is in eating in January.

5\%. The Winter Ruffelet. The flefh of this Pear is buttery and melting, and generally full of a fweet juice. It is in eating in the latter end of January.

59. Franc-real, or the Golden end of Winter, is only efteemed for baking.

60. The Brown Beurré. This Pear is of a reddith brown colour on the fide next the fun, and yellowith on the other fide. The flefh is melting, and full of a rich juice. It ripens in Oetober, and is juftly efteemed an excellent Pear.

6I. The Holland Bergamot, Amofelle, or Lord Cheney's, is a very good Pear, the flefh is half buttery and tender, and the juice is highly flavoured. It will keep from the end of January till April.

62. The German Mufcat is an excellent Pear; it is buttery and tender, and the juice is highly flavoured. It is in eating from February till April or May.

63. The Pear of Naples, or Eafter St. Germain, is half breaking; the juice is fweet, and a little vinous. It is in eating in March.

64. The Winter Bonchrêtien Pear is very large; the flefh is tender and breaking, and is very. full of a rich fugared juice. This is in eating from the end of March till June.

65. La Paftorelle is tender and buttery, and the juice fweet. This is in eating in March.

66. St. Martial, or the Angelic Pear. The flem of this is tender and buttery, and the juice is very fweet. This is in eating in March.

67. The 
67. The Wilding of Chaumontelle is melting, the juice is very rich, and a little perfumed. It is in eating in January.

68. The Brown St. Germain is a very fine high-flavoured Pear on Dwarfs and Standards, and comes in after the Wall St Germain. It continues in eating from December to the end of March.

69. Pear D'Auch was introduced by the late Duke of Northumberland. It much refembles the Colmar, but is fuller towards the ftalk. It is in eating from Chriftmas to April, and is, without exception, the beft of all the Winter Pears.

70. The Swan's Egg is a middle-fized Pear, in fhape like an egg; it is of a green colour, thinly covered with brown; the fle? is melting and full of a pleafant muky juice. It comes in eating in November. The tree is healthy, and bears well either as a ftandard or any other way.

71. The Bergamot de Pafque goes alfo by the following names, viz. the Terling, the Amofelle, the Paddington, and the Tarquin. This is a fine handfome fruit, green when gathered, and of a yellowifh or ftraw colour when ripe. It comes into eating about the month of April, continues till June, and makes a very handfome appearance at table *

72. The Golden Beurré is a very fine Pear; it is of a beautiful fcarlet colour next the fur, and of a gold colour on the other fide. The fleth is melting and the juice high-flavoured. It ripens in Oetober. This tree fucceeds beft on an Ean afpect, and a loamy foil. It is a plentiful bearer + .

* This Pear has come into eating above fix weeks fooner this feafon than in any other in my memory.

$f$ This Pear was introduced from Burgundy by the late Marhai Conway, and was firt 
A Selection of Pears, from the Catalogue of Meffrs. Anderfon, Leflie, and Co. Nurferymen, Edinburgh.

SUMMER PEARS.

Pear James; foon ripe, foon rotten; has a little flavour, and is the earlieft Pear that we have in Scotland.

Early Carnock; indifferent, of a yellow colour, and bright red towards the fun; makes a beautiful ftandard.

Lemon, Lady's Lemon, or Lady Lamont; indifferently good; principally valued for coming early, and being a good bearer. Green Pear of Pinkey; a fmall green Pear, nearly round, of a fweetifh tafte.

Forrow Cow, a Clydefdale Pear ; a large Pear with a thort ftalk; flat towards the eye; its colour red and yellow; its flefh tender and mulked.

Pear Sauch, a Clydefdale Pear, a big-bellied beautiful Pear; the tree large, a great bearer, and fit for an orchard; the Pear but indifferent.

Gray Honey, pretty good.

Green Orange Pear, or Orange Vert; a very good Pear.

Brute Bone, Chaw Good, or the Pope's Pear; indifferent.

Golden Knap, fuppoled Scotch, is a fmall Summer Pear of: tolerably good qualities.

Early Achan, an indifferent fruit, greatly inferior to the: Winter Pear of that name.

raifed, in this Country, at his feat of Park Place near Henley upon Thames, now the feat: of Lord Malmefoury. The above defuription was tranfmitted to me by Mr. Copland, his Lordfhip's Gardener.

Hanging 
Hanging Leaf; this is its name in Clydefdale; good and beautiful; almoft round; its colour red and yellow: a delicious fweetnefs is found in its tafte.

Scots Bergamot, a large good Pear, of a yellow and red colour; its flefh tender and juicy.

Longueville, very good, but a precarious bearer; fuppofed French, but not in their Catalogues by that name.

Mufked Boncrêtien, Gratioli, Cucumber, or Spinola's Pear ; a very good Pear, if grafted on a free ftock; its pulp is fomewhat between thort and tender, with a great deal of perfumed juice; its colour red on one fide, and white on the other.

Saffron Pear; a pretty large well-Thaped Pear, fit for an orchard.

\section{AUTUMN PEARS.}

Keather, a Clydefdale Pear, of middling fize, and oblong Thape, its juice agreeable.

French Carnock; tolerably good.

Elhin Haft, or Good-Man Pear; a long Pear, flat towards the cye; its colour green and yellow; its flem hard, dry, and fweet.

Drummond, or Late Scotch Carnock; very good, if eaten before it grows mealy; its colour a bright red and yellow:

Vicar, an oblong Pear, its colour yellow, red and ftriped, tender, fweet, and muked, but dry.

Royal Orange Bergamot; this differs from the Orange Bergamot in being yellower, and fometimes having a faint red on one fide.

Green Pear of Yair; fweet, juicy, and melting; of a moderate fize; takes its name from Yair, on Tweed-fide, where it was firft difcovered. 
Rob Hind; very indifferent.

Le Befideri, the Wilding of the foreft of Ileri in Bretagne: a yellowifh Pear of middle fize; indifferent.

Unicorn Pear; of a beautiful red and yellow. colour, but rather auftere in tafte.

\section{WINTER PEARS.}

Winter Achan, a Scotch Pear; among the beft early Winter Pears, and equal to moft of thofe of French origin.

Brier Burh, Scotch; a good pear, and will ripen in molt feafons ; it is a fmall Pear, of a firm fubftance and fweet tafte.

Brompton Park; a feedling: fent by Jeffery by that name.

Round Winter, a Clydefdale Pear; a very excellent Winter Pear, as defcribed in Dr. Gibfon's Fruit Gardener.

Poir Portrail, or Gate Pear; for baking.

La Double Fleur, or the Double Flowering Pear; a large flat beautiful Pear, with a fmooth $\mathrm{kxin}$, and blufh colour on: one fide, and yellow on the other; the beft Pear to preferve, taking a beautiful red colour from the fire.

In the following additional Lift thofe marked * are teft for baking: or ftewing, and theje + for making of Perry.

Ambrofia Pear.

Afhton Town.

Autumn Mufk Bonchrêticn.

Biflop's Thumb.

* Bloody Pear.
Brocas Bergamot.

+ Barland.

* Befideri.

Beaurré de Roi.

* Black Vear of Worcefter.

Britannia. 
MANAGEMENT OF FRUIT TREES, \&c.

Britannia.

Burdelieu.

Doyenne, or St. Michael.

* Catillac.

Eafter St. Germain.

Ganfel's Bergamot.

Gólden Beurré.

Gray Beurré.

Gray Goodwife.

Green Sugar.

Green Bergamot.

Huntingdon Pear.

$\uparrow$ Huffcap.

King's Catharine.

Lammas.
London Sugar.

Mufcat Almain.

Mufk Blanquet.

$\uparrow$ Oldfield.

Orange Bergamot.

Pear Piper.

Pyrus Pollveria.

Red Admirable.

Scotch Bergamot.

Seven Angled.

Silver Striped.

* Spanifh Red Warden.

t Squarh.

Striped Verte Longe.

White Beurré.

To thofe rutho have fmall Gardens, and room only for a fere Trees. I roould recommend the following as the moft. ufeful, viz.

Summer Pears. The Mufk Pear; the Green Chiffel; Jargonelle; Summer Bergamot; Summer Bonchrêtien. Autumn Pears. The Orange Bergamot; Autumn Bergamot; Ganfel's Bergamot; Brown Beurré; Doyenne, or. St. Michael; and Swan's Egg.

Winter Pears. Crafane; Chaumontelle; St. Germain; Colmar; D'Auch; L'Efchafferie; Winter Bonchrêtien, and Bergamot de Pafque.

The above will furnith a regular fuccefion of fruit. 


\section{Of the Management of Pear-Trees.}

It will be unneceffary to fay much here on the choice of young Pear-trees; as the rules already laid down are fufficient for that purpofe.

I would advife thofe who intend to plant Pear-trees, inftead of choofing young ones, to look out for the oldent that they can find in the Nurfery, and with frong ftems; to have them carefully taken up, with as much of the roots as polible, and carefully planted, after cutting in the roots a little, fpreading them as horizontally as you can. Then fill up all round the roots with light dry mould; forcing it in, about thofe which lie hollow, with a fharp pointed fick; filling the whole up to the top without treading the mould, till you have firf filled the hole with as much water as it will contain, leaving it a day or two until the ground has abforbed the water; then throw on fome frefh dry mould, and tread it as hard as you can; fill the hole up again with mould to within an inch of the top, and give it a fecond watering, leaving the mould about three inches higher than the border, to fettle of itfelf, and to receive the rain that falls, for at leaft a month. When the mould has become quite dry, you may tread it a fecond time; then make a large bafon all round the tree, and give it another watering; then mulch the top over with fome rotten leaves or dung, obferving to water the trees once a week in dry weather, and fprinkle the tops frequently with a pot, or hand-engine, to keep the wood from thriveling till the trees have taken frefh root.

When 
When you plant trees againft a wall, remember to let the ftem ftand floping towards it; the lower part of it thould be fix inches from the bottom of the wall, to give the ftem room to grow. If planted clofe to the wall at bottom, the fiem, in growing, will be confined on the back, and will grow flat, and be very unfightly. If any roots are in the way, to hinder it from being planted near enough to the wall; they. muft be cut off : at the fame time take care that the tree does not lean to either fide, but that, when viewed in front, it may appear perfectly upright. You will fometimes fee ftandards and half ftandards planted a foot or two from the wall, which gives them a very difagreeable appearance; fix inches. will be quite fufficient. Take care not to wound the ftem or: root of the tree in planting.

If the young trees have two ftems, always remember to cut off one of them, leaving the ftoutent and ftraighteft; obferving to plant that fide outwards which has mont buds. on it.

When the buds begin to break well, you may head the trees: to three or four eyes, to fill the wall with fine wood. You muft never head them afterward, except the leading thoot to fill the wall, obferving to leave the foreright fhoots to be pruned, as hereafter directed. I have had fome trees that had forty Pears on them the fecond year; while fome of the fame kind bore only eleven Pears the fourteenth year after planting, with the common method of pruning.

If you cannot get fuch old trees as recommended above, get the ftouteft and cleaneft of the one year's old after grafting.

If any of thefe trees get ftunted after a number of years, you have nothing more to do than to head them as hereafter directed; 
direeted, which will bring them into frem vigour and fruitfulnefs.

The method of pruning Pear-trees is very different from that practifed for Apple-trees in general. The confant practice has been, to leave great fpurs, as big as a man's arm, ftanding out from the walls, from one foot to eighteen inches and upwards. [See Plate VII. Letter C.] The conflant pruning inevitably brings on the canker; and, by the fpurs ftanding out fo far from the wali, the bloffom and fruit are liable to be much injured by the froft and blighting winds, and thus the fap will not have a free circulation all over the tree. The fap will always find its way firt to the extremities of the thoots: and the fpurs will only receive it in a fmall proportion, as it returns from the ends of the branches. The fruit ftanding at fo great a difance from the wall is too much expofed to the weather, and, of courfe, is liable to be hard, fpotted, and kernelly; as Letter D. PLATE VIl.

I have adopted the following method when the trees were all over cankered, and the fruit fmal!, and not fit to be fent to the table. I cut the tops off as near as porible to where they were' grafted; always obferving to cut as clofe to a joint or bud as poffible. The buds are hardly perceptible; but you can always know where the joints, or forks, are, by the branches breaking out of the fides.

Finding the Pear-trees in Kenfington Gardens in a very cankery and unfruitful ftate, in the years 784 and 5 , I took out the old mould from the borders againft the wal!s, and put in freth loam in its flead; at the fame time I pruned and nailed the trees in the common way, and left them in that ftate upwards of eighteen months, to fee what effect the freth 
mould would have on them; but, to my great furprize, I found that it had no good effect.

After I had tried the freth mould as above, I began to confider what was beft to be done with fo many old Pear-trees that were worn out. The fruit that they produced I could not fend to his Majefty's table with any credit to myfelf, it being fmall, hard, and kernelly. I thought it would be a great reflection on me as a profeffional man, that after $I$ had put his Majefty to fo great an expence, no advantage was likely to be derived from it. I faw that fome method muit be tried to reftore thefe old trees, or that next year they muft be grubbed up, and was loth to give them entirely up before I had tried fome experiments. I confidered, that it muft be between twelve and fourteen years before I could have any. fruit from young trees; and therefore determined to try an experiment, with a view to recovering the old ones.

I began with cutting down four old and decayed Pear-trees of different kinds, near to the place where they had been grafted: this operation was performed on the $15^{\text {th }}$ of May I 786. Finding that they put forth fine fhoots, I headed down four more on the 2oth of June in the fame year (for by this time the former had thoots of a foot long), which did equally well, and bore fome fruit in the following year. One of the firt four that I headed down was a St. Germain, which produced nineteen fine large well-flavoured Pears next year, [See Letter B. PLATE VII.] and in the third bore more fruit than it did in its former ftate when it was four times the fize.

I left feven trees upon an Eaft wall, treated according to the common method of pruning, which bore the following number of Pears upon each tree: 
Epine d'Hyver produced eighty-fix Pears, and the tree fpread fifteen yards.

A Crafane produced one hundred Pears, and the tree fpread fourteen yards.

Another Crafane produced fixteen Pears, and the tree fpread ten yards.

A Virgouleufe produced one hundred and fifty Pears, and the tree fpread nine yards.

A Colmar produced one hundred and fifty Pears, and the tree fpread nine yards.

Another Colmar produced feventy-nine Pears, and the tree fpread ten yards.

A L'Efchafferie produced fixty Pears.

Seven trees, headed down and pruned according to my method, leaving the foreright fhoots in Summer, bore as follows, in the fourth year after heading.

A Louifbonne bore four hundred and fixty-three Pears, and the tree fpread nine yards.

Another Louifbonne bore three hundred and ninety-one Pears, and fpread eight yards.

A Colmar bore two hundred and thirteen Pears, and fpread fix yards.

A Brown Beurré bore five hundred and three Pears.

Another Brown Beurré bore five hundred and fifty Pears.

A Crafane bore five hundred and twenty Pears.

A Virgouleufe bore five hundred and eighty Pears:

The branches of the four lant trees fpread nearly in the fame proportion as the firit three.

A young Beurré, the fecond year after heading, bore two hundred and thirty Pears; and a St. Germain four hundred. 
All the above trees ftood upon the fame afpect and the fame wall, and the fruit was numbered in the fame year. A great many Pears which dropped from the trees are not reckoned. The trees that were pruned according to the old practice covered at leaft one-third more wall than the others.

By the above fatement it appears, that the trees headed down bore upwards of five times the quantity of fruit that the others did; and it keeps increafing in proportion to the progrefs of the trees.

On the 2oth of June I headed feveral Standards that were almoft deftroyed by the canker; fome of them were fo loaded with fruit the following year, that I was obliged to prop the branches, to prevent their being broken-down by the weight of it. In the fourth year after thefe Standards were headed down, one of them bore two thoufand eight hundred and forty Pears. There were three Standards on the fame border with the above, two of which were St. Germains; the old. tree was of the fame kind. One of thefe trees*, twenty years old, had five hundred Pears on it, which was a great crop for its fize: fo that there were on the old tree, which had been headed down not quite four years, two thoufand three hundred and forty Pears more than on the tree of twenty years growth.

When the men numbered the Pears, there was near a barrowful of wind-falls at the bottom of the old tree, which were not included.

Plate VIII. is a correct Drawing of an old decayed Beurré Pear-tree, reftored from an inci and a half of bark, which now covers a wall fixteen feet high. In the year 1796, it

* This tree was about fix years old when I planted it fourteen years ago.

$\mathrm{O}_{2}$

bore 
bore four hundred and fifty fine large Pears, and has continued in a flourifhing ftate even fince. The letters $a, a, a$, reprefent the fruit buds for the prefent year; $b, b, b$, are thofe: forming for next year; and $c, c, c$, the old footftalks that bore the fruit latt year: the fmall buds are beginning to form, which produce fruit the fecond year; and $d, d$, are the foreright fhoots as they appear before they are cut, which muftbe at $e$, clofe to a bud, and floping towards the wall as much: as you can, leaving them as regular as poffible all over the: tree; you will then have a regular crop of fruit from the ftem to the extremities of the branches: but if this be not obferved, you will have hardly any fruit next year.

The following is the rnethod which I purfue in training trees that are cut near to the place where they were grafted.

Every year, in the month of March, I fhorten the leading; thoot to a foot or eighteen inches, according to its ftrength; this fhoot will, if the tree be ftrong, grow from five to feven feet long in one feafon; and, if left to nature, would run up without throwing out fide-fhoots. The reafon for thus thortening the leading thoot is, to make it throw out fide-fhoots; and if it be done clofe to a bud, it will frequently cover the cut in one feafon, leaving only, a cicatrix, as at $f, f, f$, in: Piate VIII. which thew every year's growth and cicatrix.When the thoots are very ftrong, I cut the leading thoot twice in one feafon; by this method I get two fets of fide. thoots in one year, which enable me the fooner to cover the wall. The firft cutting is performed any time during the Spring, and the fecond about the middle of June.

When you prune the trees, and cut the foreright rhoots, which fhould be done in February or March, always cut clofe to an eye or bud, obferving where you fee the greateft 
number of leaves at the lower bud, and cut at them; for at the footitalk of every one of thefe will be produced a flower bud. The fame will hold good in cutting the fuperfluous thoots on Standard Pears. You will have in fome forts of Pears, in a favourable feafon, from five to nine Pears in a clufter. This cutting fhould not be later than March, or the beginning of April, on account of the leading fhoot be-ginning to grow ; the next topping, when the leading fhoot grows quick enough to admit of it, thould be about the middle of June; and the length of the fhoots fhould be according: to their ftrength, having from three eyes, or buds, to fix on a fide.: Plate. VIII. will better explain the different years". growth, \&c. than I can do by words. The loweft $f$, is the place where we began to cut the top off; and $g$, the old de-cayed fump, with very little bark left.

The cankery part beginning to affect the new bark, I cut off all the canker at the bottom laft year, and plaftered the place with fome cow-dung mixed with wood-athes and powder of burnt bones, put into as much urine and foapfuds as would make it of the confintence of thick paint; this I laid on with a painter's brufh. After it had been applied about three hours, I patted it gently down, with my hand, clofe to the tree. By fo doing, I get rid of all the air bubbles that: may be under the Compofition, and make it adhere to the tree, preventing it from being wafhed off by heavy rains.

In the beginning of Augunt we horten the foreright thoots to about four inches long; by this time the fhoot will have: made its. full growth for the feafon, and will produce fine. ftrong eyes for the following year.

Such thoots as grow near the ftem of the tree, if any are wanted to fill up the wall, may be tucked-in as directed for

P.eaches. 
Peaches. [See alfo Prate VIII.] This will prevent them from looking unightly, and fave them from the fury of the Autumnal and Winter winds.

The tree above-mentioned had a decayed rotten root, the dead part of which I cut all away, till I came to the found wood. Whenever the trunk is hollow, you muft follow it under ground till you have cut out all the decayed parts and rotten roots; otherwife you will lofe the tree.

By proceeding according to the foregoing directions, the root will be renewed, while the tree is forming a fine handfome head. In the mean-time trench your borders, taking up all the old roots, and add fome frefh mould to them, if you can conveniently get it; if you cannot, remove all the four mould that is about the roots of the trees, and put in fome taken from the border, at a diftance from the wall; always remembering to lay the top fpit next to the roots of the trees; alfo, mix fome vegetable mould, from the Melon and Cucumber beds, with rotten leaves, as a manure for the borders.

1 have headed down many trees that had not this preparation; and yet they throve very well, but did not fend forth fuch fine roots and thoots as thofe that were fo prepared.

If the above directions be followed, you will get more Pears in three or four years than you can in twenty-five years by planting young trees, and pruning and managing them in the common way.

If you thould find, that, before the Pears arrive at half their natural fize, they get ftunted, after cold blighting winds, and frofty nights (fuch as we have had for feveral years paft in the months of June and July), I would recommend a new operation to be performed when the weather begins to grow mild. 
Take a tharp penknife, and with the point of it make an incifion through the rind of the Pear from the footitalk to the eye, in the fame way as you would fcarify a bark-bound tree, taking care to penetrate as little into the flefh of the Pear as poffible. At the fame time beat up fome frefh cow-dung with wood-afhes, and with your forefinger rub in a little of this Compofition where you made the fcarification; as the wound heals, the Compofition will be difcharged from the fruit; this will prevent the Pears from cracking and burfing, which renders them good for nothing. The forts that are mont liable to this diforder are, the Colmar, Virgouleufe, and Crafane.

I only recommend this operation for wall Pears. It may be thought by fome a troublefome operation. It certainly will take up fome time; but fure I am, that no gardener, who wifhes to have his mafter's table well fupplied with fine Pears during the Winter, will grumble at lofing a few hours fleep in a morning, or fpending an hour or two in an evening after his men have left work. It may, perhaps, prevent him from fpending his money and lofing his time in a public-houfe, or in fome triffing amufement to very little purpofe. At the fame time it will afford him fingular fatisfaction to find his handywork profper.

Refpecting the Diftance at which Pear-Trees flould be planted from each other againft Walls, and of the Breadth of the Bor... der's.

If Pears are grafted on free Stocks; fuch as Colmars, Pear D'Auch, Crafanes, L'Efchafferies, Virgonleufes, and Winter and Summer Bonchrêtiens, they Mould be planted at leaft 
twelve yards diftant from each other, fuppofing the walls to be from'twelve to fixteen fect high ; if they are only ten feet, fifteen yards will be little enough.

If Pears are planted on South walls, you may plant Vines, Peaches, Nectarines, or Apricots, between them, till the trees extend fo far as nearly to meet each other; you may then remove the Peaches, Nectarines, \&c. to any other fituation in the garden where they are wanted. If Pears are planted on Went walls, you may plant the fame fort of trees between them as on South walls; the fruit on a Weft afpeet will come into -ufe to fucceed that on the South. On an Eatt wall you may plant different forts of Plums and Cherries between the Pear-trees till they almont meet; then tranfplant the Plums and Cherries as Standards or wall-trees, as you fee fit.

The borders for Pear-trees in a large garden fhould not be leis than from ten to twenty feet wide, with a foot path about three feet from the wall, covered over at top with coal-athes, or road-fand, to make a dry walk for getting at the trees to cut and nail them, to gather the fruit, \&c.

The depth of the mould for Pear-trees thould never be lefs than three feet, laying the beft mould at top, to encourage the roots to come as near the furface as poffible. If the bottom be clay it will be very neceffary, once in every five or fix years, to open the ground round the roots of the trees, and cut off all the large ones that are inclining to run into the clay ; by fo doing, your trees will throw out freth roots that will run near the furface, provided the mould is good near the top of the borders.

You may have a crop of early Peas, Lettuce, or Spinach, or any other fmall crops, on the borders, during the Winter 
and Spring; but no late crops by any means. If the ground can be fpared, I would advife to have no Summer crops; but keep the borders hoed, in particular after rain; otherwife the ground, if a ftrong loamy or clayey foil, will be apt to crack in dry weather; but by frequent ftirring between wet and dry this will be in a great meafure prevented, and the Sun's rays admitted into the mould, which will greatly heighten the flavour of the fruit. When you can conveniently fpare the borders in Winter, they thould be ridged up to fweeten the mould; which you may very well do, if you fow early Peas on the fides of the ridges; which is by far the beft way to preferve the Peas from the froft, and to prevent them from rotting, which will fometimes happen, if the land be ftrong, before they begin to vegetate. Or, you may fow an early crop of Carrots or Spinach on the borders. 


\section{CHAPTER VIIL}

\section{OF VINES.}

Different Sorts of Vines cultivated in England-Of their Propagation-Experiments on Training and Pruning, with full Directions for the right Performance of both-Ufe of the Compofation in Pruning-Of Watering-Preferving Grapes from Flies, Wafps, and Birds-Of gathering Grapes, and keeping them in Winter:

THE Vine is a native of mort of the temperate parts of the world, and has been cultivated ever fince the flood. It belongs to the firft order of Linnæus's fifth Clafs, Pentandria Monogynia.

I thall here felect thofe Vines which are moft efteemed in this country, for the Hothoufe, Vinery, and the Natural WW all ; and give a thort defcription of each.

$$
\text { N. B. }
$$


N. B. The letter (h) diffinguiflies the proper forts for a Hothoufe, the letter (v) for a Vinery; and the letter (w) for a Common: Wall.

I.. The July Grape, or: Morillon Noir Hatif, is a fmall: round black berry of a fugary juice; and is principally: efteemed for being early ripe, which is in September. $v . w$.

2. The Royal Mufcadine; D'Arboyce, or Chaffelas Blanc; is an excellent Grape; the bunches are large, and compofed of round amber-coloured. berries of a rich vinous tafte: In a: fine feafon it ripens in September. $b_{0} v_{0}$.

3. The Malmfey: Mufcadine fomewhat refembles the preceding; the juice is very fweet, and of a high flavour. This: is a good bearer and a very fine Grape. $\omega_{.} v_{0}$.

4: The Black Mufcadine. This is a good bearer, and the berries are beautifully powdered with a bluifh bloom. $h . v$.

5. The White, or Common Mufcadine, by fome called the Chaffelas. This refembles the Royal Mufcadine, but the berries are fmaller; and, although it is not fo fweet as the Royal, it is the beft Grape that we have for a common wall, and a great bearer. $w$.

6. The White Mufcat of Alexandria, or Alexandrian Frontinac. The berries are oval, and the bunches long, This Grape has a rich vinous juice, and is efteemed an ex. ceeding good Grape for the Hothrufe. $h$.

7. The Red Mufcat of Alexandria refembles the former; only the berries are red. $b$.

P2: 8. The: 
8. The White Mufcat, from Lunel. This Grape has large oval berries of an amber-colour, and full of a vinous juice. This Vine is a plentiful bearer, and highly efteemed. $b . v$.

9. The Black Mufcadel has large oval berries of a black colour, and pleafant juice. $h$.

Io. The Red Mufcadel has large red berries of an oval thape, and ripens late. The bunches are very large. $b$.

I I. The Black Damafcus has large, round, black coloured berries; the fleth is rich, and well flavoured. This is an excellent late Grape. $h$.

I . The Black Grape from Tripoli has large black berries, and is an excellent Grape. $b$.

I3. The Black Spanith, or Alicant Grape. This Grape has black berries of a pleafant flavour. $b . v$.

14. The Black Grape from Libon. This Grape lias large round juicy berries, and the bunches refemble the Black Hamburgh. This is a good Grape. b. v.

I5. The Black Frontinac, or Mufcat Noir. This Grape has pretty large round berries, black when ripe, and covered with a mealy powder. It has a rich vinous juice, and ripens in October. $b . v$.

16. The Red Frontinac, or Mufcat Rouge, is a very fine Grape, and greatly efteemed: it has large brick-coloured berries, and the juice is of a highly vinous flavour. $v$.

I7. The White Frontinac, or Mufcat Blanc, has large bunches compofed of round berries. The juice of this Grape, when fully ripe, is exquifite. $b . v . v$.

18. Grizzly Frontinac has round berries, of a colour compoled of brown, red, and yellow. This Grape has an excellent flavour. $b \cdot v$. 
19. The White Sweet Water. The berry is large, of a white colour and very agreeable juice. This is efteemed an excellent Grape, and ripens in September. h. v. w.

20. The Black Sweet Water has a fmall roundifh berry of a fweet tafte; but, being apt to crack, is not in much repute. The birds are very fond of this Grape, which ripens in September. $v$. $w$.

2r. The Black Hamburgh. The bunches of this Grape are large, compofed of large oval black berries, of a pleafant fweet juice and vinous flavour. It ripens in November. $h . v$.

22. The Red Hamburgh has thin-Akinned berries of a dark red. They have a rich vinous flavour, and ripen about the fame time with the former. $b . v$.

23. The White Hamburgh. This Grape has large ovalthaped berries, and is a pretty good bearer. $b$.

24. The Small Black Clufter has fmall oval berries. The leaves are covered with a hoary down. This is a very pleafant fruit. $v$. w.

25. The Large Black Clufter is larger than the former, and has a very rough harh tafte. Mr. Speechly fays, that he had this Grape from Lifbon, and was affured that it is the Grape of which they make Red Port Wine. I have had the fame Grape eight or ten years. $v$.

26. The White Grape from Alcobaca. This Grape bears large bunches of white juicy berries. $v$.

27. The White Morillon has an oval-hhaped juicy berry. The leaves are downy on the underfide. $b . v$.

28. Early White Grape from Teneriffe. The berries are of a middling fize, and the fleth remarkably fweet and juicy. $v . w$.

29. The White Parfley-leaved Grape, or Ciotat. This Grape 
Grape has round berries, white, juicy, and fweet. There is as fort of the Parlley-leaved Grape with red fruit: $v$.

30. The White Corinth Grape has a fmall round berry. with a fine juicy flefh of an agreeable flavour: $v$.

31. The Aleppo: Grape has middle-fized berries, with $a$ juicy flen of a very fine flavour. This is a curious. Grape, frequently ftriped black and white. $h . v$.

32. The Red Grape from Syracufe. This is a: very. fine: large Grape. $h$.

33. Le Cour Grape, or Morocco Grape. This Grape has berries of a tawny colour, and is highly efteemed. $b$.

34. The Golden Galician Grape has large oval berries, of a yellow colour, and tolerable flavour. $h$.

35. The Black Raifin Grape. This fpecies has large black berries of an oval form: The $\mathrm{kin}$ is thick, and the flefth firm. $b$.

36. The White Raifin Grape refembles the preceding; only that the berries are white. $b$.

37. The Malvoife, fometimes called the Blue Tokay, has: fmall brownifh berries, powdered with a blue bloom. The: juice is vinous: $b . v$.

38. The Genuine 'Tokay is a white Grape, with a thin 1kin, delicate flefh, and agreeable juice. $b_{0} u_{0}$

39. The Lombardy Grape has fine, large, flame-coloured: berries full of a fine juice; and the bunches grow to a great: fize, frequently weighing more than fix pounds. $b . v$.

40. The Smyrna Grape. This has a large red berry of a very fine flavour, and is efteemed a very good Grape. $b$. v.

41. The Brick Grape, fo called from its colour, has fmall: berries, but the juice is fweet. $v$. $w$.

42. The Claret Grape has fmall black berries, with a blood. 
red juice; but the Grape is very harih, if not perfectly ripe. b.v.

43. The Syrian Grape. This has large, white, oval berries, with a thick $\mathrm{fkin}$ and hard flefh. It is a good bearer. $b$.

44. The Auverna, or true Burgundy Grape, fometimes called the Black Morillon, is an indifferent fruit for the table; but is efteemed one of the beft for making wine. $v$. $w$.

45. Cat's Grape. This Grape has fmall berries of a pale green colour. The fleth is foft and juicy, but of a very difagreeable tafte, unlefs quite ripe. $b . v$.

46. The Damfon Grape has very large berries of a purple colour. $b$.

47. St. Peter's Grape has a large oval berry, of a deep black colour when ripe; the bunches are large, and the fleth juicy; it ripens late. $\%$.

48. The Greek Grape. The berries are of a bluin white colour ; and it is efteemed a fine Grape. b. v.

49. The Black Corinth, or Currant, Grape, is a fmall roundih berry, generally without a Itone, of a deep black colour. It has a fweet juice, and ripens in October. $h . v$.

50. The Cornichon Grape has berries of a remarkable fhape, long and narrow, of a white colour, with a firm fweet Alefh. $b$.

51. The Red Chaffelas is very like the Chaffelas Blanc in fize and thape, but is of a dark red colour. It is a very good Grape, but ripens later than the white.

52. The New Mufcat of Jerufalem was introduced by Mr. Philip Miller, a Vine of which is now in the Botanic Gardens at Chelfea. It has large round berries of a red colour; fome of which I have, in fine feafons, feen as large 
as a goofeberry; but, as it does not ripen well on the natural wall in this country, it might be worth while to try it in a hothoufe, or vinery. It was introduced here about thirty-fix years ago. $h . v$.

53. The Black Prince. This has fine large berries, and the bunches grow to a large fize: I have had them, in a favourable feafon, on the natural wall, weigh a pound and a half. This Grape very well deferves a place in the hothoufe and vinery. It ripens on the natural wall * in October. Laft feafon I left fome of them on the Vines till the middle of November.

\section{To the foregoing may be added:}

Black Frankindale. Black Gibraltar. Black Mufcat of Alexandria. The Miller Grape. New White Sweet Water. Paffe Mufk. Pearl Mufcadine.

From the Red and White Conftantia is made the famous Conftantia Wine, fo called from a place near the Cape of Good Hope.

My worthy friend, Colonel Paterfon $t$, informs me, that

* The time of ripening refers to thofe on the natural wall; as on hot walls and in houfes it depends on the time when you begin forcing.

+ This gentleman is well known in the Literary World, by his Narrative of Four Journeys into the Country of the Hottentots, and Caffraria; from whence he fent a great many new plants and feeds to England. He alfo brought home with him fome curious thins; and good drawings of many plants, animals, \&c.

this 
this Vine, when tranfplanted to but a fmall diftance from that fpot, produces a very inferior wine. In his Narrative he fays, "Conftantia produces excellent wine, though the fituation is rather low. It is, however, preferable to all other parts of this diftrict; not only becaufe it is rather more elevated, but on account of the nature of the foil, which is a light fandy loam."

\section{Select Vines for a Small Garden.}

The White Mufcadine; White Sweet Water; Black Sweet Water; Large Black Clufter; Small Black Clufter; The Miller Grape.

St. Peter's, and the Black Hamburgh, will do very well in favourable feafons.

\section{Of the Propagation of Vines.}

The Vine is propagated by feeds, cuttings, and layers; and by grafting and inoculation.

When Vines are to be raifed from feed, it fhould be fown about the latter end of February, or beginning of March, in pots filled with light frefh mould, and plunged in a moderately warm hot-bed, gently fprinkling the mould from a watering-pot having a fine rofe. About fix or eight feeds, if good, will be fufficient for a pot* of forty or fixty to a caft;

for,

* In the vicinity of London, Pots are denominated by the number contained in what the Potters call a Caft.

They are delivered in at the price of from two fhillings and fourpence to balf a crown per Cait, which contains as under, viz. 
for, if fown too thick, the plants are apt to be drawn, and thereby become very weak. In dry weather, the pots thould be watered gently every day; but in wet or moift weather this may frequently be omitted, giving them fo much only as will keep the mould moift till the plants begin to vegetate. The proper time for watering is in the afternoon, when the fun is going off the frame. Obferve to thut the frame down immediately after watering; and if the heat be not too great, it may remain thut during the night. As the heat of the bed begins to decay, you muft add a lining of horfe-dung and frefh lcaves; which, when occafion requires, may be thaken up and repaired by adding fome frech leaves and dung to it, and thus keep up a proper warmth till the plants have got fufficient ftrength to do without any bottom heat.

About the latter end of Auguft it will be neceffary to take the lights off, that the plants may be hardened before winter, taking care to thelter them in frames covered with mats, which will prevent the froft in the latter end of October and beginning of November from injuring the tender thoots.

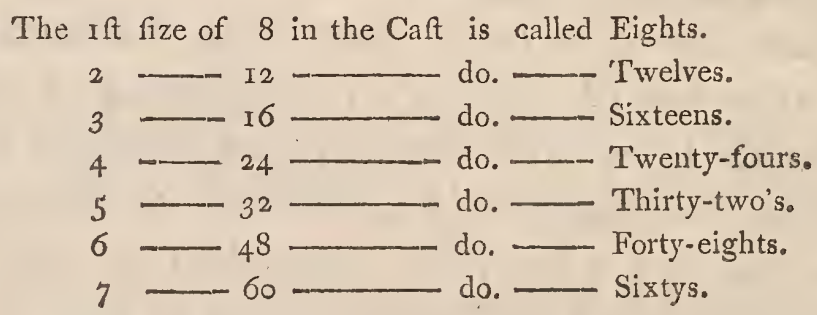

Pans for forced Strawberries, French-beans, \&c. are alfo fold by the Caft, and at the above price.

Pots larger than eights are generally made to order, and paid for according to their fize.

There are fome fmaller than fixtys, for feedlings and heaths.

When 
When the plants are about fix inches high, they fhould be tranfplanted fingly into deep forty-eights, filled with the fame fort of vegetable mould as is directed to be ufed for Vines; taking great care not to hurt the roots, nor to break the leaders; then plunge them again into the hot-bed: but if the heat of the old bed be too much decayed, it will be neceffary to have a new one prepared before-hand to receive the pots as foon as the plants are tranfplanted. If they grow vigoroufly, it will be neceffary to thift them into thirty-two's.

When the plants are above fix inches high, they mould be carefully tied to fmall rods, leaving only one ftem for the firft year. The rods thould be as high as the frames will permit.

When the leaves begin to drop, they chould be carefully picked off the pots, to prevent the plants from getting mouldy, which would very much injure them.

The plants hould be kept under frames, or put into the green-houfe, in hard Winters, to Thelter them from fevere frofts. In the Spring, about March or the beginning of April, if from feed ripened in this country, they may be planted out againft the walls where they are to remain; but, if from feed imported from Vine countries, I would advife not to plant above one or two againit the wall, or in the hothoufe, before you have obtained a fpecimen of the fruit, and be fatisfied that they are worth cultivating.

After they are planted, they fhould be cut at the third eye, if ftrong; but at the fecond, if weakly : at the fame time remember to rub off the lower bud with your finger and thumb, as hereafter directed.

If Vines are to be propagated from cuttings, they fhould be chofen from the fhoots that are beft ripened, and have the thorteft joints; always having one or two joints of the laft

$$
\text { Q } 2
$$


year's wood, cutting it perfectly fmooth and a little rounding: at the lover end, and as near to a joint of the old wood as poffible. The upper end thould alfo be cut fmooth and floping towards the wall; but if they are planted in beds or borders, let the cut always face towards the North. When cuttings are planted againft piers or walls, let it be at about a foot diftant from each other, accurding to the vacant fpace, and fo deep as to have the fecond eye level with the ground; remembering always to rub off the lower eye. By fo doing, if no accident happens to the top bud, there will be a thoot produced from each eye, with a little one under, which fhould always be rubbed off as foon as it begins to fwell; for if fuffered to grow to any confiderable fize you will be in danger of injuring the large one in rubbing the fmall one off. Remember alfo to pick off all the runners and fide-ihoots, as. before direeted, leaving only two thoots, which thould be trained at their full length. About January or February they may be pruned, leaving one or two eyes on each according: to. the ftrength of the thoot, which thould be managed as thall be more fully explained hereafter.

In the firtt year, efpecially if the Summer be dry, and proper attention be not paid to the watering of them, they will make but little progrefs; but in the fecond year you will. plainly difcern which is the ftrongeft plant, which, only fhould be left to fill up the vacant fpace on the wall: the reft fhould. be taken up and planted in other ficuations where they are wanted.

Mr. Speechly and others practife a method of propagating: the Vine from one eye and a few inches of the preceding. year's wood, which he prefers to thofe raifed by cuttings in the common way, for the following reafons: "They have 
more abundant roots, grow thorter jointed, are more prolific, and will, if permitted, come into bearing the fecond year."

You hould make choice of the cuttings after a warm dry feafon, fuch as laft year (1800); but not after fuch as the year before, when the wood did not ripen properly, owing to the wet and cold feafon. Each cutting thould have two inches of the old wood, with one eye of the new. When you prune your Vines you will have great choice; you thould then felect your cuttings of a middling fize, the wood round and perfectly ripened. Pots are to be filled with rich light mould that has been well meliorated and prepared fome time before. The cuttings are then to be prepared for planting, as follows. The bottom part thould be cut perfectly fmooth: and if any of the old dead fnags remain, they fhould be cut off clofe to the quick wood, and the top cut floping towards the back of the hot-houfe or frame when placed in them. I would recommend planting only one cutting in each pot, which as to fize Thould be a deep forty-eight; by that means the plants will grow much ftronger and quicker than when many are crowded together, and the fun and air will have a freer admiffion to ripen the wood; for, when many are planted in one pot, they thade one another, and in a confiderable degree prevent the fun and air from paffing freely among them. When the plants begin to get ftrong, and the pots full of roots, it will be neceffary to thift them from the forty-eights. to thirty-two's.

The above mode is beft adapted for private gardens; but for nurferymen, \&c. who raife plants for fale, and cannot conveniently fpare fo much room, it may be neceffary to plant three or more cuttings in each pot.

The 
The fame rules for watering, tranfplanting, fhifting, \&c. are to be obferved here as for Seedlings.

A method very frequently practifed by nurferymen and gardeners, when they wilh to have their plants fit for fale the fame year, is to plant them in pots, and place them in the hot-houfe, among the tan, on the flues, or round the curbs of the pit. I faw this method practifed laft year, with great fuccefs, by Meffrs. Lee and Kennedy, in their hot-houle at the Vineyard, Hammerfmith.

They may be raifed in this manner, either planting them fingly in fmall pots, or feveral in a pot, according to its frze, tranfplanting them feparately when they have taken root. In proceeding thus, it will be neceffary to have a hot-bed ready, to plunge the pots in as foon as they are tranfplanted. By this means you will forward their growth very much, and before Autumn have them fit for fale.

Vines are alfo propagated by layers in the following manner.

They may be propagated by ftools in the open quarters, in the fame manner as nurferymen propagate foreft-trees and Mrubs; but the beft way is to take layers from walls or palings, obferving to train the fhoots at full length during the Summer. Then, about the month of February, take fome of the finent and ftrongeft fhoots, and lay them acrofs the foot-path into pots (twenty-fours or fixteens) filled with frem mould, and plunged in the ground about two inches below the furface; at the fame time making an incifion or two in the old wood, or giving it a twift juft below a joint: they will generally take without notching or twifting; yet, as it is the furer way, I would advife it to be done. (Introducing the fhoots through the bottom of the pots is now laid afide, 
afide, as the layers generally have, when this method is followed, larger roots below than in the pots.) The layers thould then be cut, leaving two or three ftrong eyes upon each.

When the hoots begin to run, they thould be tied to long ftakes, to prevent their being broken by the wind. All the runners and fide-fhoots are to be picked off, leaving only-two or three fine ftrong thoots on each plant, which fhould be trained at full length during the Summer.

After the lhoots are laid, it will be neceffary to mulch them with good rotten dung, or rotten leaves, which will keep the mould moift; and in very dry Summers, fuch as the laft (1800), it will be neceffary to give them a good watering once or twice a week : this will wafh in the dung or leaves about the roots, and caule the layers to thoot more vigorounly.

By this method of laying, you may have two or three rows of layers from one wall ; taking care to lay the branches alternately, and to keep the pots plunged about two inches be. low the level of the ground.

In choofing Vines from the nurfery, I would recommend: thofe which have the ftrongeft and longeft thoots.

If the foregoing directions are properly attended to, the plants will be well rooted in the pots before Autumn, and, fit for planting in vineries, hot-houfes, \&c.

When any are to be planted out, they thould be carefully: cut off from the mother Vine and carried in the pots to where they are intended to be planted; taking care to preferve the ball as much as poffible when they are turned out of the pots.

If the feafon be warm and fine, the Grapes of early kinds ripen very well on thefe layers before they are taken up; and, 
if properly managed, they will bear fome fruit the firft year after planting. One of the ftrongeft thoots muft be left nearly at full length, cutting it as high as the uppermoit full bud, leaving nothing but round well-ripened wood. If there are three thoots, the remaining two thould be cut fo as to leave only two full eyes upon each, which hould be trained at full length, as before directed. to produce fine wood for next year. The fhoot which was trained the preceding year thould then be cut down, leaving only two frong eyes to produce wood for the following year; and fo on every year, cutting the branches alternately; by fo doing, you will be able to keep your walls always covered with fine healthy bearing wood. Thus a great deal of time is faved in furnifhing hothoufes, vineries, \&c.

This method of laying is practifed with great fuccefs by many nurferymen in the neighbourhood of London; in particular by Meffrs. Gray and Wear at Brompton-park nurfery, and by Meffrs. Kirke at Brompton; each of whom raifes annually feveral hundred plants, for which they find a great demand.

If any Vines that have been raifed from feed hould not prove to be of a good flavour, they will be very fit to graft or inarch the finer forts of Vines on: as the coarfer forts grow more vigorous than the finer, they are, for that reafon, fitter for grafting or inarching.

The beft manure for Vines is a mixture of vegetable mould *, rotten fpit dung, and frefh loam (turf and all); this fhould be thrown in a heap, and frequently turned, for a year or two before it is ufed.

* For producing vegetable mould fee p. $7 \%$.

Ob- 


\section{Obervations and Experiments on the Training and Pruning of Vines.}

The following is the method that I purfued with fome Vines which were planted againt the piers of a South wall, and among old Peaches, Nectarines, Plums, \&c.

When I took them in hand, the fruit was fo fmall and hard as to render it unfit to be fent to the table. The Vines were trained upright, which caufed them to grow fo luxuriantly that the fap flowed into the branches inftead of the fruit.

In the year 1789 I let two ftrong branches grow to their full length without topping them in the Summer. In 1790 I trained them in a ferpentine form (See Plate X.), leaving about thirty eyes on each thoot, which produced one hundred and twenty fine bunches of Grapes, weighing from one pound to a pound and a quarter each. Every one that faw them faid, that the large ones were as fine as forced Grapes; while the fmall ones produced from branches of the fame Vine, trained and pruned in the old way, were bad natural Grapes, and not above twice the fize of large Currants.

More fully to prove the fuccefs attending this experiment, I next year trained five plants in the fame way, allowing the thoots intended for bearing wood to run to their full length in Summer, training them wherever there was a vacancy between the old trees; where there was none, I ran them along the top of the wall, without topping them. In Winter I trained them in a ferpentine manner fo as to fill the wall as regularly as poffible: they were as productive as thofe in the former year. 
After a three years' trial, I thought I was warranted to follow the fame practice with the whole; and in the year 1793 I fent, for the ufe of his Majenty and the Royal family, three hundred and feventy-eight bafkets of Grapes, each weighing about three pounds, without planting a fingle Vine more than there were the preceding year, in which I was able to fend only fifty-fix balkets of the fame weight; and thofe fo bad and ill-ripened that I was afhamed of them, as they were not fit to be fent to the table.

In this year there was more than a quarter of the crop. deftroyed by birds and infeets, and rotted by the wet.

Although the above ftatement is within the bounds of truth, it may, appear to the reader like an exaggeration; but it is in the power of every one who will follow the directions here given to prove the advantage that will accrue from this. method of training:

The above experiments were all made on the natural walls, and I hope will be fufficient to convince every unprejudiced. perfon of the great advantage that the ferpentine method of training Vines poffeffes above the common way.

It may be proper to obferve, that the fhoots fhould be: brought as near as poffible from the bottom of the $V$ ine, that: the wall may be well covered. When the walls are high, and the fhoots from the ferpentine branches ftrong, we fometimes. let them remain; but if the walls are low, and the ferpentine: branches produce weak thoots, we cut them out in the Au-. tumnal pruning, and train up the frrongeft of the younger wood in their room; as directed in the explanation of: PLATE.X. 
On the Pruning and Training of Vines.

It is to be obferved, that the wood muft be ftrong, or the Vines will produce fmall bunches. If that be the cafe, cut them down to two or three eyes, in order to have ftrong wood for next year. Vines bear their fruit on the wood that was produced the preceding year. If there be a great deal of old naked wood on them, as generally is the cafe, with fome fmall weak thoots at the extremities, always cut them down as near to the ground as poffible; you will then have no fruit for that year. Or you may cut every other fhoot, leaving the old ones to produce fome fmall Grapes. The next year you will have plenty of fine wood, provided you take care to nail in the ftrongeft fhoots, and pick off all the fide-fhoots that are produced from the eyes, pinching them off with the finger and thumb, or cutting them out with a harp penknife clofe to the bud or eye; but never twift them; for by twifting them you will hurt the bud that produces the Grapes next year; always obferving to cut as near to a bud as poffible, and taking care to lay in the wood very thin in Summer, that the fun and air may be freely admitted to ripen it: by thefe means it will grow very frong. Take care alfo to keep the Ihoot's nailed to the wall, which will prevent their being broken by the high winds; obferving to pick off all the fidethoots every time you nail them, which ought to be done feveral times during the Summer months, according to the quicknefs of their growth. In fine weather they will grow fo very quick, that you will have occafion to look over them once every fortnight or three weeks, if you win to have them 
in good order. Never fuffer the Vines to run together in a clufter, and to mat, which will infallibly ruin them for bearing the fucceeding year. Top the fhoots that have been trained in a ferpentine manner, as foon as the Grapes come to the fize of very fmall Green Peas, a joint or two above the fruit; but never top the leading fhoot, nor that which you intend thould bear fruit next year.

I thall now give fome directions for the fecond year's pruning.

I would never recommend the pruning of Vines till the beginning of February, except in fuch a feafon as the prefent; for they are more forward now (in the middle of January) than they were laft year in the latter end of March: this is owing to the fine Autumn and mild Winter, and the wood being fo well-ripened in the preceding Summer. It is, however, very common with fome to begin pruning foon after the fall of the leaf, before the wood becomes hard; but if a froft fets in before the wood is hard, in particular after wet Summers and Autumns, it will be very much injured; $I$ have frequently feen it almoft killed after Autumnal pruning. We often have fine weather in the months of October, November, and December, with fun and drying winds, which helps to ripen the wood after wet Autumns.

When the Vine leaves begin to fall, remember always to take a foft broom and fweep them off upwards in a gentle manner, which will be of great fervice in affifting to harden the wood.

When you begin to prune in February, always make choice of the ftrongeft and longeft fhoots, leaving them as long as you find the eyes good and plump, and the wood round; but by no means leave them when they become flat; as in that 
cafe they feldom bear fruit; and if they do, it will be very fmall. I never lay in any that has lefs than fifteen, and from that to thirty good eyes, according to the frength of the Ihoot, which will produce two bunches from every good eye. I have had feventy bunches of grapes from one fhoot. The fhoots that have borne fruit in the preceding year fhould be cut out next year, except when you want to fill the wall, and the thoots are very ftrong. You will always get plenty of fine healthy young wood if you are careful when you prune in the Winter; therefore never leave any but fine ftrong wood, always cutting at the fecond, third, or fourth eye; remembering to rub the loweft bud off, and that which comes out at the joint between the new and laft year's wood. By thefe means you will get as much fruit from thefe thort thoots as you would have by the common way of pruning. You muft always obferve to leave two or three of the ftrongeft Thoots for next year's bearing wood, and never top them. If you have not room to train them, you may lead them over the tops of the other trees, if the Vines are planted againft Piers; or you may run them behind the ftandards, if there be any, which is generally the cafe when the walls are high; thus you will cover all the wall, which will have a very beautiful appearance when the fruit is ripe, befides furnithing a plentiful fupply of fine Grapes for the table. You may run the fhoots at the bottom of the wall behind the dwarf trees, or you may tack them down over the top of the wall on the other fide, provided the walls are low. I have had very fine Grapes on Eaft and Weft walls, in good feafons, between Peaches, Plums, \&c. particularly when the trees are young. You mult keep cutting in the Vines as the other trees grow and fill up the walls. I alfo train them over the tops of trees. 
on each fide; which never does any harm to the trees below, provided you keep them nailed to the wall. I have alfo planted Vines between trees on North and Eaft afpeets, and trained them over the tops of the South and Wert walls to fill the upper parts, till the Peaches and Nectarines cover them. I then cut away part of the Vines, leaving only as many thoots as I may think neceffary.

Two years ago I removed fome old Apricots that covered a wall about one hundred and fixty-five feet long, and planted them againft a new wall, leaving five Vines that were planted againft the Piers. Thefe five plants have, in the courfe of two years, covered the above wall from top to bottom, and bear plenty of fine Grapes every year. 1 alfo moved an old Vine on a wall near to the above, and cut it in pretty clofe ; it has in three years fpread twenty-fix yards, and bears very fine fruit.

Againft one of the Piers had been planted a black Hamburgh Grape; and at the other fide of the fame Pier was planted a Mufcadine, at the diftance of about two feet from each other; I pruned them both according to my method, and, the fecond year after, they produced one thoufand one hundred bunches of fine Grapes.

I alfo tried an experiment by taking fome fhoots from a South wall, opening the ground deep enough to lay them in acrofs the footpath at the diftance of about four feet from the wall, and tied them to fakes, training them as Efpaliers, laying in the wood as directed for walls, and keeping them as low as poffible, that they might not thade the bottom of the wall: I alfo pruned them as I do thofe againft walls, laying the thoots in very long, except thofe that were intended to bear fruit next year, from which I took off all the 
fide-thoots and runners againft the wall and Efpaliers. In a favourable feafon thefe bear very fine fruit, better than what is got from the walls by the old method of pruning.

Always obferve to ufe the Compofition as foon after pruning as poffible. As the Vine is very porous, it foon imbibes the wet and moifture, which brings it quickly to decay.

If at any time a Vine fhould be cut late in the feafon, it will be apt to bleed much; in that cafe, the powder muft be applied, repeating the application till the bleeding ftops.

I cut two ftrong Vine-branches in the month of June and three more in July, in very hot weather, on purpofe to try the effect of the powder in ftopping the bleeding. The fap rofe fo ftrong that it worked out at the top in a froth; I applied the powder, which in a fhort time entirely ftopped it.

Although the foregoing directions and obfervations are: chiefly for Vines on the natural wall, I have recommended the fame method to be practied for forced Grapes.

\section{Rall now give Jome Directions for the Watering of Vines:}

After the Grapes are fet and begin to fwell, you may water them with the Barrow Engine, fprinkling them all over the leaves and fruit, prefing your forefinger over the top of the pipe; by doing this you can throw the water as fine as fmall. rain, which will walh all the duft off the Vines and leaves, that are frequently covered with it, efpecially if the garden be near a public road, as is the cafe at Kenfington. You hould alfo wah the infects off the trees. In fine weather I prinkle all the wall-trees three times a week, which keeps them clear from infects, and promotes the fwelling of the fruit; but this 
operation muft never be performed when the nights are cold and frofty. You thould begin to fprinkle the trees when the fun is in an oblique direction, or gone off the wall, which may be about four o'clock on a South afpect; by doing it at this time, the leaves will have time to dry before night, and fo prevent the froft, if there thould be any in the night, from injuring them. In very hot and dry weather, give the trees a good bottom watering once a week, which will forward the fwelling of the fruit. Vines require a great deal of watering; but when the fruit is fully fwelled, you thould leave it off; particularly when the nights begin to get cold, as it would hurt the flavour of the fruit.

We fhall fay fomething in this place refpecting the prefervation of Grapes from flies, wafps, and birds; but for full directions on that head, fee the Chapter ON INSECTs, Src.

As foon as the large fly makes its appearance, you muft provide plenty of bottles a little more than half filled with fome fweet liquor to entice the flies to enter them, where they will be drowned. You muft hang the bottles on the nails at proper diftances all over the Vines, and alfo place fome of them at the bottom of the walls. The blue fly comes much earlier than the wafp, and you will find it no lefs deftructive to the fruit. It will therefore be neceffary to hang up the bottles betimes, in order to deftroy as many of them as poffible before the wafp makes its appearance, and have the bottles ready for this fecond enemy.

When the Grapes begin to ripen, you will be troubled with other enemies; the birds will now begin to attack the fruit; it will then be neceffary to bag fome of your fine handfome bunches, but to bag them all would be an endlefs job, if you have a full crop and a large garden. I have had five men bagging 
bagging for three weeks, and yet could not bag the half of what were on one wall.

Where the bunches are very thick, the quicken way is to cover the trees with nets, or buntine (a kind of fuff of which thips colours are made), which will admit a free air to the Grapes, and will dry foon after rain. They will alfo be a good covering for the trees in the Spring, in cold, wet, or fnowy weather. Always obferve, that the bunches of Grapes fhould be kept under the thade of the leaves till they begin to ripen; then you may begin to pick off the leaves which cover the fruit, (leaving thofe a little above it to be a fhelter from the wet and froft in the nights); this will afff the ripening of the fruit; and take off only a few leaves at a time, according to the quantity of Grapes to be gathered at once: by thefe means your fruit will continue three times as long in fucceflion as it would if the leaves were picked off all at one time.

I have often feen all the leaves taken off from the fruit foon after it was fet, which prevents it from fwelling, and the fruit will become hard and fmall, and will generally crack.

When the leaves are not too thick, they admit the rays of the fun to pafs through, and a warm glow of heat will be reflected from the wall.

You may find it convenient to let the Grapes hang as long on the walls as you can: I have often let them hang till the middle of November, only covering them with nets, or buntine.

When the froft begins to fet in harp, you fhould then gather the Grapes. Where there are feveral bunches on one branch you may cut it off, leaving about fix inches in length, or more, of the wood, according to the diftance between the 
bunches, and a little on the outfide of the fruit at each end: feal both ends with fome common fealing-wax, fuch as Wine Merchants ufe for fealing their bottles with, which you may buy at the Wax Chandler's; then hang them acrofs a line in a dry room, taking care to clip out, with a pair of fciffars, any of the berries that begin to decay or become mouldy, which if left would taint the others: In this way I have kept Grapes till the fixth of February; but, if they are cut before the bunches are too ripe, they may be kept much longer.

Having plenty of Grapes in the Winter makes a great addition for the table; and, if properly kept, they will be of a much finer flavour than the Portugal Grapes, which are generally at a very high price during the Winter and Spring. Grapes may alfo be kept by packing them in jars (every bunch being firft wrapped up in foft paper), and covering every layer with bran, which thould be well dried before it is ufed, laying a little of it in the bottom of the jar; then a layer of Grapes, and fo on, a layer of bran and of Grapes alternately, till you have filled the jar; then thake it gently, and fill it to the top with bran, laying fome paper over it, and covering the top with a bladder tied firmly on to exclude the air : then put on the top or cover of the jar, obferving that it fits as clofe as poffible. Thefe jars thould be kept in a room where you can have a fire in wet or damp weather. 
$(\$ 31)$

\section{CHAPTER IX.}

OF FIGS.

Different Sorts defcribed-Of Raifing, Pruning, Training, and Sheltering Fig-Trees.

THE Fig has been cultivated in England ever fince the year 1562. Some of the oldert that we know of in this kingdom are in the Archbifhop of Canterbury's gardens at Lambeth.

This genus of plants is arranged in the third order of Lin. næus's twenty-third clafs, entitled Polygamia Triœcia.

The following are the Sorts beft roorth cultivating in this Country.

1. The Brown, or Chefnut-coloured Ifchia Fig. This is one of the largeft that we have : it is of a brown or chefnut colour on the outfide, and purple within; the grains are large, and the pulp fweet and high-flavoured. It ripens in

$\mathrm{S} 2$

Augurt; 
Auguft; and, if planted againft a hot-wall, two crops may be obtained annually.

2. The Black Genoa Fig is a long fruit of a dark purple colour, the infide being of a bright red, and the fiefh very high-flavoured. It ripens in the latter end of Augurt.

3. The Small White Early Fig. The fkin of this fruit is of a pale yellow when ripe: the fleth is white and fweet. It is ripe about the latter end of Augunt, or beginning of September.

4. The Large White Genoa Fig. This is a large fruit, the $\mathrm{kin}$ is thin and yellow when ripe, and red within. It is a good fruit, and is ripe about the latter end of Auguft. This and the preceding bear two crops annually.

5. The Black Ifchia Fig is a middle-fized fruit ; the $\mathrm{kin}$ is almoft black when ripe, and the infide of a deep red. The fleth is high-flavoured, and the trees good bearers.

6. The Brown and Black fmall Italian Figs are cultivated. in pots; the fruit is fmall, round, and very delicious. I have gathered from one plant in a twenty-four pot two dozen of Figs at one gathering.

7. The Malta Fig. This is a fmall brown Fig; the $1 \mathrm{kin}$ of a pale brown, the infide of the fame colour; the fleth is fweet and high-flavoured. It is ripe in Auguft and September.

8. The Murrey, or Brown Naples Fig, is a pretty large fruit of a light brown colour, and the infide nearly of the fame colour; the flefh is well-flavoured; and it ripens about the middle of September.

9. The Green Ifchia Fig is an oblong fruit with a green fkin; but, being thin, is ftained through of a brownith caft by the pulp when full ripe. The infide is purple, and the 
flefh high-flavoured; it is ripe about the middle of September.

Iо. The Madonna Fig, commonly called the Brunfwick, or Hanover Fig, is a large pyramidal fruit; the fkin brown, the flefh a lighter brown, coarfe, and has but little flavour. It ripens about the middle of September.

I1. The Common Blue or Purple Fig is a large oblong fruit, ripens in Auguft, and is a good bearer.

12. The Long Brown Naples Fig. The $\mathrm{kkin}$ of this fruit is of a dark brown when ripe, the fleth inclining to red; it has large grains and a good flavour, and ripens about the beginning of Oetober.

13. The Small Brown Ifchia Fig is a fmall pyramidal fruit; the fkin of a light brown; the flefh of a purple calt, and of high flavour. It ripens in October.

I4. The Yellow Ifchia Fig is a large fruit, the fkin yellow, and the flerh purple and well-flavoured. It ripens in October.

15. The Gentile Fig is of a middle fize, roundin fruit, the fkin yellow, and the flem inclining to the fame colour. It has large grains, and a good flavour; ripens very late, and the trees are but indifferent bearers.

There are alfo the following, viz.

Beft Early White.

Black Provence.

Cyprian.

Ford's Seedling.

Green Naples.

Large Black.
Large Blue.

Marfeilles.

Milward.

Small Black Ifchia.

White Ifchia.

Yellow Cæfar. 


\section{Figs proper for a fmall Garden.}

The Large White Genoa; Early White; Murrey Fig; Small Brown Ifchia, and the Black Ifchia.

In a good feafon, the Brown or Chefnut-coloured Ifchia, the Black Genoa, the Small White Early, the Murrey or Brown Naples, and the Common Blue, or Purple Fig, will ripen on ftandards.

Figs are raifed from fuckers, layers, or cuttings, and will thrive in almort any foil, but do not like a wet bottom; they generally produce more fruit on a ftrong loamy foil than on a dry one. Layers, or cuttings, are preferable to fuckers.

\section{Obfervations, \&c. on Pruning Figs.}

They fhould never be pruned in Autumn or during the Winter: the beft time is at the latter end of April or beginning of May; by that time you will fee what Thoots have been killed by the froft in Winter. The end of thofe branches more particularly will be hurt where the wood has not ripened well in Autumn: they Thould be cut into the found wood, and as near to an eye as poffible. When the branches have been fuffered to run up leaving the bottom quite naked, you fhould cut out every other branch as near to the ground as you can, which will furnith the wall with fine young wood; obferving to ftop the ends of the thoots in the beginning of June; this will caufe them to throw out 
fide-thoots which will bear fruit the next Summer. By that time you will have plenty of fine wood; you may then cut down the reft of the old branches that were left the preceding year, obferving to prune them about the fame time as you pruned laft year: always remember to pinch off the ends of the ftrongeft thoots, except the leading ones, at the top bud.

When you prune in the Spring, never fhorten the fhoots, as the fruit is produced near the tops. There will be a great many fine thort fide and foreright thoots which thould never be cut off but when they are decayed. Thefe thoots will ripen much better than the long ftrong ones, and will not be fo liable to be killed by the froft in Winter. By following this method, you will have the trees covered with fruit from the top to the bottom of the walls, inftead of having a few fruit only at the top, which is the cafe when the common. method of pruning is practifed.

When the Figs are about the fize of fmall Nutmegs, you fhould pinch off the point of the top bud with your finger and thumb, or cut it with a tharp pen-knife; and always remember to ufe the powder, wherever you cut or pinch, to ftop the oozing of the milk, which, if fuffered, would greatly. exhauft and injure the trees.

Take care not to lay in the branches too thick; they. thould be from a foot to eighteen inches diftant.

The trees muft be covered in the beginning of Winter before the froft fets in, otherwife the ends of the fhoots will be hurt by the firft tharp froft, before the wood is ripened and hardened, which will oblige you to cut them as before. When Fig-trees are very much injured in hard Winters, the beft way will be to cut as near the ground as poffible; and 
the fecond year you may get them into a fine bearing ftate, if you manage them as above directed.

I thall now give fome directions as to the beft method of covering them.

I generally cover them with bentings, or thort grafs, from the pleafure ground; which I find anfwers the purpofe very well: after it is thoroughly dry, it may be put in a cock, covering it with ftraw to prevent the rain from penetrating into it, which will caufe it to heat and rot; or it may be put into one of the theds. If you cannot procure grafs, get lome dry mols. Firft cover the trees with laurel, yew, fir, or fpruce boughs, and then tuck in the hort grafs or mofs among the branches, beginning at the top of the tree, tucking in the grafs, \&c. as you defcend, till you come to the bottom. Fern, when well dried, makes an excellent covering. You may thatch the tree on the outfide with the long leaves of the common fern; when you can get thefe, there will be no occafion for thort grafs. Fern, when it can be procured, which it may in moft country places, will be found preferable to laurel.

Figs may alfo be theltered in Winter by wrapping hay or ftraw-bands round the branches of the trees; then open the ground, lay in the branches, and cover them over with mould about nine inches deep, leaving the ends of the thoots about three inches out of the ground, and covering the ground over with fome rotten leaves, or old tan, \&c. to keep out the froft: you may alfo cover the roots of the trees in the fame manner.

If the walls are low, and the borders broad, you may bring all the branches front ways; but when the walls are high 
you can only bring the fide branches forward in the above manner.

Some cover with reeds and ftraw; the latter I by no means approve of, as it is very apt to harbour rats and mice on account of fome of the grain being left in it.

Be careful to obferve, when you put on the grafs, that no mice, \&c. have got amongft it; and examine during the Winter that no rats or mice get among the branches of the trees that are covered againft the walls; if they do, they will infallibly bark the branches, and in that cafe you will be under the neceffity of heading the trees down.

I would recommend fetting traps, fuch as thall be defcribed hereafter, near the roots of the trees, as foon as they are covered.

Take care not to uncover the Figs too foon in the Spring; and it hould be done partially, as frequently there are frofts and cutting winds in the months of April and May, which will infallibly kill the young fruit as they make their appearance in the Spring.

Thofe branches which have been laid into the ground fhould be taken up in the month of April, taking off the hay and ftraw bands, and then nailed to the wall. Stick in among the branches fome fern-leaves, or any other light covering, to protect them from the drying winds and frofts, till the fruit comes to the fize of a large walnut, or rather till the leaves are fufficiently large to proteet the fruit.

The Italians, when they with to forward the ripening of Figs, drop in a little fweet oil, from a quill, into the eye of the fruit; but care muft be taken not to hurt the fkin, which would make the Fig burnt. This will make a difference at leaft of a fortnight in the ripening. 
As foon as the leaves begin to fall, bruth them off with a broom, but by no means till they will come off eafily. If they are forced off before they begin to wither and decay, the trees will bleed at the footfallss. At the fame time you fhould clear the ftalks of all the fmall late fruit, which, if fuffered to remain during the Winter, will rot, and injure the tree fo as to prevent it from bearing the enfuing Summer. If you obferve any milk oozing from the footfalks, ufe a little of the Compofition, which will ftop it and heal the injured part. By doing this, you will aflit the ripening and hardening of the wood before the Winter frofts fet in.

When you plant Fig-trees, let them be from twenty to twenty-four feet apart, and train them horizontally, which will render them much more fruitful than when they are trained upright, which caufes them to run up in long naked wood.

Obferve alfo to leave fpurs, or thort thoots, all over the branches; and when the buds begin to fwell, all the thort thoots fhould be pinched, as before directed.

As the branches of ftandard. Fig-trees are very liable to be killed in fevere Winters, it will be neceffary to lay them alfo in the ground, wrapping them up in hay or ftraw bands, as before directed for wall-trees. It will be fometimes impracticable to lay down the middle branches; they muft; therefore, be well covered with hay or ftraw-bands, and the outfide ones laid down, going regularly round the tree, and taking particular care not to hurt them with the fpade; then mulch them with rotten leaves, \&c.

After hard Winters, I have frequently been obliged to cut Fig-trees down very near to the ground, and apply the Compofition: 
pofition: in the courfe of two years the new wood has covered over the old fump, and the branches filled up the former fpace, bearing alfo plenty of fine fruit.

In a plentiful year, when there are more than you want for the fupply of the table, the remainder may be dried for Winter ufe. 


\section{CHAPTER X.}

OF QUINCES.

The beft Sort for the Kitchen Garden-Of their Propagation, Planting, and Pruning-Of Bark-bound Trees, and of theje which have rough Bark.

THE Quince is called Cydonia, from Cydon, a town of Crete famous for this fruit.

It belongs to the fourth order of the twelfth Clafs of the Sexual Syftem, Icofandria Pentagynia. Linnæus has joined it to the Apple and Pear.

This is a very beautiful tree when in flower, and when the fruit is ripe in Autumn. It was cultivated in this country in Gerard's time.

The beft fort for planting in the Kitchen Garden is the Portugal, being the fittent for baking or ftewing. It is of a fine 
fine purple colour when dreffed, and is much better for Marmalade than any of the other forts. The oblong kind, and the Apple Quince, are alfo planted in fruit-gardens; and there are feveral other forts cultivated in the nurferies about town, and planted in Thrubberies for variety and ornament. The Portugal fort is very ufeful to mix with Apples for making pies and puddings; for when the Apples are flat, and have lon their flavour, they add a quicknefs to them.

\section{Of the Propagation and Pruning of 2uince Trees:}

They are eafily raifed by layers, or by cuttings taken from the tree in March. They thould be planted in a mady place, in rows at about a foot diftant from each other, and about three inches from plant to plant in the rows. Mulch them with rotten leaves, or rotten dung, which will keep the ground about them moift; and water them frequently in hot weather. About Michaelmas thofe that are well rooted may be planted out, and thofe that are not thould remain another year. They may alfo be propagated by budding or grafting; and thefe trees will bear fooner, and be more fruitful, than thofe raifed by any other method.

The Quince-tree may be pruned much in the fame way as you would prune an Apple-tree, taking care to cut out all the old difeafed and dead wood, and the crofs branches in the middle of the tree, which are apt to injure each other by friction. In general you will find old trees much hurt by injudicious pruning: in that cafe, you mut head them down, cut out all the cankery parts, and alfo all the difeafed and dead wood where the tree is hollow, or where large 
branches have been cut or broken off; applying the Compofition as for Apple-trees.

Quince-trees are very apt to have rough bark, and to be bark-bound: in that cafe, it will be neceffary to mave off the rongh bark with a draw-knife, and to fcarify them when bark-bound; then brufh them over with the Compofition, as hereafter directed.

I would, however, advife to plant Quince-trees at a proper diftance from Apples and Pears, as bees and the wind might mix the Farina, and occafion the Apples or Pears to degenerate. 


\section{CHAPTER XI.}

\section{OF MEDLARS.}

Different Sorts-Their Propagation and Manner of Treatment.

THE Medlar is ranged in the fourth order of Linnæus's twelfth Clafs. Icofandria Pentagynia.

\section{The Different Sorts cultivated in this Country are,}

The Great Medlár with bay leaves, and the Dutch Medlar. Thefe, being the largeft fruit, are generally cultivated in England. There is a fmaller fort, which is a variety of that called the German or Dutch Medlar; the fruit is fmall; and the tree is more frequently planted in pleafure-grounds than gardens.

The oriental fort, according to Mr. Philip Miller, is called the Dwarf Cherry of Mount Ida, in Crete, where the thepherds feed upon the fruit. It is large, roundifh, and of a fine red colour when ripe.

There 
There are feveral fpecies now growing in the gardens of this country, that have been introduced from North America, which are very ornamental in pleafure-grounds and parks, and to whofe fruit the decr and birds are very partial.

They are raifed from feed, or by grafting; thofe who wifh to keep the forts true thould, propagate them by grafting on their own ftocks.

The Medlar requires much the fame fort of treatment as the Qinince-tree. Cut out all the dead and cankery wood; and, when they begin to get ftunted, head them down, and apply the Compofition, as directed for Apple-trees.

Medlars fhould hang upon the tree till they begin to rot, as thofe who are fond of this fruit never eat it till the pulp is quite foft. It may be proper to obferve here, that thofe who wifh to have their Medlars large and fine, muft keep the tree thin of wood.

As many people are fond of the fruit of the Medlar, I would recommend planting fome trees of the large Dutch fort in the kitchen garden; the other forts may be planted in pleafure grounds and parks.

There is a fort called the Nottingham Medlar, which is very much efteemed by fome for its tharp and poignant tafte.

Medlars, as well as Quinces, thould be planted at a proper. diftance from Apple and Pear-trees. 


\section{CHAPTER XII.}

\section{OF GOOSEBERRIES.}

Different Sorts of Goofeberries; and the Weight of many large nero ones from Manchefter-The Propagation, Planting, and Pruning of Goofeberries - A Method of deftroying Caterpillars.

THE Goofeberry and Currant are ranged by Linnæus in the firft order of his fifth Clafs, Pentandria Monogynia.

The Goofeberries common in this Country are,

Green Gafcoin.

Smooth Green.

Early Black.

Small Early Red.
Hairy and Smooth Red. Large Smooth Yellow. Large Rough Yellow. Common, and Large White. Large Smooth Dutch Yellow. Champaigne. 
1 Lift of the largeft nero Sorts fhown in Lancafirie laft Summer (1800), with their Colour and Weight, communicated by: Meffis. M'Niven, Nurferymen, Manchefer.

Red Gooseberries. dw. gr. dw. gr.

\begin{tabular}{|c|c|c|c|c|c|c|c|c|c|}
\hline $\begin{array}{l}\text { Alcock's King }- \\
\text { Duke of York }\end{array}$ & - & - & 16 & 15 & $\begin{array}{l}\text { Robinlon's Crudus } \\
\text { Withington's Scepter }\end{array}$ & & - & & \\
\hline an's Royal Oak & - & - & 15 & 4 & Green Gooseb & $e b$ & & & \\
\hline rit's Atlas - - & - & - & 17 & 1 & & - & - & - & 17 \\
\hline n's Peerlefs - & - & - & 15 & 21 & $\mathrm{Oa}$ & & - & - & 14 \\
\hline Slory of England & & - & 16 & 2 & kle Tob & by & - & - & 14 \\
\hline ord Hood & - & - & 84 & 5 & Hero & - & - & - & 13 \\
\hline onqueror & - & $\overrightarrow{.}$ & 17 & 19 & & - & - & - & 15 \\
\hline ker & - & - & 15 & 8 & een & - & - & - & 16 \\
\hline upine - & - & - & 13 & 20 & & - & - & - & 15 \\
\hline Etory & - & - & 16 & 11 & & - & & - & 13 \\
\hline & - & - & 3 & & & - & 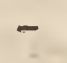 & - & 13 \\
\hline eer - & - & - & 16 & & & & & - & 14 \\
\hline $\begin{array}{l}\text { Worthington's Glory of } \\
\text { Yellow Gooseber }\end{array}$ & & & 14 & 10 & & & & - & 12 \\
\hline dney & - & - & 15 & 22 & Hal & & - & - & 14 \\
\hline port's D & - & - & 15 & 12 & aland & & hite & - & 12 \\
\hline - Creeping & & - & I 6 & 0 & ıdy & - & - & - & 15 \\
\hline$n--$ & - & - & 15 & 9 & - & - & - & - & 14. \\
\hline Gourd - & - & - & 13 & 17 & Mun & & & - & 13 \\
\hline gn & - & - & 17 & 10 & & & - & & 13 \\
\hline f Orange & & - & 15 & 0 & & - & - & & 14 \\
\hline finder & & & & & a & & & & 17 \\
\hline
\end{tabular}

In favourable Seafons, many of the above forts have been known to weigh more by feveral pennyweights. 
The following Lift is taken from the Catalogue of Mefrs. Kirk, Nurferymen, at Brompton, near London.

Supreme Red.

Perfection Red.

High Sheriff of Lancalhire.

Royal George.

Unicorn.

Rough Amber.

White Walnut.

Ackerley's Double Bearer.

Royal Oak.

Mifs Bold's.

Sparkler.

Akerley's Rodney.

Hampfon's Cæfar.

Monk's Charles Fox.

St. John.

Pigeon Egg.
Golden Eagle.

Royder's Triumph.

Williamfon's Yellow Hornet.

Swingham.

Jackfon's Golden Orange.

Goliah Champion.

Warrington Red.

Golden Drop.

Cofterdiner Goliah Champion.

Hairy Amber.

Nixon's Golden Eagle.

Worthington's White Lily.

Laylord's Seedling.

Nixon's White Heart.

Riding's Old England.

Bakeley's Swingham.

Tillotfon's St. John.

\section{On the Cultivation, \& c. of Goofeberries.}

Goofeberries are raifed from cuttings, or from feed, and fome raife them from fuckers; but this laft is not a good way, as buthes raifed in this manner are more liable to throw out fuckers than thofe which are raifed from cuttings or feed.

The beft time for planting cuttings is about Michaelmas, $\mathrm{U} 2$ always 
always cutting them from the frongeft and cleaneft fhoots. The length of the cuttings thould be from fix to eight inches, planting them on an Eaft or North border, at the diftance of one foot from row to row, leaving them about three inches above ground. By planting at this diftance, you will be able to hoe and keep them clear of weeds. Water them frequently in dry weather during the Spring.

\section{The Methods of Planting Goofeberries are various.}

The Market-Gardeners about London plant them in rows from eight to ten feet apart from row to row, and fix feet from plant to plant in the rows. In that cafe, I advife pruning them in the beginning of October, and the ground between may be planted with Coleworts or Beans for a Spring crop; by fo doing, there will be no occafion to tread over the ground and hurt the Coleworts in pruning the burhes; for, before the Goofeberries begin to thoot, the Coleworts will be all cleared off the ground.

After this time (or before if you find it convenient) lay a good coat of rotten dung on the ground; then dig it and plant early Potatoes; but not fo near to the Goofeberries as to hurt them.

The roots of Goofeberries fhould always be kept clear to admit the fun and air. In fmall Gardens I would recommend planting them in quarter by themfelves, at the diftance of fix feet between the rows, and four feet from plant to plant; or you may plant them round the edges of the quarters, about three feet from the path; you will then have the ground 
clear for cropping, and a man, by fetting one foot on the border, can gather the Goofeberries without injuring the crop.

As Goofeberries love a rich foil, they fhould be dunged every year, or at leaft have a good coat of dung once in two years.

Never plant them under the fhade of other trees, as it will injure the flavour of the fruit.

\section{Of Pruning Goofeberry-bufhes.}

It is a practice too common in pruning Goofeberries, to let them branch out with great naked ftems, fuffering them to remain in that flate for years. When that is the cafe, they Thould be cut down near to the ground in the Winter: pruning; this will make them throw out fine ftrong healthyThoots which will bear fruit the fecond year. Goofeberrybuthes, in general, bear their fruit on the fecond year's wood. Care fhould be taken in Summer to keep the middle of the burh clear to admit a free air into them; leaving the finent and ftrongeft thoots from fix to ten inches diftant from each other. This will help to ripen and harden the wood. It is a practice with fome to thorten the fhoots in the Autumn or Winter pruning: this thould be always near to a wood-bud; which may be known by its being fingle, whereas fruit-buds are in clufters. The thoots may be mortened to eight or ten inches, according to their ftrength. Some leave them at full length for three or four years, thinning out thofe that are fuperfluous. Always leave a proper number to be trained up between the full length fhoots, to fucceed them when they. 
are tired of bearing; then cut the old ones down to the young ones that are to fucceed them. By thefe means you will always keep the bufhes in a conftant ftate of bearing.

You may obferve, that thofe branches which were cut the firft year, will in the fecond throw out hort dugs, or fpurs, which produce the fruit; and thefe thould by no means be cut off, unlefs the branches are in a fickly ftate, and require to be cut clofe down (as is the cafe this year, 1800), when the buthes are overloaded with fruit. It will then be neceffary to cut out a good deal of the old wood, to affint Nature to recover herfelf after producing fo great a quantity of fruit. This year the buthes are fo loaded that the branches are bent down to the ground.

Goofeberries are well worth paying attention to, as they fupply the table fo amply till the wall fruit comes in.

There have been confiderable additions made to them, of late years, from the great attention that has been paid, by the gardeners and others of Manchefter and its neighbourhood, to raifing Goofeberries from feed.

Their Catalogues now contain between four and five hundred forts or varieties; but fome are fo near each other as hardly to be diftinguifhed. By mixing up a rich foil to plant thofe in which have been raifed from feed, and by watering, thading, and thinning the fruit, they have grown to a fize much larger than any that had ever been feen in this country. They have made it their principal ftudy to improve this valuable fruit, and have given great encouragement, by eftabliming focieties for diftributing prizes annually to thofe who raife the largeft and fineft new forts But it muft be allowed, that fome of the largeft are much thicker in the fkin, and not fo well flavoured as fome of the old forts. 
I enquired of Meffrs. Mc Niven, Nurferymen at Manchefter, how many good and difinet forts they could fend me out of their numerous Catalogue; they told me, that they could fend about eighteen or twenty forts, which they could anfwer for being good and diftinet. I accordingly gave an order; and received all the forts that they could warrant good, which turned out to my fatisfaction.

Great attention fhould be paid to the cultivation of the early and late forts. In fome old gardens, in particular, there are very valuable forts that have been of late too much neglected: I would therefore recommend to thofe who live in the neighbourhood of fuch gardens, to obferve their time of ripening, and to cultivate thofe efpecially which are early and late.

It is a practice with fome to clip the tops of Goofeberries with a pair of garden thears, as they would clip a thorn hedge; this I by no means approve of, as the fruit will not be half the fize, nor of fo fine a flavour, as. when the bufhes are kept clear of fuperfluous wood.

Care thould be taken in Spring and Summer to ftock, or grub up, all the fuckers from the roots of the buihes, leaving their ftems clear and unencumbered.

Many of the Lancalhire forts are apt to grow horizontally, and the branches frequently trail on the ground, which renders them liable to be broken by high winds, efpecially when they are loaded with fruit. In that cale I would recommend two or three hoops to be put round them, to which the branches may be tied, to fupport them, and prevent their being broken by the wind.

Thofe who with to have their Goofeberries very late fhould plant on North walls and palings, between the other trees, 
and they may be removed when the trees begin to meet. If laid in thin, they will bear very fine and handfome fruit. I would advile to plant the fineft late forts; as by this method the table will be fupplied much longer than by the common cuftom of planting in quarters.

Immediately after pruning, I always apply the Compofition to the ends of the thonts and cuttings; and I find it of great ufe in preventing the exhalation of the fap, and preferving the cuttings till they take root.

Goofeberries are very much infefted with a fmall green caterpillar, which frequently devours both leaves and fruit.

You mun, therefore, be very attentive, and obferve their firft appearance on the buhes; for, if not deftroyed early, they will increafe fo fat, that they will foon devour all the leaves, and the fruit will then be good for nothing. They make their firft appearance generally on the edges and underfides of the leaves.

Take fome fifted quick-lime and lay it under the buthes; but do not at firft let any of it touch the branches or leaves; then thake each buh fuddenly and fmartly, and the caterpillars will fall into the lime; if the burh be not thaken fuddenly, the caterpillars, on being a little difurbed, will take fo firm a hold as not eafily to be thaken off. After this is done, fift fome of the lime over the bufhes; this will drive down thofe which may have lodged on the branches. The caterpillars ought to be fwept up next day, and the bufhes well walhed with clear lime-water mixed with urine; this will deftroy any caterpillars that may fill remain, and alfo the Aphides, if there are any on the bufhes. 
( 1.53 )

\section{CHAPTER XH.'}

OF CURRANTS.

Different Sorts of Currants-Propagation, Planting, and Pruning: of. them-How to preferve them from Infects.

CURRANTS, with Goofeberries, are arranged by Linnæus in the firtt order of his fifth Clafs, Pentandria Monogynia.

The forts moft commonly cultivated in this country are, the Red and White Dutch Currants, and the common Black, and American. Black. Currants.

The following Sorts are alfo cultivated by the Nurferymen: about:

Town, and in other parts of England, viz.

Common Red.

Champagne large Palè and Red.

Fine new White Dutch.
Long-bunched Red.

Striped-leaved Red..

White Cryftal:

Large Pale and Red Dutch.

ax

The 
The Currant is the mont ufeful of all the fmall fruit, either for the table and kitchen, or for preferving, making wine, \&c. and continues longer in fucceffion than any other. With proper management, Currants will continue in ufe from June to November. Black Currants are very much efteemed by fome; yet they are feldom fent to the table, but are very ufeful for making jelly, frequently taken for fore throats, colds, \&c. *

\section{On the Propagation of Currants.}

Currants may be raifed from feed, layers, \&zc. When the trees are cut low, you may lay down fome of the branches either in Winter or Spring, when the ground in the quarters or rows is dug, which hould always be done annually. In the Autumn following, thefe layers will have made fine roots; you may then plant them ont where you wilh them to ftand, and they wili bear fine fruit in the following Summer.

Currants may alfo be propagated by cuttings, as Goofeberries; always remembering to make choice of the ftrongeft and fraighteft thoots.

* In Ireland, Black Currants are frequently fteeped in whifky, of which they make pench, and recommend it as a goed medicine for coughs and colds. I once had two gallons of it fent me by a friend for that purpofe; fome of it was taken in a glafs of warm water by a pexron who was very much as to be in a decline, which effected a perfect cure in three or four nights.

The Currants, for this purpofe, Thould be bruifed and put in a jar, and the whilky poured over them: let it ftand for a week or fortnight, covering it clofe down; then frrain it through a fine cloth or fieve, and put it in bottles or canks for ufe. Currants may be ufed in this manner with brandy, gin, or any other fpirits. They may alfo be prelerred as Cherries, and fent up to table.

Under 
Under the buthes that have been covered for late fruit you will always find plenty of felf-fown plants, which I would advife you to plant out by themfelves. Thofe who makeCurrant-wine may fave the feed, after the fruit is fqueezed, and dry it: it may then be fown in Autumn, or early in the Spring, on a bed of fine light earth ; by which you will, moft probably, obtain fome fine varieties. By no means propagate them from fuckers, as they never grow handfome, and are very liable to throw out a great many fuckers.

In many gardens there ftill remains a fmall fort of red and white currant not worth cultivating; I would therefore advife thofe who have any of them in their gardens to root them up, and plant, in their room, the large Red and White Dutch, the long-bunched red, and Champagne large Pale Red. Currants may be planted out in the fame manner as. Goofeberries, either in quarters or fingle rows round the edges. of quarters.

I would particularly recommend planting a few againft a South or Weft wall, or paling, which will produce fruit much earlier than in quarters, \&c. Alfo to plant fome between. other fruit-trees on North walls, or palings, for latter crops:; thefe may be covered with double nets, to proferve them from birds; tucking in a few fern branches batween the two nets, which will prevent the heat of the fun and drying winds from fhrivelling the fruit. In quarters they thould be covered 'with. mats.for the fame purpore; at the fame time permitting all the leaves to remain on the buthesz: to Shade the fruit and: make it keep the longer. 


\section{Pruning of Currant-Bufles.}

The pruning of Currants is nearly fimilar to that of Goofeberries. You may begin in the Month of November, and continue till March, as it fuits your convenience.

Currants thould never be left too thick of wood; and a great deal depends on the management of them in Summer, to have ftrong and fine wood for the following Seafon. If they have been neglected for fome years, and fuffered to run up to long naked wood, they mut be cut down near the ground; they will then fet forth fine ftrong thoots. In this cafe, I would recommend heading down every other tree, and cutting the others partially, by taking out every other branch as near as can be to the ground, unlefs they are trained up with fingle ftems, in which cafe it will be neceffary to cut them as near as poffible to where the branches begin to break out and form the head.

In the Winter pruning, you mut preferve the ftrongef and finelt Shoots, leaving them from nine to eighteen inches long, according to their ftrength, and from eight to ten inches apart, and as regular as poffible from top to bottom of the tree; taking care to cut out all the dead and weak thoots, Pay particular attention in Summer, and keep the middle of the bufh open to admit the fun and air ; preferving the fineft and ftrongeft thoots that are neareft the ftem. Some are fond of training them up with fingle ftems, to a confiderable height, to form fine round heads, which are very ornamental, if not fuffered to run up too high: as in that cafe they are liable to be broken by the wind, if not well fupported by itakes. 
Atakes. Care muft be taken not to let the fhoots run to more than fix inches long; becaufe fuch thort thoots will not be fo liable to be damaged by the wind as long and weak ones: are, efpecially when loaded with fruit. I prefer dwarfs from three to four feet high.

The fame manner of pruning, Bxc. will do for Black Currants; but, as they grow fronger than the Red or White, the thoots fiould be left thinner, and laid in longer, which will make them produce larger and finer fruit.

Thofe againt walls and palings thould have the thoots laid in thinner than thofe in the quarters, and trained as horizontally as poffible, thortening them in the Winter pruning to a foot or eighteen inches, according to the ftrength of the thoots.

As Currants are very liable to be devoured by earwigs which take thelter under their leaves and branches, bundles of bean-ftalks fhould be hung up fome time before the burhes are covered with mats or nets. If proper attention be not paid to this, the fruit will generally fuffer very much from thefe infeets. After the burhes are covered, take the mats off once in three or four days, and kill the earwigs that have got into the bean-ftalks, which it will be neceffary ftill to keep hung up. As there is a fweetnefs in the infide of beantalks which attracts the earwigs, they very readily take Thelter in them from rain.

By paying proper attention to the foregoing directions, you will be able to keep thefe deftructive infects under, and preferve the greater part of the fruit.

Be particularly careful to ftock up all fuckers at the roots of the trees, and keep them as clean as poffible; otherwife the 
the fuckers will prevent the fun and air from penetrating to the roots, and greatly weaken the trees.

What has been faid above will, I hope, be fufficient to direct thofe who are fond of cultivating this valuable and ufeful fruit.

Currant's are very liable to be inferted with aphides and other infects, which thall be taken notice of in anotherplace. 


\title{
CHAPTER XIV.
}

\author{
OF RASPBERRIES.
}

Different Sorts of Rafplerries; and of Propagating, Planting, Watering, Stuking and Pruning them.

RaspBerRies are a very ufeful fruit for the table; for preferving, for making of jam, fauce, \&c. and continue a long time in bearing.

The Rafpberry belongs to the fifth order of Linnæus's twelfth Clafs, Icofandria Polygynia, and is a native of England.

The following are the Sorts cultivated in this Country.

Early White:

Large'Red Antwerp.

Double bearing White. Large White Antwerp. Large Common White. ". Smooth Cane Doublembearing. Large Red. Woodward's new Rafpberry. 
Of Propagating, Planting, and Pruning, Rafpberries.

Rafpberries are raifed from fuckers and layers.

They fhould be planted in a piece of ground by themfelves, and (except the Early White) at the: diftance of about fix feet from row to row, and four feet in the rows.

The ground thould firft be well trenched and dunged, before the Rafpberries are planted. Make choice of the ftrongeft and fineft plants that come out from the fides of the ftools, where they have been ftanding for fome years; or encourage the Atrongeft plants that come out betwixt the rows after digging, which thould be done annually. In digging the ground, you will frequently happen to cut the roots with the fpade, which will occafion a great number of fmall plants to come up; of thefe felect the ftrongeft and fineft, and hoe up all the fuperfluous ones. But I prefer laying down fome of the ftrongeft outfide fhoots in the month: of March; as by the following: Autumn they will make fine: roots, and may be planted out in a quarter or piece of ground: where you intend them to remain. Thefe will not be fo: liable to throw out fuckers as thofe which are produced from. fuckers.

When you plant out frefh pieces of Rafpberries, it fhould: be done in moift weather, as the roots are very delicate, and liable to be hurt when expofed to a dry air. If, however, they are planted in dry weather, take care to moiften the roots with water, and cover them with wet litter, or leaves, during the time of plapting. 
In planting, open a trench with the fpade along the line where the fuckers or layers are to be planted; cut off all the fmall fibry roots with a knife, leaving only the ftronger roots; put them into the trench, and cover them with fome earth; then water them well, and throw the remainder of the earth over them, letting them remain till you have finifhed planting the piece; then, where you firft began to plant, begin and tread the ground with your foot as hard as you can along each of the trenches, and in the fame direction as you planted: then with a fpade level all the ground fmooth, and run it over with a rake, taking off any ftones and rubbith that may be left on the furface.

In dry weather, the plants fhould be watered two or three times a week till they have taken root. It will be neceffary to ftake the Antwerp, and other ftrong-growing forts, with ftout ftakes; then run a couple of fmall rails at top, to tie the branches to; which will prevent their being broken by the wind, or beaten down by the rain. The Early White and fmaller forts may be plaited together at top, tying them round with the fmall yellow willow, which will keep them together. Some of the Early Rafpberries may be planted between the trees on a Weft afpect, to produce early fruit before thofe in the quarters come in. The Antwerp will thrive exceedingly well againft North walls or palings, and will produce late crops. Such as are planted againft walls or palings fhould be tacked to them.

Where you find any of the fmall Red and White Rafpberries, deftroy them, and plant the following forts in their room; viz. the Large Red, the Smooth Cane Double-bearing, the Large Red and White Antwerps, the Large Common

White, 
White, the Double-bearing White, and Woodward's New Rafpberry.

Some prefer pruning Rafpberries in Autumn, a practice of which I by no means approve. As they bear the fruit on the wood of the preceding year, they are very liable to be killed by the froft in fevere winters; but, by deferring the pruning: till the month of February, you will have great choice of fine wood for bearing the following Summer; remembering to root out, or cut down, all the wood that bore fruit the preceding year, which generally dies; felecting only from five to feven of the moft vigorous and ftrong thoots from the laft year's wood, to bear fruit the enfuing feafon. Thefe thoots may be pruned to the length of three or four feet according to their frength, if they are of the Smooth Cane Doublebearing fort (which generally bears a fecond crop in Autumn, and will in fine feafons continue bearing from June to November); but, if the large Antwerp, the fhoots fhould be left five or fix feet long.

The Early White, which never grows fo ftrong as the above forts, fhould be thortened to two feet and a half, or three feet. Thefe thould be planted in rows about three feet diftant from each other, and two feet from plant to plant in the rows; always remembering to keep them clear of fuckers, and to cut out the dead, or laft year's wood, as before directed; making choice of the ftrongeft thoots for bearingwood. But be careful not to cut off the little fpurs on the fides, which bear the fruit.

Rafpberries will continue in bearing five or fix years; by which time you fhould have a freth plantation to fucceed them. The young plants will bear fome fruit the firft year, 
and come into full bearing the fecond year after planting. If they be fuffered to remain more than five or fix years on the fame ground, they will degenerate and bear fmall fruit. Care fhould be taken not to leave above eight or ten of the ftrongeft thoots, rubbing off or pulling up all the fuperfluous ones; and to keep the ground well hoed and clear of weeds between the rows. 


\section{CHAPTER XV.}

OF BARBERRIES.

The Different Sorts, and their Culture.

THE Barberry is ufeful for preferving and pickling, and for garnithing of difhes; the trees alfo have a fine effect in thrubberies and pleafure grounds, being beautiful flowering fhrubs. In Autumn and Winter they have a delightful appearance, from their various-coloured fruit. I would, therefore, recommend planting them in all thrubberies and pleafure grounds. Thofe who are fond of the natural harmony of finging-birds will find Barberries well adapted for attracting them to the fpots where they are planted, moft birds being very fond of them. They fhould not, however, be planted near the fides of public walks, as the flowers emit a very frong and rather difagreeable imell.

The 
TREATISE ON THE CULTURE, \&c.

The Barberry is ranged, by Linnæus, in the firft order of his fixth Clafs, entitled Hexandria Monogynia.

The following Sorts are moft efteemed for their Fruit, viz.

I. The Red Barberry without Atones, which has an agreeable flavour when full ripe.

2. The White Barberry.

3. The Black Sweet; which is the tendereft of them, and fhould be planted in a warm fituation.

4. The Common Red with ftones. This is planted more for ornament than ufe, on account of its beautiful red berries.

The Barberry is a native of England.

\section{Of Raifing and Pruning. Barberries.}

Barberries are very eafily propagated from fuckers and layers, and require the fame management in pruning as other flowering fhrubs. I would always recommend planting them in pleafure-grounds, and not in kitchen-gardens. On grais lawns, in pleafure-grounds of fmall extent, they have a fine appearance, and are frequently planted in fuch fituations as ornamental flowering thrubs; they are alfo planted frequently in clumps.

When you wifn to increafe them, encourage the finent and cleaneft Thoots in Summer, by trimming all the fide branches off thin; and when you drefs the Shrubberies in Winter, lay 
TREATISE ON THE CULTURE, \&c。

down the ftrong thoots, which will take root, and be fit to tranfplant in Autumn following. When defigned for ufe, they fhould be trained up as ftandards and half ftandards, and they will grow from fix to twelve feet high. In Summer, trim off all the ftraggling and fuperfluous fhoots; fo as that they may make fine handfome heads.

Barberries may alfo be raifed from feed; but fuckers and layers are beft for preferving the forts diftinet. 


\title{
CHAPTER XVI.
}

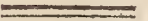 \\ OF MULBERRIES.
}

Different Siorts cultivated in England-Propagating, Planting, and Pruning of them-Of Reftoring old and decayed Trees.

\begin{abstract}
THE Mulberry, Morus, is a native of Perfia; whence it was introduced into the Southern parts of Europe, and is now commonly cultivated in England, Germany, and other countries where the Winters are not very fevere. It is ranked in the fourth order of Linnæus's twenty-firft clafs, Monocia Tetrandria.

We are informed, that Mulberries were firft introduced into this country in 1596 ; but I have reafon to believe, that they were brought hither prior to that period, as many old trees are to be feen ftanding at this day about antient monafteries and abbeys; from which it is at leat probable, that they had been introduced before the diffolution of thofe houfes.
\end{abstract}


Four large Mulberry-trees are fill ftanding on the fite of an old kitchen-garden, now part of the pleafure-ground, at SionHoufe, which, perhaps, may have ftood there ever fince that houfe was a monaftery. The late Duke of Northumberland has been heard to fay, that thefe trees were above 300 years old.

At the Priory near Stanmore, Middlefex (the feat of the Marquis of Abercorn), there are alfo fome antient Mulberrytrees. The Priory was formerly a religious houfe.

In a very old garden at Chelfea, which belonged to the late John Browning, efq. (who was a very good botanift, and had a large collection of trees and plants) there is one of the largeft Mulberry-trees that I ever faw, and which appears to be extremely old.

Gerard, who publifhed his Hiftory of Plants in 1597 , fays, in that book, that Mulberry-trees then grew in fundry gardens in England.

\section{Thofe commonly cultivated in this Country are,}

I. The Common Black Mulberry-tree, which is much efteemed for its delicate fruit. This is now common in moft parts of Europe, except where the Winters are very fevere. There is a variety of this with jagged leaves, and fmaller fruit; but Mr. Miller fays, that it is a diftinot fpecies, a native of Sicily; and that the fruit has no flavour ; confequently, it is not worth cultivating. There were fome of thefe trees in Chelfea-gardens.

2. The White Mulberry. This tree is raifed in great abundance in Italy, and other fotthern countries, for the leaves, 
leaves, to feed filk-worms*; though it is faid that the Perfians generally ufe the Common Black Mulberry for that purpofe; and this latter is the only fort raifed for the fake af its fruit, which is very wholefome.

3. The Red or Virginian Mulberry-tree, which grows to a confiderable height, and bears reddith berries.

The two laft are cultivated, in this country, only for the fake of variety.

Mulberries are raifed from feed, or propagated from cuttings and layers.

Thofe raifed from feed have frequently male flowers, and produce no fruit; thefe, therefore, thould never be made choice of for fruit-bearing trees, unlefs they have been feen to bear in the nurfery.

The beft bearing branches of old trees are to be chofen for cuttings and layers; for fome branches of thefe trees produce only katkins, and trees raifed from them will never produce fruit. If they are to be raifed from layers, they will generally take root fufficiently the firft year to bear feparating from the parent tree, and thould then be planted in a nurfery, and trained up with fingle ftems. In four years they will be fit to plant out where they are to remain. They hould be planted at a proper diftance to admit the fun and air, as the fruit, when the trees are too clofe, is very apt to turn mouldy; they fhould alfo be fheltered from the Eaft, North, and Wef winds.

But the beft way of raifing Mulberries is from cuttings of the former year's thoots, having one joint of the two years

* This tree poffeffes the peculiar property of breeding no vermin, either while growing or when cut down; neither does it harbour any caterpillar, the filk-worm exwepted. Evelyn's Sylva, by Hunter, Vol. II. p. 40. . 
wood. Plant them out in Autumn, if fine weather, or in the month of March, in rows nine inches apart, and at the diftance of two inches in the rows, leaving only two or three buds above ground: mulch the ground with leaves or dung well rotted, to keep it moift, and the plants will require little watering. If they fucceed well, they may, next feafon, be tranfplanted into a nurfery, and treated as directed for layers. Thefe young trees, while they remain in the nurfery, thould be tranfplanted every three or four years.

I would recommend planting of Mulberries in grafs orchards and pleafure grounds, becaufe the fineft of the fruit, when ripe, frequently drops, which, if it fall on dug or ploughed ground, will be foiled and rendered unfit for ufe, as the earth will adhere fo to the fruit as to render the cleaning of it impracticable; but if planted on lawns, or in grafs orchards, the fruit can be picked up without receiving any injury. Another reafon for planting thefe trees on lawns or in orchards is, that, when full grown, they are too large for a kitchen garden. The foil in which they thrive beft is a rich, light, and deep earth.

As the fruit is produced on the young wood, you thould cut out only fuch branches as crofs others, and fuch as are decayed, or broken by any accident; at the fame time apply the Compofition. If, however, the heads fhould become too full of wood, it will be neceffary to thin them, as the fruit is larger and better flavoured where the heads are kept thin of wood.

I have found many of thefe trees in a very decayed ftate, with the trunks quite hollow; and have tried the efficacy of the Compofition on feveral of them, cutting out all the dead. wood and cankery parts of fome, and heading down others 
that were funted and fickly. After thefe operations they put forth vigorous branches, and bore excellent crops of fruit, more than double the fize of that which they produced in their former ftate.

I would advife thofe, who have any old decayed Mulberrytrees, to treat them in the fame manner; but thofe which are very much decayed thould be headed down; this will throw them into a healthy bearing ftate, and in two or three years they will produce plenty of fine fruit.

In the lawn in front of the houfe of John Grove, efq. at Little Chelfea, there are four old Mulberry trees, which a few years ago were fo very much decayed, and fo full of wounds and dead wood, that they produced very little fruit, and that of a fmall fize. I had all the decayed and rotten wood carefully cut out, and the branches trimmed, and then the Compofition applied. In the firft feafon they fent forth fine fhoots, and in the fecond produced plenty of fruit, of a better flavour, and double the fize of that which they formerly bore.

As old Mulberry-trees produce, not only a greater quantity of fruit, but alfo much larger and of a finer flavour, than young ones, it is well worth while to take fome pains to repair the injuries which they may have fuftained by accidents or age.

I am forry to fay, that this pleafant and valuable fruit is but very little cultivated in this country*.

* Gerard, in his defcription of the Mulberry-tree, has the following curious paragraph : "Hexander in Atheneus affirmeth, that the Mulberry-trees in his time did not bring" forth fruit in twenty years together; and that fo great a plague of the gout reigned and raged fo generally, as not only men, but boys, wenches, eunuchs, and women, were troubled with that difeafe." 


\title{
CHAPTER XVI.
}

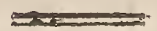 \\ OF THE SERVICE.
}

The Cultivated Service, the Wild Service, and the Maple-leaved Service: reith their Culture.

THERE are three forts of the Service-tree cultivated in England, viz. the Cultivated Service, the Wild Service, or Mountain-Ath, and the Maple-leaved Service. The firft is a native of the warmer climes of Europe; and the other two. grow wild in different parts of England.

The Service belongs to the twelfth Clafs of Linnæus's Syftem, entitled Icofandria Trigynia.

\section{Of the Cultivated Service.}

This tree is well worth cultivating, both for its fruit and for ornament. It is beautiful in the month of June when in. flower 
flower, and the fruit in Autumn has a fine appearance, and. grows to a large fize if the trees be kept thin, and not overloaded with wood. They may be planted in orchards among. other fruit-trees; for; as they flower much later than Apples. and Pears, there will be no danger of the farina intermixing. with theirs. They may alfo have a place in plantations in the pleafure ground, or fingly on the lawn, or in rows by the fides of gravel-walks: in this cafe, they thould be trained. with ftraight ftems eight or ten feet high, and all the ftraggling branches fhould be cut in, to affift them in forming handiome round heads. Thefe trees may be intermixed with. thorns, and will have a very good effect.

We have only two forts cultivated in the garden; viz, the Apple-thaped, and the Pear-Ihaped Service-tree.

Thefe trees are propagated from feed, layers, and cuttings. By raifing them from feed you may perhaps obtain feveral varieties; but the beft method of preferving the forts, when you have fine varieties, is by grafting or budding:

Train the ftem, if for ftandards, fix or eight feet high; but if for dwarfs, about three feet $\mathrm{l}$ gh; which latter may be planted in Mrubberies. The fruit, when ripe; may be gathered and put in the fruit-room; letting it remain till. nearly in a fate of decay: it will make a variety when ferved up to table among the Autumn fruits.

The wood of this tree is very ufeful for making picture frames, toys, \& 2 .

When the trees are pruned, and where there are any de-cayed parts, the Compofition thould be applied. 


\section{Of the Wild Service-Tree, or Mountain Aft.}

The Wild Service is fometimes planted in orchards among fruit-trees; but I would recommend planting it in pleafure grounds, plantations, or on lawns, for ornament, where the different varieties of the fruit have a beautiful effect in Autumn; and the fruit gathered, when full ripe, and laid by fome time to foften, has a very agreeable acid tafte.

The feeds, when properly dried, may be fown in Autumn in beds of light mould; taking care to keep them free from weeds in Summer. In the following Autumn they may be tranfplanted into beds, or quarters (according to the number which you may with to plant), and trained either for dwarfs or ftandards.

By felecting the largeft and fineft fruit many varieties may be obtained from the feed; they may alfo be propagated from layers; but thofe who are fond of having a great variety, and keeping the forts true, fhould graft them.

If trained up with ftraight clean ftems, Service-trees will grow to the height of thirty or forty feet; in that cafe they fhould be planted among foreft trees, or in the back parts of large fhrubberies. But thofe who wih to plant them as flowering thrubs muft head them down when young, to make them throw out horizontal fhoots; they may then be planted among the middling-fized Mrubs, which will make a beautiful variety, both when in flower and when bearing fruit.

Wild Service-trees* grow to a confiderable fize when pro-

* The fruit of the Wild Service is excellent food for Game and other birds. 
perly managed, and are very much ufed by wheelers, \&c. on account of the wood being all, what they call, heart-wood.

\section{Of the Maple-leaved Service-Tree.}

This tree grows wild at Paddington, and in other parts of England, and is frequently forty or fifty feet high, with a large. fpreading head, making a fine appearance, and deferves a place among foreft-trees and in extenfive plantations and gardens. It bears large bunches of white flowers, fucceeded by clufters of brown fruit, which, when gathered full ripe, and laid by for fome time, till it becomes foft, has a very agreeable tart flavour.

This tree may be raifed from feed, which fhould be fown in : Autumn, or by layers; but thofe who winh to raife them in the dwarf ttate thould graft them very low, and train them from fix to eight feet high. Some graft them on whitethorns; but I prefer their own ftocks. If thefe dwarfs are trained up with fine heads, they will have a very good effeet: in thrubberies. If intended for ftandards, train them up as high as you can: they will have a beautiful appearance in the back parts of thrubberies. They may alfo be trained without grafting, and planţed on lawns for ornament. Some train them as Efpaliers; but this I do not approve of, as they are not fo ornamental, neither do they bear fo well.

The wood of this tree is alfo very ufeful for mechanical purpofes. 


\section{CHAPTER XVII.}

\section{OF THE ALMOND.}

Different Sorts of Almonids; their Propagation, and the Method of Pruning them-How to keep them during Winter.

THE Almond belongs to the twelfth Clafs of Linnæus, Icofandria Monogynia, being joined with the Peach, and was introduced here in 1570 .

Almonds are beautiful trees for planting in Thrubberies and plantations, and deferve a place in every pleafure-ground, on account of their coming fo early into bloom, and for the ufe of their kernels.

The following are the Sorts propagated in this Country for Ornament and USe, viz.

The Tender-Thelled Almond; the Sweet Almond; the Common or Bitter Almond; the Sweet Jordan Almond; the Hard. 
Hard-thelled Almond; the Divarf, and the Double-flowering Almonds. The laft two, being beautiful early flowering fhrubs, are planted for ornament only.

Almonds are propagated by budding them upon Plum, Almond, or Peach ftocks. The next Spring you may train them for ftandards, or let them grow for half ftandards; but the common way is, to bud them as high as you with the ftem to be ; and the fecond year after they may be planted out for good. If you are to tranfplant them into a dry foil, let it be done in October, when the leaves begin to decay; but if into wet ground, the month of February is the proper feafon. Almonds budded on Plum-ftocks thrive beft in a wet foil, and on Almond and Peach ftocks in a dry.

When the young trees are brought from the nurfery, they fhould never be cut till the young thoots begin to break, as directed for Peaches and Nectarines.

Almonds require nearly the fame management in pruning as ftandard Apricots. After wet Autumns, when the wood is not well ripened, hard Winters are apt to kill the fhoots; in that cafe, they thould be cut down to the found wood; taking care to cut out the crofs fhoots that rub againft others, leaving the tree open in the middle, pruning the fhoots about the fame length as Apricots, and according to their ftrength. Never omit cutting out all the cankery parts, and decayed wood.

Some plant thefe trees out as ftandards, and others as halffandards, according to the ground and fituation; always taking care to plant them in a fheltered place facing the South, intermixing them in the back of the fhrubberies with the taller flowering thrubs: or they may be planted on lawns for ornament, as they make a very beautiful appearance when

A A in 
in flower, or bearing fruit. If planted as dwarfs, they may be covered with poles ftuck into the ground, thatching over the tops of the trees with fome fern, or any other light covering, which will prevent the bloffom from being killed by the froft in February and March. A fter the fruit is fet, and the leaves fo far out as to cover it, if fine weather, the covering may be removed in the latter end of April or beginning of May, which will enfure a plentiful crop of Almonds; a very ufeful fupply for the table in Autumn and Winter.

Thofe who have plenty of walling fometimes plant Almondtrees on walls, and fometimes on efpaliers.

Almonds may be preferved in dry fand, or bran, for ufe; but they mut be thoroughly dried on thelves, or boards, in an airy place before they are put into the fand or bran, otherwife they will get mouldy. They are preferved only for their kernels, the other part of the fruit being of no fervice. 


\title{
CHAPTER XIX.
}

\author{
$=$ \\ OF FILBERTS AND HAZLE-NUTS.
}

The Sorts commonly cultivated in England-Method of CultureHoro to keep them in Winter.

Filberts and Hazel-nuts grow wild in woods and hedges, and are brought in great quantities to the London markets, and to thofe of other large towns throughout the kingdom; employing a great many poor families during the Autumn, who otherwile might have very little to do, and of courfe be a burden on the publick.

This genus of plants is ranged in the eighth order of Linnæus's twenty-firft clafs, Moncecia Polyandria.

The Sorts generally cultivated in England are the following, viz.

I. The Large Cob-nut.

2. The large long Nut, which produces very fine large fruit. A A 2

3. The 
3. The Barcelona, or Spanifh Nut, with large cups.

4. The Common Wood-nut, with red-fkinned kernels.

5. The Filbert with white kernels.

6. The Fiibert with red kernels.

7. The Large Clufter Wood-nut.

\section{Of Propagating and Pruning Nut-Trees.}

Filberts and Nuts of all kinds are propagated from feed, layers, and fuckers; but thofe who with to have fine forts thould graft the trees, or lay down in March fome of the ftraighteft thoots, notched at a joint, pegging them into the ground; then cover them with earth about three inches thick, making bafins round them with edges of mould about two inches higher than the furface of the ground, to prevent the water's running off; water them fometimes in dry weather, and mulch them with fome rotten leaves, to keep them moint. By the following Autumn they will be fit to take up and plant out in beds in the nurfery, where they fhould remain about two years, planting them out in Augult where you wifh them to remain for good. If any of the layers have not taken proper root, they may be left till the Autumn following.

Filberts and Nuts may be planted on the outfides of woods, or in the back parts of fhrubberies and pleafure-grounds, or in large kitchen-gardens, in thady walks; or for the purpole of hiding theds, cifterns, \&c.

When they are raifed from feed, it thould be fown in Autumn, in a light earth; and it will be neceffary to cover the beds all over with flates, flat ftones or bricks, to prevent 
the mice from eating the Nuts or carrying them off in Winter.

When at the Botanic Gardens, Chelfea, I once fowed feveral quarts of large Barcelona Nuts, in pots, in two frames at a confiderable diftance from each other, the Nuts were all carried off by the mice in one night. On fearching round the lining of a frame where we kept green-houfe plants in Winter, I found above a quart of the Nuts in one hoard, which I again fowed immediately, covering them over with flates; from thefe Nuts I raifed fome very fine plants.

The Barcelona Nut-tree is rather fcarce in England, but it is well worth cultivating; it is a diftinct fpecies, and grows to a fine timber tree. The Nuts that I fowed, as mentioned above, were produced from a fine tree in the Botanic Gardens at Chelfea *.

Thofe who are not in poffeffion of plants may procure them from Nuts frefh imported from Spain, by fowing them as before dirested. Great quantities are imported annually under the name of Barcelona, or great Spanifh Nuts.

When in the Nurfery, Nut-trees thould be trained with fingle fraight ftems, to form fine heads from three to fix feet high; cut off the leading-fhoot at the height you would have the head formed, rubbing off all the lower buds, and leaving only as many at top as you think will be fufficient to form a handfome head, and according to the ftrength of the ftem.

* This tree, at two feet and a half from the ground, meafures about four feet in circumference.

Nuts, 
Nuts, when intended for keeping, thould be well-dried and packed in jars or boxes of dry fand (and placed in a fruit-room, or dry cellar), well covered down to preferve them from mice.

The hoots of Filbert and Nut-trees are very ufeful for ftaking green-houfe plants and rafpberries, or for making withes to bind fagots, and for many other purpofes in hurbandry. 


\section{CHAPTER XX.}

OF CHESNUTS.

Different Sorts cultivated in England-Chefnut-Trees are excellent Timber-Hore to Propagate, Plant, and Head them.

THE Chefnut, Caftanea, is a native of the South of Europe, and is faid to take its name from Caftana, a city of Therfaly, where antiently it grew in great plenty. It belongs to Linnæus's twenty-firft clafs, Moncecia Polyandria.

The forts moftly cultivated in England are thofe commonly called Spanifh Chefnuts, which run into great varieties when raifed from feed; and a fort called, in America, Chinquapin, or Dwarf Virginian Chefnut; but this is only raifed for the fake of variety.

The former are very fine trees, and well worth cultivating both for ufe and ornament. The timber is reckoned equal to Oak, and, for making cafks, even fuperior to it; as, when feafoned, it is not fo liable to Mrink or fwell as Oak. Thefe 
trees have alfo a very noble appearance, and are therefore very fit to plant in parks, \&c.

Gerard fays, that in his time there were feveral woods of Chefnuts in England, particularly one near Fevertham in Kent; and Fitz-Stephens, in a defcription of London written by him in Henry the Second's time, fpeaks of a very noble foreft which grew on the North part of it. This tree grows fometimes to an amazing fize. Not to mention thofe abroad, there is one at Lord Ducie's at Tortworth, in the county of Gloucefter, which meafures nineteen yards in circumference, and is mentioned by Sir Robert Atkyns, in his Hiftory of that county, as a famous tree in King John's time; and by $\mathrm{Mr}$. Evelyn, in his Sylva, book 3 d, chap. 7, p. 232 , fourth edition, to have been fo remarkable for its magnitude in the reign of King Stephen, as then to be called the Great Chefnut of Tortworth; from which it.may reafonably be fuppofed to have been fanding before the Conqueft. Lord Ducie had a Drawing of it taken and engraved in $I 77^{2}$. One of the prints is now in my poffeffion, and was a prefent from my muchefteemed friend, the late Captain William Lockyer, of the Royal Navy, and Lieutenant-Governor of Greenwich Hofpital * Formerly a great part of London was built with

* At Anted-park, near Epfom, the feat of Richard Howard, Efq. there are a great many Spanin Chefnuts, that were fown by a gardener now living, one of which, at three feet from the ground, meafures feven feet in circumference, and has a trunk upwards of fifty feet high.

Since writing the above, I have feen the old gardener, Thomas Davie (who is now 77 years old), and have had fome converfation with him. He fays, that at the age of 15 be bought three fhillings-worth of Chefnuts in London on purpofe to treat his fellowfervants; but finding that they would not accept of them, he fowed them in a bed in the garden at A thted, which then belonged to the Earl of Suffolk, and afterwards planted * out the young trees where they now ftand. Thefe trees are, therefore, at this time fixtytwo years old; from the feed.

Chelnut 
Chefnut and Walnut-tree; and at Sion Houfe, the feat of the Duke of Northumberland, the ftables are built with them, from the old monaftery at that place, which was taken down when the prefent manfion-houle was built.

The beft way of propagating Chefnut-trees is from feed, gathered when thoroughly ripe; which is generally about the latter end of October; but they fhould not be gathered till the huks begin to open, and the Nuts appear of a brownith colour; they will then drop of themfelves, and fhould be carefully picked up in the morning; and particularly after high winds; thofe which are intended for eating, or for feed, thould be always fuffered to drop of themfelves; they will be found much better than thofe that are beaten down. If, however, the froft thould fet in early, you will be under the neceffity of thrafhing them down, which fhould be done in a dry day. All that fall in the hufk fhould be thrown in heaps in a thed, or other convenient place, and fuffered to remain three weeks, or a month, in that ftate; to ripen. They thould then be taken out of the hufks, and the beft picked out and laid up by themfelves, after being welldried, on mats, or cloths, in a funny fituation. They hould be laid up in the fruit-room, or granary, on thelves, or on a dry floor. Remember to turn them frequently. The inferior ones will do for fowing, or they may be given to pigs or turkeys, who are very fond of them; they will be found very good for fattening poultry, efpecially turkeys. If during the Winter they thould become damp or mouldy, they thould be turned and carefully wiped; and if fpread at a moderate diftance from a fire, or dried in an oven after the bread is drawn, and then packed in boxes, or jars, with thorough dry fand, they will keep plump and good. Obferve not to 
put them into the oven when too hot, as it will make them fhrivel: and thofe for fowing mutt not be dried in this manner, as the heat of the oven would kill the germ. In a fine warm feafon, I have feen them ripen as well and grow nearly to as large a fize as foreign ones, when the trees were healthy; but in a middling feafon they will do very well for fowing, or for fatting pigs and poultry. Be careful to preferve them: from rats and mice, otherwife they will foon defroy vaft quantities of them.

They may be fown in beds of light earth in the month of November, if it be a dry Autumn, drawing the drills about nine inches apart, and about three deep. Plant the Nuts. about an inch apart in the rows, with the points upwards, as bulbous roots are planted; then cover them with mould, and pat it down with the back of your rake. The beds thould be four or five feet wide, and a little raifed towards the middle, to carry off the water. There fhould be alleys between the beds, about eighteen inches wide, and about two or three inches deep; thefe will receive and carry. off the rain-water, which otherwife would be apt to rot the Nuts. Thus, a five-foot bed will admit of fix rows and a fmall edging next the alley. If you find the mice begin to attack them, the beds thould be completely covered over with flates, fat ftones, or bricks, till the Nuts begin to fpring; they muft then be taken off. If it be a hard Winter, it will be neceffary, before the ftones or tiles are put on, to cover the beds with fome rotten dung, rotten leaves, or old tan, to preferve the Nuts from the froft. If it be a mild Winter, and the Nuts have been fown in Autumn, they. will begin to vegetate before Chrifmas; but if the Autumn be wet, I would advife. not to fow them till fome time in February, or the beginning 
of March. By the Nuts being fown in rows, you will have room to hoe betwixt the rows, and be able to keep them clear of weeds, which you could not fo eafily do if they were fown broadcaft. If it fhould prove a very dry Summer, it will be necelfary to give them a good watering once or twice a week, till the plants begin to get firength. If they be well managed, by the end of October, or in the following Spring, you may tranfplant them into beds, in rows about a foot apart, and at the diftance of four inches in the row, where they may remain for two years longer; taking care to trim all the fidethoots, leaving only one fraight ftem. Thefe beds may have alleys about the fame width as before, with this difference, that the beds fhould be two inches lower than the alleys, which muft be well trodden, to keep the earth from crumbling down into the beds. Firft level all your ground, then ftretch the line from one end of the bed to the other, according to the fize of the ground, and with your fpade cut off the edging in the infide of the bed, throwing the mould towards the middle of it: then remove the line to the other fide of the bed, which ought to be from four to fix feet wide, and cut the other edge, throwing the mould into the bed as before. When this is done, throw up fome of the mould on the top of the alley, to make it about two inches higher than the bed, and tread the alley well down. Then begin to plant. your young trees in rows acrofs the bed, a foot or fifteen inches apart, and about fix inches in the row, digging the ground and planting as you proceed, alfo beating.up the edges of the alleys with the back of your fpade, to keep the mould from tumbling down into the bed. Proceed thus till you have finithed the bed, and fo on till you have planted the whole. If it be dry weather, each bed fhould be watered as В в 2 
you finih planting it, which being made a little lower than the alleys will retain the water that you throw on it, and will prevent the rain from running off : if the dry weather continue long, mulch the beds as before directed. Obferve to keep them free from weeds, watering them as occafion requires, and trimming up the plants with only one ftem. In this ftate they may remain two years, and, if any of the plants. require it, fake them to keep them ftraight. At the end of two years they will be fit for tranfplanting, and may be planted out for good, if they are properly fenced off from cattle; but if they are to be placed in an open expofure, they ought firft to be planted out in a piece of ground, properly prepared for the purpore, at the diftance of two feet from row to row, and one foot in the row. If they have been planted in the Autumn (which I would always recommend, except in wet ground, or when the feafon is wet) let them remain till next Spring twelvemonth, and then head them down to two eyes above ground, cutting as near as may be to an eye, and floping to the North, that the thoot which is thrown out may cover the ftem in the firft feafons. which, if the bufnefs be rightly performed, it will do, and grow to the length of fix or feven feet, according to the vigour of the ftem. If they are not headed down in this manner, you will never have fraight handfome trees. If the ground be properly fenced off from cattle, thofe that are planted out for good, at three years old, muft be treated in the fame manner after the firft or fecond year. It may, however, be neceffary to obferve, that young trees muft not be headed down immediately after tranfplanting; they ought to be well rooted before that operation is performed; and it is alfo worthy of remark, that, the larger the ftems 
are when they are headed, the ftronger and more luxuriant will the fhoots be.

I did not, at firft, intend to have faid any thing of Chefnuts and Walnuts; but, as mort people are fond of them, and as they are generally ferved up at table with the deffert, it feemed proper to give fome account of their culture, \& $\mathrm{c}$. 


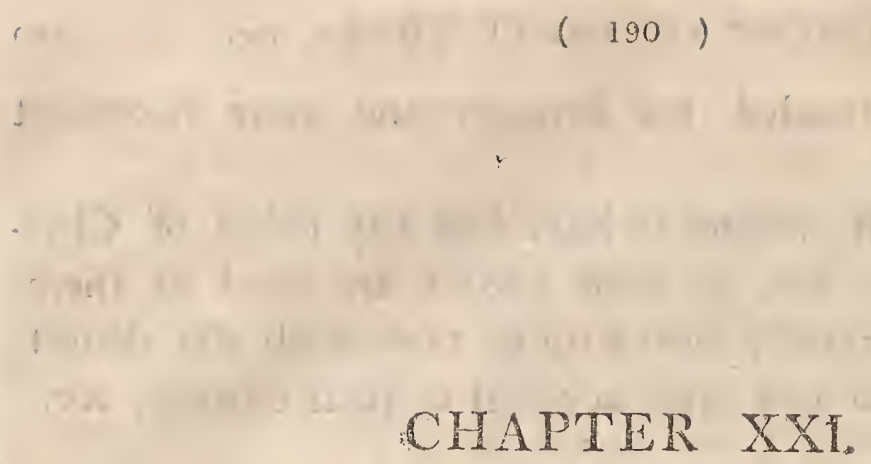

\title{
CHAPTER XXI.
}

\author{
OF WALNUTS.
}

Different Sorts defcribed-Their Propagation, Planting, and Trimming-Great Utility of the Timber-Method of keeping Walnuts in Winter.

THE Walnut, Juglans, is a native of Perfia; and the time of its introduction here is not known with certainty. It belongs to the twenty-firft clafs of Linnæus's Syftem, Monœcia Polyandria.

Thofe commonly cultivated in this country are the following varieties of the common Walnut, viz. the Double Walnut, the Large Walnut, the French Walnut, the ThinAkinned Walnut, and the Late Walnut. The Hickery Nut from North America, the fruit of which is fmall but wellflavoured, is alfo raifed here, as is the Black Virginia Walnut; but this latter is cultivated chiefly for its timber. There are feveral other forts from North America, which are planted for variety. 
The bef way of raifing thefe trees is from the Nut, which thould be gathered when full ripe: thofe with thin mells are to be preferred for this purpofe. Walnuts, unlefs a harp froff fets in, which is very feldom the cafe before they are ripe, thould be fuffered to remain on the trees till they begin: to drop of themfelves: thaking of the tree will then bring: them down. Beating them down with poles, as is ufually done, injures the trees very much, by breaking the young thoots: befide, the Nuts never keep well when they are thrathed down too early.

The Nuts may be fown in drills in the fame manner as Chefnuts: the beft time for doing this, if the feafon be dry, is Autumn; and the $\mathbb{N}$ uts munt be thoroughly dry, otherwife they will be apt to rot before they vegetate. If the Autumn be wet, they may be fown in the month of February or the beginning of March, and ought to be covered over as directed for Chefnuts, ta preferve them from mice. If they thrive well, they will be fit for tranfplanting the firf Autumn. after fowing; but, if not, they thould be fuffered to remain. another year. Bed them out in the fame manner as directed. for Chefnuts, tranfplanting every fecond or third year, until they are planted out for good. This will caufe them to throw: out fine horizontal roots, and bring them into a bearing ftate much fooner than when they make deep tap-roots. Train. them up with fine fingle ftems to about feven feet high, before you fuffer them to form heads; the branches will then be out of the reach of cattle. The time of tranfplanting them out depends: on the progrefs that they have made in the nurfery; they thould be fuffered to continue there until they have grown to a tolerable fize, and to the height juft mentioned as proper for ftandards. The ground, where they are to be

planted 
planted, fhould be well ploughed or trench $\mathrm{d}$, and the trees planted, at firt, in rows fix feet apart, and the fame diftance from tree to tree in the rows, in the quincunx order, and thus to remain till they come into bearing. This will be neceffary, as there is no dependance on the fort of fruit that trees raifed from feed may produce. After you have made choice of thofe which bear the beft fruit, the other may be planted out for timber, or cut down for itakes, or any other purpofe. The trees left for bearing mut be thinned, by taking out every other tree in the remaining rows, as they increafe in fize, till they ftand at the diftance proper for full-grown trees; which may be from twenty-four to forty-eight feet according to the richnefs of the foil and the progrefs which the trees make.

In trimming the ftems of Walnut-trees, cut off the fhoots and fmall branches clofe to the bole; and in lopping, cutting out crofs branches, or fuch as are damaged by winds and other accidents, always cut at a fork or eye, otherwife part of the branch will die and injure the tree. But, whether only a part or the whole of a branch be cut off, the Compofition ought immediately to be applied.

Formerly, Walnut-tree was much ufed for building, and for houfehold furniture; but Mahogany and other foreign timbers, have now in a great meafure fuperfeded it, efpecially in the latter article. This timber will do very well for uprights, but is rather too brittle for joifts, rafters, \&c. and, when properly polithed, it looks very well in chairs, tables, bureaus, \&ic. It is, at prefent, a good deal ufed for gun-ftocks. Walnuts thrive beft in a deep rich foil, but will do very well in a chalky foil, as may be teen on the hills in Surry, in the neighbourhood of Leatherhead, Godntone, and Carthalton; and, at Beddington-Park, the feat of the antient family of the

Carews, 
Carews, there are many fine old Walnut-trees. Thefe trees are well worth cultivating; as the yearly value of the fruit that they bear is very confiderable*. There is a great deal of money made, in plentiful years, by thinning of the nuts for pickling, both for home confumption, and alfo for exportation. The leaves of Walnuts fteeped in boiling water, and that infufion mixed with lime-water, foap-fuds, and urine, is found very efficacious for deftroying nugs and worms in the ground, and infects on trees.

Walnuts for keeping thould be fuffered to drop of themfelves, and afterwards laid in an open airy place till they are thoroughly dried; then pack them in jars, boxes, or cafks, with fine clean fand, that has been well dried in the fun, in an oven, or before the fire, in layers of fand and walnuts alternately; fet them in a dry place, but not where it is too hot. In this manner I have kept them good till the latter end of April. Before you fend them to table, wipe the fand clean off; and, if you find that they have become thrivelled, fteep them in milk and water for fix or eight hou rs before they are ufed; this will make them plump and fine, and caufe them to peel eafily.

* At Beddington, about so Walnut trees (and not above half of that number full bearers) have been let at 301.401 . and 501 . according to the crop; and it is fuppofed, that in a good feafon the renter clears 501 by the bargain.

Beddington was noted in Queen Elizabeth's time for the fineft Orangery in England. 
$(194)$

\section{CHAPTER XXII.}

OF GRAFTING AND BUDDING.

Four different ITays of Grafting, with Obfervations-On ufing the Compofition, injieud of Grraftmg-clay-Of Budding, with Olfervations, $8 \mathrm{c}$.

GrAFTING is the taking of a thoot from one tree, and inferting it into another, in fuch a manner as that both may unite clofely and become one tree; this is called, by the antient writers in hubandry and gardening, incifion, to diftinguith it from inoculating, or budding, which they call. inferere oculos.

I have taken a great deal of pains to trace the practice of grafting to its origin; but without fuccefs, as no author that I have perufed gives any fatisfactory account of it; it is, however, allowed by all to be very antient.

The 
The ufe of grafting is, to propagate any curious forts of fruits fo as to be certain of the kinds; which cannot be done by any other method: for, as all the good fruits have been accidentally obtained from feeds, fo, of the feeds of thefe, when fown, many will degenerate, and produce fuch fruit as is not worth the cultivating: but when thoots are taken from fuch trees as produce good fruit, thefe will never alter from their kind, whatever be the ftock or tree on which they are. grafted.

The principle or philofophy of grafting is fomewhat obfcure; and, had not accident given the firt hint, all our knowledge of Nature would never have led us to it. The effect is ordinarily attributed to the diverfity of the pores or ducts of the graft from thofe of the ftock, which change the figure of the particles of the juices in paffing through them to. the reft of the tree.

Mr. Bradley, on occafion of fome obfervations by Agricola, fuggefts fomething new on this head. The ftock grafted on, he thinks, is only to be confidered as a fund of vegetable matter which is to be filtered through the cion; and digented, and brought to maturity, as the time of growth in the veffels of the cion directs. $\therefore$ A cion, therefore, of one kind grafted on a tree of another, may be rather faid to take root in the tree that it is grafted in, than to unite itfelf with it: for it is vifible, that the cion preferves its natural purity and intent, - though it be fed and nourifhed by a mere crab; which is, without doubt, occafioned by the difference of the veffels in the cion from thofe of the ftock; fo that grafting may be juntly compared to planting.

In profecution of this view of that ingenious author; we add, that the natural juices of the earth, by the fecretion and 
comminution in pafing through the roots, \&c. before they arrive at the cion, muft doubtlefs arrive there lalf elaborated and concoeted, and fo difpored for a more eafy, plentiful, and perfe affimilation and nutrition; whence the cion muft neceffarily grow and thrive better and fafter than if it were put immediatcly in the ground, there to live on coarfer diet and harder of digeftion; and the fruit produced by this further preparation in the cion munt be finer, and further exalted, than if fed immediately from the more imperfectly prepared and altered juices of the ftock. It may, perhaps, be thought unneceffary to fay any thing here on grafting, as it has been fo fully treated of by $\mathrm{Mr}$. Miller, and other writers on gardening; but, as this Treatife is principally on pruning and training, grafting feems naturally connected with it.

I perfuade myfelf, therefore, that a few inftructions in grafting will not be unaccetable, as they may fave the reader the trouble of turning to other books; efpecially as they are more particularly intended for the grafting of old trees, and fuch as are found, when they come to bear, to be a different fort from what was expected: for, although nurferymen in general are very careful in thefe matters, yet, through the inattention of their men, or fome miftake, or by an improper choice of the forts, it will frequently happen, that, after waiting thirteen or fourteen years, when the trees come to bcar, the fruit is found of a bad quality, and not fit for ufe: fo that new grafting or budding is abfolutely neceffary.

I thall, therefore, give what directions may be neceffary on that fubjeet, to render it plain and eafy to thofe who have not been regularly inferucted in the art of grafting from general pratice; and add a method which 1 have followed for fome years, and which I flatter myfelf will be found an improvement. 
The Thoots ufed in grafting are called cions, or grafts; and in the choice of thefe the following directions thould be carefully obferved. Ift. That they are thoots of the former year; for when thcy are older they never fucceed well. 2dly. Always to take them from healthy fruitful trees; for, if the trees from which they are taken be fickly, the grafts very often parrake fo much of the diftemper as rarely to get the better of it, at leat for fome years; and when they are taken from young luxuriant trees, whofe veffels are generally large, they will continue to produce luxuriant thoots, but are feldom fo productive as thofe which are taken from fruitful trees whofe Moots are more compact, and the joints clofer together; at leaft it will be a great number of years before the luxuriant grafts begin to produce fruit, even if managed with the greatent kill. 3dly, You thould prefer thofe grafts which are taken from the lateral or horizontal branches, to thofe from the Arong perpendicular thoots, for the reafons before given.

Thefe grafts, or cions, Mhould be cut off from the trees before their buds begin to fwell, which is generally three weeks or a month before the feafon for graftingy; therefore, when they are cut off they thould he laid in the ground with the cut downwards, burying them half their length, and covering their tops with dry litter, to prevent their drying; if a fmall joint of the former year's wood be cut off with the cion, it will preferve it the better, and when they are grafted this may be cut off; for at the fame time the cions muft be cut to a proper length before they are inferted in the ftocks; but, till then, the thoots fhould remain of their full length, as they were taken from the tree, which will better preferve them frc $m$ thrinking; if thefe cions are to be carried to a confiderable diftance, it will be proper to put their ends into a 
lump of clay, and to wrap them up in mofs, which will preferve them freth for a month, or longer; but thefe thould be cut off from the trees earlier than thofe which are to be grafted near the place where the trees are growing.

Having given directions for the cions and grafts, we next come to that of the ftock, which is a term applied to the trees intended for grafting; thefe are, either fuch old trees as are already growing in the places where they are to remain, whofe fruit is intended to be changed; or young trees, which have been raifed in the nurfery for a fupply to the garden: in the former cafe, there is no other choice, than that of the branches, which fhould be fuch as are young, healthy, well fituated, and have a fmooth bark; if thefe trees are growing againft walls, or efpaliers, it will be proper to graft fix, eight, or ten branches, according to the fize of the trees, by which they will be much fooner furnifhed with branches again, than when a lefs number of cions are put in; but in ftandard trees, four, or at molt fix, cions will be fufficient.

In the choice of young ftocks for grafting, you fhould always prefer fuch os have been raifed from the feed, and that have been once or twice tranfplanted.

Next to thefe, are thofe ftocks which have been raifed from cuttings, or layers; but thofe which are fuckers from the roots of other trees thould always be rejected; for thefe are never fo well rooted as the others, and conftantly put out a great number of fuckers from their roots, whereby the borders and walks of the garden will be always peftered during the Summer feafon; thefe are not only unfightly, but they alfo take off part of the nourithment from the trees.

If thefe ftocks have been allowed a proper diftance in the nurfery where they have grown, the wood will be better ripened, 
ripened, and more compact, than thofe which have grown clofe, and have been there drawn up to a greater height; the wood of thefe will be foft, and their veffels large; fo that the cions grafted into them will thoot very ftrong; but they will be lefs difpofed to produce fruit than the other: and when trees acquire an ill habit at firtt it will be very difficult to reclaim them afterward.

Having directed the choice of cions and itocks, we come next to the operation; in order to which you mult be provided with the following tools:

I. A neat fmall hand-faw, for cutting off the heads of large ftocks.

2. A good ftrong knife, with a thick back, to make clefts in the ftocks.

3. A Tharp pen-knife, or budding-knife, to cut the grafts.

4. A grafting chifel and a fmall mallet.

5. Bafs ftrings, or woollen yarn, to tie the grafts with; and fuch other inftruments and materials as you thould find neceffary, according to the fort of grafting which you are to perform.

6 A quantity of clay, which thould be prepared a month before it is uled, and kept turned and mixed, like mortar, every other day: this is to be made in the following manner.

Get a quantity of ftrong fat loam (in proportion to the quantity. of trees intended to be grafted); then take fome new ftone-horfe dung, and break it in among the loam; and if you cut a little ftraw, or hay, very fmall, and mix amongit it, the loam will hold together the better; and if there be a quantity of falt added, it will prevent the clay from dividing in dry weather; thefe muft be well firred together, putting water to them after the manner of making mortar; it thould 
be hollowed like a difh, filled with water, and kept every other day ftirred; but it ought to be remembered, that it thould not be expofed to the froft, or drying winds; and the oftener it is ftirred and wrought the better.

Of late years, fome perfons have made ufe of another Compofition for grafting, which they have found to anfwer the intention of keeping out the air better than the clay before defcribed. This is compofed of turpentine, bees-wax, and rofin, melted together; which, when of a proper confiftence, may be put on the ftock round the graft, in the fame manner as the clay is ufually applied; and, though it be not above a quarter of an inch thick, it will keep out the air more effectually than the clay; and, as cold will harden this, there is no danger of its being hurt by froft, which is very apt to caufe the clay to cleave, and fometimes to fall off; and, when the heat of the Summer comes on, this mixture will melt, and fall off without any trouble. In the ufing of this, there fhould be a tin or copper pot, with conveniency under it to keep a very gentle fire with fmall coal; otherwife the cold will foon condenfe the mixture: but you mult be careful not to apply it too hot, left you injure the graft. A perfon who is a little accuftomed to this Compofition will apply it very faft; and it is much eafier for him to work with than clay, efpecially if the feafon thould prove cold.

There are feveral ways of grafting, but four principal ones; [See Plate XI.]

1. Grafting in the rind, called alfo houlder-grafting; which is only proper for large trees: this is called crowngrafting, becaufe the grafts are fet in form of a circle, or crown; and it is generally performed about the latter end of March, or the beginning of April.

2. Clefto 
2. Cleft-grafting, which is alfo called ftock, or nit-grafting; this is proper for trees or ftocks of a leffer fize, from an inch to two inches, or more, diameter : this grafting is to be performed in the months of February and March, and fupplies the failure of the efcutcheon way, which is practifed in June, July, and Augurt.

3. Whip-grafting, which is alfo called tongue-grafting: this is proper for fmall ttocks of an inch, half an inch, or lefs, diameter; it is the moft effectual way of any, and is moft in ufe.

4. Grafting by approach, or ablactation: this is practifed when the ftock that you would graft on, and the tree from which you take your graft, ftand fo near together, that they may be joined; and thould be performed in the month of April. This method, which is alfo called inarching, is chiefly ufed for Jafmines, Oranges, and other tender exotic trees.

We come next to the manner of performing the feveral methods of grafting.

The firt, which is termed rind, or thoulder-grafting, is feldom practifed but on large trees, where either the head or the large branches are cut off horizontally, and two or more cions put in, according to the fize of the branch, or ftem; in doing this, the cions are cut flat on one fide, with a fhoulder to reft upon the crown of the ftock; then the rind of the ftock munt be raifed up, to admit the cion between the wood and the bark of the ftock, which muft be inferted about two inches, fo as that the fhoulder of the cion may meet, and clofely join the crown of the ftock; and, after the number of cions is inferted, the whole crown of the ftock hould be well clayed over, leaving two eyes of the cions uncovered therewith, which will be fufficient for thooting. This method of grafting was much more in practice formerly than it is at prefent; and 
the difcontinuance of it was caufed by the ill fuccefs with which it was attended; for, as thefe cions were placed between the rind of the ftock and the wood, they were frequently blown out by ftrong winds, after they had made large thoots, which has fometimes happened after five or fix years' growth; fo that, whenever this method is practifed, there thould be fome ftakes faftened to fupport the cions until they have almort covered the ftock.

The next method is termed cleft, or ftock-grafting; this is practifed upon ftocks, or trees, of a fmaller fize, and may be ufed with fuccefs where the rind of the ftock is not too thick, whereby the inner bark of the cion will be prevented from joining to that of the ftock. This may be performed on Ptocks, or branches, that are more than one inch diameter: the head of the ftock, or branch, muft be cut off with a llope, and a lit made the contrary way, in the top of the llope, deep enough to receive the cion, which thould be cut floping like a wedge, fo as to fit the flit made in the ftock; being careful to leave that fide of the wedge which is to be placed outward much thicker than the other: and in putting the cion into the flit of the ftock, there muft be great care taken to join the rind of the cion to that of the ftock; for if thefe do not unite, the grafts will not fucceed; when this method of grafting is ufed to ftocks that are not ftrong, it will be proper to make a ligature of bafs, to prevent the lit of the ftock from opening; then the whole thould be clayed over, to prevent the air from penetrating the flit, fo as to deftroy the grafts, only leaving two eyes of the cions above the clay for hooting.

The third method is termed whip, or tongue-grafting, which is the moft commonly practifed of any by the nurfery- 
men near London, efpecially for fmall ftocks, becaufe the cions much fooner cover the ltocks in this method than in any other.

This is performed by cutting off the head of the ftocks floping; then there muft be a notch made in the flope toward the upper part downward, a little more than half an inch deep, to receive the cion, which mut be cut with a flope upward, and a nit made in this nlope like a tongue, which tongue muft be inferted into the flit made in the flope of the ftock, and the cion muft be placed on one fide of the ftock, fo as that the two rinds of both cion and ftock may be equal and join together exactly; then there thould be a ligature of bafs to faften the cion, fo as that it may not be eafily difplaced, and afterwards clay it over as in the former methods.

The fourth fort of grafting is termed, inarching, grafting by approach, or ablactation. This is only to be performed when the ftocks that are defigned to be grafted, and the tree from which the graft is to be taken, ftand fo near together, as that their branches may be united. It is commonly practifed on tender exotic plants, and fome other forts which do not fucceed in any of the other methods.

In performing this operation, a part of the ftock, or branch, muft be lit off about two inches in length, obferving always to make choice of a fmooth part of the ftock; then a finall notch thould be made in this flit of the itock downward, in the fame manner as hath been direeted for whip-grafting; the branch of the tree defigned to be inarched hould have a part Nit off in like manner as the ftock, and a lit made upward in this fo as to leave a tongue, which tongue thould be inferted into the lit of the ftock; obferving to join their rinds equally, that they may unite well together; then make a ligature 
of bafs, to keep them exactly in their fituation, and afterwards clay this part of the ftock over well, to keep. out the air; in this method of grafting, the cion is not feparated from the tree until it is firmly united with the ftock, nor is the head of the ftock, or branch, which is grafted, cut ofi till this time, and only half the wood pared off with a flope, about three inches in length, and the fame of the cion; or graft.

This method of grafting is not performed fo early in the feafon as the others; it being done in the month of April, when the fap is flowing, at which time the cion and ftock will join together, and unite much fooner than at any other feafon.

The Walnut, Fig, and Mulberry, will take by this method of grafting, but neither of thefe will fucceed in any of the other methods; there are alfo feveral forts of evergreens that may be propagated by this method of grafting; but all the trees that are grafted in this way are weaker, and never grow to the fize of thofe which are grafted in the other methods; therefore this is rarely practifed, but on fuch forts of trees as will not take by the other methods.

\section{Obfervations on Grafting.}

In a long continuance of dry weather the grafts very frequently fail of taking; fometimes, no doubt, owing to the improper choice of the grafts, as well as to the dry weather. Great care thould always be taken not to graft with weak Thoots, particularly thofe taken. from near the top. Always take your grafts from the lower end of the fhoots, and obferve that the wood is plump and frefh; for fuch as are 
Thriveled feldom or never take. Where any have miffed in the fpring, I would advife to cut off, about the middle or latter end of June, fome fine healthy grafts of the fort that you wilh to graft with, open the bark in the fame manner as you do for budding (of which hereafter), and infert the graft with a piece of the former year's wood on it: after you have done this, rub in, with a brufh, fome of the Compofition in

liquid ftate; then wrap your bafs round it, as is done for Spring grafting, leaving about three eyes on the fhoot, which fhould be tied on with the bafs as tight as you can; then cover the outfide of the bafs, thus tied up, with the Compofition to the thicknefs of about one eighth of an inch, obferving alfo to cover the end of the moot with the fame, to exclude the air and wet. In about three weeks, or a month, look over the grafts to fee if they have taken. When the graft begins to fwell, it will throw off the Compofition: when that is the cafe, always remember to apply more, to prevent the air from penetrating the incifion.

In the month of September, you thould examine whether the wounds are all healed up, and the two barks perfectly united; if they are, you may lacken the bafs; and if they are perfectly healed up, it may be taken off: but if not, the bafs muft again be tied on, and covered with the Compofition as before directed; letting it remain till the following Spring. You may then take the bafs off; and, if you find that the two barks have feparated during the Winter, with the point of a Sharp knife, cut out all the brown part of the bark (which, if left, would infallibly bring on the canker), and rub the Compofition into the wound. If your grafts have produced ftrong leading fhoots, the tops of them fhould be pinched off with the finger and thumb; but if they have not fhot frong; 
they fhould not be cut till the Spring, when they thould be cut to three or four eyes, according to their ftrength, to make them produce horizontal thoots, and form handfome heads. This grafting thould always be performed in moift or cloudy weather.

I have already, in the Chapter on Apple-trees, mentioned. the advantages to be derived from ufing the Compofition inftead of grafting-clay, and alfo given fome directions for the fame. Rubbing a little of it into the incifion will effectually $p$ event the canker, and in applying it round the graft a much lefs quantity will be fufficient than of the clay; as it need not be more than three inches round in grafting fmall ftems or thoots, and fo in proportion for thofe which are larger. The Compofition will keep the cion moint, and will not crack and fall off in dry weather as clay does. The Compofition to be ufed in grafting thould be of fuch a confiftence as to work eafily with the hand, or a knife, or fmall trowel, rather fofter than grafting-clay generally is. Any perfon, who gives this method a fair trial, will find it to be a fure, neat, and expeditious way of grafting.

Grafting, or budding, fhould be performed as near to the upper fide of a bud as poffible. The moft proper place for inferting the cion, or bud, is at the joint a little above the crofs thoot.

\section{Inoculation, or Budding.}

This is commonly practifed upon all forts of ftone-fruit in particular; fuch as Peaches, Nectarines, Cherries, Plums, \&c. as alfo Oranges and Jafmines; and is preferable to any fort of grafting for moft kinds of fruit. The method of performing it is as follows: you muft be provided with a fharp 
peri-knife, or what is commonly called a budding-knife, having a flat haft (the ufe of which is, to raife the bark of the ftock to admit the bud), and fome found bafs mat, which Ihould be foaked in water to increafe its ftrength, and make it more pliable; then, having taken off cuttings from the trees that you would propagate, you thould choofe a fmooth part of the ftock, about five or fix inches above the furface of the ground, if defigned for dwarfs, and for half-ftandards at three feet; but, for ftandards, they hould be budded fix or more feet above the ground; then with your knife make an horizontal cut acrofs the rind of the ftock, and from the middle of that cut make a nit downwards about two inches in length; fo that it may be in the form of a $T$ : but you muft be careful not to cut too deep, left you wound the ftock: then, having cut off the leaf from the bud, leaving the footftalk remaining, you thould make a crofs cut about half an inch below the eye, and with your knife llit off the bud with part of the wood to it, in form of an efcutcheon: this done, you muft with your knife pull off that part of the wood which was taken with the bud, obferving whether the eye of the bud be left to it or not (for all thofe buds which lofe their eyes in fripping Thould be thrown away, being good for nothing); then having gently raifed the bark of the fock where the crols incifion was made, with the flat haft or handle of your knife clear of the wood, you thould thruft the bud therein, obferving to place it fmooth between the rind and the wood of the ftock, cutting off any part of the rind belonging to the bud which may be too long for the flit made in the ftock; and, having thus exaelly fitted the bud to the ftock, you muft tie them clofely round with bafs mat, beginning at the under part of the Ait, and fo proceed to the top; taking care that 
you do not bind round the eye of the bud, which fhould be left open.

When your buds have been inoculated three weeks or a month, you will fee which of them have taken; thofe which appear hriveled and black are dead; but thofe which remain frefh and plump, you may be fure are joined; and at this time you fhould loofen the bandage, which, if not done in time, will pinch the ftock, and greatly injure, if not deftroy, the bud.

In the March following you muft cut off the ftock about three inches above the bud; floping it, that the wet may pafs off, and not enter the flock: to this part of the ftock left above the bud, it is very proper to fatten the fhoot which proceeds from the bud, and which would be in danger of being blown out, if not prevented; but this muft continue no longer than one year, after which it muft be cut off clofe above the bud, that the ftock may be covered thereby.

The time for inoculating is, from the middle of June until the middle of Auguft, according to the forwardnefs of the feafon, and the particular forts of trees to be propagated; but the time may be eafily known, by trying the buds, whether they will come off well from the wood, or not. However, the moft general rule is, when you obferve the buds formed at the extremity of the fame year's moots, which is a fign of their having finithed their Spring growth.

The firft fort commonly inoculated is the Apricot, and the latt the Orange-tree, which thould never be done until the middle of Auguft; and in doing of this work, you thould always make choice of cloudy weather; for if it be done in the middle of the day, in very hot weather, the fhoots will perfpire fo fant as to leave the buds deftitute of moifture; nor 
Thould you take off the cuttings from the trees long before they are ufed; but if you are obliged to fetch your cuttings from fome diftance, as it often happens, cut off the leaves, but let all the footftalks remain, then wrap the cuttings up in wet mols and put them in a tin box (carrying them in a tin cafe with water being now difufed) to exclude the air; in this manner you may carry them to any reafonable diftance in good condition for inoculating.

It is a very improper practice of many perfons, to throw their cuttings into water; for this fo faturates the buds with moifture, that they have no attractive force left to imbibe the fap of the ftock; for want of which they very often mifcarry.

But before I quit this fubject, I beg leave to obferve, that, though it is the ordinary practice to divent the bud of that part of the wood which was taken from the fhoot with it; yet, in many forts of tender trees, it is beft to preferve a little wood to the bud, without which they often fail. The not obferving this has occafioned fome people to imagine, that certain forts of trees are not to be propagated by inoculation; whereas, if they had performed it in this method, they might have fucceeded, as I have feveral times experienced.

The next thing neceffary to be known by thofe who would practife this art is, what trees will take and thrive, by being grafted, or inoculated, upon each other; and here there have been no fure directions given by any of the writers on this fubject; for there will be found great miftakes in all their books, in relation to the matter; but, as it would extend this article too far, if all the forts of trees were to be here enumerated which will take upon each other by grafting or budding, I thall only give fuch general directions as, if attended 
to, will be fufficient fo to inftuct perfons, as that they may fucceed.

All fuch trees as are of the fame genus, i.e. which agree in their flower and fruit, will take upon each other: for inftance, all the Nut-bearing trees may be fafely grafted on each other, as may all the Plum-bearing trees, under which head I reckon not only the feveral forts of Plums, but alfo the Almond, Peach, Nectarine, Apricot, \&c. which agree exactly in their general characters, by which they are diftinguithed from all other trees; but, as many of thefe are very fubject to emit large quantities of gum from the parts of the trees which are deeply cut and wounded; in the tender trees of this kind, viz. Peaches and Neetarines, which are molt fubjeet tothis, it is found to be the fureft method to bud or inoculate: thefe forts of fruits.

All fuch trees as bear cones will do well upon each other, though they may differ in one being ever-green, and the other rhedding its leaves in Winter; as is obfervable in the Cedar of Libanus, and the Larch-tree, which are found to fucceed upon each other very well; but thefe muft be grafted by approach; for they abound with a great quantity of refin which is apt to evaporate from the graft if feparated from the tree before it is joined with the ftock, whereby they are often deftroyed; as alfo the Laurel on the Cherry, or the Cherry on the Laurel. All the maft-bearing trees will alfo take upon. each other, and thofe which have a tender foft wood will do well if grafted in the common way; but thofe that are of a more firm contexture, and are flow growers, thould be grafted by approach.

By ftrictly obferving this rule, we fhall feldom mifcarry; provided the operation be rightly performed, and at a proper feafon, 
feafon, unlefs the weather fhould prove very bad, as it fometimes happens, whereby whole quarters of fruit-trees mifcarry; and it is by this method that many kinds of exotic trees are not only propagated, but alfo rendered hardy enough to endure the cold of our climate in the open air; for, being grafted upon ftocks of the fame fort which are hardy, the grafts are rendered more capable of enduring the cold, as hath been experienced by moft of our valuable fruits now in England, which were formerly tranfplanted hither from more foutherly climates, and were at firft too impatient of our cold to fucceed well abroad; but have been, by budding or grafting upon more hardy trees, rendered capable of refifting our fevereft cold.

Thefe different graftings feem to have been greatly in ufe among the Antients, though they were certainly mitaken in the feveral forts of fruits which they mention as having fucceeded upon each other; as the Fig upon the Mulberry, the Plum upon the Chefnut, with many others of the like kind; moft of which have been tried by Mr. Miller, and found not to fucceed; therefore what has been advanced on this head by the Antients is not founded on experience; or, at leaft, they did not mean the fame plants which at prefent are called by thofe names; though I cannot help thinking that we are apt to pay too much deference to the writings of the Antients, in fuppofing them feldom to be miftaken, or to affert a falfehood; whereas, if their works are carefully examined, it will be found, that they have often copied from each other's writings without making experiments to prove the truth of their affertions; and it is well known; that the ranging of plants before Cæfalpinus's time (which is about 200 years fince) was, by their outward appearance; or from EE 2

the 
the fuppofed virtues of them, a method that is now juftly exploded; and it has been obferved, from many repeated trials, that, however plants may refemble each other in the Thape and make of their leaves, manner of thooting, \&c. unlefs. they agree in their fruit, and their other diftinctive characters, they will not grow upon each other, though performed with ever fo much art.

\section{Objervations on Budding: Pear-Trees on Walls:}

When the Pear-trees which are grafted in the Spring have: not taken, I would advife to cut them off, a little below the graft, at a joint or bud. The tree will then throw out a. great number of healthy thoots: rub thefe all off; except fo many as will be fufficient to fill the wall; nailing thofe up, to prevent the wind from breaking them.

About the latter end of July the Thoots will be fit to bud, which thould be done about that time. I would recommend leaving a little of the wood on the infide of the bud when inferted into the ftock, rubbing in the Compofition, and tying on the bafs as before.

Laft Spring I grafted fome Summer Bonchrêtiens with the Bergamot de Pafque (or Eafter Bergamot), and Pear d'Auch, moft of which failed. I then cut them off below the grafts, and in July following they had produced thoots from five to fix feet long, which I budded in the latter end of that month. with the beforementioned forts, which all took. About the: beginning of September I ordered a man to lacken the baffes; which having left too loofe, the barks began to feparate. I then made him tighten them, letting them remain till the 
following Spring. About the beginning of April, when I faw the buds begin to fhoot, I cut the fhoots near to the buds, but finding many where the bark had not united, and fome of the eyes apparently dead, I took a tharp pen-knife and cut out all the decayed bark, rubbing in the Comporition, in the liquid ftate, till the hollow parts were filled up; I then fmoothed it off, with the finger, even with the bark of the ftock. I alfo rubbed fome of the Compofition over thofe eyes that were in the worft ftate, being quite black; but with very little hope of recovery. To my great aftonimment, many of thofe which feemed perfectly dead, recovered, and by the middle of July had thoots from five to fix feet long (many. of the thoots which took well have fruit buds formed for next year), and covered a fpace of wall larger than a young tree would have done in eight years; all the cavities where I cut out the dead bark, and applied the Compofition, were, in the courfe of the Summer, filled up with found wood, and the bark between the ftocks and grafts perfectly united.

Three years ago I budded on fome Brown Beurrés and Crafanes with Pear d'Auch, one of which now covers a wall fixteen feet high, and fifteen feet long, and has more fruit on it this year than a maiden tree would have produced twenty years after planting.

I never recommend budding or grafting of old trees, except when you have bad forts, or more of any fort than you want for a fupply: in that cafe, I would recommend to bud or graft with Pear d'Auch, Colmars, and Winter Bonchrêtiens, which keep much longer than Beurrés, Crafanes, \&c.

It will be neceffary to give fome directions for ftandards that have been grafted in the Spring, and have miffed. In fuch cafe, they fhould be cut below the graft, as directed for wall. 
trees; and when fo treated, they will throw out a great number of thoots, which thould by no means be too foon thinned, as in that cafe they will be liable to be broken by the wind. You may begin to take off the weakeft thoots about the latter end of May, or beginning of June. About the middle of the latter month, they will have acquired confiderable ftrength; you may then thin them; leaving as many ftrong regular thoots, and of thofe neareft the top of the ftem, as will form a handfome head. If the ftem be very ftrong, it will be neceffary, perhaps, to leave more than you intend to bud, on purpofe to receive the fap, which will flow in great abundance from a large trunk, and, without this precaution, would be apt to burft the hoots, if there be not a fufficient number to receive it. I have often feen fhoots as large as my arm burft by a fuperabundance of fap. When that is likely to happen, the beft thing you can do is, to fcarify the thoots, and rub a little of the Compofition into the wound. 
(215)

\title{
CHAPTER XXII.
}

\author{
OF A GARDEN.
}

Its. Situation, Size, Soil, and Form-Of Watering, Draining, \&c. Of the Melon-ground.

A GARDEN, if poffible, thould be on a gentle declivity: towards the South, a little inclining to the Eaft to receive the benefit of the morning fun. If it be fituated in a bottom, the wind will have the lefs effeet upon it; but then damps and fogs will be very prejudicial to the fruit and other crops: and if fituated too high, although it will in a great meafure be free from damps and fogs, it will be expofed to the fury of the winds, to the great hurt of the trees, by breaking their branches and blowing down the bloffoms and fruit. A garden Thould be well theltered from the North and Eaft, to prevent the blighting winds from affecting the trees; and alfo from. the Wefterly winds, which are very hurtful to gardens in the Spring or Summer months. If a garden be not naturally. theltered with gentle rifing hills, which are the beft thelter of any, 
any, plantations of foreft-trees made at proper diftances, fo as not to thade it, will be found the beft fubfitute. At the fame time, there ought to be a free admittance for the fun and air. On that account, a place furrounded by woods is a very improper fituation for a garden or orchard, as a foul ftagnant air is very unfavourable to vegetation; and it is alfo obferved, that blights are much more frequent in fuch fituations, than in thofe that are more open and expofed.

I have recommended the practice of intermixing fruit-trees in Thrubberies and plantations of this kind to feveral gentlemen, who have adopted it with fuccefs. While the fruittrees are in flower, they are a great ornament to the thrubberies; and in Summer and Autumn the different colours of the fruit have a beautiful appearance. Add to this the advantage of a plentiful fupply of fruit for the table, and for making Cider and Perry; and if fome Cherries are interfperfed among them, they will be food for birds, and be the means of preventing them from deftroying your finer fruit in the orchard or garden.

About fix years ago, my worthy friend Walter Urquhart, efq. of Warley Park, near Waltham Abbey, planted a clump of fruit and foreft trees, with flowering hrubs in front, next the houfe, to fcreen his garden, which was fo injudiciounly fituated as to prefent the walls to view from the houfe, and from almont every part of his beautiful park. The fruit-trees made choice of for this purpofe were large ones of various kinds, which had been headed down, and were then full of fruitbuds. Thefe trees were planted at a proper diftance from the garden, fo as not to thade the walls, and the foreft-trees interfperfed among them, according to the height that they would attain when full grown. 
Mr. Urquhart has continued to take up fome of the forefttrees from time to time, as the fruit-trees fpread their branches and require more room. Thus, the clump has become a nurfery for foreft-trees; a great deal of money is faved which would otherwife have been expended in the purchafe and carriage of plants; and from it he has made fome very fine new plantations. The fruit-trees make a handfome orchard, and at the fame time cover the walls of the garden.

When the fituation will not admit of fuch plantations, I would advife planting fome crofs rows of fruit-trees in the garden, at the diftance of forty or feventy yards from each other, more or lefs according to the fize of the garden. In long rows, one row of trees will be fufficient on each fide of the walk; but in the fhorter crofs rows, there fhould be two rows on each fide. The trees thould not be planted oppofite to each other, but alternately; fo as that thofe of one row may be oppofite to the open fpaces of the other. Trees planted in this manner will have a good effect, and will alfo ferve to break the force of high winds, and prevent a great deal of damage which might otherwife be done to the reft of the trees throughout the garden. Thofe which I would recommend for the above purpofe are dwarfs, with ftems about two feet high, which can eafily be obtained by cutting off the lower branches.

In laying out a new garden, another very effential point is, to make choice of a good foil. It hould be two or three feet deep; but if deeper the better; of a mellow pliable nature, and of a moderately dry quality; and if the ground thould have an uneven furface, I would by no means attempt to level it; for by that unevennefs, and any little difference there F F may 
may be in the quality, you will have a greater variety of foil adapted to different crops. The beft foil for a garden is, a rich mellow loam; and the worf, a fliff heavy clay. A light fand is alfo a very unfit foil for a garden.

Sea-coal anhes, or the cleaning of ftreets and ditches, will be found very proper to mix with a ftrong foil; and if the ground fhould be cold, a large quantity of coal athes, fea fand, or rotten vegetables, thould be laid upon it, in order to meliorate and loofen the foil, and render it eafy to work.

Lime rubbirh, or light fandy earth from fields and commons, will alfo be found of great fervice to fiff clayey ground.

If the foil be light and warm, rotten neat's dung is the beft drefling that you can give it. If horfe-dung be ever ufed, it muft be completely rotted, otherwife it will burn up the crop the firft hot weather.

With regard to the form of a garden, there are various opinions, and it fometimes depends on the fituation; but where you are at perfect liberty I would prefer a fquare or oblong. As to the fize, it may be from one acre to fix or eight within the wall, according to the demand for vegetables in the family. It thould be walled round with a brick wall from ten to twelve feet high: but, if there be plenty of walling, which there may be when you are not ftinted with refpect to ground, I would prefer walls ten feet high, to thofe that are higher, and I am convinced they will be found more convenient. The garden fhould be furrounded with a border, or flip, from forty to fixty feet wide or more, if the ground can be fpared; and this again inclofed with an oak paling from fix to eight feet high, with a cheval-de- 
frife * at top, to prevent people's getting over : it will alfo ftrengthen the paling.

By making flips on the outfide of the garden wall, you will have plenty of ground for Goofeberries, Currants, Strawberries, \&x. You may allot that part of the flips which lies neareft to the ftables (if well heltered, and expofed to the fun,) for Melor and Cucumber beds; and you can plant both fides of the garden-wall, which will give a great addition to the quantity of wall fruit.

If the foil of the new garden be ftrong, it fhould be plowed or dug three or four times before you plant any thing in it; and if it be thrown up in ridges during the Winter, it will be of great fervice, as the froft will meliorate and loofen its parts.

Gardens, if poffible, thould lie near a river, or brook, that they may be well fupplied with water. From thefe, if the garden does not lie too high, the water may be conducted to it by drains, or, which is much better, by pipes, taking care to lay them low enough to receive the water in the drient feafon, which is the time when it will be moft wanted.

If there be no running water near the garden, and if the latter lies on a declivity near a public road, I would advife

* A very good cheval-de-frife may be conftructed as follows : take a piece of wood of a convenient length, about four inches broad, and one inch and a quarter thick, and plane the upper edge into the thape of the roof of a houfe of a low pitch; then draw a line on each fide from end to end, about an inch and a quarter below the upper edge, and through thefe lines drive twelve-penny nails about four inches diftant from each other, fo as to come out near the upper edge on the oppofite fide. Each nail fhould be oppofite the middle of the fpace between two nails on the other fide. The nail heads fhould be funk in the wood, and fmall ftrips nailed over them: then drive in tenter-hooks between the nail points, and nail the whole firmly on the outfide of the top of the paling. In this manner procced till you have finifhed the whole of the fence. 
to make a hollow drain, or a cut, from the moft convenient part of the road to receive the water that wafhes the road in rainy weather, and convey it to a large ciftern, or tank, in the upper part of the garden; this, if the road be mended with lime-ftone or chalk, will prove an excellent manure. The water from the ciftern, or from the river, may be conducted to the different quarters by means of pipes, which having cocks at proper places, the water may be turned upon the different quarters of the garden at pleafure. Or the water may be conveyed in proper channels, and turned on the quarters in the fame manner as in watering meadows.

Thefe pipes, channels, \&c. will be a confiderable expence at firft; but they will foon repay it by faving a great deal of time, which would otherwife be fpent in pumping and carrying water. The moft convenient time for turning the water on, is, in general, during the night; and in dry weather it would then be of the moft effential fervice.

If the fituation be fuch that you are obliged to pump the water from deep wells, there thould be a large refervoir, in which it fhould be expofed to the fun and air for fome days before it is ufed: it may then be turned on as above.

If the ground be wet and fpewy, it will be proper to make a bafin in the moft convenient place, to receive the water that comes from the drains, and to collect the rain that falls on the walks.

In laying out the quarters, you muft be guided in great meafure by the form and fize of the garden; but do not lay them out too fmall, as in that cafe a great part of the ground will be taken up with walks. The beft figure is a fquare or oblong, when the garden is of that form; but if not, they 
may be laid out in any other figure that is thought to be mont convenient.

The middle walks thould be about feven feet, which is wide enough to admit a cart; and the others about three or four feet broad; with a border on each fide, five or fix feet wide, at leaft, between the walk and the fruit-trees. Walks in kitchen-gardens are generally gravclled, and but feldom laid with turf, as the frequent wheeling and treading foon deftroys the grafs and renders them very unfightly: but a binding fand makes good walks and they are eafily kept; for when mofs or weeds begin to grow, they may be cleaned with a horfe-hoe, or fcuffeled over with a Dutch-hoe, in dry weather, and raked a day or two after, by which they will be made always to look neat and clean. I, however, give the preference to fea-coal athes, which in my opinion make the beft walks for a kitchen-garden, and they are eafier kept than any other, being firm and dry, and cleaner to walk on than fand, efpecially after froft.

The bottoms of the walks thould be filled up with brick rubbifh, chippings of ftones, or gravel and ftones; thofe raked off the quarters will do very well, and by ufing them you will fave carriage.

If the foil be ftiff and wet, or fubject to detain the moifture, there muft be under-ground drains made to carry- off the water. In this cafe, let the main drain be made under the walk, to receive and carry off the water from thofe under the quarters. Draining, when the foil is wet, is abfolutely neceffary, otherwife the trees will never produce good wellflavoured fruit, and your kitchen plants will be much injured: the drains alfo under the walks will keep them dry and firm, and make them fit for carting and wheeling on in wet weather.

The 
The borders under the walls, in the infide, fhould be from ten to twenty feet wide, according to the fize of the garden, to give full liberty to the roots of the trees to fpread. There thould be a foot path about two feet and a half from the wall, for the greater convenience of nailing the trees, gathering the fruit, \&c. This walk thould be from two to two feet and a half wide (to admit a barrow, or barrow engine for watering the trees), and covered with fand, or, which is better, coalafhes*, about two or three inches thick; but without any gravel or rubbih below. On thefe borders you may have early or late crops, according to the afpect; but by no means plant any deep-rooting plants, fuch as cabbages, beans, peas, \&c. (except early frame peas), which would be very hurtful to the trees.

The reafons for allotting part of the outfide flip next the ftable for hot-beds for raifing Melons and Cucumbers, are, firft, becaufe there will be no litter to carry-in within the walls to dirty the walks; fecondly, the beds will not be feen from the garden; and laftly, the convenience of carrying the dung, by which a great deal of time will be faved in carting and wheeling.

It will be neceffary, efpecially in expofed fituations, to enclofe the Melon-ground with either a wall or paling from fix to eight feet high. It was formerly a practice to enclofe Melongrounds with reed fences; but, although they are tolerably warm, and eafily removed from one place to another (being made in feparate panels), they are very apt to harbour vermin.

* Slugs avoid coal afh walks, efpecially when new-laid and rough; fuch walks, therefore, may be of fervice, as they will, in fome degree, obftruct the paffage of flugs and fnails from one quarter to another.

Melons 
Melons are beft worked in brick pits, coped with fone or oak, about twelve feet wide and two and a half deep: the length thould be according to the number of frames that you work. The fize of the lights, for early Melons, thould be five feet long, and three broad; but for others they will require to be fix feet long, and four broad. The former fhould be four and the latter three light boxes. For the pits, a nineinch wall will be fufficient; and if they are intended for a wood coping, the bricklayer mut build in fome pieces of timber to faften it to: but where ftone can be had at a reafonable rate, 1 would give it the preference, as wood rots very foon.

There fhould be a walk between the ridges, about fix or feven feet broad, fufficient to admit a cart to carry dung, which will be much more expeditious than wheeling. The walk thould be made up as high as the coping, and floping gently towards each end; the bottom thould be filled up and covered as before directed : this will be eafily kept clean; fo that, after your linings are made up, it may be kept as neat as if it were in a pleafure-ground.

It will be neceffary to make a loofe drain along the middle of the bottom of the pit, to convey away any wet, ard the oozing from the dung, to a ciftern, or tank, made on purpofe to receive it. This moifture, which is the ftrength of the dung, may be ufed for watering Cabbage-plants, Cauliflowers, \&c. or it may be thrown on the ground for manure. I have experienced it to be much better than dung.

When a garden is planted and finifhed, it will be found very convenient to have a plan of it, with the name of each tree inferted in its proper place. This I had done when the 
new llips were laid out in Kenfington-gardens about ten or eleven years ago, and have found it of great fervice.

Walls of Kitchen-gardens thould be from ten to fourteen feet high; the foundation thould be two bricks or two bricks and a half thick; the offset thould not be above one courfe higher than the level of the border; and the wall thould then fet off a brick and a half thick. If the walls are long, it will be neceffary to ftrengthen them with piers from forty to fixty feet apart; and thefe piers thould not project above half a brick beyond the wall. I do not approve of fixed copings, efpecially when they project fo far as they are generally made to do; I would rather advife to have a moveable wooden coping, fixed on with iron hooks faftened to pieces of wood built into the top of the wall: thefe copings would alfo be found very convenient to faften the nettings, \&c. to in Spring, for theltering the fruit-trees. If, however, any thould prefer fixed copings, they thould not project above an inch on each fide of the wall; this fmall projection will be fufficient to preferve the wall, and will not prevent the dew and rain from falling on the upper parts of the trees, which is of great fervice to them. Some copings are made of bricks convex on the upper fide: but I have lately feen a very good coping at Afhted-Park, near Epfom: it is made of a fort of Welch llate, to be had, of different fizes, at Mr. Samuel Wyatt's flate-yard, Chriftchurch, near Blackfriar's Bridge. This is made to project about one inch, and anfwers exceedingly well. Flat copings thould have a litlle Nope towards the North or Eaft, according to the axpect of the wall; this will carry the wet from the South and Weft fides, which otherwife would be apt to injure the early 
early bloffoms and fruit on the South and Weft walls in cold nights.

When bricks can be had, I would advife never to build garden walls of ftone; as it is by no means fo favourable to the ripening of fruit as brick. When a kitchen-garden contains four acres, or upwards, it may be interfected by two or more crofs-walls, which will greatly augment the quantity of fruit, and alfo keep the garden warm and fhelter it greatly from high winds. 


\section{CHAPTER XXIV.}

THE ORCHARD.

Its Size, Situation, and Soil-Choice of Trees, preparing the Ground, Planting, \&c.-An annual Wafh for Trees.

ORChARDS are appropriated to the growth of ftandard fruit-trees only, where a large fupply of fruit is wanted; and generally confint of Apple-trees, Pear-trees, Plum-trees, and Cherry-trees; but a complete orchard thould have, befides, Quinces, Medlars, Mulberries, Service-trees, Filberts, Sparilh Nuts, and Barberries; as alfo Walnuts and Chefnuts; the two latter of which are well adapted for Theltering the others from high winds, and thould therefore be planted in the boundaries of the orchard, a little clofer than ordinary, for that purpofe In chocfing your trees, too much care cannot be taken to admit of none but fuch as have good roots, fair clean ftems, and proper heads. In felecting your Pears and Apples, efpecially the latter, be careful to procure a proper affortment for the fupply of your table during the whole year: a very few of 
the Summer forts will fuffice; more of the Autumn, and fill more of the Winter will be required; as upon this laft you muft chiefly depend for fupply from the month of January to July. See the Meibod of preferving Fruit, in CHAoter XXV.

In cyder-making counties, fuch as Hereford, Worcefter, Gloucefter, Somerfet, and Devon, they have large orchards of Apples; and in fome counties, (Kent in particular) there are orchards wholly of cherries. In gencral orchards, however, there ought to be a much larger proportion of Apples than of any other fruit. Orchards, in proper fituations, are very profitable; befide, the trees have a delightful appearance when in bloffom, and alfo when the fruit is ripe.

What has been faid refpecting the fituation and foil of a garden is alfo applicable to an orchard. The fituation of an orchard thould be rather elevated than low; on a gentle declivity; and open to the South and South Eaft, to give free admiffion to the air and rays of the fun (to dry up the damps and difperfe the fogs), which will render the trees healthy; and give a fine flavour to the fruit. An orchard thould alfo be well theltered from the Eaft, North, and Wefterly winds, by plantations, if not naturally theltered by rifing grounds. Theie pluntations of foreft-trees fhould neither be too large nor too near the orchard; as they would in that cafe prevent a free circulation of the air, which. would prove injurious to the fruit-trees. But, if the ground will not admit of fuch plantations, I would advife planting crofs rows of fruit-trees, as direeted for gardens. I would alfo recommend planting fcme of the largent growing trees neareft the outfides expofed to thofe winds; two or three rows of which fhould be planted clofer than ordinary, which would greatly thelter thoie in the G G. 2 interior: 
interior parts of the orchard. Walnut and Chefnut trees, as has been already obferved, are well adapted for th is pupofe.

As to the fize of an orchard, it may be from one to twenty acres, or more, according to the quantity of fruit wanted, or the quantity of ground that you may have fit for the purpofe.

That foil which produces good crops of corn, grafs, or garden vegetables, will alfo do for an orchard; but a loamy foil is to be preferred; though any of a good quality, not too light or dry, nor wet, heavy, or fubborn, but of a moderately foft and pliant nature, will be found to anfwer the end. Shingly and gravelly foils difagree very much with fruit-trees, unlefs there be loam intermixed *. They' will fucceed much better on a chalk bottom. On fuch a foil, I have feen roots twelve feet deep, and trees thrive well. If the bottom be clay, the roots thould be cut-in once in four years, to prevent them from penetrating the clay, which would greatly injure the trees. The foil hould be from two to three feet deep; before planting the trees, it fhould be trenched two fpits deep, and ten feet broad where the rows are to be planted, and a fpit below loofened, unlefs it be clay, which thould be trodden down. If it be pafture ground, it hould be ploughed, and well fummer-fallowed, till the grafs be killed, otherwife when it is laid in the bottom in trenching, which it generally is, it will be very apt to breed grubs, which will do much mifchief.

* Where no better is to be had, the holes thould be dug at leaft three feet deep, and filled up with good mould; if mixed up with rotten dung, rotten leaves, or other manure, the trees will in time amply repay the expence: the dung ufed for this purpore Thould be that from the Melon and Cucumber beds, mixed with the mould from the fame, when the beds are broken up in Antumn, or Winter; it fhould be laid up in heaps, and continue fo for one year at leaft; but thonld be frequently turned and have fome good frefl mould mixed with it. 
Some only dig holes large enough to receive the roots, efpecially in grafs ground which is to be continued fo. Others prepare the ground by deep ploughing, if the orchard is to be of great extent. The fward, if pafture, hhould be ploughed-in fome time in Spring: give it a good fummerfallow, ploughing it two or three times, which will rot the turf. A fortnight or three weeks before planting, give the ground a good deep ploughing to prepare it for the reception of the trees. The beft time for planting on a dry foil is in October; but, if wet, the latter end of February, or the month of March, will be a fitter feafon.

In planting, endeavour to fuit the trees as well as poffible to the foil, and to plant them at proper diftances from each other; which may be from forty to eighty feet, according to the fize of the trees when full-grown. Fruit-trees, as has already been obferved, when planted too thick, are very liable to blights, and to be covered with mofs, which robs the tree of a great part of its nourifhment, befides fpoiling the flavour of the fruit. Procure your trees from a foil nearly fimilar to, or rather worfe than that where you intend to plant them; for trees tranfplanted from a rich foil to a poorer never thrive well, but if from a poor to a richer foil, they will generally fucceed.

If trees are planted in the quincunx order, and at the diftance of eighty feet, the ground between the rows may be ploughed and fown with Wheat, Turnips, \&c. or planted with Potatoes. Plowing or digging the ground, provided it be not done fo deep as to hurt the roots, by admitting the fun and rain to meliorate the ground, will keep the trees in a healthy flourifhing ftate. It will be neceffary to fupport the young trees by tying them to fakes until they are weli rooted, to prevent their being loofened or blown down by the wind.

The 
The Spring after planting, if it prove dry, dig up fome turf, and lay it round the ftem of the young trees with the graffy fide downwards; this will keep the ground moit, and fave a deal of watering: if the trees have taken well, this need not be: repeated, as they will be out of danger the firft year. The turf thould be laid as far as you think the roots of the trees extend; and when it is rotted, it thould be dug in, which. will be of great fervice to them.

Trees that are of very different fizes when full grown thould. not be planted promifcuoufly; but, if the foil be properly. adapted, plant the larger in the back part or higher ground, or at the North ends of the rows, if they run nearly North and South, and the others in fucceffion according to their. fize. Fruit-trees planted in this manner will have-a fine effeet when grown up; but if they are planted promifcuoufly, they will not appear fo agreeable to the eye: and, befides, the fmaller trees will be fhaded by the larger, which will. injure them, and fpoil the flavour of the fruit.

Orchards thould be dunged once in two or three years. The ftems of trees in thofe where cattle feed thould be high. enough to prevent their eating the lower branches; and fenced in fuch a manner as to prevent their being barked, or. injured, by the cattle rubbing againft them, particularly. when young; which may be done by triangles of wood, or the trees may be buthed with thorns, \&c. The trees are to be pruned: and managed as already directed for Apples, Pears, Plums, $\& c$. \&c.

If the foil be wet, it muft be drained, as already directed: for a garden. When the furface of the ground is wet, and. has a little defcent, it may be formed into a kind of ridges, by making a furrow, from one foot to two deep, between: 
esery two rows, floping the ground regularly on each fide, from a reafonable diftance to the bottom of the furrow. Thefe hollows will carry off the water, and render the furface dry and healthy. If pafture, the turf may be firft pared off, and afterwards re-laid when the furrow is made.

In orchards, where cattle are not permitted to go, I would prefer dwarf-trees to ftandards, taking care to proportion the diftance of the rows to the fize of the trees. But in orchards kept for pafture it will be neceffary to plant ftandards.

Burning of rotten wood, weeds, potatoe haulm, wet ftraw, \&c. on the windward fide of the trees when they are in bloffom, will be found a good prefervative from blights, caterpillars, \&c.

I would recommend wanhing the trees annually, in the month of February or March, with the following mixture, which will deftroy the eggs of infects, and prevent mofs from growing on the trunks and branches: it will alfo help to nourith the tree, keeping the bark fine and healthy ; and will have the fame effect on it as a top dreffing has upon grafs land.

Mix frefh cow-dung with urine and foap-fuds, and with this mixture wafh over the ftems and branches of the trees, as a whitewather would wan the cieling or walls of a room; taking care to cut off all the cankery parts, and to fcrape off all the mofs, before you lay the mixture on. In the courfe of the Spring or Summer, you will fee a fine new bark coming on. When the old bark is cankery, you muft pare it off with a draw-knife, or fuch a long knife as I have had made on purpofe, efpecially for wall-trees, where the draw-knife cannot be applied, next the wall. The knives and other tools 
for dreffing decayed trees will be defcribed hereafter *. When you fee it neceffary to take all the outer bark off, you muft cover the ftem, \&c. with the Compofition and powder, patting it gently down, as in the cafe when large limbs are cut off.

If the above walh be repeated in Autumn, after the fall of the leaf, it will deftroy the eggs of a great many infects that hatch in Autumn and Winter. This wafhing will be found, of great fervice to all kinds of fruit and foreft trees whatever. 


\section{CHAPTER XXV。}

\section{OF GATHERING APPLES AND PEARS.}

The Time and Manner of Gathering them; and of the Management of the Fruit-room-Of Packing Fruit for Carriage.

As Apples thaken or beaten down with a pole never keep in Winter, they ought all to be hand-picked by a perifon ftanding on fteps made on purpofe.

The fteps fhould be light, for convenience of moving from one place to another; and fo contrived, that the ladder may be difengaged from the back at pleafure; which may eafily be done if they are faitened together by a bolt at top. There thould be a broad ftep at top to ftand on, with room for the bafket which is to hold the fruit. When you begin to gather the fruit, you thould be provided with hand-bafkets of different fizes, and alfo with large bafkets, or hampers, and wheelbarrows. You muft lay fome fhort-grafs mowings, perfectly dry, (which you ought to provide for the purpofe in Summer, and keep in a thed or any other dry place till wanted) at the 
bottoms of the large bafkets and hampers, to prevent the fruit from being bruifed.

Obferve attentively when the Apples and Pears are ripe: and do not pick them always at the fame regular time of the year, as is the practice with many. A dry feafon will forward: the ripening of fruit, and a wet one retard it; fo that there will fometimes be a month or five weeks difference in the proper time of gathering. The method that I have practifed is, to obferve when the fruit begins to fall ( $\mathrm{I}$ do not mean what we call wind-falls, or the falling of fuch as are inferted with the caterpillar, \&c.), but found fruit; I then put my hand under it; and, if it comes off without any force being. ufed, I take it for granted that the fruit is perfectly ripe; unlefs the tree be fickly, which is eafily known by the leaves or fruit being thriveled. If the foregoing obfervations are attended to, the fruit will keep well, and be plump; and not fhriveled, as is the cafe with all fruit that is gathered before it is ripe.

The perfon on the fteps fhould pick the fruit carefully, and lay it gently into the bafket on the top of the fteps; for if it be in the leaft bruifed it will not keep. For the fame reafon, great care munt be taken in emptying the fruit out of the hand-bafkets, when full, into the large bafkets or hampers. If more than one large bafket be wheeled at once, which may generally be done; the lower ones muft not be fo full as to let the bottom of the upper one touch the fruit: it will alfo be neceffary to put fome of the foft dry grafs between the bafkets, and alfo over the fruit in the upper bafket.

When the fruit begins to fall of itfelf, cover the ground: ander the tree with fome of the thort grais mowings, or, if that cannot be procured, with fome peafe-haulm, or oat or 
barley ftraw, quite dry: this will preferve the fruit from bruifing when it drops: the fruit which thus falls of itfelf fhould be laid up feparate from, and ufed before that which is hand-picked, according to the feafon in which they are fit to be fent to table. Should any be bruifed by falling on one another, they fhould be thrown afide, as only fit for baking, or to be given to the pigs.

When all the fruit is gathered in, rake off the thort grafs, \&c. and throw it up to rot, or mix it with dung, or leaves of trees; for if it remain on the ground during the Winter it will harbour flugs.

When the bolt of the fteps is taken out, and the ladder and back part feparated, the ladder will then be fit to ufe in gathering fruit off wall trees; only it will be neceffary to fcrew on the upper part of it two pieces of iron, or nail two pieces of afh or oak, about fix or eight inches'long, to keep it far enough from the wall to prevent the tree from fuftaining any damage in the bark or branches; which would infallibly bring on the canker.

When the fruit is carried to the fruit-room, lay fome of the dry thort grafs on the floor in the area of the room; then take the fruit gently out of the bafkets, and lay it in heaps on the top of the grafs, keeping each fort in a feparate heap; the heaps may be from two to three feet high, or according to the quantity of fruit that you have. When the heaps are completed, cover the tops at leaft two inches thick with Ihort grafs, in order to fweat them. Let them lie.a fortnight, then open the heaps and turn them over, wiping each Apple or Pear with a dry woollen cloth, which thould be frequently dried during the procefs, obferving now to lay in the middle the fruit which beforc was at the top. Let the heaps now 
remain eight or ten cays, covered as before; by that time they will have thrown out the watery crudities which they may have imbibed during a wet feafon; then uncover the heaps, and wipe the fruit carefully one by one, as before; picking out every one that is injured, or has the leaft fpot, as. unfit for keeping.

Fruit thould be gathered, if poffible, in dry weather, and when the dew is exhaled from off the trees; and remember: never to gather in the evening after the dew begins to fall.

During: the time that the fruit is fweating, the windows: thould be left open, except in wet and foggy weather, to admit the air to carry off the mointure which perfpires from the fruit. The perfpiration will fometimes be fo great, that on putting your hand into the heap, it will come out as wet as if it had been dipped into a pail of water: when in this ftate, it will be neceffary to turn and wipe the fruit.

In laying-up fruit, the common praetice has been to lay it on clean wheat-ftraw; but I find by experience, that when any of the fruit begins to decay, if it be not immediately. picked out, the ftraw, by imbibing the moifure from the decayed fruit, will become tainted, and communicate a difagreeable tafte to the found fruit:

I would likewife caution thofe who erect new fhelves in their fruit-rooms, to have the timber well feafoned, and to make ufe of white deal in preference to red, as the latter, efpecially if not very well feafoned, is apt to give a very difagreeable refinous tafte to the fruit, which quite fpoils its flavour. I would, therefore, recommend covering the bottoms of the finelves with thin coarfe canvas (fuch as may be purchafed for about eight or ten pence a yard), on which the fruit thould be laid in a fingle layer, after being wiped per- 
feetly dry; but by no means lay them atop of one another. When that is done, cover them with a piece of the famecanvas, or thin flannel, or with old news-papers, or whitifh brown paper, which will in a great meafure exclude the air, prevent the froft from injuring the fruit, and preferve a beautiful fmoothnefs on its $\mathrm{fkin}$. The fruit thould be turned two or three times during the Winter; as delicate and tender fruit, by lying long without turning, is apt to rot on the underfide, even if perfectly found when laid-up. Be particularly careful, however, to pick out all the damaged fruit.

When the fruit is laid-in, put the earlieft forts on the lower. Relves, or in the lower drawers, according to their time of coming in, beginning with the Nonefuch, Golden Rennet and Jenneting Apples, and Bergamot and Beurré Pears (for I find by experience, that the Jargonelle keeps beft on the tree, as, if gathered, it rots almort immediately); thus, by proper management, you may have a conftant fuccefion of fruit from one feafon to the other.

When there are large quantities of fruit, it will require a great deal of time to lay it on the fhelves, \&c: : this bufinefs may therefore be done in wet weather, or in the evenings, when you cannot conveniently fpare your men from the outdoor-work in the day-time.

Thofe who keep their fruit in ftorehoufes, for the fupply of the London and other markets, as well as thofe who have not proper fruit-rooms, may keep their Apples and Pears in bafkets or hampers; putting fome foft paper in the bottoms and round the edges of the bafkets, \&c. to keep the fruit from being bruifed; then put in a layer of fruit, and over that another layer of paper; and fo on, a layer of fruit and of pape: alternately, till the bafket or hamper be full: cover the top 
with paper three or four times double, to exclude the air and froft as much as poffible. Every different fort of fruit thould be packed feparately; and it will be proper to fix a label to each bafket or hamper, with the name of the fruit that it contains, and the time of its being fit for ufe.

But the beft way of keeping fruit is, to pack it in glazed earthen jars. The Pears or Apples mut be feparately wrapped up in foft paper, then put a little well dried bran in the bottom of the jar, and over the bran a layer of fruit; then a little more bran to fill up the interftices between the fruit, and to cover it; and fo on, a layer of fruit and of bran alternately, till the jar be full; then fhake it gently, which will make the fruit and bran fink a little; fill up the vacancy at top with more bran, and lay fome paper over it, covering the top with a piece of bladder, to exclude the air; then put on the top or cover of the jar, obferving that it fits as clofely as poffible. Thefe jars thould be kept in a room where you can have a fire in wet or damp weather.

\section{Of Packing Fruit for Carriage.}

If fruit be to be fent to any confiderable diftance, great care Thould be taken in packing it: which thould not be in bafkets, as they are liable to be bruifed among heavy luggage, and the fruit, of courfe, will be injured. I would, therefore, recommend boxes made of ftrong deal, of different fizes according to the quantity of fruit to be packed. The following are the dimenfions of the boxes in which we fend fruit by the Coach to Windfor and Weymouth, for the ufe of his Majefty and the Royal family: viz. 
The larger box is two feet long, fourteen inches broad, and the fame in depth. The fmaller box is one foot nine inches long, one foot broad, and the fame deep. 'Thefe boxes are. made of inch deal, and well fecured with three iron clamps at each corner; they have two fmall iron handles, one at each end, by which they are faftened to the roof of the coach: in thefe boxes we fend Melons, Currants, Pears, Peaches; Nectarines, Plums, and Grapes, packed fo as always to have the heavieft fruit at bottom. The Melons are wrapped up in foft paper, the Pears, Peaches, Nectarines, Plums, and Grapes, are firft wrapped up in Vine-leaves, and then in paper. The Cherries and Currants are packed in a flat tin. box one foot four inches long, ten inches broad, and four deep.

In packing, proceed thus:-Firft, put a layer of fine long: dry mofs in the bottom of the tin box, then a layer of Currants or Cherries, then another layer of mofs; and fo on, alternately fruit and mofs, until the box is fo full, that when the lid is hafped down the fruit may be fo firmly packed as to preferve them from friction.

Make a layer of fine mofs and thort foft dry grafs, well mixed, in the bottom of the deal box; then pack in the Melons with fome of the fame, packing it tight in between all the rows, and alfo between the Melons in the fame row, till you have finifhed the layer; choofing the fruit as nearly of a fize as poffible, filling up every interftice with the mofs and grafs. When the Melons are packed, lay a thin layer of mofs and grafs over them, upon which place the tin box with the Currants, packing it firmly all round with mofs to prevent it from thaking; then put a thin layer of mols over the box, and pack the Pears firmly (but fo as not to bruife them) 
on that layer, in the fame manner as the Melons; and fo on with the Peaches, Nectarines, Plums, and, laftly, the Grapes, filling up the box with mofs, that the lid may fhut down fo. tight as to prevent any friction among the fruit. The boxes thould have locks, and two keys, which may ferve for them all; each of the perfons who pack and unpack the fruit having a key.

The mofs and grafs thould always be returned in the boxes, which, with a little addition, will ferve the whole feafon, being thaken up and well aired after each journey, and keeping it fweet and clean. After the wooden box is locked. it will be neceffary to cord it firmly.

My reafon for being fo particular on packing of fruit is, that I have known inftances of its being totally fpoiled in the carriage from improper packing.

By purfuing the above method we have never failed of fuccefs; and if fruit be packed according to the foregoing directions, it may be fent to the farthert parts of the kingdom, by coaches or waggons, with perfect fafety. 


\title{
CHAPTER XXVI.
}

\author{
OF THE CANKER, AND GUM.
}

A Defcription of the Canker; its Origin and Progrefs- Full Directions for Curing it-Of the Gum and its Remedy.

THE canker is a difeafe incident to trees, which occaifons the bark to grow rough and fcabby, and turns the wood affected to a rufty brown colour. This difeafe, if no remedy be applied, will in time totally kill the tree.

Apple-trees are very liable to be infected with the canker from the following caufes, viz:

From injudicious pruning; from the footfalks of the fruit being left on the trees, and from injurics funtained by applying ladders in gathering the fruit; thefe injuries are very hurtful to the tree, and will infallibly bring on the canker when no remedy is applied. A man ought to ftand on fteps, inftead of a ladder, when the fruit is out of his reach from the ground. Care fhould alfo be taken in naling, that the fhreds be not too tight, which caufes a fwelling in the thoot, and very of ten produces the canker. 
Another caufe of the canker is, when we have very wet Autumns, fuch as that of 1799 , which prevents the young wood from ripening, and a hard froft fetting in after it kills the young thoots: thefe, if left on the tree, will bring on the canker, and increafe it rapidly. Birds and infects devouring the buds will have the fame effect.

Carelefs people frequently leave the dead thoots on the tree throughout the Summer, which will infallibly bring on the canker. Some even leave them for years, until the tree is totally killed. They thould be cut off in the end of April, or beginning of May; as by that time you will be able to fee how far the difeafe has advanced. I would advife to cut two or three buds, or even more, below the apparently difeafed part, as the canker frequently reaches a great way farther in the heart of the thoot than it appears to do on the outfide: you muft cut down till the brown colour in the thoot difappears, and nothing remains but found white wood.

The truth of the foregoing obfervations will appear evident to any perfon who takes notice of the Apple-trees with their mutilated ftag-looking heads, as he rides or walks along the road.

It is a general opinion, that the canker in all trees proceeds from the nature of the ground in which they are planted; fuch as a four clay, a thingly or gravelly foil, \&rc.

My late and much efteemed friend Mr. Hudfon, author of the "Flora Anglica," was of this opinion, till I convinced him of the contrary by fome experiments made at Nutwell, near Exeter, the feat of the late Sir Francis Drake, a gentleman very fond of gardening and agriculture. Mr. Hudfon faid, it would be to no purpofe to make any attempt to cure the Apple-trees, as the ground was of fuch a nature as to bring 
on the canker. The trees were, indeed, in a fad condition, being covered all over with lichens and mofs, and very much infected with the canker. I requented Mr. Hudfon to fix on fome of the worft; we then defired the gardener to open the ground round their roots, which we found perfectly found, the bark of them fmooth, and not the leaft appearance of the canker to be feen.

The canker, as before obferved, proceeds from bruifes in the bark, from limbs cut off, \&c. When thefe limbs begin to rot and grow hollow, they convey the canker to the root; for it always proceeds from the branches and ftem to the roots, and never from the roots to the tree.

It is granted, however, that all fruit-trees love a fine rich mellow loam, and thrive much better in it than in a fhingly or gravelly foil.

When by accident, or improper treatment, trees receive large wounds, and the cure is left to nature, they are frequently overrun with gum and canker, which, if not checked, will in a thort time totally ruin them.

In this cafe you muft carefully pare off, with a draw-knife, or any other convenient inftrument, all the difeafed part of the bark. The inner white bark is frequently infected; this muft alfo be cut away till no appearance of infection remains. The infection in the inner bark appears like dots made with a pen, all of which muft be cut clean out; for, if any part of the canker be left, it will infect the new wood and bark. Whereever you fee gum oozing out, you may reft affured that the canker is not quite eradicated; which, if fuffered to remain, will fpread till the whole tree becomes a mafs of gum and canker, and will be killed in a very thort time. 
When the trunk is become hollow, cut the loofe rotten part clean out till you come to the found wood, taking care to round the edges of the hollow part; then apply the Compofition in a liquid ftate, laying it on with a painter's brufh wherever the cankered bark has been pared off or the dead wood cut out, till thefe places are entirely covered with it : when that is done, thake fome of the powder of wood-athes and burnt bones over the Compofition, and pat it gently down with your hand. See the Chapter ON THE MAKing AND LAYing ON OF THE COMPOSITION.

If the foregoing directions be carefully followed, the canker will be completely eradicated, and the hollow trunk in time be. filled up with found wood.

When the ftem is much decayed, it will be abfolutely neccffary to open the ground, examine the roots, and cut off all the rotten parts. When you have cut out all the rotten and decayed parts below ground, and fcraped the hollow clean, make up a mafs of the Compofition mixed with fome clay, like what is ufed for grafting; then fill the hollow part with it to within about two inches of the furface of the ground, treading it in with your foot, or preffing it in with the hand, as clofe "as you poffibly can, to prevent the wet from penetrating to the roots, and leave the furface of the Compofition floping from the tree towards the outfide of the border, to throw the wet off, which will prevent the frefh part of the root from rotting; then cover the root over with mould level with the reft of the border.

When you have examined all the old wounds where large limbs have been cut off, you thould next examine the old bark; and, if you find the outfide of it wrinkled and cracked, 
pare it off, as it is always, when in that ftate, very much hurt by the canker. This thould be done with the draw-knife, or other, harp inftrument; then apply the Compofition as before directed, which will bring on a fine fmooth bark under it. In the fucceeding Winter, or Spring, you will fee all the plafter, with the old part of the bark that was left in the hollow parts of the tree, or where old branches had been amputated, peeling off and fhewing the fmooth bark underneath. You thould then fcrape off, with a wooden or bone knife, what old bark remains in the hollows where the draw-knife could not reach without cutting too much away. When that is done, mix up fome freth cow-dung with foap-fuds and urine, making it very thin, and give the tree a coat of this mixture all over where the bark has been fcraped off: the cow-dung will adhere to it, and heal the parts where you were obliged: to fcrape to the inner bark. This wafh will remain till the frefh bark comes on; then it will be difcharged of itfelf during the Summer, or the next Spring, leaving a new frefh fmooth bark where the old and cankery was taken off. Next. Spring, if any of the old bark remains, you may repeat the fame operation, which will caufe all the remaining old bark. to flough off like a fcab from a wound on the human body. By thefe means you will keep your trees in a fine flourifhing healthy ftate, and, in general, prevent them from becoming bark-bound. If any of them, notwithftanding, thould be bark-bound, you muft farify them, by taking a tharp knife, and running the point of it Atraight down the middle of the ftem from top to bottom; taking care to run your knife through the outer bark only; then, with a bruth, or your. finger, rub in fome of the Compofition, to prevent the incifion from bringing on the canker. This operation will. caufe the tree to expand the bark and become very flourifhing. 
Remember to cut off all the ends of the fmall thoots where the canker had injured them laft year. Cut off alfo the old fruit-ftalks, and all the fmall dead ftubs, which, if left, will never fail to bring on the canker.

The rough or cankery bark on that fide of trees which is next the wall thould be fcraped or pared off with a tool made in the form of a fickle, which, with other tools, will be defcribed hereafter.

It is much to be regretted, that fruit-trees in general throughout this kingdom are in a mutilated unfruitful ftate. After Gentlemen have purchafed the young trees from Nurferies, and planted them in their orchards and gardens, they think every thing neceffary is done; when, in fact, the greater part of the work is yet to come. In packing and carriage, the ftems and branches are very frequently bruifed; in that cafe, the injured parts of the bark and wood muit be carefully cut out, and the Compofition immediately applied: this may be done when you head the trees, which operation fhould be performed in April, May, or even June, when the bud begins to thoot; but by no means cut off any of the fhoots, except thofe that are broken or bruifed very much. When this is neglected, the canker will follow, to the great injury, if not the death, of the trees. How common is it to fee, in all parts of the country, great numbers of trees fo affected with this difeafe as not to produce fruit enough in twelve or fourteen years to pay half the expence attending them! whereas, if they were to be managed according to the foregoing directions, they would more than pay all the expence in three years. It is common, when young trees do not thrive, either to blame the nurferyman for fending bad or difeafed trees, or to attribute their unthriving ftate to the 
nature of the foil ; whereas the fact is, that this frequently arifes from the inattention or mifmanagement of the perfon who plants and fuperintends them. If the injured and difeafed parts be not cut out at an early period, the trees will not thrive, but will become cankery and ftunted, and cannot be recovered afterwards without a great deal of labour and. trouble; whereas, if the directions given for heading trees the firit year, and cutting out the difeafed parts, be attended to, the trees will flourith, and bear large crops of fine and: well-flavoured fruit.

\section{The Gum.}

The Gum is a kind of gangrene incident to fruit-trees of the ftone kind, and arifes from the following caufes: from injudicious pruning, from bruifes, or any injuries received in the wood or bark. This may happen from ftrokes of the hammer in nailing, from pinching the fhoots by nailing the Threds too tight, or by driving the nails too clofe to the branches. It may alfo be occafioned by leaving the footftalks of the fruit, or by pruning in Summer and cutting the fhoots to thort ftumps, and by injuries fuftained by a carelefs application of ladders in nailing and gathering the fruit, \&c. but it particularly originates where large limbs have been lopped or broken off. This difeafe may be known before the gum itfelf makes its appearance. The bark at firt becomes of a brownifh colour, which gradually grows darker, till at laft the gum begins to ooze out like little blifters. As foon as any of thefe fymptoms are obferved, the infected part fhould be cut out with a tharp inftrument, and the Compofition and: 
powder applied immediately. You mut obferve to cut out the gum perfectly clean; you will fee it oozing out from between the wood and bark: this muft be followed till you come to the white clean bark and wood. If afterwards any gum fhould make its appearance, it munt be fcraped off; which is beft done when it is moiftened with rain, as you can then fcrape it off eafily without hurting the bark. This muft be done without delay, otherwife the difeafe will rapidly advance.

When trees are hollow, it will be neceffary to examine them carefully to fee whether any grubs have entered the bark and wood, which you will know by their perforating the bark. If there be any, they muft be carefully cut out before the Compofition is applied. 


\section{(24)}

\section{CHAPTER XXVII.}

OF THE MILDEW, HONEY-DEW, AND BLIGHTS.

A Defcription of the Mildere, and a Remedy for it-Of the Honeydere and its Remiedy-A Defcription of different Sorts of Blights. and the beft Means of preventing them.

\section{Of the Mildere.}

THE Mildew, a difeafe very hurtful to plants, is a kind of thick clammy moifture, which falls on, or rather tranfpires from, the leaves and bloffoms of plants. This clammy fubftance, by ftopping up the pores, prevents perfpiration, and hinders the growth of the plant. But what is commonly called mildew is an infect which is frequently found in vaft numbers feeding upon this moifture. Mr. T. S. Segar, in a treatife upon this fubject, fays, that the mildew is of a very tharp corrofive nature, and by its acrimony hinders the circulation of the nutritious fap; in confequence of which the leaves begin to fade, and the bloffoms and fruit are greatly injured.

$\mathrm{K} \mathrm{K}$

I have 
I have obferved that, contrary to the common opinion, trees are more liable to mildew on South and Weft walls, than on an Eaft wall; and I have frequently removed fuch trees from a South or Weft wall, to a North or Eaft wall, where they have perfectly recovered.

Whenever you apprehend danger, wath or fprinkle the trees well with urine and lime-water mixed; and when the young and tender thoots are much infected, it will be neceffary to wafh them well with a woollen cloth dipped in the following mixture, fo as to clear them of all the glutinous matter, that their refpiration and perfpiration may not be obftructed.

Take tobacco one pound, fulphur two pounds, unflaked lime one peck, and about a pound of elder-buds; pour on the above ingredients ten gallons of boiling water; cover it clofe, and let it ftand till cold; then add as much cold water as will fill a hogthead. It hould ftand two or three days to fettle: then take off the fcum, and it is fit for ufe.

\section{Of the Honey-Dew.}

The Honey-Dew is a fweet faccharine fubftance found on the leaves of certain trees, and is generally fuppofed to fall from heaven like dew : but this is a miftaken opinion. One kind of honey-dew tranfpires from the leaves of the trees where it is found: and the other is the excrement of a fmall infect called a vine-fretter, a fpecies of Aphis. Bees and ants are very fond of both thefe kinds of honey-dew.

As the honey-dew, by its vifcous quality, clofes up the pores, and ftops the perfpiration of trees, it muft of courfe be 
very hurtful to them. This difeafe thould be treated in the fame manner as the mildew; but, as has been already obferved, trees thould be watered, or wathed, early enough in the day to get dry before the cold of the night comes on; nor mould it be done while the fun thines very hot, which would be likely to foorch the bloffoms and leaves.

\section{Of Blights.}

Blights are very deftructive to fruit-trees, fometimes deftroying the whole tree; but more frequently the leaves and bloffoms, while the tree itfelf remains unhurt.

One caufe of the blight is, the continuance of a dry eafterly wind for feveral days together, which ftops the perfpiration in the tender bloffom; and a long continuance of the fame weather equally affects the tender leaves, caufing them to wither and decay: the perfpiring matter is thereby rendered thick and glutinous, and fo becomes food for thofe fmall infects which are always found in vaft numbers on fruit trees that are affected by this fort of blight.

Thefe infects, however, are not the original caufe, as fome imagine, but the natural confequence of blights; for wherever they meet with fuch a proper nutriment they multiply amazingly, and greatly promote the diftemper when no method is taken to prevent it.

The beft remedy for this diftemper that I know of is, to wafh them with urine and foapfuds, as before directed; and the fooner this is performed, whenever we apprehend danger, the better: if the young and tender hoots feem to be much infected, wath them with a woollen cloth dipped in the fame liquid that is recommended for the mildew. 
Another caufe of blights in the Spring will be found in tharp hoary frofts, which are often fucceeded by hot funfhine in the day time.; thefe are certain and fudden deftruction to the fruit. Sharp pinching frofty mornings, which often happen when the trees are in fiower, or while the fruit is very young, occafion the bloffoms or fruit to drop off, and fometimes greatly injure the tender thoots and leaves.

The only method yet found out to prevent this mifchief is, the carefully covering the walls with netting, \&c. as before directed *. The covering is to remain on during the night, and to be taken off in the day-time. This method has been reckoned of little fervice by fome, which, indeed, may be the cafe when the coverings are not properly ufed; for, if the trees are kept too long covered, the young branches and leaves will be fo weak as not to be able to bear the open air when they are expofed to it.

The fame confequences will follow when the trees are incautiounly expofed to the air after having been long covered.

Beat if the covering be properly performed, it will frequently preferve the fruits under it, when there happens almoft a general failure in the neighbourhood where this precaution has been neglected. The great trouble which feems to attend it may deter many from putting it in practice; yet if the nettings, or other coverings, be fo contrived as to draw: up and let down by means of pullies, the bufjnefs may be done with eafe and expedition; and the fuccers attending it will make ample amends.

But what is called a blight is frequently no more than a: weaknefs or diftemper in trees. This is the cafe when trees:

$$
\text { * P. 9, 10, } 3 \% \text {. }
$$


againf the fame wall, and enjoying the fame advantages in every refpect, differ greatly in their health and vigour, the weak ones appearing to be continually blighted, while the others remain in a flourifhing condition. This very great difference, in fuch circumftances, can be attributed only to the different conftitutions of the trees, proceeding from a want of proper nourifhment, or from fome bad qualities in the foil, fome diftemper in the ftock, buds, or cions, or from mifmanagement in the pruning, \&c. all of which are productive of diftempers in trees, of which they are with diffculty cured.

If the fault be in the foil, it muft be dug out, and frefh mould put in its place; or the trees muft be taken up, and others better adapted to the foil planted in their room. It will be found abfolutely neceffary always to endeavour to fuit the particular forts of fruits to the nature of the foil ; for it is in vain to expect all forts of fruit to be good in the fame foil.

If the weaknefs of the tree proceed from an inbred diftemper it will be advifable to remove it at once, and, after renewing the earth, to plant another in its place.

But if the weaknefs has been brought on by ill management in the pruning, which is frequently the cafe, I would advife the method of pruning and training which is laid down in this treatife to be adopted without lofs of time.

How common is it to fee the young luxuriant branches trained up to their full length every year, and fo carried to the top of the wall in a very fhort time! by which the fruitbearing branches are robbed of a great part of their nourifhment, which weakens them fo much that they have not ftrength to produce fruit; but the bloffoms fall off, and not unfrequently the branches decay, fometimes even their whole 
length, and this is afcribed to a blaft! Luxuriant fhoots fhould be ftopped, and all fuperfluous wood fhould be cut out: otherwife they will exhauft a great part of the nourifhment which fhould go to the fupport of the fruit-bearing branches.

There is another fort of blight that fometimes happens pretty late in the Spring, viz. in April and May, which is very deftructive to fruit-trees in orchards and open plantations, and againft which we know of no effectual remedy. This is what is called a fire-blaft, which in a few hours hath not only deftroyed the fruit and leaves, but often parts of trees, and fometimes entire trees have been killed by it.

This is generally thought to be occafioned by certain tranfparent flying vapours, which may fometimes take fuch forms as to converge the fun's rays in the manner of a burning-glafs, fo as to fcorch the plants they fall upon, and this in a greater or lefs degree in proportion to their convergency. As this generally happens in clofe plantations, where the vapours from the earth, and the perfpirations from the trees, are pent-in for want of a free circulation of air to difperfe them, it points out to us the only way yet known of guarding againft this enemy to fruits; namely, to make choice of a clear healthy fituation for kitchen-gardens, orchards, \& and to plant the trees at fuch a diftance as to give free admiffion to the air, that it may difpel thofe vapours before they are formed into fuch volumes as to occafion thefe blafts.

But blafts may alfo be occafioned by the reflection of the fun's rays from hollow clouds, which fometimes act as burning mirrors, and occafion exceffive heat. Againft this there is no remedy. 


\section{CHAPTER XXVII,}

OF INSECTS, \&c.

Of the different Sorts of Infects infefting Fruit-Trees, and the Method of deftroying them-How to preferve Fruit from Birds; and of deftroying Rats and Mice.

$$
\text { Of the Aphis*. }
$$

ApHIDES, or Plant-lice, are a very numerous and deftructive tribe of infects. Entomologifts enumerate 75 fpecies of them; but probably there are many more, as every tree infefted by them has a diftinct fpecies; ' and Linnæus names them from the different trees that they live upon; as the Currant aphis, the Plum aphis, the Cherry aphis, \&c. \&c. The males, which are very few in comparifon of the females, have wings; but the females are apterous, or without wings.

* Thofe who wifh for farther information refpecting infects, may confult Reaumur's Hiftory of Infects, or Dr. Anderfon's Recreations in Agriculture, Natural Hiftory, \&c.

Aphides 
Aphides are devoured by the larva of the Myrmeleon Formicarius, or ant-eater, of Linnæus. Ants are likewife very fond of them, on account of a fweet liquor which they eject from the anus. Aphides are extremely common.

Fruit-trees are frequently very much inferted with different fpecies of the aphis; the Plum, in particular, fuffers greatly by them. Thofe which I have moft frequently found on Plums are, the brown, the green, and the light fea-green aphis; but, as before obferved, different forts of trees generally have different fpecies of aphides. Great care thould be taken to deftroy thefe pernicious infects at as early a period of their growth as poffible; otherwife they will confume the leaves and fruit for that feafon. The beft method that I have found for this purpofe is, to take fome fine wood-athes mixed with one third part of fine unflaked lime, and throw it on with a common dredging-box, till you have covered the underfides of all the leaves where you find the infects: this fhould be done in the morning early while the dew is on the leaves, which will caufe the powder to adhere to them; letting them remain fo covered with the powdered lime for three or four days. Then mix unflaked lime and foft water, or water that has been expofed to the fun a week at leaft, at the rate of half a peck to thirty-two gallons, and fir it well two or three times a day for three or four days. If you have many trees that are infected with infects, mix up a large quantity in the fame proportion as the above. I generally mix as much at once as will fill a ciftern* about feven feet long by three and a half broad, and three feet deep, and that

* If it be a leaden ciftern, a little loam, enough to cover the bottom, muft be thrown in, and then trod down, before the lime and water are put in : the loam will prevent che lime from corroding the metal.

$\operatorname{con}=$ 
contains about $55^{\circ}$ gallons, which, according to the foregoing proportion, requires about two buthels and half a peck of lime. With this liquid, after the lime has fubfided, give the trees a good watering, obferving to throw a confiderable part of it under the leaves, by a barrow engine; this fhould be repeated once a day, for fix days, which will deftroy all the aphides. The engine that I would recommend is that of the late Mr. Winlaw's conftruction, which may be had of Meffrs. Chieflie and Yowle, No. 72, Margaret-Street, Cavendith Square.

If you find the infeets begin to make their appearance again, apply the powder as before directed, and repeat the watering.

Particular Directions for ufing the Lime-Water.

Take the clear water after the lime has fettled, fill the engine with it, and give the trees a good watering, throwing it with as much force as you can under the leaves; preffing your fore-finger over the mouth of the pipe to fpread the water like the falling of fmall rain, which you may very eafily do, at the fame time wheeling the engine backwards and forwards, that no part of the tree be miffed. This fhould be done in cloudy weather, or when the fun is off the wall. If the trees are on an Eaft wall, you may begin to water them about half paft eleven o'clock; if on a North wall, you may water them the firft thing you do in the morning; and if on a South wall, at four o'clock in the afternoon; repeating the watering for at leaft fix days fucceffively. But if there be cold Northerly and Eatterly winds, or frofty nights, the watering thould be difcontinued till the weather is milder.

$$
\text { L I }
$$


Be always careful that your trees get dry before night, and be fure never to water when the fun is on them; nor yet water them with the grounds of the lime, which will make the trees look very unfightly, and alfo injure the leaves.

When aphides are numerous at the ends of the thoots; the leaves there will be curled up; thefe fhould be all ftript off, and the infeets crufhed with the foot.

\section{Of the Acarus.}

The Acarus, or Red Spider, is one of the mort deftructive infects that can infeft plants, particularly in forcing-houfes.

Thefe infects have no wings, and the female is oviparous.

There are not lefs than 82 fpecies of this genus. The acarus is very common on trees, particularly the Currant, on the fruit of which it is frequently feen running.

Thefe infects attack the Vines, Nectarines, Peaches, and Cherries; and forced French-Beans are very fubject to their clepredations, as are alfo Peaches and Nectarines on the natural wall, in hot weather. Melons in frames are very much inferted with them. I once faw a ridge of Melons, of feventy lights, fo much injured by them, that when the fruit was full-grown, it was good for nothing, and the ftems and leaves were completely exhaufted of their moifture by thefe infects feeding on them. They are equally hurtful to moft exotics in hot-houfes.

The beft thing that I know for deftroying thefe pernicious infects is mointure; which will alfo deftroy many other infects in hot-houfes. 
Frequent watering of wall-trees, ftandards, \&c. with limewater (the making and ufing of which is defcribed in the directions for deftroying the aphis), and throwing it plentifully on the underfide of the leaves, where the acarus is generally found, will in a fhort time extirpate that deftructive infect.

For plants, \&cc. in hot-houfes, I would recommend ufing water only, and in the following manner:

Between three and four o'clock in the afternoon, fill the barrow engine with foft water, or fuch as has been expofed to the fur all day, and wheel it along the footpaths of the houfe, where they are wide enough to admit it, and fprinkle all the plants, preffing your finger on the top of the pipe to fpread the water.like a fine thower of rain, playing alfo againft the top lights and thelves till the water ftands an inch deep in the paths of the houfe*. If you cannot conveniently get the engine into the houfe, open the front lights, or, when there are no front lights, flide down the top lights, and throw the water in it at the front or top. When you begin this operation, if in the inflde, every light muft be fhut; and if you throw the water in at the front, you muft keep only one light open, which thut immediately when you have fufficiently watered that part of the houfe oppofite to it; and, then opening another light, proceed as before; and'fo on, till the whole is properly watered. The houfe mut then be kept clofe thut till next morning; this will caufe fuch an exhalation from, the glafs, tan, (if there are any tan-beds in the houfe,) \& c. that the plants will be covered all over with the vapour; which will infallibly deftroy the cocci, aphides, and

* I have lately feen a fmall copper engine, made by Mr. Philips, Engine-Maker, Blackfriars Road, which anfwers very well, when a barrow engine cannot be got into the houre. 
other infects: but the watering muft be repeated every afternoon, during hot weather only. By this you will alfo fave a great deal of labour in watering; but fuch plants as require much watering fhould be watered before you begin to fprinkle the houfe. Before morning the plants will have imbibed all the moifture, and the paths will be perfectly dry.

When I lived at the Botanic Gardens, Chelfea, I obferved in hard Winters, when we were obliged to keep ftrong fires in the ftoves night and day, that the plants which ftood on thelves in the dry ftoves were fo fcorched up that the leaves ufed to drop off, as from deciduous trees in Autumn, which gave them a very difagreeable appearance. This induced me to confider what could be done to prevent it; when the following method occurred to me: about eight in the morning; when the fun thone out, and there was the appearance of a fine day, 1 threw in water till it covered the floor, which was of tile, from one to two inches deep, and kept the houfe thut the whole of the day, unlefs the thermometer rofe to about eighty degrees, which feldom happens at that feafon of the year; in that cafe, I opened the door to admit a little air. By the middle of the day, the water was entirely exhaled, and the floor perfectly dry. This I ufed to repeat two or three times a week, in funny weather: the plants in about a week's time began to throw out their foliage, and in a fortnight or three weeks they were in full leaf. This fuccefs induced me to take the fame method with the tan ftoves and other houfes. in Summer, when troubled with infects; and 1 had the fatisfaction to find that it had the defired effect. 


\section{Of the Acarus on Melons.}

As we are now treating of infects, although it may look like a departure fro my original plan, I hope that fome inftructions for deftroying the red-fpider on Melons will not be unacceptable.

Melons, in dry weather, and with a dry heat, are very apt to be infefted with the red-fpider; and you may always obferve the fymptoms long before you can fee thefe infeets with the naked eye, by the leaves curling and cracking in the middle. Whenever you obferve them in that ftate, in fine warm funny weather, I would recommend watering them all over the leaves from a watering pot with a rofe, or an engine, about $f_{1} x$ in the morning; and about eight $o^{\prime}$ clock thade them with mats, if the fun mines, and thut the frames clofe down till about eleven; then admit a fmall quantity of air, letting the mats remain till about three in the afternoon, when they thould be taken off. Shading with mats will prevent the leaves from being fcorched by the fun while they are wet. If the wind be South, or South-Weft, I would recommend watering them again about three in the afternoon, fhutting them up clofe to keep the heat in, which will caufe a ftrong exhalation, and deftroy the fpiders, as they by no means love moifture. In watering, throw as much as poffible on the underfide of the leaves, where the infect generally lodges; the Vines may be gently turned, taking very great care not to hurt them; by which means you can eafily throw the water all over the underfide of the leaf; which mutt be done in a gentle hower from the engine, or from a watering-pot 
with a rofe, fo as not to warh up the mould on the plants: at the fame time throw great plenty of water on the lights and fides of the boxes. After you have done watering, lay the Vines gently down again in their former pofition. If a funny day, let the mats remain as before directed until the leaves of the plants are perfecly dry, admitting air according to the heat of the day.

Before the frames and lights are ufed, I would recommend warhing them well, both infide and out; firf, with clean water, and then with foap-fuds and urine mixed; ufing a brufh or woollen rag in the wathing; this will kill the eggs of the fpiders and other infeets that may have been depofited the preceding feafon.

When the ridges are fit for putting the mould on for the hills to plant the Melons in, it thould be from a foot to fifteen inches deep, and the reft of the bed thould be covered with light mould, or rotten leaves, about one inch deep to keep down the fteam. Take care not to make the hills too broad at firft (a wheel-barrow full and a half will be enough for one hill), and obferve that the heat is not too great, which will burn the mould and the roots of the plants. You will know when the beds are of a fine temperate heat, from fticks ftuck in at different parts of the bed, by the feel of your hand, and the fticks having a pleafant fweet fmell.

It will be very proper to water the hills, with a watering-pot having a rofe, once a day for two or three days before you put in the plants, keeping the lights thut, which will deftroy any eggs of the fpider that may yet remain in the crevices of the boxes and lights.

The day on which you mean to put in the plants, you chould give the beds a great deal of air, to let out the fteam 
that has been penned in; then turn over the hills, and put in your plants about three o'clock in the afternoon, making a hollow circle round the bottom of each hill, to feparate the mould of the hills from that on the bed, which will fuffer the fteam to evaporate more eafily; then watering the plants, thut them down till next morning, admitting air according to the heat of your bed, taking care not to give too much till your plants are well rooted in the hills, which will be in a couple of days; it will alfo be neceffary to fhade them in the heat of the day, to prevent the plants from flagging.

In cold frolty weather, you muft by no means fpriukle the plants, as the froft in the night will infallibly bring on the canker.

Soft water thould be ufed in fprinkling, or fuch as has been expofed feveral days to the fun. If the water be very hard, put fome wood-afhes into it, and fir it up two or three times a day : it will be fit for ufe in the courfe of two days; let the afhes fubfide, and ufe the clear water only.

If your Melons have been inferted with the fpider in the. preceding year, by no means ufe any of the mould again.

\section{Of the Coccus.}

The Coccus is a genus of infects belonging to the order Hemiptera, whofe males have wings, but the females have none.

The moft common infeets of this genus are thofe which attach themfelves to Peach, Nectarine, and Pear trees; and when full grown they have fomewhat the appearance of a boat with the keel turned uppermont. Thefe are apparently: 
without fect, eyes, or other members, while in this ftate; and fo much refemble fome kinds of galls, or excrefcences of the bark, as frequently to be taken for fuch. A thin film of a white cotton-like fubftance is interpofed between the flat part of the body and the tree. This is common, in a greater or leffer quantity, to all the fpecies, and appears at firft all round the edge as a kind of cement to join it to the tree.

The males are very few in proportion to the females, and not nearly one fourth of their fize; they are beautiful little flies, which, after a Mhort, but active life, terminate their exiftence without having tafted food, being provided with no lort of organs for that purpofe.

Peach, Neetarine, and Pear trees, are very much inferted with thefe infects: they frequently cut through the bark, and the trees then appear as if they had been fcratched by cats. I have feen fome trees with this appearance all over them.

When thefe infects firft appear on the bark, they thould be fcraped off with a wooden knife, and the ftern and branches of the tree well walhed with foap-fuds and urine, applied with a fiff painter's brum. This thould be done in February, before the buds begin to come out, But if the outer bark is perforated, it muft be cut or pared off with a long knife; and if you find any brown fpots in the inner bark, they muft be carefully cut out. This difeafe is one great caufe of the canker, and of the death of the tree. [See PLATE IX. Fig. 3.]

When this difeafe has made its way through both barks, as is often the cafe, the branches on each fide of the tree may be cut clofe to the ftem, if it has an upright one; but if the tree be trained fan-falhion, the beft way is to head it near to the place where it was grafted. I have headed old Pear-trees which were fo dead, except a fmall frip of live bark on one fide, 
fide; that you might rub the bark off them as eafily as off a bundle of faggot-fticks that had been cut upwards of a year; yet thefe trees have thot out frefh branches to the length of feventeen feet in two years, and produced fine fruit the fecond year. Apply the Compofition immediately after heading, or cutting, or paring off the difeafed bark.

A very deftructive fpecies of the coccus tribe has lately done incredible damage to the Apple-trees in the nurferies and gardens in the neighbourhood of London. Some Nurferymen have loft feveral thoufand Apple-trees in one year. Thefe infects attach themfelves to the bark by their fuckers, and, by feeding on the juices of the tree, rob it of its nourithment. Such trees as are infefted with them have a fickly appearance. I am happy, however, in being able to fay, that I have nearly extirpated them from his Majefty's gardens at Kenfington: but, as our neighbours do not pay the fame attention to their trees as we do to ours, the infects frequently emigrate to us; this obliges me to be very attentive to their firft appearance; and, as I take the earlient opportunity of deftroying them, the trees fuffer very little from their depretions.

Thefe infects make their nefts generally where branches have been cut off, or in hollow places, where the canker has eaten holes in the trees. Their firft appearance is like a white down; on touching, or rubbing them, they tinge the fingers of a crimfon colour, like cochineal. If fuffered to remain long on trees, they take wing, like aphides. The method that 1 have followed for thefe ten years to deftroy them is as follows :

I rub the places where their nefts are with an old brum, fuch as painters ufe, till they are all cleaned off; and if the 
part be canker-eaten, I cut it clean out with a knife or chifel $\%$ I then take of foap-fuds and urine equal parts, and with this. I wath the wound and the bark all round it; and witly a bruth apply the Compofition mixed with wood-afhes and the pow-. der of burnt bones, covering the wound all over with it. Afterwards I thake fome of the powder of wood-athes and burnt bones, mixed with an eighth part of unflaked lime finely powdered and fifted, over the hollows, or where knobs: have been cut off.

At the fame time that the trees are cleared of the cocci the caterpillars thould be picked off.

The firft time that 1 obferved the new coccus, which has. done fo much mifchief to the Apple-trees about London, was, in a garden of my own at Chelfea, about the year $1 ; 8.2$ or 3 and, as far as L can learn, they were imported, among fome Apple-trees, by the late Mr. Swinton, of Sloane-Street: Mr. Swinton afterwards removed his nurfery to the King's road near Chelfea College, which now goes by the name of the foreign nurfery.

All the gardens about Chelfea: and Kenfington are now: very much inferted with thefe infects; and I have frequently: feen them in feveral other parts of the kingdom.

Doctor George Fordyce purchafed feveral Apple-trees at the fale of the effects of Mr. De la Tour, Editor of the Courier de l'Europe; all of which were from Mr. Swinton's nurfery, and all infected with thefe infects. The Doctor gave me twelve of thefe trees, which I planted, and very foon cleared them of the coccus.

Meffrs. Lee and Kennedy, Nurferymen at the Vineyard, Hammerfmith, Meffrs. Grimwood and Co. Kenfington, and Meffrs, Gray and Wear at Brompton-Park Nurfery, have 
applied train oil, laid on with a painter's brum, with a view of deftroying thefe infects, but they have not been fuccefsful * Indeed, I by no means approve of applying oil to trees upon any account, as, by thutting up the pores, it is apt to render them bark-bound.

\section{Of Caterpillars.}

Caterpillars are very deftructive to Cabbages, and all the braffica tribe, and frequently make depredations on trees, particularly the Apricot. They thould, therefore, be carefully obferved and picked off. A few years ago, Kenfington gardens were very much infefted with them; but by carefully picking and deftroying them, and all the aurelia that could be come at, very few are now to be feen. During the Winter and Spring, every chryfalis that can be found under the copings of walls, on gates, palings, \&c. Thould be deftroyed. Many may alfo be found about the doors and windows of houfes, under the eaves, and in many other places.

The beit method of preventing trees from being inferted is, to fcrape the ftems with a piece of bone or wood made in the form of a knife, taking care not to bruife the bark; and afterwards to wafh the tree and wall with an equal quantity of foap-fuds and urine mixed.

* Since writing the above I have been informed, that the farmers in Kent likewife ure train oil ; but if they would make a fair trial of urine and foap-fuds, they would find it more effectual, and it would coft nothing but labour : befides, what fa!ls on the borders will make a fine manure. The urine and foap-fuds fhould be faved in tubs in Winter; and, as it will be too ftrong for ufe in Summer, it may be lowered by adding water. This mixture will alfo be found effectual in killing flugs that harbour about the roots of the trees and bottoms of the walls. When it fouks into the ground, the flugs will work their way, and may eafily be killed by throwing a little more of the mixture on them from a watering-pot with a rofe. 
As foon as the leaves are off the trees. in Autumn, they mould be raked and fwept up; then carried to the Melonground and mixed up with other leaves and dung for hot beds; by this means you will get rid of a great number of eggs of infects that are depofited on the underfide of the leaves. Then wath all the ftems of the trees, and all the ends of the buds, taking care not to hurt the buds: in doing this, what falls will deftroy the flugs that take thelter on the offset of the wall and in the borders, before they are dug for planting lettuce, endive, \&x. This wathing fhould be repeated about the beginning of February, which will deftroy any eggs of different infects that may fill remain about the trees. A painter's brufh may be ufed for laying the mixture on the trees, and a foft broom, or a brulh made of the ends of garden matting, for wathing the wall. The matting feems preferable, as, being foft and flexible, it will enter the holes and crevices.

I he mixture that falls on the border and offset of the wall, in this fecond wafling, will deftroy thofe flugs and infects that made their appearance early. The ftems and branches of the trees may be wathed two or three times, or oftener, in the Spring, before the buds begin to fwell; but the branches. must not be rubbed after the trees come into flower; you may, however, fprinkle them over with the mixture from a watering-pot with a rofe juft before the buds begin to open, but by no means after they are open; as it will, by its glutim nous nature, render the bloom liable to be fcorched by the: fun.

I would recommend the above wafhings, \&c. for all trees, Aandards as well as thofe on walls; particularly Apple Cherry, and Plum trees. 
If any Caterpillars thould remain, they will be difcovered by the curling of the leaves; for every curled leaf has one or more caterpillars, or other infects, in it; they fhould there fore be carefully pulled off, and the infects crithed: if negleeted, they will frequently devour every leaf, leaving the' tree quite naked, and of courfe deftroy the fruit for that feafon.

There are fome gregarious forts of caterpillars found in great numbers enclofed in a net, or bag, refembling a frong. cobweb, and fixed to the branches of trees and fhrubs. Thefe nefts fhould be carefully picked off, and the infects crufhed, by which vaft numbers of them will be deftroyed. After you: have cleared the tree as well as you poffibly can, wafh it as above directed, which will deftroy thofe ftragglers that may Aill remain on it.

Obferve, that after the trees come into flower, inftead of wathing them with urine and foap-fuds, they fhould be well watered with clear lime-water, mixed with tobacco-water.

There are feveral fpecies of moths that in the caterpillar ftate are very hurtful to plums and other fruit-trees: it will, therefore, be a great advantage to deftroy them on their firft: appearance.

It would be of great fervice to get acquainted as much as: poffible with the economy and natural hiftory of all thefe infects, as we might thereby be enabled to find out the moft certain method of deftroying them. Were a few of each fort of caterpillars put in a box or cafe, and fed with leaves of fuch trees as they generally live upon, they might be obferved: from time to time until they came to the chryfalis, and from that to the moth or butterfly ftate, and thus a more perfect. knowledge of them might be obtained. 
It would be neceffary to have feparate divifions in the cafe for each different fpecies, and to put fome earth in the bottom. of each divifion, which Thould be moiftened occafionally, as fome of them bury themfelves in their chryfalis ftate, while others adhere to walls, gates, or palings.

Freth leaves thould frequently be put in, and the box or cafe covered with a piece of fine canvas, or gauze, to admit the frem air.

At the fame time that the trees are cleared of the coccus, aphis, or any other infects, the caterpillars thould be carefully looked for and picked off. You will obferve, that they thelter themfelves at the ends of the thoots, in the flowers, and at the bottom of the footftalks of the flowers. There are two or three forts that infert fruit trees, two of a brown and one of a green colour. Four years ago the Apple-trees fuffered very much by a blight; they had all the leaves eaten off, and, of courfe, bore no fruit. I firft had all the caterpillars carefully picked off: I then cut out the cankered wood, and wahed the trees with a mixture of urine, foap-fuds, and frefh cow-dung, fufficient to bring it to the confiftence of paint, laying it on all over the ftems and branches of the trees, particularly where the decayed parts were cut out: after this, the trees recovered in a manner that furprifed every one who faw them; and they ftill continue in a thriving ftate, and bear very fine fruit.

In I 795 I ufed the above method with a great many dwarf Apple-trees; and the effect was fo vifible next feafon, that all who faw them took notice of the great difference between them and the remaining trees, which we had left to nature; the latter bearing no fruit, and their leaves being eaten by the caterpillar, while the former have borne fine clean fruit ever fince, 
The trees, twenty-five in number, which I left to nature, continued in a fickly ftate for three years, neither bearing fruit nor putting forth thoots. After the third year 1 headed them down, fcraping the ftems and cleaning off the infects; they are now recovered, having made as fine wood as the others, and are in a healthy flourining ftate.

Fig. 2. PLATE IX. reprefents different ftates of a kind of moth, whofe caterpillar has for many years done great mifchief among Pear-trees on walls. One wall in particular, in Kenfington gardens, was very much hurt every year, for feveral years fucceffively. I imagined that it had been the effect of lightning, or a blight ; till, on picking off the caterpillars, we found a fmall fort in its cafe, fticking to the leaves, as at a (See the defcription of the Plate.) All the firft leaves were deftroyed by the caterpillars: I was, therefore, rejoiced that I had found out the caufe of their being fo much injured every year, being perforated in many places, and dropping off very early.

\section{The Chermes:}

Chermes is a genus of infects belonging to the order Hemiptera, and of which there are twenty-fix fpecies. They take their fpecific names from the different plants which they frequent; as the chermes graminis, or grafs bug; ; the chermes. ficus, or fig-tree bug, \&cc. The latter is one of the largert of the genus, and is brown above and greenifh beneath. It has four long wings, which are placed in form of an acute roof. The larva, which is of an oblong form, has fix feet, and its motion is flow. When it is attempted to catch the chermes, it makes its efcape rather by leaping than flying, by 
means of its hinder legs, which play like fprings. Some of thefe infects have a manœuvre worthy of notice. Several. fpecies are provided at the extremity of their body with a fmall tharp-pointed implement, but which lies concealed; and this they draw out in order to depofit their eggs, by making a puncture in the plant that fuits them. By this method, the fir-tree chermes produces that enormous fcaly protuberance which is to be found at the fummit of the branches of that tree, and which is formed by the extravafation of the juices occafioned by the punctures. The young larvæ fhelter themfelves in cells contained in the tumour. The directions for deftroying the coccus are applicable to this infect.

\section{The Thrips.}

The Thrips, of which there are eleven fpecies, alfo belongs to the order Hemiptera. This infect is, in general, fo fmall as to be fcarcely difcerned by the naked eye. It is, however, very pernicious to fruit-trees, fometimes attacking the fruit as well as the leaves. To deftroy this infect, follow the directions given for deftroying the coccus.

\section{The Phalena, or Woth.}

There are numerous fpecies of this well-known infeet, and their caterpillars differ greatly as to fize, thape, and colour. All of them; after cafting their flough feveral times, fpin their cod, in which they are transformed to chryfalids. They are frequently found in this ftate, rolled up in the leaves of fruit- 
trees; particularly thofe of Pears, Plums, and Cherries. Thefe leaves muft be carefully picked off, and the infects crufhed: the trees muft then be wathed with clear lime-water mixed with tobacco-water. This wathing would be found ufeful when the infect is in its larva ftate, after picking off and crufhing as many of the caterpillars as poffible. See Caterpillars. (Page 267.)

\section{Splinx or Hawk-Moth.}

There are 165 fpecies of this genus, ten of which are found in Great Britain and Ireland.

The name of Sphinx is given to this genus on account of the ingular attitudes of their caterpillars, who apply the hinder part of their body to a branch of a tree, and hold the reft of it erect, like the fabulous fphinx. Moft of them fpin their cod under ground. The fphinges appear either early in the morning, or after funfet, and fly heavily and nuggilhly, often emitting a kind of found. Many of the caterpillars are green and fmooth, fome brown, or yellow, and others are fpotted, or have belts. The fphinx may be deftroyed by the fame method as the Phalæna.

\section{The Prialana Bombyr Nenfira.}

The Phalæna Neuftria, or Lackey Moth, lays its eggs in rings round the branches of fruit-trecs, exhibiting the appearance of a necklace. Thefe being very hard, and adhering clofe to the bark, mut be cut off with a tharp knife, taking 
care to wound the bark as little as poffible; and wherever the knife enters, it will be neceffary to rub in a little of the Compolition.

\section{The Papilio.}

The Papilio, or Butterfly, belongs to the order Lepidoptera. There are a great many fpecies of this genus, generally diftinguifhed by the colour of their wings: The more common forts, with their caterpillars, are fo well known as to render a defcription of them unneceffary. The caterpillars and chryfalids muft be carefully picked off, and the trees well watered with clear lime-water and tobacco-water mixed.

\section{The Cicado.}

The Cicada, Frog-hopper, or Flea-Locuft, is a genus of infects belonging to the order Hemiptera. The larvæ of feveral of this genus evacuate great quantities of a frothy matter upon the branches and leaves of plants or trees, in the midft of which they conftantly refide, probably for fhelter againt other animals; perhaps, alfo, the moifure of this foam may ferve to fecure them from the fultry rays of the fun.

As the froth emitted by thefe infects is very unfightly, and as they are alfo hurtful to trees, by eating the leaves, they. mould be deftroyed by rubbing off the larva with the hand, and afterwards watering the tree plentifully with foft water. 
of Earwigs.

Earwigs are very deftruetive to fruit, particularly l'caches. The method that I would recommend for deftroying them, and which I have long purfued with fuccefs, is as follows.

Take old bean-ftalks, cut them about rine inches long, tie them up, in fmall bundles, with fome pack-thread, or with Imall yellow willows; and hang them on nails againf the wall, at different parts of the trees. The firt thing you do in the morning, being provided with a board about eighteen inches fquare, and a fmall wooden trowel, take down the bundles of bean-ftalks, one by one, ftrike them againf the board, and with your trowel kill the earwigs as they fall out. of the ftalks. If you follow this up every morning (or every other morning), you will be able to keep them under.

The foregoing method will anfwer for any fort of trees infefted with earwigs. In fome years $I$ have feen a great part of the fruit, efpecially the fmooth-1kinned forts, deftroyed by thefe infects and a fmall green caterpillar; and in a fcarce year of fruit, the leaves of Peaches are frequently deftroyed by them.

The fireds taken from trees that have been unnailed in Autumn, thould be foaked in boiling-hot foap-fuds for three or four days, previous to their being ufed again; this will kill the eggs of earwigs and other infeets that may be depo. fited on them.

$$
\text { Of the Ant. }
$$

The Ant is very deftructive to fruit, efpecially the Peach when ripe: you will frequently fee thefe infects travelling $\mathrm{N} \mathrm{N}_{2}$ 
all over the trees, and fometimes the fruit will be filled with. them. The beft method that I have found to deftroy them: is, to get a lharp-pointed wooden ftake, or an iron crow, if: the ground be hard, and with it bore a hole clofe to the fide of the wall, and as deep as the ground will permit. By firring the earth, you will fet the ants in motion: then work your ftake or crow round the fides of the hole, making them as fmooth as you can; the ants will come to the mouth of the hole and tumble in, and, by the thape of the hole and fmoothnefs of its fides, will be prevented from climbing up again. When you fee a great many in the bottom of the hole, pour in fome water from a watering-pot; and thus you may drown thoufands of them. It is to be obferved, that there muft be feveral holes made, according to the length of the wall.

This is an eafy and fimple way to get rid of ants. Some: are of opinion that they do good by eating the aphides from off the trees; but I have always thought that they do much more hurt than good:

You may likewife deftroy many of them by mixing quick-. lime with foot, and laying it along their roads where you fee them thickeft; but where you can come at their nefts, the beft ivay is to put a piece of quick lime into it, and pour as much water over the lime as will flake it, the heat of which will deftroy them: when you have poured in the water, cover the lime with a turf or a little earth, which will render it more effectual, by confining the heat. You may flake the lime with a mixture of urine and foap-fuds, which will render it ftill more effectual.

If a little of the powder of ftavesacre be laid on the ground round the ftem of a tree, it will prevent ants from afcending it: 


\section{Slugso:}

Thefe infects are frequently found harbouring about the foundations of walls, and about the roots of Peafe, Lettuce, \&c. They may be picked off and killed, by putting them: into a pot in which is a little fine unflaked lime; or the ground where they are fhould be well watered with foap-fuds and urine, mixed with tobacco-water. When they are numerous on the furface of the ground, which frequently happens after ráin, or in a dewy morning, fine unflaked lime thrown over the borders, \&c. will deftroy them. . But I prefer the above mixture, which, if the ground be well watered with it, will bring them up out of their holes, when they very foon die: it will alfo deftroy their eggs, which theyalways depofit in the earth.

\section{Snaits.}

Snails, during the winter, gather themfelves together in clufters; and in that feafon are frequently found in great. numbers behind wall-trees, and in holes of the walls. They muft be carefully picked off and crufhed, which is the only effectual way of getting rid of them. If any thould efcape, they thould be deftroyed as they make their appearance in the fpring. As they alfo depofit their eggs in the ground, the borders thould be well watered, as directed for flugs. 


\section{Of Wajps and Flics.}

As foon as the wafp and large fleth fly (which are very deftruetive to ail kinds of fruit, particularly Grapes) make their appearance, get ready feveral bottles, or phials; then mix up grounds of wine, or beer, with fweepings of fugar, honey, or grounds of treacle, and with this mixture fill the bottles half, or three quarters full, then place fome of them. at the bottom of the wall and hang a fufficient number up by. a piece of yellow willow or packthread on the nails againft the walls in different places, obferving to empty them frequently, as they fill with flies and wafps; firft pour the liquor into an empty bottle, and then thake out the dead infeets; crufhing them with your foot, that none of them may. revive: then pour back the liquor into the bottles and phials, as at firft. In this manner you may deftroy a great many before the fruit becomes ripe. If you begin to hang up the bottles as foon as you fee the fly, which comes much earlier than the wafp, you will be able to deftroy great numbers of them, and will have the bottles ready for the wafps. when they make their appearance. The fly will be found as deftruetive as the wafp to (irapes.

When the weather is hot, and the wafps are numerous, if they do not enter the bottles faft enough (which will happen when the fruit is very ripe), take a little oil in a cup, and with a: feather dipped in it touch their backs, and they will inftantly drop down: on obferving, you will find them turned black. and green by the effects of the oil *. It is amazing what 
numbers a diligent perfon can deftroy in this way in a day. Oil has the fame effeet on flies; but it is very difficult to touch them with it as they are fo quick in their motions.

\section{Of Birds,}

When fruit begins to ripen, Birds will attack it. The beft preventive in this cafe is, to cover the trees with nets, or buntine, a fort of cloth of which thips' colours are made. Thefe will admit a free circulation of air to the fruit, and will foon dry after rain: they will alfo be a good covering for the trees in Spring, in cold, wet, or fnowy weather.

\section{Rats and Mice.}

Thefe vermine do a great deal of mifchief in gardens, in Theds, and other places, where they frequently deftioy great quantities of Beans, Peafe, and other feeds; it is, therefore, the intereft of every gardener to kill as many of them as poffible.

There are different ways of deftroying them, by traps, and by poifon; but I would advife never to ufe arfenic, or corrofive fublimate, for that purpofe, except under particular circumftances, as they are deadly poifon: nux vomica will generally anfwer the end as well, without the danger. In cafe of being accidentally tafted by children or others, it will be attended with no worfe confequence than leaving a difagreeable bitter taite in the mouth; unlefs, indeed, a confiderable quantity of it be taken, which would, no doube, prove fatal; 
fatal *; as it is poffeffed of a ftrong narcotic quality, and is: found a certain poifon for dogs and cats, as well as for rats and mice. All domeftic animals fhould, therefore, be kept. from the places where the poifon is laid. A very good way to prevent accidents is, to enclofe the traps in cafes, having holes in the ends of them large enough to admit the rats, but fmall enough to exclude dogs, cats, \&c.

\section{A Bait for Rat-Traps.}

Take a pound of good flour, three ounces of treacle, and fix drops of the oil of carraways; put them all in a difh, and rub them well together till they are properly mixed; then add a pound of crumb of bread.

Set the traps, baited with fome of the foregoing mixture, as near their haunts as poffible; but, for two or three days, fo as not to fall or ftrike on the rats going in, and let them have free liberty to go in and out at pleafure; this will make them fearlefs. Lay fome of the bait at the rat-holes, and fcatter a little of it quite up to the traps, and fo on to the bridge of each trap, where you may lay a handful. It may alfo be proper to fcent the traps with the following mixture, for the purpofe of enticing the rats into them.

Take twenty drops of oil of rhodium, fix or feven grains of mufk, and half an ounce of oil of annifeed; put them in a fmall phial, and thake it well before ufing :-then dip a bit of twifted paper, or rag in the mixture, and rub each end of the trap with it, if a box-trap, and put two or three drops on the

* It has been taken in dores of from five to ten grains, twice a day, in intermittents and dyfenteries.

bridge, 
bridge, leaving the paper or rag in the trap. Of whatever kind the trap is, it thould be fcented : once in a twelvemonth will be fufficient. Then throw fome chaff, mixed with a little wheat, about the bottom of the trap, in order to deceive the rats; for they are very fagacious, and will not enter a fufpicious place. This will be neceffary to be done only at the firft time of fetting the traps; for after fome rats have been caught and have watered and dunged in them, rats will enter boldly when they find others have been there before them: do not, therefore, wath or clean out the trap, as fome people do before they fet it again; but let the dung and urine: remain in it. Keep the places where the traps are fet as private as poffible; and when you fet them for catching, mix no bread with the bait, as the rats will in that cafe be apt to carry it away.

When you find the holes quiet, and that no rats ufe them, ftop them up with the following compofition. Take a pint of common tar, half an ounce of pearl-athes, an ounce of oil of vitriol, and a good handful of common falt, mix them all well together, in an old pan or pot. Take fome pieces of paper, and lay fome of the above mixture very thick on them, then ftop the holes well up with them, and build up the mouth of the holes with brick, or ftone, and mortar: if this be properly done, rats will no more approach thefe, while. either fmell or tafte remains in the compofition.

\section{To kill Rats in Places where you cannot fet Traps.}

Take a quart of the bait already defcribed, then rafp into it three nuts of nux vomica, and add a quarter of a pound of 
crumb of bread, if there was none before; mix them all well together, and lay it into the mouth of their holes, and in different places where they frequent; but firit give them of the bait without the nux vomica for three or four fucceeding nights; and when they find it agrees with them, they will eat that mixed with the nut with greedinefs.

Rats are frequently very troublefome in thores and drains. In fuch cafe, arfenic may be ufed with fuccefs, as follows: take fome dead rats, and having put fome white arfenic, finely powdered, into an old pepper-box thake a quantity of it on the foreparts of the dead rats, and put them down the holes, or avenues by the fides of the fhores, at which they come in; this puts a ftop to the live ones coming any further; for when they perceive the arfenic they. will retire immediately; whereas if you were to put down the dead rats without the arfenic, the live ones would eat them.

What has been faid relates chiefly to rats; we thall now give fome directions for deftroying mice.

Take a quart of the bait prefcribed for rats before there is any bread mixed with it; then take four nuts of nux vomica, and rafp them very fine, otherwife the mice will pick out the food from it, on account of its bitter tafte; rub them well together; lay fome of it on a piece of paper, or, if without doors, on a piece of tile, removing all other food from the place, and it will kill all that eat of it. What is not eaten, take away in the morning, and replace it at night. If this be in a garden, thelter it with boards, or tiles, that it may not get wet.

I would recommend fetting fourth-figure traps in gardens: thefe are fo well known to gardeners, that they need no defcription. They may be baited with garden Beans. 
Traps are alfo made by ftringing garden beans on a piece of fine pack-thread, as you would ftring beads, then driving in two fmall ftakes at the breadth of a brick from each other, and fetting up a brick, or ftone, or a board with a weight on it, inclining to an angle of about forty-five degrees; then tie the ftring, with the beans on it, round the brick and ftakes, to fupport the brick in its inclining pofition, taking care to place all the beans on the under fide of the brick. The mice in eating the Beans will alfo cut the packthread, and fo difengage the brick, or ftone, which falling on them kills them.

There is nothing new in the foregoing method; but, as field-mice will feldom enter a clofe trap, I thought proper to mention it.

As mice are frequently carried into gardens with ftraw, or litter, and are there extremely hurtful, deftroying Beans and Peafe in Spring, as alfo Lettuces, Melons, and Cucumbers in frames, it is neceffary to take fome pains to deftroy them. 


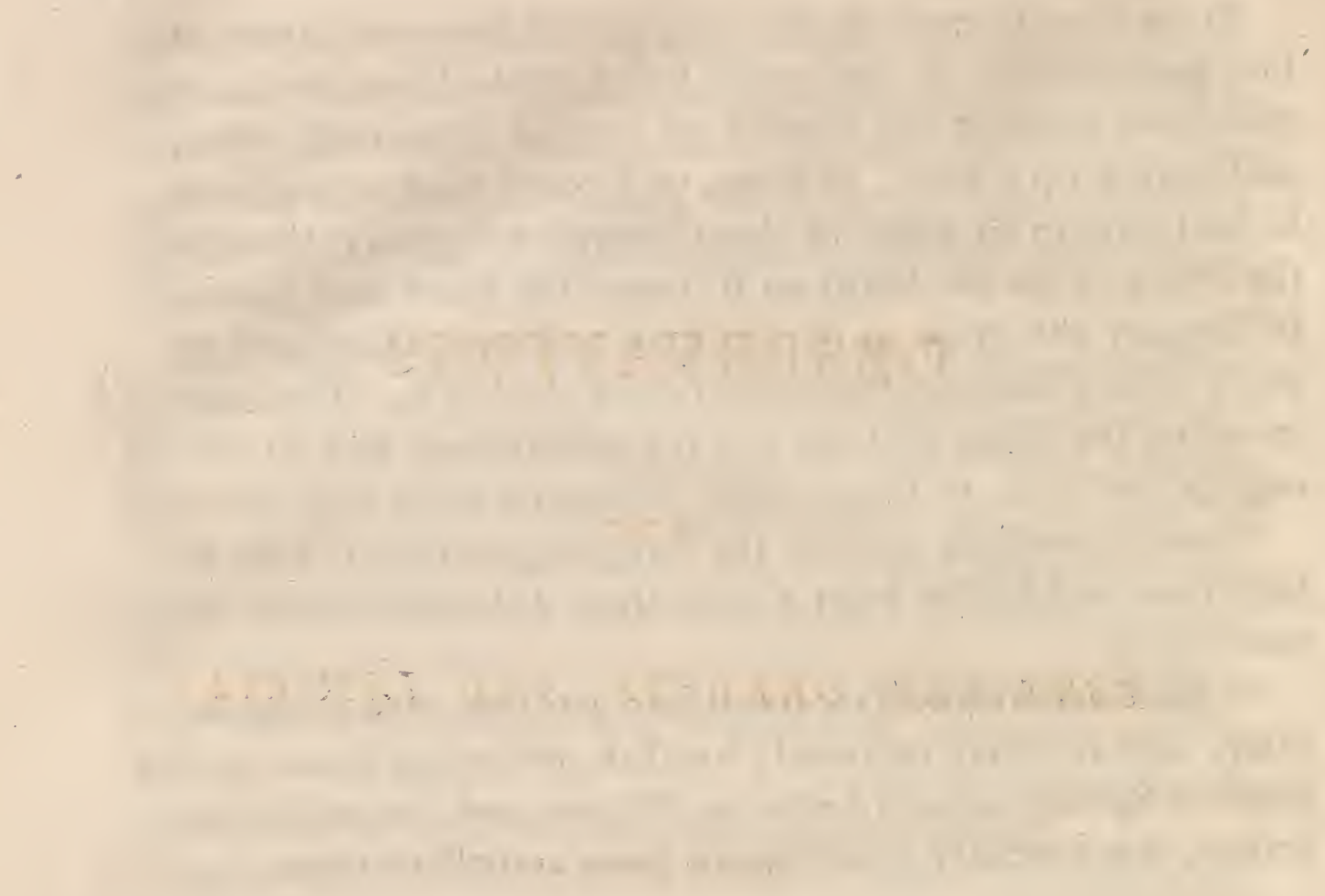

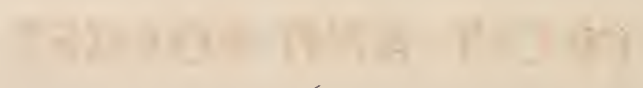




\section{OBSERVATIONS}

ON THE

DISEASES, DEFECTS, AND INJURIES,

JN ALL KINDS OF

FRUIT AND FOREST TREES. 


\section{BVOITHVRดคด}

$\ldots+\cdots j$

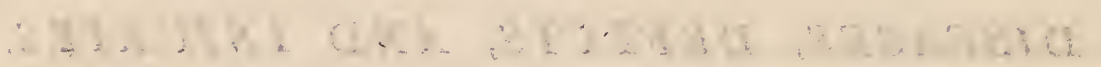

is $:=i \ldots$,

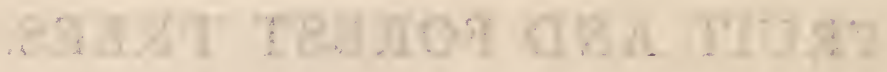




\section{INTRODUCTION.}

$T$ redounds very much to the general honour of the Britifh nation, as well as to the particular credit of the Society for the Encouragement of Arts, Manufactures, and Commerce, and feveral other affociations for the advancement of Agriculture, \&c. that the face of the country has, in the courfe of the prefent century, received fo much improvement, and fuch added beauty.

The premiums and honorary marks of diftinction held forth by thefe focieties have excited a fpirit of emulation, or fuggefted a fpirit of improvement, among perfons of every rank of life, which have been productive of many difcoveries of no common benefit in their prefent effects, and of great promife from their future confequences, to the community at large.

But, notwithftanding the ftrides which modern agriculture has made towards perfection in many points, there is one particular and very interefting branch of this fcience which improvement has not yet embraced, viz. the growth of timber, and the culture and management of plantations both of fruit and foreft trees.

The profeffion of a gardener has been the employment of my life; and, during a long fucceffion of years, it has been an object of my particular ftudy to invertigate and difcover the 
latent caufes of thofe various defeets and difeafes to which all kinds of trees are more or lefs fubject, and the injuries refulting from them, by obftucting the fertility of fruit-trees, and diminifhing the quantity, as well as quality, of timber in foreft-trees.

Having acquired a competent knowledge of the evil in all its appearances and effects, my attention was directed toward the difcovery of fuch a remedy as might not only counteract the progrefs of thefe difeafes in fruit and forett trees, but alfo afford nature fuch powerful affiftance, that the might be enabled to renovate, as it were, fertility in the one, and found timber in the other. Of my fuccefs in thefe endeavours to promote the general advantage of this country in a matter fo connected with its beft interefts, I have that clear conviction which, I truft, will be hereafter communicated to every part of the kingdom where the application of my experience Thall be made and profecuted.

The inquifitive fpirit which accompanied my profeffional purfuits, with the natural defire of improving my private practice in the management of the various kinds of trees under my care, led me by degrees to this difcovery. The idea, however, of making it public never occurred to me, till the many trials and experiments that I had repeatedly made, both on fruit and foreft trees, in the Royal gardens at Kenfington, had attracted the notice of many perfons of high rank, as well as philofophical eminence, and prompted them to favour it with a particular examination. Their inveltigation of my procefs and method of curing the defects and injuries which, from various caufes, thofe trees had fuftained, by producing conviction in their minds, gave the moft flattering encouragement to me. Indeed, the application of the re- 
medy had been attended with fuch uninterrupted fuccefs, that its falutary and certain effects were evident to every one who favoured it with an attentive obfervation. Many, who vifited me with the moft decided opinions againft the fuccefsful application of any remedy for trees in a very advanced ftate of decay, did not hefitate, on an invertigation of the fubject, to acknowledge that their prejudices were not only removed, but that their judgments were perfectly convinced of the powerful efficacy of the difcovery, and the very great advantages which, both in an individual and a national view, might be derived from it.

Among the more early enquirers, were the commiffioners appointed by parliament to examine into the ftate of the woods, forefts, and land revenues of the crown; who, in the courfe of their furveys, had perceived a great number of trees in the Royal forefts to be materially injured; and their anxiety to prevent the lofs or further damage of fo much valuable timber induced them to honour me with a letter * concerning the effects of injuries done to oak-trees, and the means of preventing or curing defects in timber from various caufes therein ftated.

In reply to this inquiry of the Commiffioners, I did myfelf the honour of addreffing them two fucceffive letters $\uparrow$.

Shortly after the date of thefe letters, the Commiffioners favoured me with a vifit at Kenfington, to examine the procefs and mode of cure which I had adopted, as well as the effects which my remedy had produced on trees of various kinds and ages to which it had been applied. Thofe gentlemen feemed, in a moft particular manner, to intereft them-

* See No. I. of the Appendix. + See Nos. II. and III. of the Appendix. 
felves in afcertaining the utility and benefit that might arife from the application of it to many thoufand valuable trees in his Majefty's woods and forefts, which had received injuries of fuch a kind as, if left to the unaffifted efforts of nature, would occafion a very confiderable diminution. in the value and the quality of the timber, and might even terminate in their entire ruin *.

This very attentive and minute examination of the feveral objects of their inquiry being followed by the cleareft conviction of the great public utility which would refult from a general application of the remedy, the Commiffioners were pleafed to make a reprefentation of it to the Lords of his Majefty's Treafury, under whofe fanction it was fubmitted to the confideration of the Houfe of Commons by Mr. Rofe, on the 24 th of July 1789 ; and, on his motion, an humble Addrefs was prefented by that honourable Houfe to his Majefty on the fubject $\downarrow$.

In confequence of this Addrefs, a Committee of Members of both Houfes of Parliament undertook, at the inftance of the Lords of the Treafury, to invertigate the efficacy of my Compofition; for which purpofe, they moft attentively examined the ftate, condition, and progrefs of cure, of the decayed and

* Mr. Nichol, of Redbridge, Hants, Purveyor for Portfmouth Dock, informed me, that the average of the damaged timber brought to that place was never lefs than one fourth of the total quantity of timber brought in annually; and not: unfrequently it: amounted to a third. If, however, the trees that have received any injuries were prepared, and the Compofition applied as directed in this Treatife, the cavities, or wounds, sould be filled up with new and found wood. And if recent wounds, occafioned by lopping, or breaking off branches, were immediately dreffed in a proper manner with the Compofition, the tree would fuftain no injury; as the wounds would be healed and. covered over with new and found bark in a fhort fpace of time; fo that there would not be found a foot of damaged timber.

+ See No. IV. of the Appendix. 
injured trees in Kenfington gardens, to which it had been applied, in experiments of various kinds, for upwards of feven preceding years; and, after having, by a very full enquiry, frict inveftigation, and the moft minute attention, fatisfied their minds in every particular, they reported to the Lords of the Treafury the refult of their examination, expreffing their unanimous opinion and conviction, that "The Compofition was a difcovery which might be rendered highly beneficial both to individuals and the public." That Report; and alfo a Letter previounly written to the Committee by the Commiffioners of the Land Revenue, of which I have been favoured with copies, are, for the further information of the Public, inferted in the Appendix *

Having been thus honoured by the unanimous approbation of perfons fo refpectable for their rank, character, and knowledge, I proceeded to exert myfelf in making various additional trials and experiments, to enable me to give farther proofs of the efficacy of my Compofition, in reftoring the powers of vegetation to trees fo far decayed as to be of no value as timber, but which, from their fituation as a $1 \mathrm{kreer}$, or as compofing part of a general uniform appearance in the Royal gardens, it became a defirable object to preferve. Nor were my endeavours lefs fuccefsful in this fubordinate experiment, than they had been in thofe which were directed by circumftances of fuperior intereft; for I had the very great fatisfaction to find, that, in confequence of my treatment of trees in that ftate of decay which has jut been fpecified, a few years' growth has filled up unfightly chafms, and reftored that uniformity to their local pofition, which young plants fet in their places would not have accomplifhed in a long courfe of fuccellive years. 
The Report of the Committee having been laid before his Majefty, in confideration of the great utility and advantage which muft arife to the country at large from the ufe of this Compofition, his Majefty was moft gracioufly pleafed to order a reward to be given to the author, for making known to the public the materials of which it is compofed, with the method of preparing it, as well as the mode of its application; and, in order to diffufe the benefits of this difcovery throughout the kingdom, an advertifement ${ }^{*}$ has been inferted in the London Gazette, and in mort of the town and country newfpapers.

The very great importance to this country of fecuring a continued fucceffion of good, healthy, and well-growing foreft-trees, producing found, unblemifhed timber, for fupplying the various wants of the public, muft be evident to every man's reflection; nor need it be obferved, that numberlefs large trees, in the woods, parks, and forefts, of this kingdom, are, from various caufes, rendered unfit for ufe, and the timber fo much damaged as to occafion a confiderable diminution in its value. This evil arifes, in fome inftances, from unfkilful management, and in others from external accidents; among which are, the ruinous effects of hurricanes and high winds, when the trees are generally left, in their wounded and disfigured ftate, to the accelerated operations of inevitable decay. It alfo not unfrequently happens, that the heirs of large eftates, on coming to the poffeffion of them, order great numbers of trees to be promifcuoufly felled, before they have attained a ftate of maturity, without paying the leaft attention to provide a fucceffion of young trees to fupply their place; by fuch inexcufable negligence de-

* See No. VI. of the Appendix.

feating 
feating the ends propofed by the provident care and wifdom of their anceftors, depriving the public of a valuable fource of timber, either for domeftic purpofes or national ufe, and reducing their country to a dependance on foreign produce for fupplying the demands of her fleets and manufactures.

I hall efteem myfelf moft happy, if, in giving this tribute of information to the general ftock of public improvement, I fhould promote an influence that may excite noblemen and gentlemen, and proprietors of land of every denomination throughout the kingdom, to be actively folicitous in planting and preferving oak-timber, the native growth of their country; that Great Britain may never be under the dangerous as well as difagreeable neceffity of trufting the fafety of her feamen to the inferior texture and lefs durable quality of foreign growths; while the hardy oaks of England, which for ages paft have been confidered as affording the beft timber in the world for this building, and may have been faid to have brought home victory and commerce from every part of the globe, are no longer fuffered to diminifh, as they have done of late, to the manifent detriment and difhonour of our country.

Such an evil (and it is of no common magnitude) proceeds from the negligence and inattention of the landed men, who, from a firit of patriotic ambition, as well as private interent, fhould pay a very vigilant attention to the maintaining of a fucceffion of healthy, well-growing timber, for the fervice of their country, nor any longer fuffer the internal refources of the kingdom to fail in furnifhing materials for that great national object, the fupport of the Britifh navy; as well as for the many various demands of domeftic utility. By making fuch a provifion for the public wants, they will add 
to their own immediate wealth, as well as to the fortunes of thofe who come after them: and, while I exprefs my wirhes that fuch general good defigns may be put in univerfal practice, I may exprefs my belief, that the difcovery which I have made, and which is now divulged to the public *, will facilitate the means of profecuting them, to the effential advantage of the Britilh Empire.

General Obfervations on the Difeafes, Defects, and Injuries, of all Kinds of Fruit and Foreft Trees.

In the courfe of more than thirty years practice in cultivating, pruning, and keeping of garden fruit-trees, I have obferved, that, from natural caufes, accidents, and unfkilful management, they were fubject to injuries of different kinds, which always diminifhed their fertility, and frequently rendered them wholly unproductive.

All trees that bear ftone-fruit are liable to emit a gum, which, by producing a canker, proves fatal to the health and vegetation of the tree. Mont foreft-trees are alfo liable to what is called a bleeding, which proceeds from any injuries that obftruct the circulation of the juices. Of thofe which fuffer from bad management on accidents, fome are injured by unfkilful pruning, and lopping at improper feafons of the year; and others by the violence of high winds, having boughs or limbs torn from their bodies; which being left in that ftate, expofed to all the inclemency of hard frofts, are often cracked or rent in the wood; or from heavy and foaking rains, the wounds imbibe fo large a quantity of wet and moifture, as, by caufing a fermentation with the natural

* See Nos. VI, and VII. of the Appendix.

juices, 
juices, brings on difeafe, and in time deftroys the health and vegetation of the tree. Thefe, among other caufes, tend to produce decay and barrennefs in fruit-trees, as well as defects in timber, to the great lofs of the public in general, as well as effential injury to the individual proprietor.

To remove thefe evils, and to prevent the ill confequences arifing from the caufes already defcribed, I fubmit to the experience of the public a remedy difcovered by myfelf, which has been applied with never-failing fuccefs to all kinds of fruit-trees, and has not only prevented further decay, but actually reftored vegetation and increafed fruitfulnefs, even in fuch as were apparently barren and decayed. It has produced alfo a fimilar effect on foreft-trees, by reftoring: them to foundnefs of timber and healthful vegetation, and covering, as it were, vifible nakednefs and increafing decay, with frefh and vigorous foliage.

This remedy is a Compofition formerly applied in the manner of a plafter, but now in a liquid ftate, and laid over the wounded or injured part of the tree with a painter's brufh: it is of a foft and healing nature; poffeffes an abforbent and adhefive quality; and, by refifting the force of wanhing rains, the contraction of nipping frofts, and the effects of a warm fun or drying winds, excludes the pernicious influence of a changeable atmofphere.

The difcovery of it is the refult of much reflection and ftudy during a long courfe of years, and of a great variety of experiments, made, at a very confiderable expence, to afcertain the efficacious powers of the application. Nor thall I hefitate a moment to declare my firm belief, that wherever it ihall be properly. applied by the proprietors of gardens, or chards, and woods, it will be productive of all the advantage 
that can be derived from reftoring as well as preferving vigour and fertility in all kinds of fruit-trees; as alfo from preventing decay, and promoting health and found timber, in every fpecies of foreft-trees: and how great that advantage may be, it is in the capacity of every one to determine.

\section{On the Management of Forest-Trees.}

The received opinion and common practice of moft profeffional men has been, to prune or top their trees, from the month of October, when the juices have been exhaufted by the Summer foliage, autumnal fruit, and general nourifhment of the body of the tree, until the month of March, when the fap or juices, re-invigorated by nature during the Winter's repofe, begin to re-afcend and perform the annual function of cloathing it with frefh foliage, bloffoms, and fruit. The reafon of this practice is, that, the fap being fallen at that feafon of the year, it has been confidered as the molt proper period to lop off all fuperfluous growths; and the efforts of nature to heal the wounds thus neceffarily given, (before the rifing of the fap in the following Spring) have been judged beft for the fafety and health of the tree. The danger of performing this fervice when the juices are in a more vigorous flow, as in the months of May, June, and July, has been dreaded, from a fear of its occafioning a wafte of the nutritive juices, difcharging themfelves through the wound, to the impoverifhment and injury, if not the ruin, of the tree.

The pruning of fruit-trees and the lopping off large branches from foreft-trees during the Winter feafon, has alfo been frequently attended with great hurt and impediment to their 
health and vegetation; the wounds being expofed to all the rigours of an inclement feafon, and thereby contracting thofe difeafes which contain the principles of decay. Hence it is, that fuch numbers of foreft-trees are continually injured in their value for public ufes, either by unfkilful management or purpofed depredation, or by the violence of boifterous winds, when; their limbs and branches being torn off, the trees are left in that unprotected ftate to imbibe the feeds of decay and rottennefs, which will in time pervade their very heart, and render them unfit for any of thofe valuable purpofes for which nature, by their frame and texture, appears to have defigned them.

It may alfo be obferved, that where branches have been cut off from the body of the tree, even at the diftance of two or more feet from the trunk, with a view to prevent injury to the timber, even that method has not been found effectual to fave the tree from very material detriment; as the remaining ftem of the branch fo cut away, dying foon after, becomes a ready conduit for conveying pernicious moifture and difeafe to that part of the tree with which it is connected; and fo on, in time, to the whole.

The practice of others, in lopping their trees clofe to the trunk, and dreffing the part fmooth and even, has lefs objections than the former; neverthelefs, even according to this method, the tree is liable to injury. The effort of nature to heal the wounds thus given difcovers itfelf by encircling the wound with a kind of callus, or lip, which, increafing in fize, and fwelling out from the annual flow of the juices, forms a hollow or cavity of the central part, where the rain or fnow is very apt to lodge; and, penctrating between the bark and. the wood, dried and cracked by a hard froft or a warm fun,

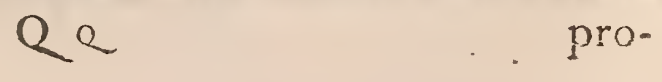


promotes that fermentation with the natural juices, which is the certain fource of difeafe and decay.

Young, healthful, and vigorous trees, when they have been injured by being wantonly cut through the bark, or from other caufes, will fometimes recover themfelves, and, to all outward appearance, be reftored to their original foundnefs; but when cut into planks and boards, internal blemifhes and faults are difcovered in them, which appear to have been occafioned by the early injuries which the tree had received; the texture of the wood not uniting where the wound was originally given; though, from the youthful vigour of nature, the bărk has clofed, and an external cure been evidently performed.

As a moft efficacious remedy to prevent the evils that I have defcribed, with all their deftructive confequences, and to reftore found timber where the fymptoms of decay are already apparent, I confidently recommend the ufe of my Compofition, which, being applied in a proper manner to the wounded or injured part, will infallibly prevent the bleeding of trees, or the oozing of juices through the wounds of limbs. or branches that have been cut off in the middle of Summer, when they are in their higheft vigour, and moft rapid flow of vegetation: by which means, any wafteful difcharge of the juices is prevented, and they are duly confined to their natural operations of giving nourihment, growth, and fertility, to their refpective bodies.

By employing the propofed remedy, trees of all kind's, whether in gardens or orchards, in parks or forefts, may with. greater fafety and advantage be pruned or lopped in the Spring, or early in the Summer, than in the Winter feafon: as the Compofition, when properly applied, repels the flow of 
the juices through the wound, caufes a more adive vegetation, and affits nature more powerfully in healing the wound at the time the fap is in full vigour, than when it is on the decline, as in Autumn and Winter.

It is alfo neceffary to remark, that both fruit and foren trees (particularly thofe which grow in the thade) are very liable to be affected with diforders proceeding from the growth of liver-wort, and various kinds of mofs, that adhere to the outer bark of the tree, and frequently gain a confiderable thicknefs, that not only prevents the natural flow of the juices, but caufes a ftagnation in the circulation, and brings on decay; which, after deftroying the outer bark, penetrates, by degrees, deeper into the wood. Where this circumftance is obferved, care thould be taken to clear the whole bark of the tree from thefe growths; and where it is infected, to fcrape or pare it away. When the body of the tree is thus cleanfed from infection, the Compofition fhould be applied, in a liquid ftate, to the parts fo cleaned, to clofe the pores of the wood; when the tree will foon acquire a frefh bark, with improved health and vegetation. I am confirmed in thefe opinions by the many experiments and various trials that I have made to afcertain, by the moft pofitive proofs, the properties of this Compofition, before I ventured to offer it to the public attention. Indeed, every year's experience has increafed my conviction of its general utility, when properly applied to the purpofes for which it is recommended. To give a more complete illuftration of its virtues, and to place the advantages arifing from it in a fronger light, I thall beg leave to ftate a few of the very numerous experiments that I have made on the foreft trees in his Majefty's Gardens at Kenfing-

$$
\text { Q } 2
$$


ton, where the falutary effects of the Compofition are evident to every attentive obferver.

The firft trials of its efficacy were made on fome very large and antient elms, many of which were in a moft decayed ftate, having all their upper parts broken, by high winds, from their trunks, which were withal fo hollow and decayed, that a fmall portion alone of the bark remained alive and found. Of. thefe trees I cut away at firft a part only of the rotten fuff from the hollow of the tree, and then applied the plafter to the place where the operation had been performed, by way of an internal coat of the Compofition. In a fhort time, however, the efforts of nature, with a renovated flow of the juices, were clearly difcernible in their formation of new wood, uniting with, and fwelling, as it were, from the old, till it became a ftrong fupport to that part of the tree where the Compofition had been applied. I then cut away more of the rotten wood from the infide, applying the plafter in the fame manner, with the fame good effects, and continued to ufe the knife in proportion to the acquifition of new wood; fo that, from the tops of thefe decayed and naked trunks, ftems have actually grown of above thirty feet in height, in the courfe of fix or feven years from the firft application of the Compofition; an incontrovertible proof of its good effects. in reftoring decayed vegetation.

Many other elm trees, which had received hurts from bruifes and other caufes, and where difeafe and decay were already evident, after cutting away all the infected part, and duly applying the plafter, were fo completely healed, that the outline of the wound is fcarcely difcernible on the bark, and the new worod is as perfectly united to the old, as if it had: been originally formed with the tree. 
Of oak-trees alfo, which had received very confiderable damage from various accidents, as blows, bruifes, and cutting of deep letters, the rubbing off of the bark by the ends of rollers, or wheels of carts, and mutilated branches, a perfect cure has been made and found timber produced. The acidity, or corrofive quality, of the juice of oak-trees, when obftructed in their circulation from any of the caufes already mentioned, and fermenting with the wet and moiture imbibed by the wounds from the atmofphere, will bring on difeafe, and promote decay: for, notwithftanding the hard texture of the oak, when once the principles of decay begin to operate, the acrimonious juices feed the difeafe, and accelerate its progrefs, as much, perhaps, as in trees of a fofter quality and texture; but when the difeafed or injured part is entirely cut away to the frefh found wood, and the Compofition properly laid on, as perfect a cure has been made as I have already related in the recovery of elm trees. Indeed, when I reflect that the oak has been the boaft of our early ancentors, and the means, under the bleffing of God, of affording protection and fafety, as well as accumulating honour and wealth, to the nation, what language can fufficiently deplore that want of public fpirit, and that ftrange inattention to the prefervation and increafe of this ftaple tree, which fuffers fuch numbers of ftately oaks to go to decay; in which difgraceful ftate they remain to upbraid their poffeffors, as fues to the commerce and naval glory of the kingdom !

Various experiments have alfo been made on other forefttrees, as ath, limes, chefnuts, and fycamores, that had received the feveral injuries to which they are expofed; as well as many of the refinous kinds, fuch as the cedar of Lebanon, and others of the pine tribe; in all of which $I$ have experienced 
rienced a degree of fuccefs that exceeded my moft fanguine expectations.

As I feel a ftrong folicitude to render my experiments of the mort extenfive advantage to the community, and in particular to the proprietors of landed eftates throughout the kingdom, I beg leave to recommend to their particular attention, that all foreft trees, whether felled with a faw or an axe, may be cut near to the ground; at the fame time carefully preferving the ftump and roots from any further injury. The furface fhould then be made quite fmooth when the Compofition may be fpread over the whole furface according to the directions already given. It thould, however, be obferved, that the Compofition, when employed for this particular purpole, fhould have an equal quantity of the powder of alabafter mixed with the dry powder generally directed to be ufed after the Compofition is laid on, in order to render the furface harder, and of courfe, better able to refint the bad effects of the dripping of trees, of rain, frof, and fnow. But this addition is by no means neceffary in the ufual application to the fides of trees.

In confequence of this procefs, the vigour of the roots will operate fo powerfully in the courfe of the fucceeding Spring, that a confiderable number of buds or branches will thoot forth round the ftump, which, with proper care and attention, may be trained to many valuable purpofes, either ftraight or crooked, for knee-timber, or other ufes: and, by retaining only fo many of thefe thoots as are defigned to grow for any particular intention, more than one half will be faved, in point of time, according to the proportions of common growth: for if a young tree be planted in a foil equal in quality to the fite of the old ftump, the thoot growing from 
from the latter will, in eight or ten years, attain to a fize which the fingle plant will hardly acquire in twice that period. There are alfo many ufeful purpofes of hufbandry, as hop-poles, and other poles ufed on various occafions, for which a number of thoots may be trained from one fump, whofe fertile juices will thortly rear a healthy and numerous offspring around it. Very particular attention, however, Thould be paid to regulate their number, according to the fize and vigour of the ftump. It would certainly be proper to leave more of them at firft than are intended to be referved for final ufe, in order to draw up the fap: if too few are left, they will be liable to burft, from the fuperabundant flow of the juices from the old ftock: to prevent which inconvenience, they thould be cut away by degrees, always applying the Compofition as they are cut, and leaving the finent ftem to produce the new tree, which will, in time, cover the old ftump, and leave nothing but a faint kind of cicatrix at the junction of the old and new part of the tree.

It is needlefs for me to infift on the great advantages which land-proprietors and farmers will derive from this method of managing their woods and coppice grounds, wherever they may be. In many counties of England, coppice, or underwood, is an article in very great demand for charcoal, common fuel, or the purpofes of particular manufactories, as well as to furnith a variety of articles for hufbandry and domentic convenience.

It would be equally unneceffary to enlarge on what muft be fo evident to the moft ordinary underftanding, the great national advantage which may be derived from the ufe of this Compofition, by preferving and increafing the native fupplicis 
304 OBSERVATIONS O,N THE DISEASES, \&c.

of our country for the fupport of that navy which is to protect it. Nor need I urge to the man of tafte, and the lover of landfcape beauty, what a ufeful help it may afford to the delightful modern art of ornamental horticulture. 
A P P E N D I X.

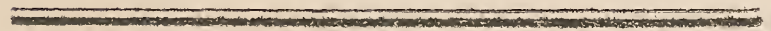

$\mathrm{R} R$ 



\section{A P P E N D I X.}

\section{$\mathrm{N}^{\circ}$ I.}

SIR,

Land Revemue Office, April 17, 1789.

BEING informed that you have difcovered a method of curing defects in growing trees of all ages, which may have fuftained damage from any caufe whatever, we with to be favoured by you with an anfwer to the following queftions, relative to injuries done to the bark of oak-trees, and the means of preventing defects in the timber arifing from that caufe, viz.

I. Suppofing a piece of bark of five or fix inches fquare to be cut from the fide of an oak-tree of any fize, from twenty feet to one load or more, fo as to lay the wood bare, and that letters or figures were burnt, or ftamped with Marp inftruments, into folid wood, where the bark was fo taken off, and the tree left in that ftate fo long as it hould continue ftanding, what effect do you think would be produced by fuch procefs upon the body of the tree; whether it would continue to grow, and increare in fize in the part from which the bark was taken; or whether any, and what detriment would enfue from it to the timber, if no means were ufed to prevent it; and whether fuch detriment, if any, would extend further than the limits of the part deprived of its bark?
$\mathrm{R}: \mathrm{R} 2$
2. If 
2. If you thould be of opinion that oak-trees would fuftain any material detriment, or become in any degree defective, from the caufe above ftated, do you know any means by which fuch detriment may be effectually prevented, in trees. which have remained in that ftate from four, five, or fix: months to a year; fo as to reftore the bark, and prevent the trees from becoming defective, and unfit for the ufe of the navy?

3.. If you thould be able to fuggent a complete remedy for fuch defects, and if the remedy would be effected by means. peculiar to yourfelf, and unknown to others, we with to know if you would be willing to undertake to apply it, or fuperintend or direct the application of it by perfons properly infructed by yourfelf, to any number of trees that might require it in any of the royal forefts?

4. In cafe there fhould be occafion to apply fuch a remedy to a very confiderable number of trees in the ftate above defcribed, we with to know, as nearly as poffible, what expence the application would be attended with, by the hundred, or thoufand, or any given number of trees, including labour, materials, and every incidental expence.

We thall be glad to receive an anfwer to thefe enquiries: with all convenient fpeed, and are,

Sir,

Your mont obedient Servants,

JOHN CALL.

JOHN FORDYCE.

Mr. Forfyth. 


$$
(.309)
$$

$\mathbb{N}^{\circ} I I_{*}$

To the Honourable the Commissioners of the Land Revenue.

Royal Gardens, Kcrisingtom, April 24, 1789.

HoNOUREd Sirs,

To the letter you have been pleafed to honour me with, I beg in general to fay, that, from many years attention to fruit and foreft trees, I have obferved every wound, bruife, or injury; even the wanton cutting of the initials of a name on the bark of a tree has been attended with mifchief, and often brought on the deftruction of the tree, efpecially if old. In. particular I beg to fay, that, if a tree be young, Nature will. exert herfelf to recover from the injury; but, if the tree be old, it will ceafe to grow about the injured part, will not increafe in fize, the wound will daily increafe, and in time deftroy all the timber of the tree.

In anfwer to the fecond queftion, I beg to fay, that oaktrees are equally liable to decay and detriment, as all other: trees, though their decay will be proportionably flow, as they. are lefs porous than many other trees of our ifland; though. I hould add; that after oak-trees are fo far decayed as to hold water, their decay is as rapid as mont other trees. In anfwer to the queftion, "Do you know any means by which fuch. 
detriment may be effectually prevented ?" I beg to fay, that after many years clofe application, and ftrictly critical obfervation, I am fully convinced, that upon the excifion of the decayed part, and the application of a Compofition, it is poffible to heal any wounded tree, and even to reftore it to its former health, if there be only an inch or two of bark remaining to carry on the circulation of the vegetable economy. This is no theory, but is demonftrated by a great variety of experiments on fruit and foreft trees in his Majefty's Gardens at Kenfington, now under my care ; and which trees, upon examination, have convinced all thofe who viewed them of the practicability of producing the fineft, cleanert, and moft prolific branches from ftumps in a ftate of decay: and with confidence I can affert, that I have fucceeded fo well with his Majefty's fruit-trees, that by cutting out the deceafed and dead wood, the trees have produced more and finer fruit in two and three years, than a tree newly planted will in thirteen or fourteen years; and this advantageous circumftance is equally vifible in the experiments I have made on elms, where nothing remained but the bark. The oak, from experience, I find equally as curable as any other tree; the bark may be reftored, and the trees rendered as fit for the navy, as though they never had been injured.

In anfwer to the third queltion, I fay, that I am able to "fuggert a complete remedy for the defeets;" and that remedy I fuppofe to be known only to myfelf, as it is not a fecret drawn from books, or learned from men, but the effeet of clofe application, and repeated experiments. As to undertaking the application of the remedy, I muft requeft you will have the goodnefs to permit me to fay, that as a fervant of his Majefy 1 do not think myfelf at liberty to form any engagement 
gagement that muft inevitably call me for a time from his Majefty's fervice in his Royal Gardens at Kenfington; but hould his Majefty be graciounly pleafed to think my fervices would be productive of a national good, and will condefcend to permit me to be abfent, I thall with the greatent pleafure and alacrity engage in the undertaking.

I beg permiffion to lay before your Honourable Board feveral fpecimens of parts of trees which have been injured in a manner fimilar to thofe you have alluded to; others which have been healed by the method I have before mentioned. But the mont effectual means of demonftrating the utility of this application, is the many fruit and foreft trees now growing in his Majefty's Royal Gardens at Kenfington, which: I thall be happy to thew you.

Your Honourable Board, confidering the Thortnefs of time, will, I truft, make every allowance for any inaccuracy in this. anfwer to the letter you favoured me with, and permit me to fubfcribe myfelf,

With the greatef refpect,

Your moft obedient

Humble Servant

WILLIAM FORSYTH.

To the Honourable the

Commissioners of the Land Revenue. 
Land Revenue Office, April 25, 1789.

\section{SIR,}

WE have received your letter of yefterday's date, which contains a very clear and fatisfactory anfwer to our enquiries refpecting the effects of injuries done to the bark of oak-trees, and the means of preventing damage to the timber from that caufe; and the fpecimens fent with your letter afford the mont convincing proofs both of the deftructive confequences arifing from even llight injuries to the bark, when no means are ufed to prevent them, and of the efficacy of your difcovery for preventing and curing defects in timber proceeding from that fource: but we obferve that you have not given an anfwer to our enquiry as to the expence which the application of the remedy you have difcovered would be attended with, by the hundred, or thoufand, or any given number of trees, in cafe there thould be occafion to apply it to a very confiderable number : we therefore repeat our requeit, that you will be fo good as to inform us, as nearly as you can, whereabouts would be the expence of fuch application, including labour, materials, and all incidental charges, but exclufive of any reward to yourfelf for difclofing the Compofition for the benefit of the public, which we conceive thould be given feparately.

We are, Sir,

Your molt obedient Servants,

JOHN CALL.

JOHN FORDYCE.

Mr. William Forsyth. 


\section{$\mathrm{N}^{\circ}$ III.}

To the Honourable the Commissioners of the Land Revenue.

Royal Gardens, Kensington, April 28, 1739.

\section{Honoured Sirs,}

I PRESUME I need not again affign the reafon why I omitted in my former letter, mentioning the expence which will be incurred by cutting out the injured parts of the trees, and the application of my Compofition. I have endeavoured to think of every probable charge that will accrue; and, upon an accurate calculation, am convinced it will not exceed fixpence per tree. It may: not be improper here to obferve, that this calculation includes the labour of the men for the operation; the Compofition, and the application of it; and alfo an after review, that the healing of the trees is going on well; but I fhould alfo obferve, that in this expence $\mathrm{I}$ have not put down any thing for myfelf, leaving that wholly and altogether to your further confideration.

I am, honoured Sirs,

With great refpect,

Your moft obedient,

Humble Servant,

WILLIAM FORSYTH.

S s 


\section{$N^{6}$ IV.}

RESOLVED,

July 24, 1789.

ThAT an humble Addrefs be prefented to his Majefty, that he will be gracioufly pleafed to give directions for making fuch enquiries as thall be thought neceffary for the purpofe of afcertaining the efficacy of a remedy invented by William Forfyth, for curing defects in trees, arifing from injuries in the bark; and in cafe the fame fhall appear likely to be of public utility, to order fuch recompence to be made to the faid William Forfyth on the difclofure thereof, as his Majefty fhall judge proper; and to affure his. Majefty, that this Houfe will make good the fame.

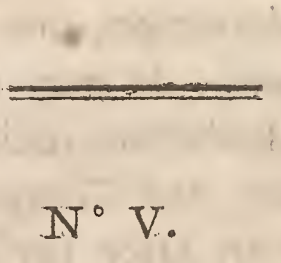

Land Revenue Office, Scottand Yard, Dec, $11, .1790$.

\section{My Lords and Gentlemen,}

Having reprefented to the Lords Commiffioners of his Majefty's Treafury, that, in purfuance of their Lordhips defire, we had written to the feveral noblemen and gentlemen mentioned in the lift, of which a copy was fent to cach of you, requefting to know whether they would have the goodnefs to make the neceffary examinations and enquiries, to afcertain the effect of the experiments made by Mr. Forfyth, 
of the Compofition difcovered by him for curing defects in trees; and that twelve of thofe noblemen and gentlemen, hereunder named, and to whom this letter is addreffed, had fignified their willingnefs to affit in the propofed examination; we have now the honour to inform you, that their lordhips have been pleafed to fignify to us, that they approve of the examination being made by thofe noblemen and gentlemen, or any feven or more of them; and to requeft that you will be pleafed to take fuch fteps as you fhall think neceffary, for afcertaining the efficacy of the faid Compofition for curing injuries and defects in trees, and to addrefs the refult of your examination to the Lords of the 'Treafury.

Among the ufes to which the Compofition in queftion is faid to be applicable, that which appears to us mure immediately connected with the objects referred by parliament to our confideration, is, the cure of injuries and defects in foreft trees, efpecially the oak: and we beg leave particularly to recommend it to you to examine,

Whether the Compofition appears to be efficacious for the purpofe of reftoring the bark of an oak-tree-which has been either cut or accidentally torn off, fo as to prevent fuch injuries or defects in the timber as are commonly found to proceed from that caufe;

And whether the application of the Compofition to the parts of foreft-trees where limbs or branches have been cut or torn off, appears to be efficacious for the preventing or curing injuries and defects in timber, proceeding from that caufe?

We prefume, with great deference, that you will think it proper to point out any other ufes to which the Compofition may appear to you to be applicable, with advantage to the 
public; and we requeft that you will be pleafed to favour us with a copy of your refolutions, or report, to the Treafury thereon.

We have the honour to be, My Lords and Gentlemen,

Your moft obedient humble Servants, CHARLES MIDDLETON. JOHN CALL. JOHN FORDYCE.

The Marquis of Abercorn.

Earl of Upper Offory.

Lord Vifcount Barrington.

Lord Frederick Campbell.

Sir George Yonge, Bart. K.B.

John Rolle, EJq.

Philip Stephens, Efq.

C. M. Pierrepont, Efq.

William Pulteney, Efq.

Robert Barclay, Efq.

Hans Sloane, Efq.

William Mainwaring, Efq.

To the Lords Commissioners of his Majesty's Treasury.

MY LORDS,

HAving met on Saturday, at Kenfington, in compliance with the defires of your Lordhips, communicated to us by the Commiffioners of the Land Revenue, we endeavoured to take every meafure for the invertigation requefted of us that 
that the time and circumftances permitted; and we conceive that the beft and mont fatisfactory mode of reporting to your Lordhips the refult of that inveftigation will be, to fpecify, as thortly as may be, the fteps we took; the obfervations we made; and our opinions, founded both upon what we ourfelves faw, and upon fuch documents as appeared to us authentic and convincing.

After referring to the laft letter addreffed to us by the Commiffioners, in order that we might keep in view, as much as poffible, the objects more particularly recommended to our attention, we proceeded firft to read a ftatement by Mr. Forfyth of the properties of his Compofition, and then to infpect and examine the various fpecimens and documents laid before us by him, tending to prove and illuftrate thofe properties.

Our inveftigation, thus far, having proved as fatisfactory as the nature of it admitted, we thought it right to require $\mathrm{Mr}$. Forfyth to thew us fuch trees in Kenfington Gardens as (having been injured or decayed by whatever caufe) had been benefited by the application of this Compofition; and we defired him to thew us what fpecimens he could of fuch trees in all the ftages of their amendment and recovery. In confequence of this requifition, we were conducted to many foreft-trees of different kinds, (viz. Elms, Limes, and Horfe-Chefnuts) in which holes and wounds, in fome inftances feveral feet in length, and of a confiderable width and depth, had been completely filled up with found wood, fo as the outline of the wound remained barely difcernible in the bark. We examined many others in an evident ftate of progrefs towards a fimilar cure, and we could not difcover any one of the experiments that fell under our obfervation, 
tion, of which we had the leaft reafon to doubt the fuccefs. We examined alfo feveral experiments upon trees which, ftanding near each other, had been cut down, and to the ftems of which the Compofition had been applied, while the others had been left to nature: the uniform refult of thefe experiments appeared, that thofe ftems to which the Compofition had been applied had thot up into healthy vigourous trees, in far lefs time than we thould have conceived poffible: while thofe, left to unaffifted nature, had only produced irregular, unhealthy fhoots, and were apparently in a ftate of decay. Several experiments had alfo been made on decayed and hollow ftumps (where little or nothing but bark remained) of Elms of very comfiderable fize and age: from thefe tumps, by the application of the Compofition, healthy trees have iffued, which have, in the fpace of five, fix, feven, or eight years, attained to a fize and height which it appears to us that trees fown or planted feldom attain to in thrice the time. With a view to afcertain, as far as was in our power, the quality of that wood which by the application of the Compofition had been formed in the decayed and injured parts of trees, we cut pieces of it out, and compared them with other picces cut out of the original wood of the fame trees, and, after as accurate a fecreting and comparifon as we were enabled to make, we could not difcover any difference either in the colour or texture.

Upon our obferving to Mr. Forfyth, that we had not yet feen any fpecimens of theoperations of his Compofition upon Oak-trees, he informed us, that, having at firt confined his experiments to other trees, which were in a ftate of greater decay, he had none of the fame date (viz. from two to eight years) to thew us, but that we might fee many fpecimens, of 
near two years ftanding, equal in their progrefs to the reft: accordingly we examined various experiments upon oaks; of which the progreffive ftate was fo perfectly fimilar to that of the other fpecies of trees, that we thould not be juftified in any doubt upon that head; the event, alfo, of comparing the new wood with the old was the fame.

To report at large our obfervations upon the effects of the Compofition applied to different fruit-trees, would be little more than a repetition of what we have already faid; the time of the year would only allow us to remark the rapid growth of the branches and thoots wherever the Compofition had been applied to the moft decayed and injured ftems.

We deem it unneceffary to enter into any detail of the collateral information and documents which confirmed the impreffions refulting from our perfonal obfervations, perfuaded that your Lordihips will believe we omitted no means in our power to form our judgments.

We will therefore only add, that, from all we faw and heard, we have reafon to believe, and confequently do not hefitate to exprefs our conviction, that Mr. Forfyth's Compofition is a difcovery which may be highly beneficial both to individuals and the public.

We have the honour to be

Your Lordhip's obedient Servants,

ABERCORN.

FREDERICK CAMPBELI.

GEORGE YONGE.

WILLIAM PULTENEY.

CHARLES PIERREPONT.

PHILIP STEPHENS.

ROBERTT BARCLAY.

HANS SLOANE。

JOHN ROLLE.

WILL" MAINWARING. 


\section{$\mathrm{N}^{0} \mathrm{VI}$.}

IN confequence of an Addrefs of the Houfe of Commons to his Majefty, and of an examination made by

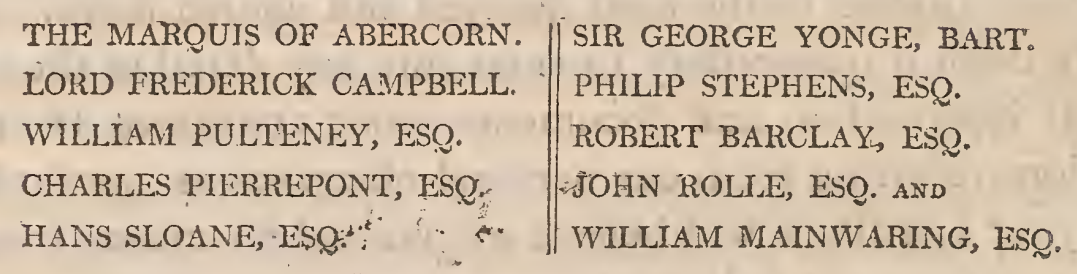

and their report to the Lords Commiffioners of his Majefty's Treafury, refpecting the efficacy of a Compofition difcovered by $\mathrm{Mr}$. William Forfyth, for curing injuries and defects in trees, his Majefty has been pleafed to grant a reward to Mr. Forfyth, for difclofing the method of making and ufing. that Compofition; and the following directions for that purpofe are publinhed accordingly: 
$(321)$

Royal Gardens, KEnsington, Rlay 11, 1791.

Directions for making a Compofition for curing Difeafes, Defects, and Injuries, in all Kinds of Fruit and Foref Trees, and the Method of preparing the Trees and laying on the Compofition, by WiLliam ForSYTH.

TAKE one buthel of freth cow dung, half a buthel of lime rubbih of old buildings (that from the cielings of rooms is preferable), half a buhhel of wood athes, and a fixteenth part of a burhel of pit or river fand: the three laft articles are to be fifted fine before they are mixed; then work them well together with a fpade, and afterwards with a wooden beater, until the ftuff is very fmooth, like fine planter ufed for the cielings of rooms.

The Compofition being thus made, care muft be taken to prepare the tree properly for its application, by cutting away all the dead, decayed, and injured part, till you come to the freth, found wood, leaving the furface of the wood very fmooth, and rounding off the edges of the bark with a drawknife, or other inftrument, perfectly fmooth, which muft be particularly attended to; then lay on the plafter about one eighth of an inch thick, all over the part where the wood or bark has been fo cut away, finifhing off the edges as thin as poffible: then take a quantity of dry powder of wood-athes mixed with a fixth part of the fame quantity of the arhes of 
burnt bones; put it into a tin box, with holes in the top, and Thake the powder on the furface of the plafter, till the whole is covered over with it, letting it remain for half an hour, to abforb the moifture; then apply more powder, rubbing it on gently with the hand, and repeating the application of the powder till the whole plafter becomes a dry fmooth furface.

All trees cut down near the ground thould have the furface made-quite fmooth, rounding it off in a fmall degree, as before mentioned; and the dry powder directed to be ufed afterwards Should have an equal quantity of powder of alabafter mixed with it, in order the better to refint the dripping of trees and heavy rains.

If any of the Compofition be left for a future occafion, it fhould be kept in a tub, or other veffel, and urine of any kind poured on it, fo as to cover the furface ; otherwife the atmofphere will greatly hurt the efficacy of the application.

Where lime-rubbih of old buildings cannot be eafily got, take pounded chalk, or common lime, after having been flaked a month at leaft.

As the growth of the tree will gradually affect the plafter, by raifing up its edges next the bark, care fhould be taken, where that happens, to rub it over with the finger when occafion may require (which is beft done when moiftened by rain), that the planter may be kept whole, to prevent the air and wet from penetrating into the wound.

WILLIAM FORSYTH.

William Forfyth, of Kenfington, in the county of Middlefex, Gardener, maketh oath, and faith, that the foregoing is a true account of the method of making and ufing the Compofition difcovered by him for 
curing difeafes, defects, and injuries, in fruit and foreft trees; and which Compofition was applied by him to the trees in his Majefty's Gardens at Kenfington, fhewn to the noblemen and gentlemen to whom it was referred to examine the efficacy of the faid Compofition.

\section{WILLIAM FORSYTH.}

Sworn at the Land Revenue Office, in Scotland Fard, the Eleventh Day of May, 1791, before $U_{s}$,

CHARLES MIDDLETON. JOHN CALL.

JOHN FORDYCE.

\section{$\mathrm{N}^{\circ}$ VII.}

Additional Directions for making and ufing the Compofition.

To the foregoing directions for making and applying the Compofition, it is neceffary to add the following.

As the beft way of ufing the Compofition is found, by experience, to be in a liquid ftate; it muft, therefore, be reduced to the confiftence of pretty thick paint, by mixing it up with a fufficient quantity of urine and foapfuas, and laid

$$
\text { T } T 2
$$


on with a painter's brufh. The powder of wood-afhes and burnt bones is to be applied as before directed, patting it down with the hand.

When trees are become hollow, you muft fcoop out all the rotten, loofe, and dead parts of the trunk till you come to the folid wood, leaving the furface fmooth; then cover the hollow, and every part where the canker has been cut out, or branches lopped off, with the Compofition; and, as the edges grow, take care not to let the new wood come in contact with the dead, part of which it may be fometimes neceffary to leave; but cut out the old dead wood as the new advances, keeping a hollow between them, to allow the new wood room to extend itfelf, and thereby fill up the cavity, which it will do in time, fo as to make as it were a new tree. If the cavity be large, you may cut away as much at one operation as will be fufficient for three years. But in this you are to be guided by the fize of the wound, and other circumftances. When the new wood, advancing from both fides of the wound, has almoft met, cut off the bark from both the edges, that the folid-wood may join, which, if properly managed, it will do, leaving only a llight feam in the bark. If the tree be very much decayed, do not cut away all the dead wood at once, which would weaken the tree too much, if a ftandard, and endanger its being blown down by the wird. It will, therefore, be neceffary to leave part of the dead wood; at firft, to ftrengthen the tree, and to cut it out by degrees as. the new wood is formed. If there be any canker, or gum oozing, the infected parts muft be pared off, or cut out with a proper inftrument. When the ftem is very much decayed, and hollow, it will be neceffary to open the ground and examine the roots; then proceed as directed for hollow Peach- 
trees [See Plates II. and V. which hew the manner of preparing hollow trees, and alfo the growing of the wood].

Some months before the publication of the "Obfervations on the Difeafes, \&c. in Fruit and Foreft 'Trees," I had tried the Compofition in a liquid ftate, but did not think myfelf warranted to make it public until I had experienced its effects through the Winter. 'The fuccefs anfwered my moft fanguine expectations; and I have ufed it in that way ever fince. By ufing the Compofition in a liquid tate, more than threefourths of the time and labour is faved; and $I$ find it is not fo liable to be thrown off as the lips grow, as when laid on in the confiftence of plafter: it adheres firmly to the naked part of the wound, and yet eafily gives way as the new wood and bark advances.

The firft time that I tried the Compofition in a liquid form was upon an elm which had been planted about twenty years. It had been very much bruifed by the roller, had feveral cavities in it, and was very much bark-bound befides. Having prepared the wounds, and applied the Compofition with a painter's brufh, I took my knife and fcarified the tree in four places; I alfo thaved off, with a draw knife, all the cankery outer bark, and covered the whole tree with the Compofition, thaking the powder of wood-afhes and burnt bones all over it. A very heavy rain began in the evening and con. tinued all night; yet, to my.great fusprize, in the morning, I found that only fome of the powder, which had not had time to dry and incorporate with the Compofition, was wathed off. I now repeated the powder, and, without any thing more being done to the tree, the wounds healcd up and the bark was reftored fo completely, that, three years ago, it could hardly be difcerned where the wounds had been. The fcari- 
fications had alfo difappeared. Some of the wounds were thirteen inches long, eight broad, and three deep. Since the time when it was ícarified, the tree has increafed ten inches more in circumference than a healthy tree planted at the fame time with it about fixteen feet diftant, which was not fcarified. 
S U P P L E M E N T.

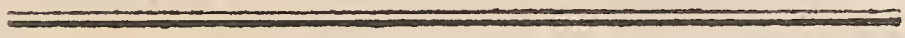




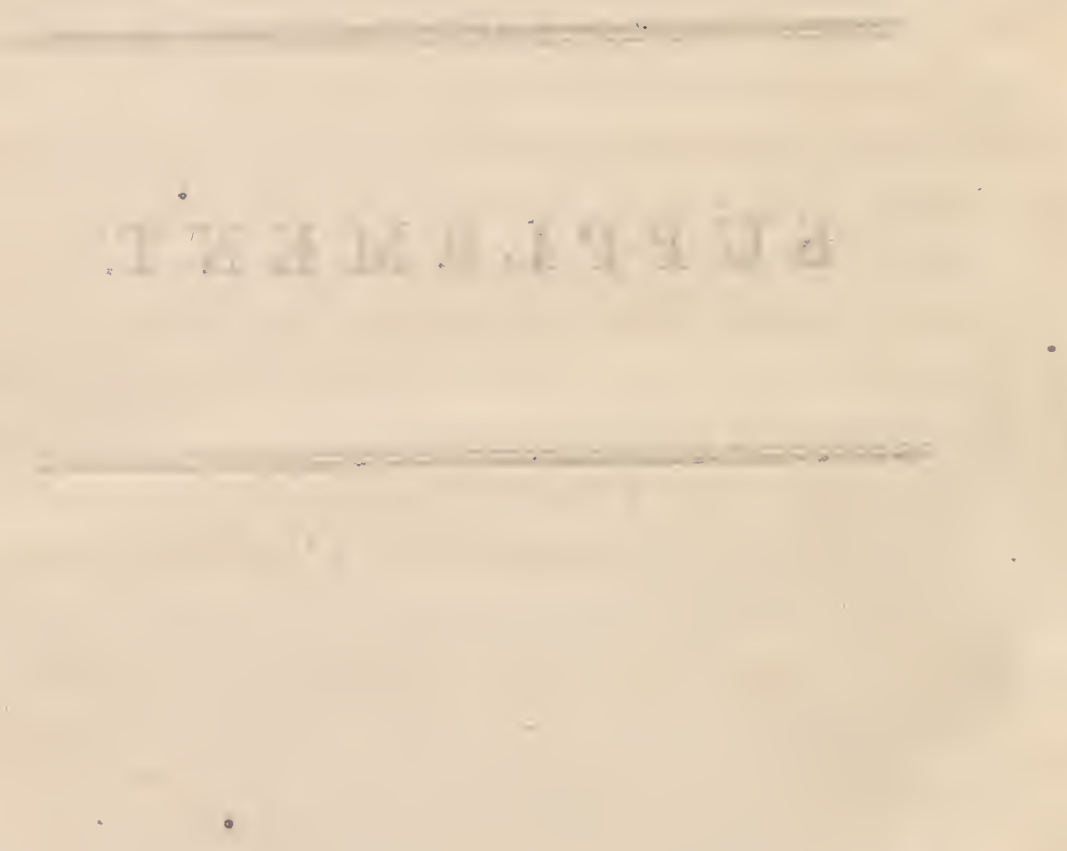




\section{S UPPLEMENT.}

\section{Success of Several Experiments, fince the Publication of "Obfervations on the Difeafes, Defects, \&c."}

SINCE I publifhed my "Obfervations on the Difeafes, Defects, and Injuries in Fruit and Foreft trees," I have been afliduous in making experiments for the fake of improvement. A great many hollow trees that had, when I took them in hand, little more than the bark remaining found, have within thefe few years been entirely filled up: others, that were headed down within a few feet of the ground, have their ftumps now completely covered by the leading thoot, forming handfome trees; and the places where they were headed are only difcerned by a faint cicatrix. Of a great many, I thall only particularize a few inftances.

A Lime-tree, about eighteen inches in diameter, whofe trunk was decayed and hollow from top to bottom, to which, after cutting out the decayed wood, I had applied the Compofition about fixteen years ago, was cut down laft year on purpofe to examine the progrefs it had made in the interior part, and was found entirely filled up with new found wood, which had completely incorporated with what little old wood remained when I firft took it in hand. The body of this tree I had cut in thort length', which I bave now in my poffeffion, 
to thew to any gentleman who wifhes to be convinced of th fact. An old Elm whofe infide was totally decayed, and ont of which, at different times, were taken two large cart loads of rotten wood, has made fnoots upwards of twenty feet high in the courfe of fix years. Another Elm, on the Palace green, which was headed about twenty feet from the ground, has produced a fhoot forty-fix feet high, and five feet nine inches in circumference. A Lime, cut down near the ground, has now a thoot twenty feet high which entirely covers the ftump, forming a fine tree twenty-one inches in circumference. A Sycamore treated in the fame manner is now thirty feet high, and twenty-fix inches in circumference. Another is thirty feet high, and two feet in circumference. Thefe are now fine thriving trees, and the cicatrices hardly difcernible.

A Horfe-Chefnut headed down has produced, from its hollow ftump, four fine thoots, one of which is cut down; the other three are upwards of thirty feet high, and one of them is twenty-fix inches in circumference. Two of the remaining three are to be cut down, leaving only one to furm the body of the tree. A Lime, whofe hollow part is eleven feet high, is alfo filling up ; the tree is a foot in diameter. A decayed part, four feet high and twenty-eight inches broad, in a large Elm, is now filling up rapidly with found wood. About two feet and a half in length on one fide, which was for fome time left to nature, ftill continued to decay till the Compofition was applied: new wood and bark are now forming. An Elm, at the back of the old fruit-room, near the garden wall, which was entirely hollow, was alfo headed down: the new head now fpreads about twenty-four feet, and is eighteen fect high. Another large hollow Elm near the lalt was headed down; it afterwards produced a hoot 
fixty feet high, and three feet and a half in circumference : the hollow was upwards of two feet in diameter. There are a great many other Elms, fome of which had wounds ten feet long and two feet broad, now entirely filled up; befides many Sycamores, Oaks, and other foreft trees, all reftored to a flourifhing ftate, by having the dead wood cut out and the Compofition applied. An Oak that was headed down about fix years ago is reprefented in PLATE XII.

In hollow trees, the rotten and decayed wood muft be cut out at different times, as the new wood comes in contact with it; but great care muft be taken not to cut out too much at once, but to leave enough to fupport the tree and prevent it from being blown down by high winds, till the new is ftrong enough for that purpofe: the remainder may then be cut out.

A number of inftances of the fuccefs attending my method of pruning and training might be adduced; but I thall notice only the following.

Mr. Aberdeen, gardener to John Sullivan, efq. at Richings near Windfor, has followed it for fome time with great fuccefs both in the houfe and on the natural wall.

Having heard for feveral years of the very fine and large crops that were produced in the foring-houfes belonging to John Julius Angerftein, efq. at Woodland-Houfe, on Blackheath, I was induced to take a journey thither, in company with John Wedgwood, efq. to fee what method was purfued to obtain fuch crops. On enquiry, Mr. Stuart, the gardener, candidly told me, that feveral years ago he had been at Kenfington Gardens, where he faw my method of pruning and training, was convinced of its advantages above the old, and had adopted it with great fuccefs. Indeed, there were, at the 
time I was there, the fineft and largeft crops: of Grapes that I had ever feen in any forcing houfes. Two houfes, in particular, were covered from top to bottom with fine Grapes, and the Vines trained in the ferpentine manner.

John Wedgwood, efq. of Cote Houfe near Briftol, a gentleman who is much attached to gardening and planting, tells me, that he has practifed my mode of pruning and training fruit-trees, particularly Peaches and Nectarines, in his houfes; and that he is highly pleafed with the method, which has been attended with great fuccefs.

Lord Frederick Campbell has lately favoured me with a lift of eighty-five fruit-trees, of different kinds, that were headed down, in his gardens at Coomb-bank in Kent, in the years 1798 and 1799 ; and afterwards trained and pruned according to my method: many of them, before heading: down, were in a very cankery, unfruitful ftate, and overgrown with mofs; thefe are now in a fruitful, healthy, and flouriming condition: fome of the Efpaliers have made thoots from two to three yards long, and upwards. Thefe trees were cut and prepared by Mr. Williams, who had been for fome time accuftomed to my way of treating fuch trees, and whom I recommended to his Lordfhip as a gardener. Thefe trees are very proper patterns for any gentlemen in the neighbourhood, who wifh to give the Compofition, and method of training and pruning, recommended in this Treatife, a fair trial.

Several fuccersful trials have alfo been made at the Duke of Dorfet's Scat, at Knowle in Kent, at Hatfield Houfe, the feat of the Marquis of Salifbury, and at a great many other places; and Experiments are now making at Sir Henry Strachey's, at Rook's. Neft, near Godfone, in Surrey.

Although 
Acthough I do not mean to enter at large on the culture and management of foreft-trees; yet as the following obfervations on raifing Oaks, and directions for planting Chefnuts for underwood, may be of confiderable fervice, I hall, without any farther apology, lay them before my readers.

\section{The beft Way of raifing Oaks.}

It is a generally received opinion, that when an oak lofes its tap-root in tranfplanting, it never produces another; but this I have proved to be a miftake, by an experiment which I made on a bed of oak plants in the year 1789 . I tranfplanted them into a frefh bed in the forementioned year, cutting the tap-roots near to fome of the fmall fide-roots or fibres thooting: from them. In the fecond year after, I headed one half of the plants down, as direeted for Chefnuts, and left the other half to nature. In the firt feafon, thofe headed down made thoots fix feet long and upwards, and completely covered the tops of the old ftems, leaving only a faint cicatrix, and had produced new tap-roots upwards of two feet and a half long. One of thefe trees I left at the Land Revenue Office, for the infpection of the Commifioners, and to Thew the advantage of tranfplanting and heading down young oaks, when done in a proper manner. By this mode of treatment they grow more in one year than in fix when raifed in the common way. The other half of the plants, that were not headed down, are not one fourth the fize of the others. One of the former is now eighteen feet high, and, at fix inches from the ground, meafures fifteen inches in circumference; at three fcet from 
the ground, ten inches; and at fix feet, nine inches and a half; while one of the largent of the latter meafures only five feet and a half high, and three inches and three quarters in circumference, at fix inches from the ground. This is a convincing proof, that tranfplanting and heading down oaks is the moft fuccefsful and advantageous way of treating them; and by it they are fooner out of danger from cattle, as well as from vermine, which are frequently very injurious to young trees.

\section{Of raifing Chefnuts for. Underwood.}

As the Chefnut is the beft and moft durable wood for ftakes, hop-poles, \&c. I thall give fome directions how to plant them to the beft advantage for copfe wood.

For this purpofe, the ground fhould be trenched, or ploughed, and well fummer-fallowed. After the fall of the leaf, plant the young trees in the Quincunx order, in rows fix feet apart, and at the diftance of fix feet in the rows from plant to plant. If you are forming large plantations, the moft expeditious way will be to plant after the plough, treading the earth firmly about the roots of the plants. It will be neceffary to form bafins round the plants on purpofe to mulch them, if it thould happen to be a dry feafon the firft Summer after planting. It may, perhaps, be a faving of time to put the plants in loofely at firft, that you may be able to keep up with the plough, and to return afterwards to tread the mould, and form the bafins for mulching.

When the trees are become fit for poles, every other one may be cut down almoft clofe to the ground, throughout the 
plantation; always obferving to cut in a floping manner, and as near to an eye as may be. Thofe that you intend for timber fhould be left in every other row, which will leave them twelve feet apart every way: but if the foil be rich and deep, it may be neceffary to leave them twenty-four feet apart. In many counties, particularly Hertfordfhire, the underwood is more valuable than timber; in that cafe it will be more judicious to leave but few trees for that purpofe: in the mean time the underwood will amply repay you for the expence of planting, \&c. befides the rent of the ground, while at the fame time you have a fufficient crop of timber on the ground. In Kent, they generally plant out Chefnuts and Afh for hoppoles at three years old, and cut them fourteen years after, which makes, in all, feventeen years before they are fit to cut; and they bring from one guinea and a half to two guineas per hundred; but if they were raifed from large ftools, properly cut, and the Compofition applied, they would be fit for cutting in lefs than one third of that time; and, of courfe, the value of the land would be tripled. 


\title{
L E T T E R S
}

\author{
ON THE
}

EFFECT OF THE COMPOSITION IN ALL CLIMATES.

THE following letters, \&c. are inferted to thew that the Compofition, when properly applied, is found to be equally efficacious in all climates, foils, and fituations. Indeed, all who have given it a fair trial are fo fully convinced of its utility, that many noblemen and gentlemen have fent their gardeners, to me for inftructions. The Chevalier D'Almeida, the Portuguefe Ambaffador, had a perfon fent from Portugal for the fame purpofe; and fome Polifh noblemen, who had feen the trees in Kenfington Gardens, were fo fully convinced of the great advantage to be derived from the application of the Compofition, as to fend a man for inftuctions, that he might introduce the practice into Poland.

Copy of a Letter from the Economical Society of St. Peterfourg.

Imperial Corps of Land Cadets, in St. Petersburg, SIR, January 9, 1792.

As a member of the CEconomical Society of St. Peterfburg, his Excellency Count Anhalt folicits me to exprefs, in your own language, the pleafure which the communication of your ufeful difcovery has given him, and the learned body over 
over whom he fo worthily prefides. The Count has already taken the neceffary fteps, by defire of the Society, to have your little differtation tranflated and printed in the Ruffian Language, in order to diffufe the advantage it holds out, as widely as poffible, over this vant Empire. I am happy in the opportunity his commiffion offers, of expreffing likewife individually the fatisfaction $I$ have received, as a countryman and lover of Botany, from the perufal of your fagacious application of the Chirurgical art to vegetation; and muft own, that your extirpation of the difeafed parts, and the ufe of an unguent to ward off the noxious action of the air and humidity, during the exertions of nature to repair lofs of fubftance, and the languid circulation of the vegetable juices, appear to me highly judicious. The analogy in certain refpects between the inferior order of beings, to particularly your care, and the more animated link of the great chain of Creation, feems to become every day more and more apparent. Nay, if we are to credit the ingenious Author of the Philofophy of Natural Hiftory, lately publifhed in Edinburgh, it is not a little evident; and indeed the great number of curious facts and obfervations which he has brought together render his phrafe, which I have ufed above, much lefs improper than it would have otherwife appeared on the face of the cafe. All thefe confiderations then make me fee, with the more pleafure, the fagacious application of at leaft one branch of the healing art to certain difeafes of vegetables, to the advantage of the world in general, and the Britifh Navy in particular, which muft gain infinitely by the prefervation and health of Britifh Oak, unrivalled for the noble purpofe to which it is applied.

I have ftill to congratulate you on your becoming, fo $\mathrm{X} \times$ defervedly, 
defervedly, a member of our Society; for fure no treatife ever - laid before us promifed a wider field of public and private CEconomy, and of courfe none ever came more immediately under the fpirit and purport of our inftitution.

I am, Sir, with hearty withes for the fuccefs and extended range of your purfuit,

Your moft obedient, humble Servant, (Signed) MATTHEW GUTHRIE.

To Mr. Forfyth, Kenfington.

P.S. As the extremes of our climate may produce cafes which are not likely to happen in your temperate illand, Count Anhalt will be happy to fee more obfervations on fuch accidents in any future letter you may addrefs to the Society. A paper of mine on the Ruffian Climate, in the fecond volume of the Philofophical Tranfactions of the Royal Society of Edinburgh, may probably afford you all the information neceffary to judge of what modification your fyftem may require in this country, although I do think it applicable every where, with poffibly fome little alteration in the confiftence of your plaiter, to fuit extremes of heat and cold. This letter being of a public nature, intended to tefify the fenfe of the Economical Socicty of Peterfburg, on your ufeful difcovery, you may make what ufe of it you pleafe. 
Copy of a Letter from George Sulivan Marten, Efq.

Enston, Oxfordshire, July 30, 1800.

Sir,

UNDERSTANDING there exifts fome doubt how far your vegetable plafter anfwers in hot climates, I cannot in jultice hefitate to inform you, that it was in conftant and fuccefsful ufe not only in my own garden in the diftrict of Trinfivelly, four hundred miles South of Madras, but alfo in the Company's Cinnamon Plantation which I had the pleafure of forming there, and where, from the method of cultivating that fpice, the trees are always cut down to ftumps. Your plafter at thefe times was always applied, which ftopped the bleeding, and haftened out the fhoots (from whence the beft Cinnamon is taken) much quicker than the former mode (and which is ftill practifed in Ceylon I believe) of heaping the earth over them. Nor was my experience confined; for, when I quitted India in October I798, I left one hundred and fifty thoufand trees and plants in the Trinfivelly Plantations, all of which I had planted from the feed of two trees brought from the Inland of Ceylon by Mrs. Light, which are yet flourining, I dare fay, in the Commercial Refident's garden.

I likewife applied your plafter with equal fuccefs to the fruit-trees of the country. But to an old Pumbilmos, or Shaddock tree, which was almont throughout decayed, and

$$
\mathrm{Xx}_{2} \text { which }
$$


which I had to fill up with the plafter after the dead wood was taken out, it produced wonderful renovation. I derived too much benefit from this Compofition to finifh without affuring you, that I will with much pleafure give you any further information as to its fuccefs in hot countries that came within my obfervation during the ufe of it for feveral years in the diftrict of Trinfivelly.

I am, Sir,

Your moft obedient Servant, (Signed) GEORGE SUIJIVAN MARTEN.

To Mr. Forfyth.

Copy of a Letter from John Wedgroood, ESq.

Cote House, Nov. 14, 1800.

DEAR Sir,

W HEN you were with me you expreffed a wifh to have the number of Peach and Nectarine trees which $I$ had on my walls that had been dreffed with your Compofition. Thefe trees were part of a fet which 1 bought in a lot, and which had been left to grow rude againt an old wall, fo that they appeared to be gone paft all cure. Many were eaten up with the canker, and many were become fo naked at the bottom that they gave but little room to imagine they could be brought into any form. I planted them againft my walls in the beginning of the year, where they were left unpruned till 
the middle of May. The gardener then gave them a fevere cutting in, and, as he went on, conftantly dreffing them with your Compofition, carefully eradicating all the canker. I can now fafely fay, that they are as free from canker as any trees I ever faw, and full of fruit-bearing wood, many of them brought into excellent form, and all of them, except fome few which died in the Summer, promifing to make very ufeful and profitable trees; fo that if I had occafion to new ftock my walls, I thould as willingly purchafe another fuch lot as buy regular trained trees from a nurfery. Provided the roots are good, I am convinced from experience, that the older the tree the more profitable it will be, as in the cafe of the trees above defcribed; all the young thoots are covered with bloffom buds in great profufion.

The following is the lift of the trees, and the afpects of the walls on which they are planted.

I9 Peach and Nectarine trees on a new wall by the hothoufe, Eaft afpect.

I 6 do.... do...... on another, Eaft afpect.

19 do..... do...... on the fame afpect,

5 do.... do...... on a South afpect.

2 do..... do...... on another South wall.

4 do............ on another South wall.

65 in all.

Thefe are exclufive of many trees that were on the walls before, and which have been much benefited by being dreffed with your Compofition. I am fo fully aware of the excellence of the Compolition, that I do not permit the gardener to prune any plants without immediately ufing it. If you 
think thefe remarks can be of any fervice, you have my permiffion to make any ufe of them.

$$
\begin{aligned}
& \text { I am, dear Sir, } \\
& \text { Yours fincerely, } \\
& \text { (Signed) JOHN WEDGWOOD. }
\end{aligned}
$$

Extract of a Letter from Thomas Davis, Efq. Author of the Agricultural Survey of Wilthire.

June 28, 1801.

"I WAS happy in having an opportunity the other day of thewing the effects of your plafter (in recovering the bark of oak-trees of 4 or 500 years old, which had begun to rot upwards from the ground, and is now recovering downwards very rapidly,) to Lord Spencer, who was both pleafed and aftonifhed with it.

"You may at any time refer to me for proofs if you want them. I made a bold experiment feven years ago on an Oaktree 40 feet high and $16 \frac{x}{2}$ feet round, worth $f_{0} .80$ at leaft to a Carpenter to cut to pieces, and fuch a tree as the King has not ten in his dominions. There was a craze in the fide of it, which looked like a thake, and fpoiled its beauty. I cut out the bark on each fide the fiffure fo as to make the opening 6 or 7 inches wide. I coated it well with plafter, and it is now perfectly united and found."

"In the annexed Figure, a reprefents the Fiffure which feparated the Bark, but did not affect the wood."

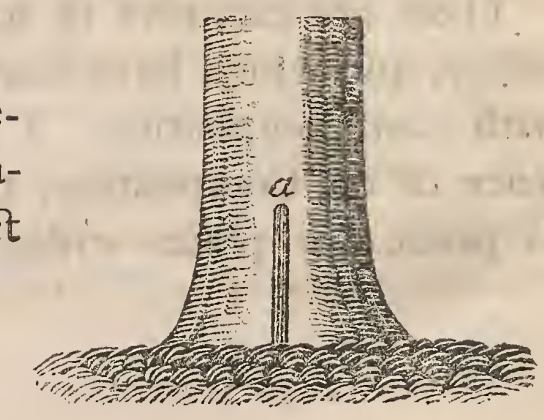


$(343)$

Directions for Heading doren Orange-trees.

JUST as the manufcript was going to the prefs, Mr. Rademaker, the Portuguefe Agent in London, called and told me, that he had received a letter from the Chevalier d'Almeida, the late Ambaffador from Portugal at this Court, informing him, that on his return home he had found the Orangetrees on the Prince of Brazil's Plantations in a very unhealthy and decayed ftate; and requefting him to apply to me for fome of the Compofition, and a copy of the Pamphlet "On the Difeafes, \&c. in Fruit and Foreft Trees;" as he withed to make trial of it on the trees of that country.

Accordingly, I have fent a cafk of the Compofition, with directions for preparing the trees, and laying it on.

When it is found neceffary to head down Orange-trees, I would advife not to cut them quite down to the ftem; but to leave two or three inches of the branches; fome more, fome lefs; always remembering to cut near to a joint, and in fuch a manner as to form a handfome head; and to apply the Compofition immediately. In doing this, however, it will be neceffary to leave a few young thoots to draw up the fap. If the trees are infefted with infects, the ftems muft be wafhed with foapfuds and urine, and well fcrubbed with a hard bruth.

About twelve years ago the Orange-trees in the green houfe in Kenfington gardens were fo much infefted with a fpecies of coccus, that I was obliged to head them all down, and 
clean off the infects as above directed; applying the Compofition immediately after. Thefe trees throve amazingly; and in three years, without any bottom heat, the heads were as, large as before they were cut; and they ftill continue in a: flourithing and fruitful ftate.

1 would advife to rub off the fide thoots, as directed for other fruit-trees, and to keep the heads thin of wood.

I thought it proper to infert the above for the information of thofe who have Orange-trees in this country, as well as for thofe who have them abroad. 


\section{EXPLANATIONS}

E N G R A V I N G S.

$$
\mathrm{Y} \mathbf{Y}
$$




\section{EXPLANATION OF PLATE I.}

Fig. $I$.

REPRESENTS an old Apricot-tree, after the laft pruning in Summer, in the fourth year after heading down. The lower part of the trunk is reprefented as covered with a rough bark, which muft be pared off when it happens to be cankery. $a, a, a, a$. The cicatrices of the four different years' heading, which thould be performed at the time of the Winter or Spring pruning.

$b, b, b$. Forked thoots which are laid in, in Summer, and cut off at $b$ in the Winter pruning, that the leading thoots may be always left without forks.

As the fmall thoots $c, c, c$, from the ftem, advance, the larger forked thoots fhould be cut out, as at $d, d, d$, to make room for them to be trained horizontally.

\section{Fig. $I I$.}

Is an old branch of an Apricot trained up according to the old method, leaving above three fourths of the wall naked. Such branches thould be cut down as near to the place where the tree was firft budded as poffible, as at $e$, on purpofe to fill the wall with fine new wood. 


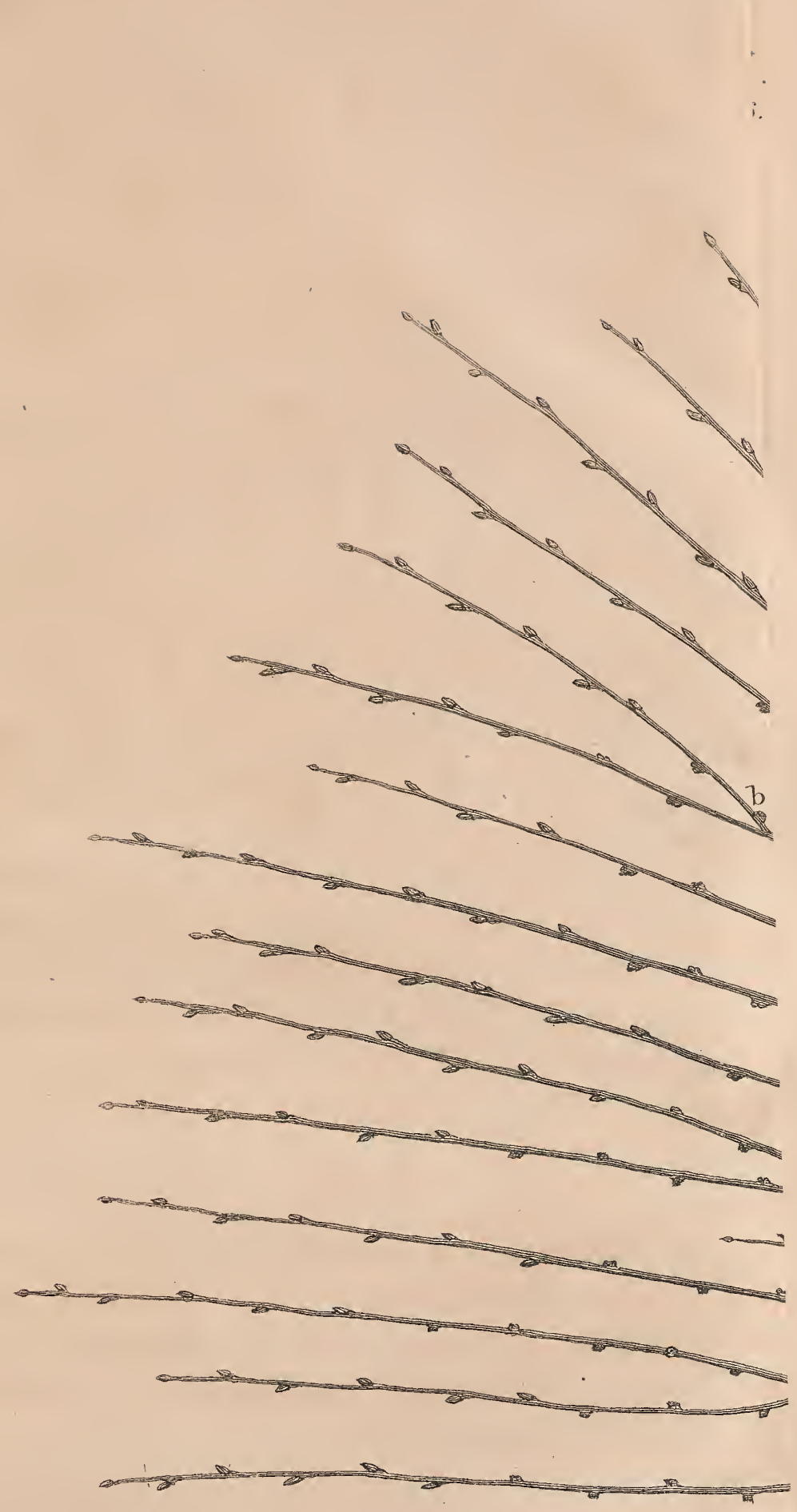



A IP IR II CQ (O) VI

Plate I.
To face page 346.

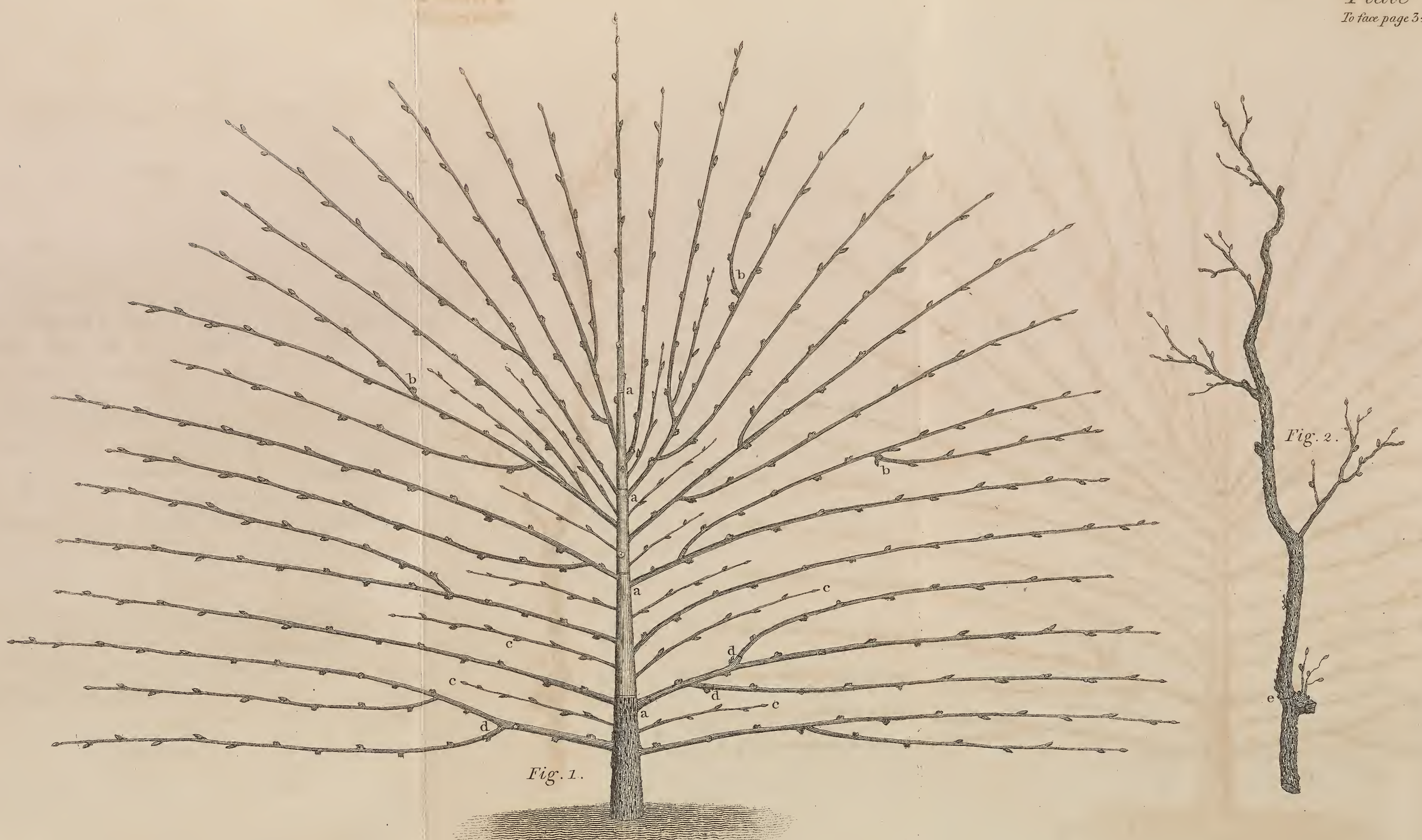






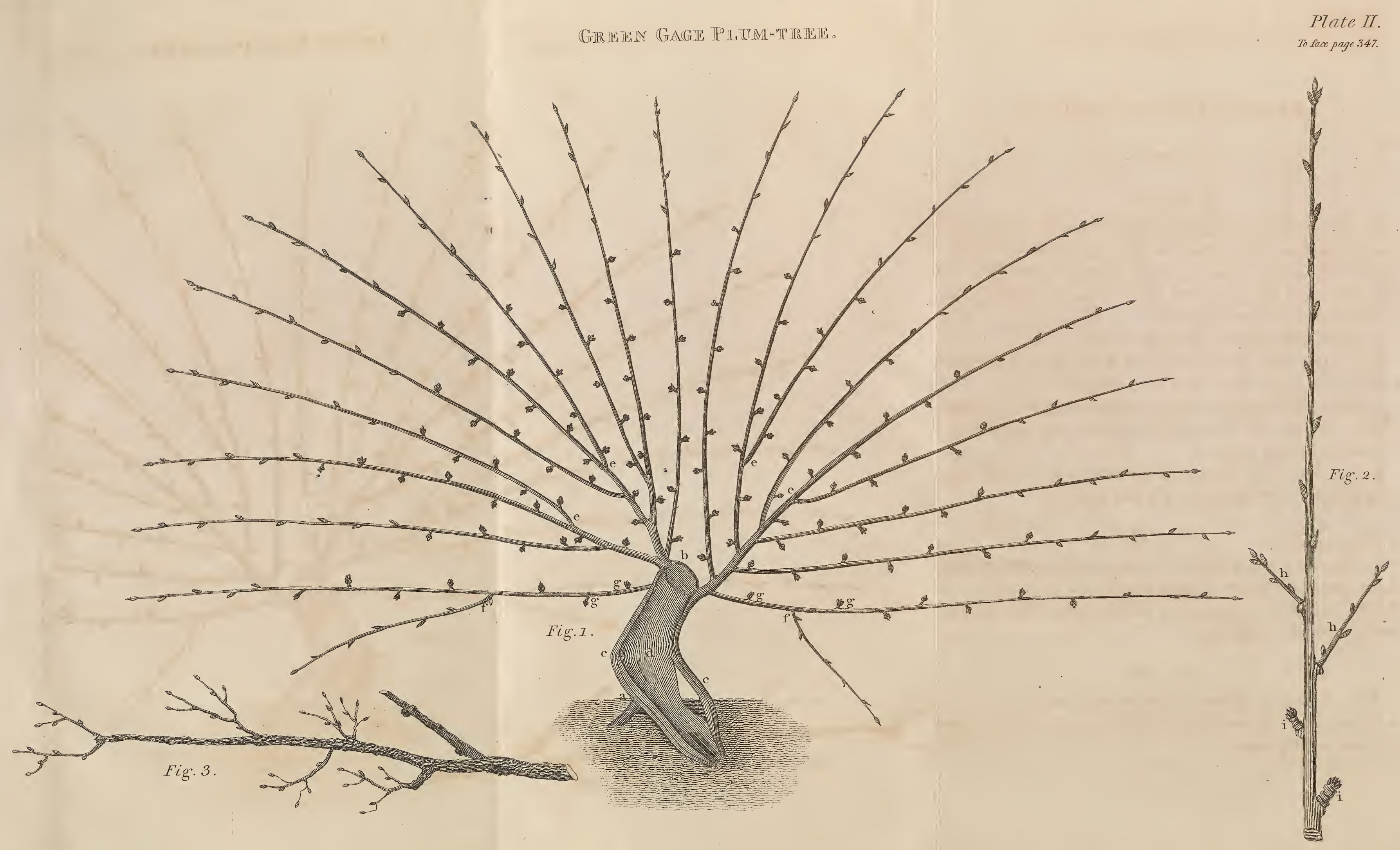



Plate II.

To face page 347.
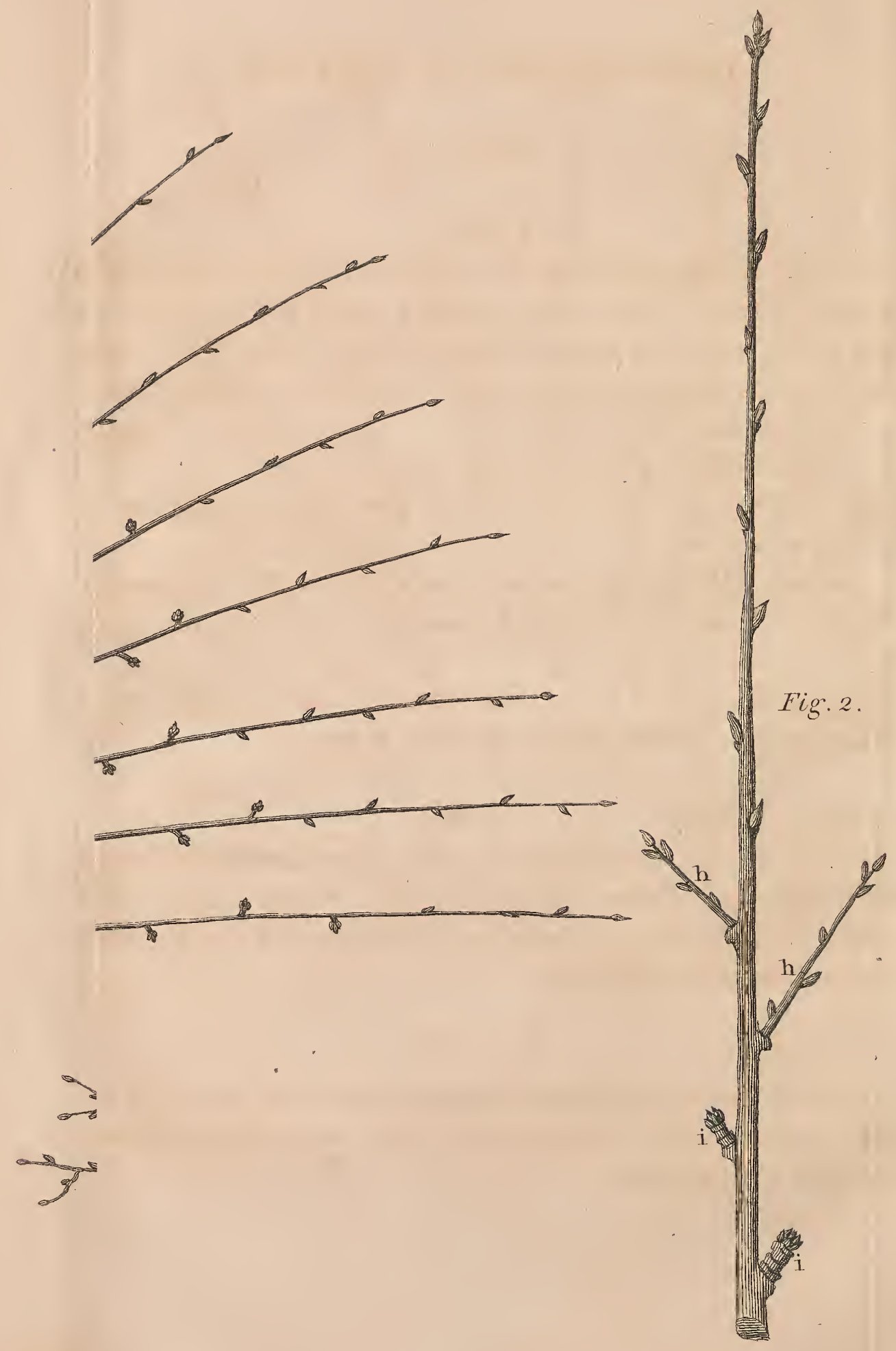


\section{EXPLANATION OF PLATE II.}

- Fig. I.

AN old hollow Green-gage Plumtree the fecond year after heading down. This tree was very much decayed, having only a few inches of found bark; many of the roots, being alfo rotten and decayed, were cut off, and an incifion made at $a$, which produced a frefh root.

b. The firt heading, clofe to a bud.

$c, c$. The new wood and bark growing over the hollow part $d$, which is covered with the Compofition.

$e, e, \& c$. Where the fecond year's heading was performed. $f, f$. Where the foreright thoots are cut off during the Winter or Spring pruning.

$g, g, g, \& c$. The fruit buds for next year, as they appear after the foreright thoots are cut off, as at $f, f$.

Fig. II.

A branch on a larger fcale, to fhew the manner of cutting thofe foreright thoots which are full of fruit buds. This fhould be done at $h, h$, but not till the fruit is fet ; they afterwards form into dugs as $i, i$.

Fig. III.

An old branch pruned in the common way, covered over: with canker, and producing only fmall weak thoots, leaving; the wall moftly naked. 


\section{EXPLANATION OF PLATE III.}

Fig. $I$.

An old hollow Peach-tree, after the laft nailing in Summer, which had been headed down at $a$ four years ago. The hollow is covered over with the Compofition, and now nearly filled up. The heading mut always be done as near to a bud as poffible.

$b, b, \&$ c. Where the forked branches are to be cut, when the fmall thoots $c, c, \&$ c. are far enough advanced, that thefe may be trained horizontally.

When a thoot has fingle fruit-buds to the top, as at $d$, it muft not be fhortened, but laid in at full length; or, if not wanted, it muft be cut clean out.

Fig. II.

A branch on a larger fcale.

$e, e$. Are double flower-buds, with wood-buds between them : the fhoots Thould always be cut at fuch; but never at a fingle flower-bud, as at $f$; otherwife the fhoot would die to the next wood-bud; and, if the pruning were done in a carelefs manner, would endanger the whole hoot. Thofe above $f$, are all wood-buds.

Fig. III.

A branch of an old Peach-tree pruned in the common way, which fhould be cut at $g$, and the young wood will foon cover the wall. 


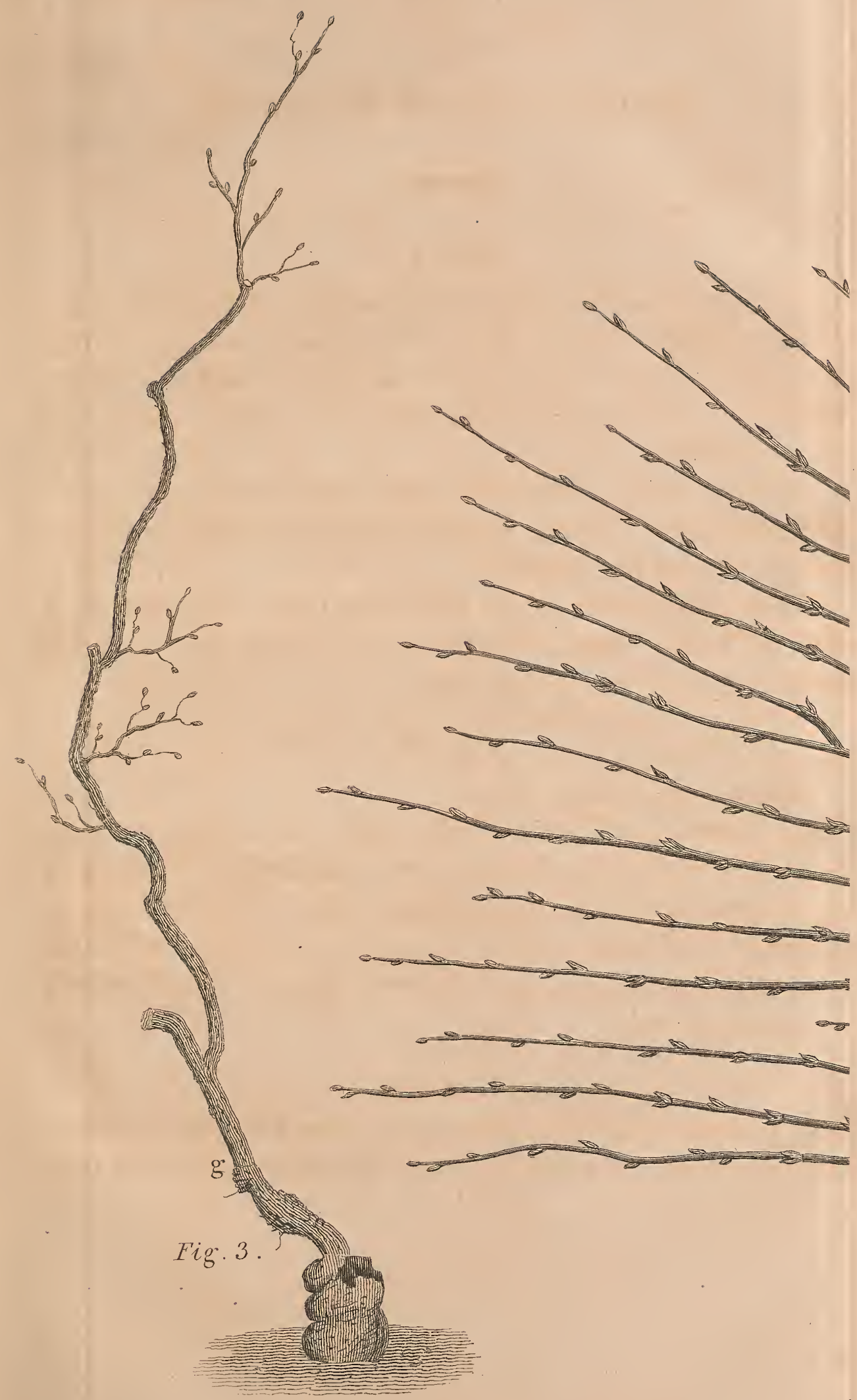








Plate IV.

To face page 349.

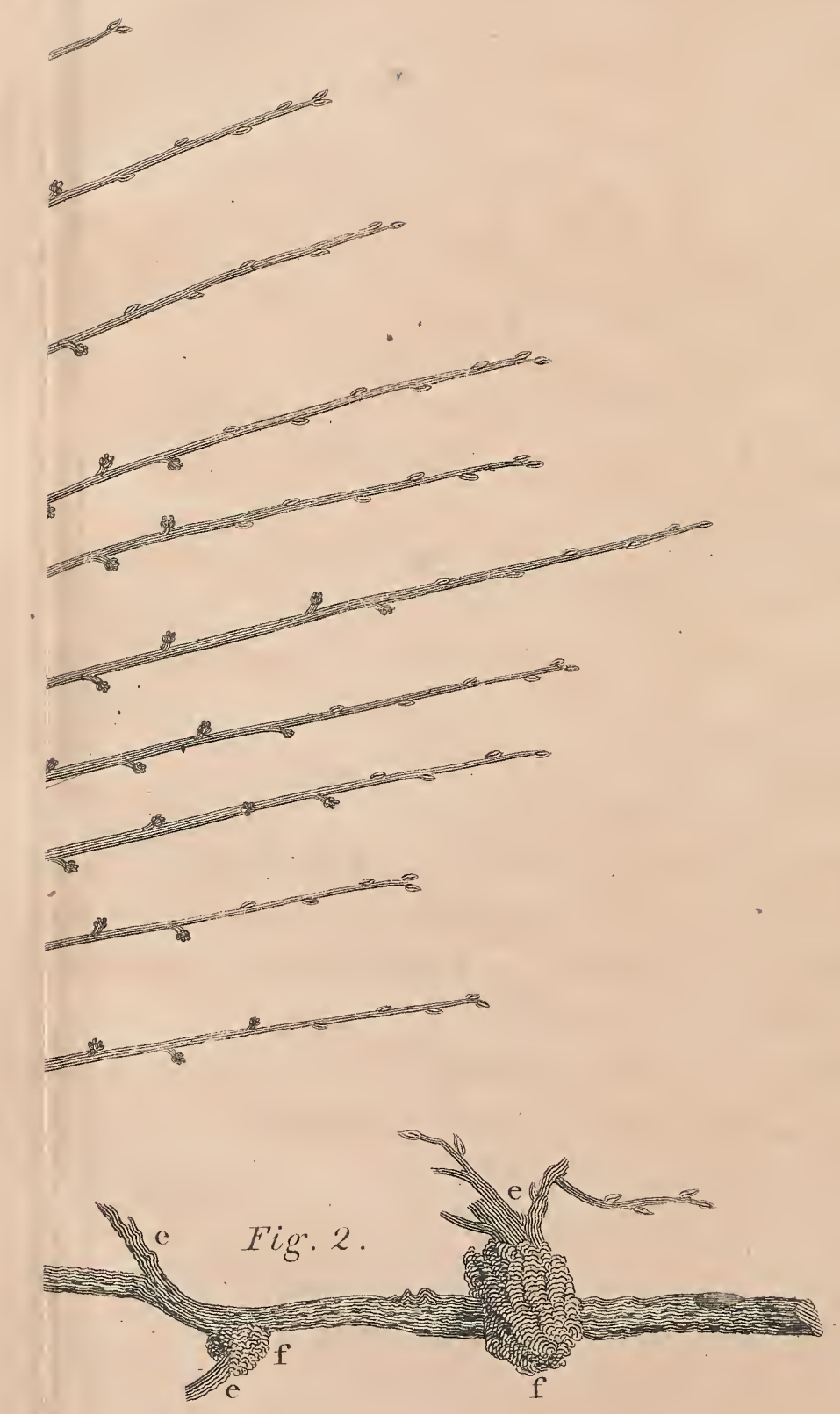

G. Chris:

H. Mutlow Sculp. 
EXPLANATION OF PLATE IV.

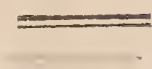

Fig. I.

An old Cherry-tree headed down at $c$. Before this its branches were covered with the gum and canker, as Fig. II.

The foreright thoots hould be tucked in, as directed for Pears; and at the fall of the leaf, or in the month of February, they thould be cut at $a$ : thefe form the fruit-buds $b, b, \& c$. all over the tree.

$c, c, \& c$. The cicatrices where the leading thoot was headed in different feafons.

$d, d$. The Compofition applied where large limbs were cut off.

Fig. II.

A branch of this tree before it was headed down.

$e, e, \& c$. Branches injudicioufly pruned in Summer; which brings on the death of the thoot, and afterwards the gum and canker on the tree.

$f, f, \& c$. The gum and canker in the laft ftage, which corrodes the whole tree if not carefully extirpated. 


\section{EXPLANATION OF PLATE V.}

As old Cherry-tree, reftored from two or three inches of live bark, taken from the wall, and planted out as a dwarf ftandard: now very fruitful.

$a, a$. The cicatrices where it was headed down the firft and fecond time.

b. The hollow covered with the Compofition, and now nearly filled up with found wood. 


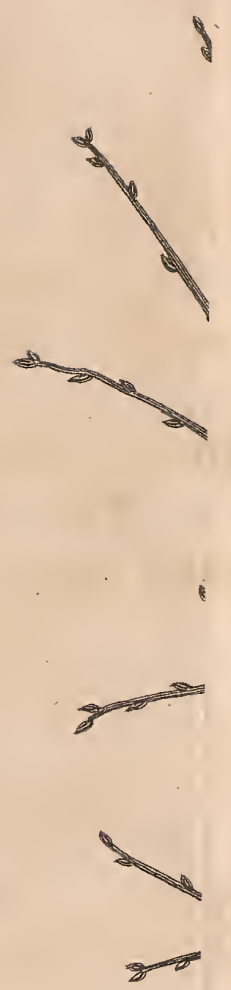

G.Crristie Del . 



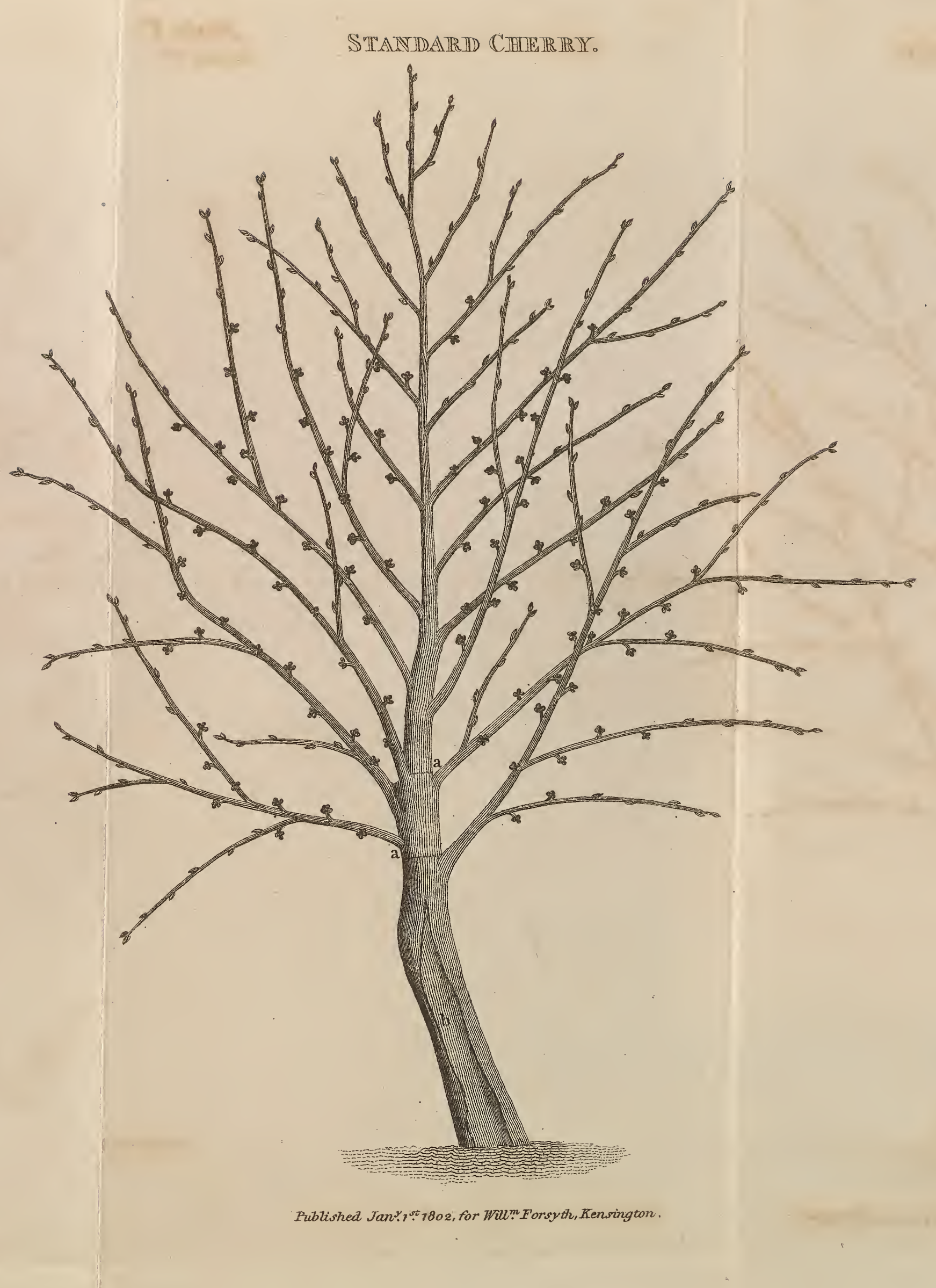






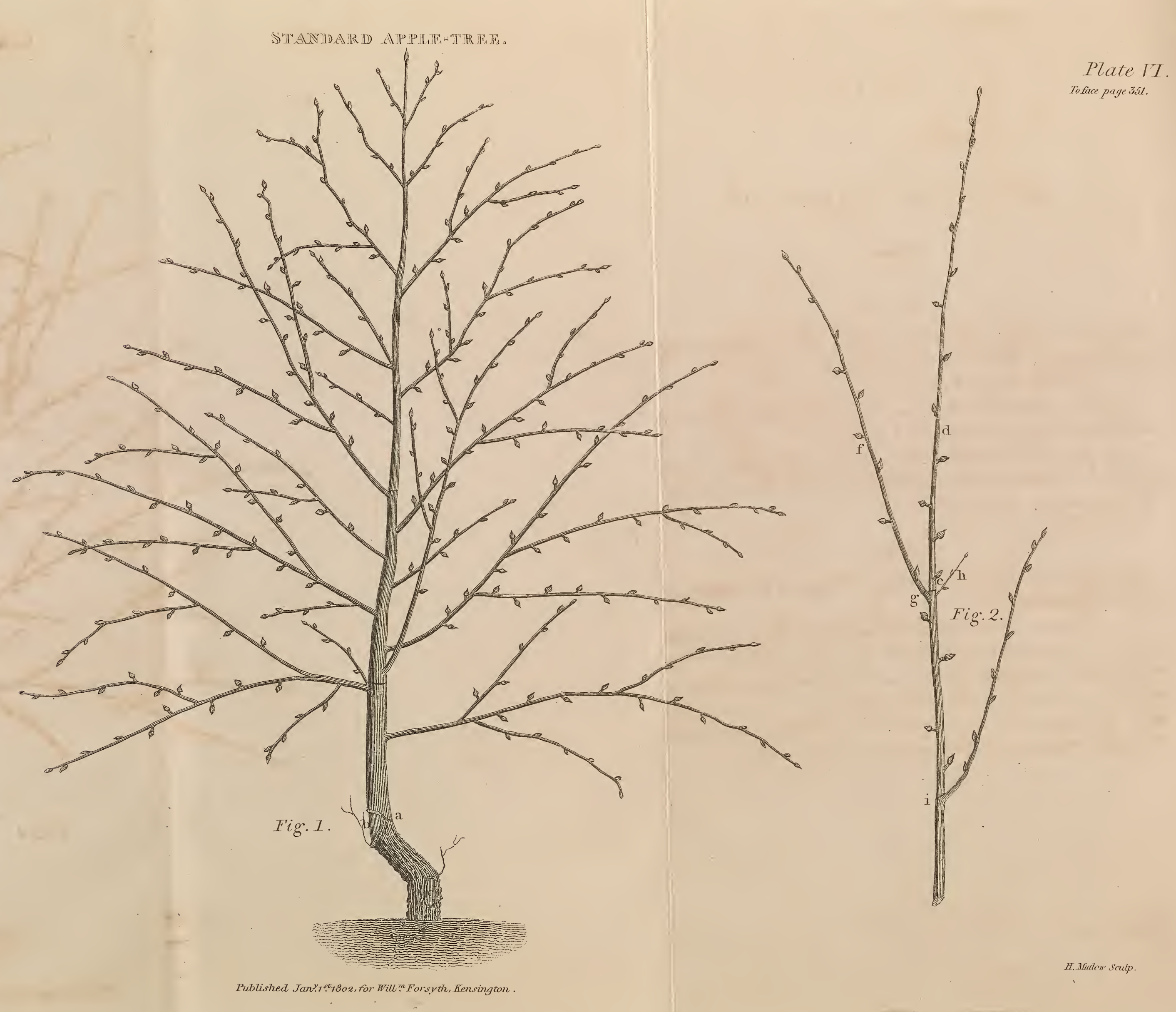





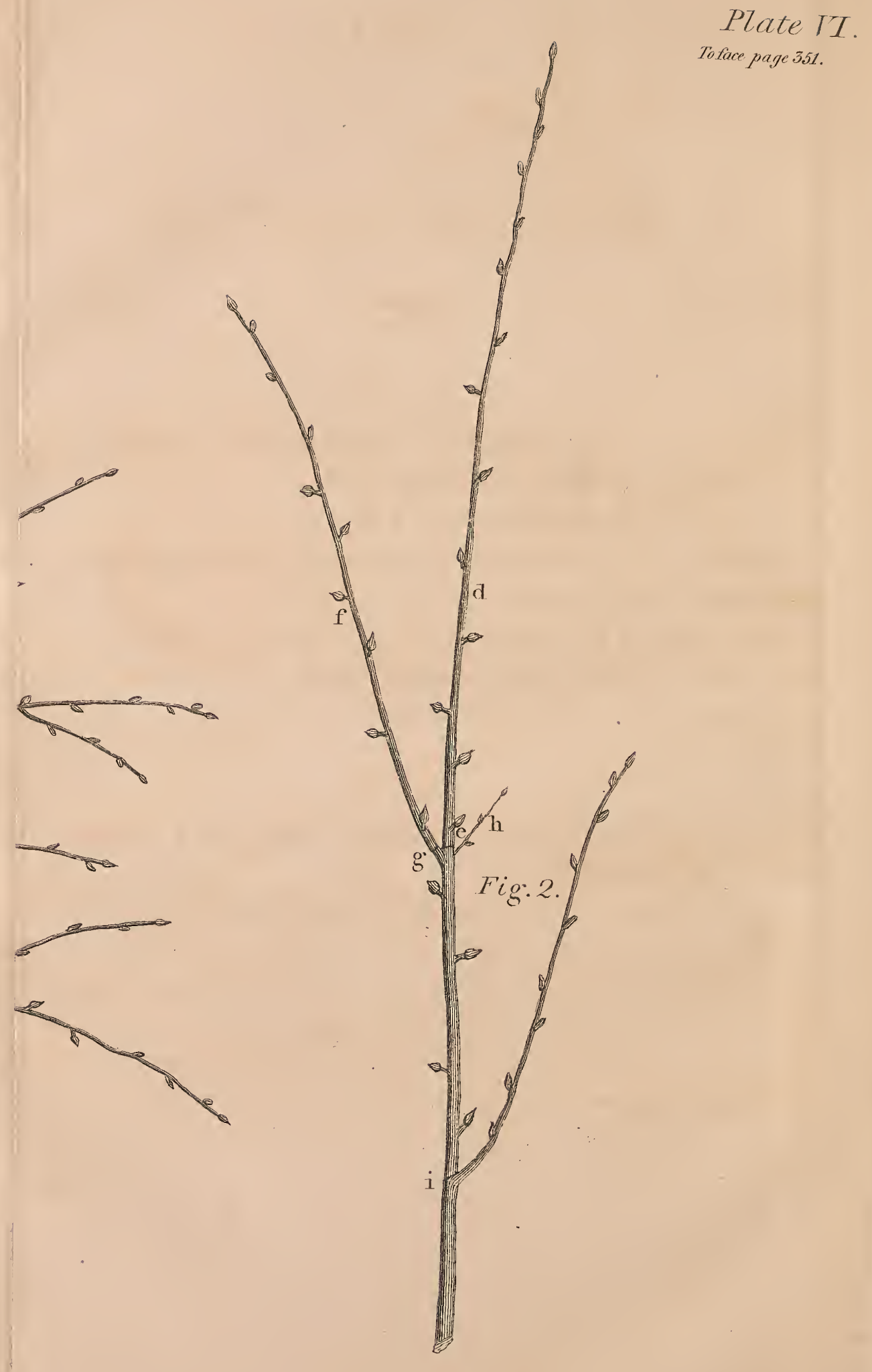


EXPLANATION OF PLATE VI.

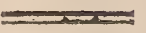

Fig. $I$.

An old cankery Apple-tree headed down four years ago, now bearing great plenty of fine fruit.

a. Where it was firft headed down.

$b$ and $c$. Two wounds covered with the Compofition, and now nearly filled up with found wood.

The part of the trunk below $a$ fhews the cankery ftate of the bark; which rough cankery bark muft always be pared off, otherwife it will infect the new.

\section{Fig. II.}

A branch thewing the method of keeping a regular fucceffion of bearing wood.

d. A branch, which has done bearing, to be cut at $e$, and which is fucceeded by the branch $f$; when that alfo is tired of bearing, it is to be cut at $g$, and will be fucceeded by the branch $b$; and when that alfo is worn out, it is to be cut off at $i$. By proceeding in this manner, you will always be able to keep a regular fucceffion of fine bearing wood. 
EXPLANATION OF PLATE VII.

\begin{abstract}
This Plate reprefents an old decayed Pear-tree, with four ftems, which was headed down, all but the branch $C$, and the young wood trained in the common way, or fan-falhion.

$A, A ; A$. Young wood producing the fine large fruit $B$.

C. An old branch pruned in the common way, having large fpurs ttanding out a foot or eighteen inches, and producing the diminutive, kernelly, and ill-flavoured fruit $D$, not fit to be eaten.

The two Pears $B$ and $D$, reprefented in the Plate of their natural fize, grew on the tree at the fame time.

$a, a, a, \& c$. Wounds in the ftems of the tree, with the Compofition applied, as they appeared when the edges of the bark began to grow over them.
\end{abstract}

 


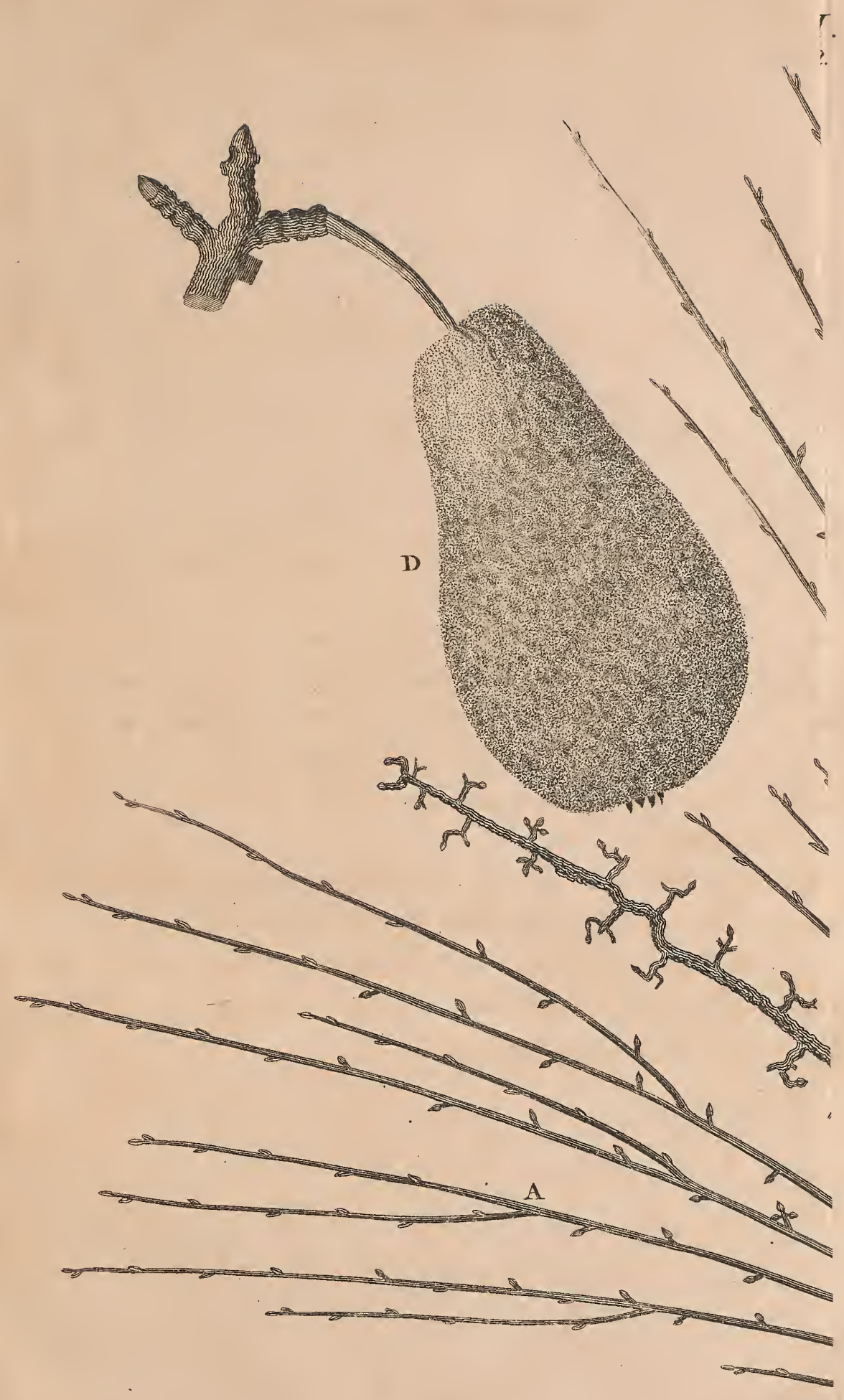

v $S c$.

G. Christie Del . 






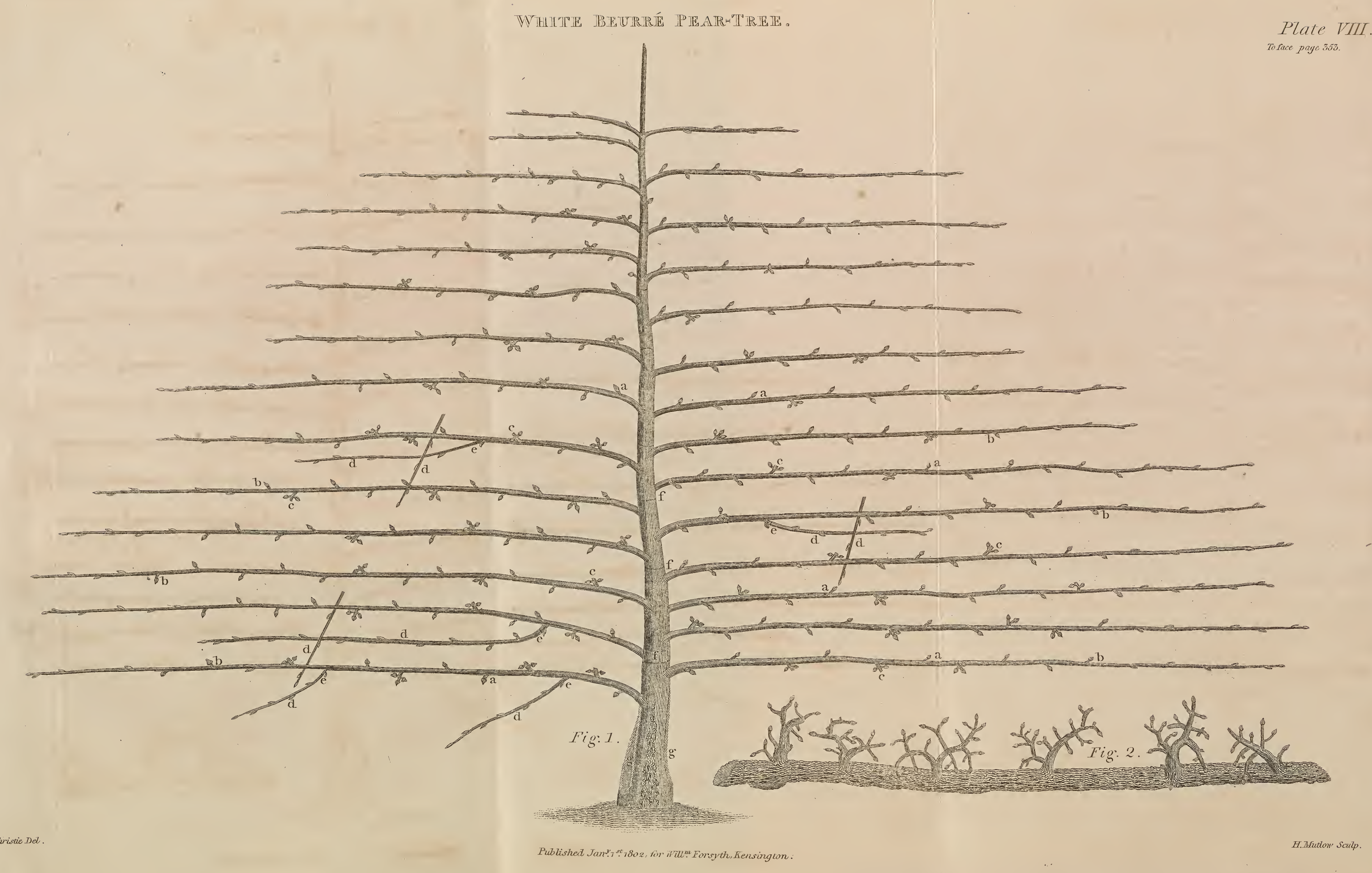



Plate VIII.

To face page 353. 
$(353)$

\section{EXPLANATION OF PLATE VIII.}

\section{Fig. I.}

AN old decayed Beurré Pear-tree headed down at $f$, and reftored from one inch and a half of live bark.

$a, a, a, \& c$. The fruit-buds for the prefent year.

$b, b, b, \& c$. Thofe forming for next year.

$c, c, \& \mathrm{c}$. The footfalks of the fruit of laft year, on which are forming buds for bearing in the fecond year.

$d, d, \&$ c. The foreright thoots as they appear before they are cut off at $e$, in the Autumn or Spring pruning.

$d$. The manner of tucking in the foreright branches.

$f, f, \& c$. Cicatrices of the different headings, which caufe the leading thoot to produce horizontal thoots.

$g, g$. Large wounds, having the Compofition applied, healing up.

Fig. II.

An old branch of the fame tree before it was headed down, trained and pruned in the old way, with fpurs ftanding out a foot, or a foot and a half, from the wall; and the rough bark, infefted with a deftruetive infer, which is defcribed and a method of cure given, in Cirap. XXVIII. See Coccus, and Plate IX. Fig. III. 


\section{EXPLANATION OF PLATE IX.}

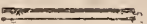

Fig. I:

An old Bergamot Pear headed down at the cicatrix $a_{5}$. taken from the wall and planted out as a dwarf ftandard.

b. A wound, covered with the Compofition, where a large upright thoot was cut off, to give the leading thoot freedom: to grow ftraight.

Fig. IT.

The different appearances of the infect fo deftructive to Pear-trees, mentioned in the Chapter on INSECTS, under the head Caterpillar.

This infect is inclofed in a cafe, and, when fixed on the leaf on which it feeds, appears as reprefented at $a, a, a$, which: is about its natural fize.

b. The cafe magnified:

c. The cafe, with the infect in motion, magnified.

d. The infeet magnified.

e. The Morti.

f. The Chryfalis.

g. The Chryfalis magnified.

Fig. III:

The Coccus which infefts Peach, Nectarine, and Pear trees. $a, a, a_{0}$. The infeet, the natural fize, on a branch of a pear-tree.

$b, b, b$. The fame magnified. 


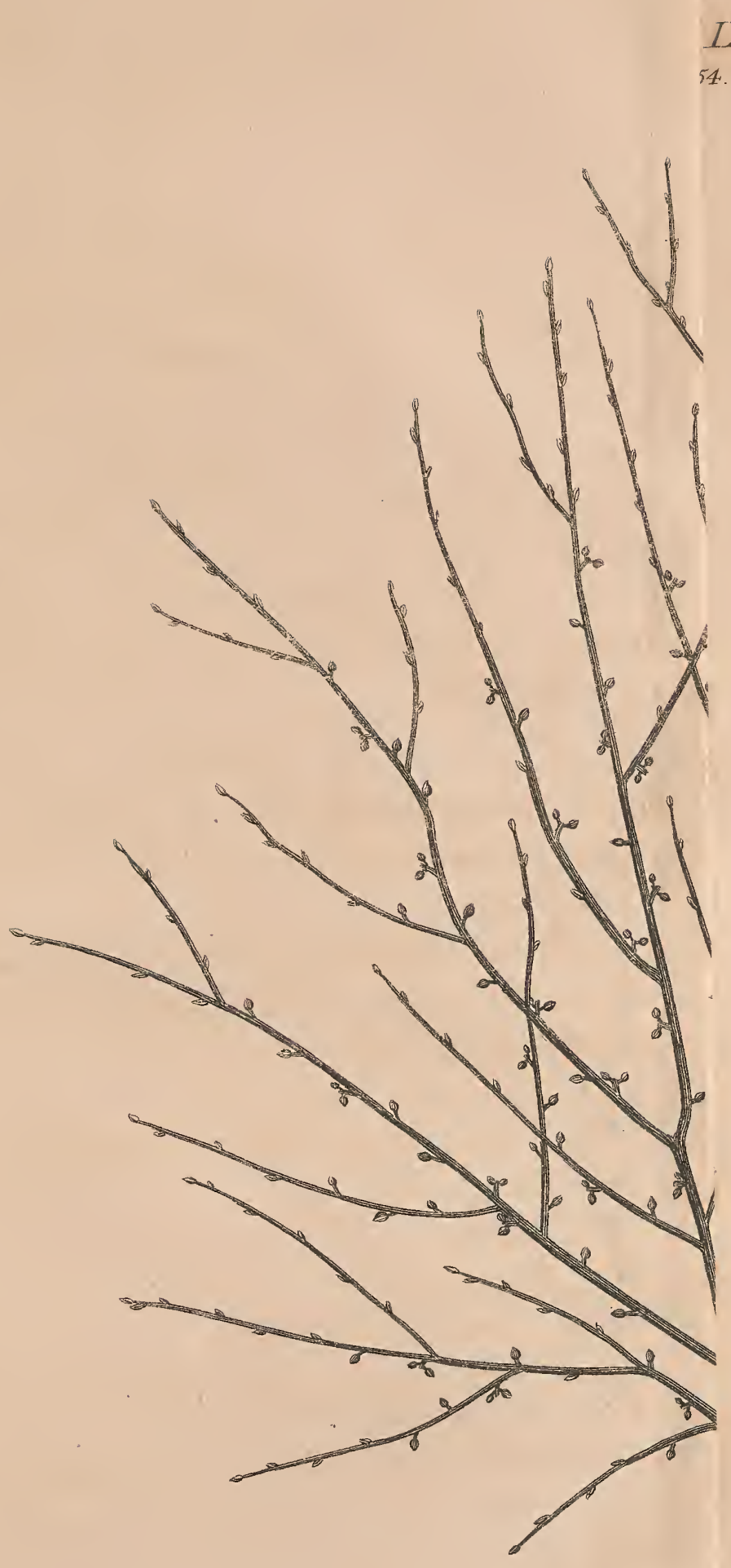

Fig. 1

GChristie Det .

$=$ = 



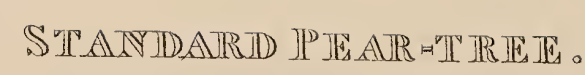

Plate IX.
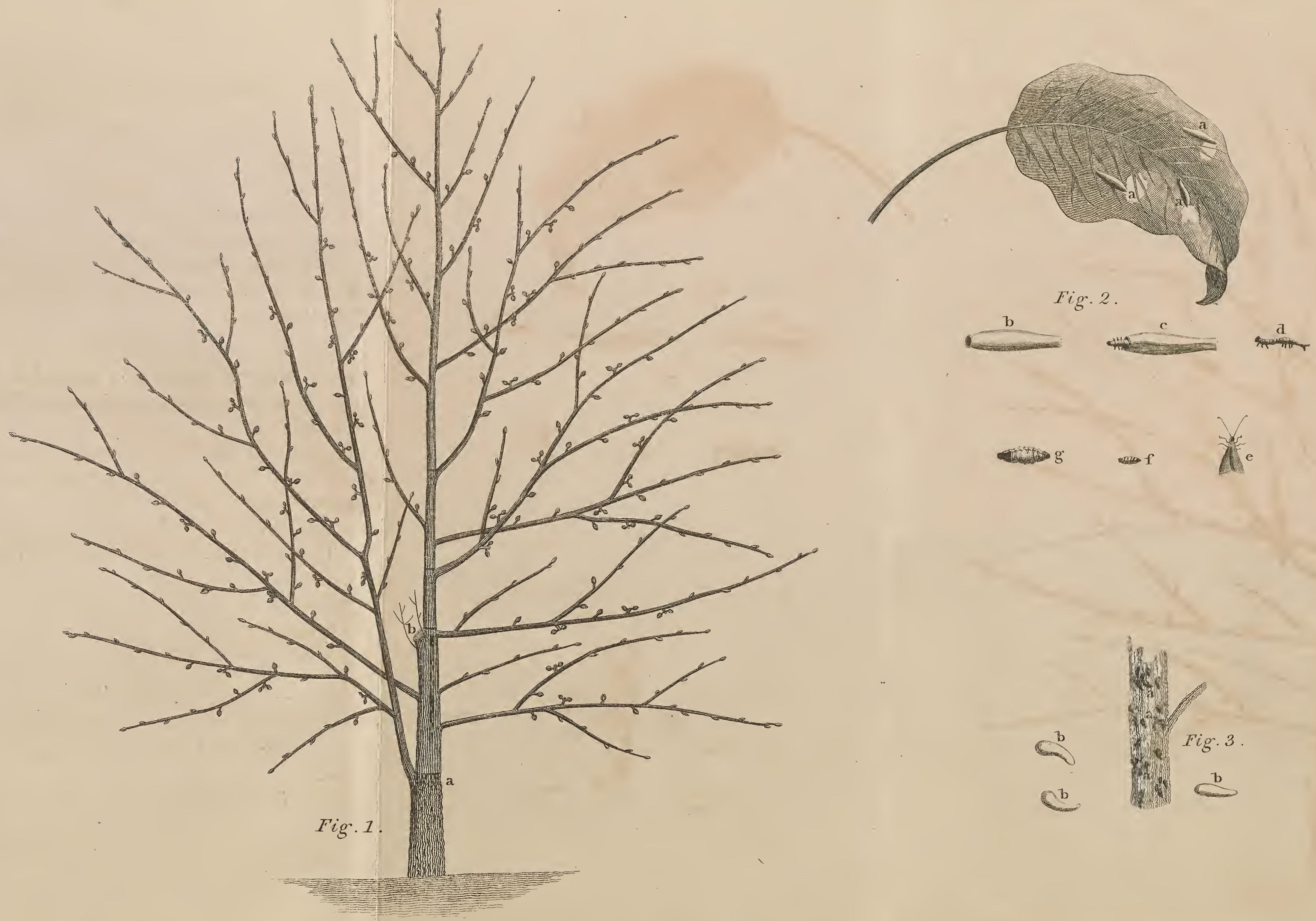




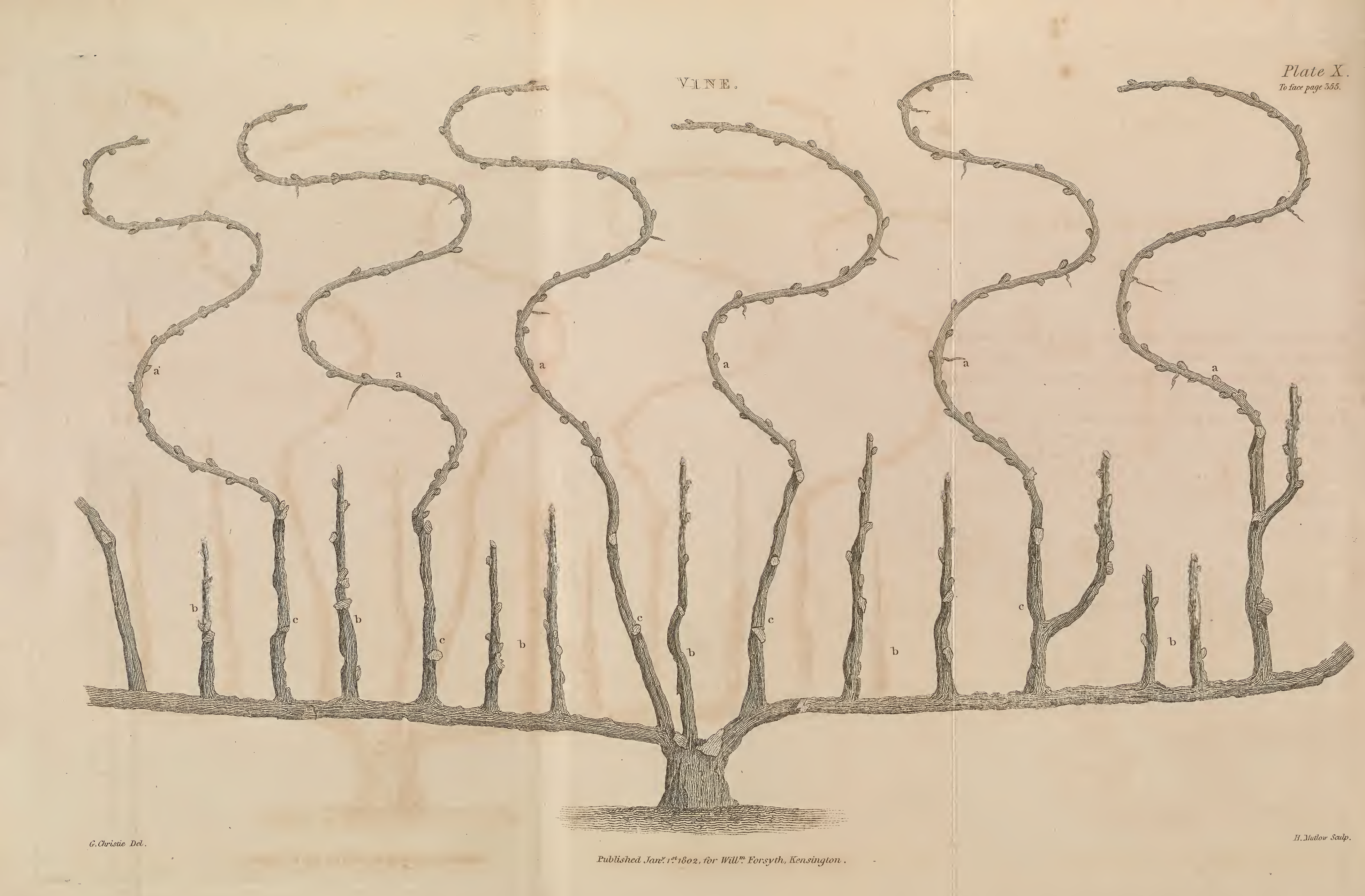





$$
\text { PQ }
$$


EXPLANATION OF PLATE X.

$a, a, a, \& z c$. The young bearing wood of a Vine trained in a ferpentine manner, with the buds for the prefent year appearing. Thefe thoots are generally cut out in the Winter pruning, as low as $c, c, c, \& c$. to produce wood for next year.

The fhoots $b, b, \& c$. produce fruit in the ufual manner, and alfo young wood for the following year, which muft not be topped, but only have the fide fhoots picked off. Two or three of the ftrongeft young thoots from each of thofe $b, b, \& c$. wrill be fuficient, and they muft be laid in at full length. 


\section{EXPLANATION OF PLATE XI.}

Fig. $I_{\text {. }}$

Grafting in the rind, thoulder-grafting, or crown-grafting. a. The ftock grafted.

b. The manner of raifing the bark to receive the cion or graft.

c. The graft prepared for inferting.

$$
\text { Fig. II. }
$$

Cleft-grafting, ftock-grafting, or flit-grafting.

d. The ftock grafted.

e. The ftock prepared for receiving the graft.

$f$. The cion ready for inferting.

$d, d, d$. Different views of incifions made for the purpore of obtaining young wood.

$e$. A young thoot coming out at the lower part of the incifion.

Fig. III.

Whip-grafting, or tongue-grafting.

g. The ftock grafted.

b. The ftock prepared.

i. The graft prepared for inferting.

Fig. IV o 


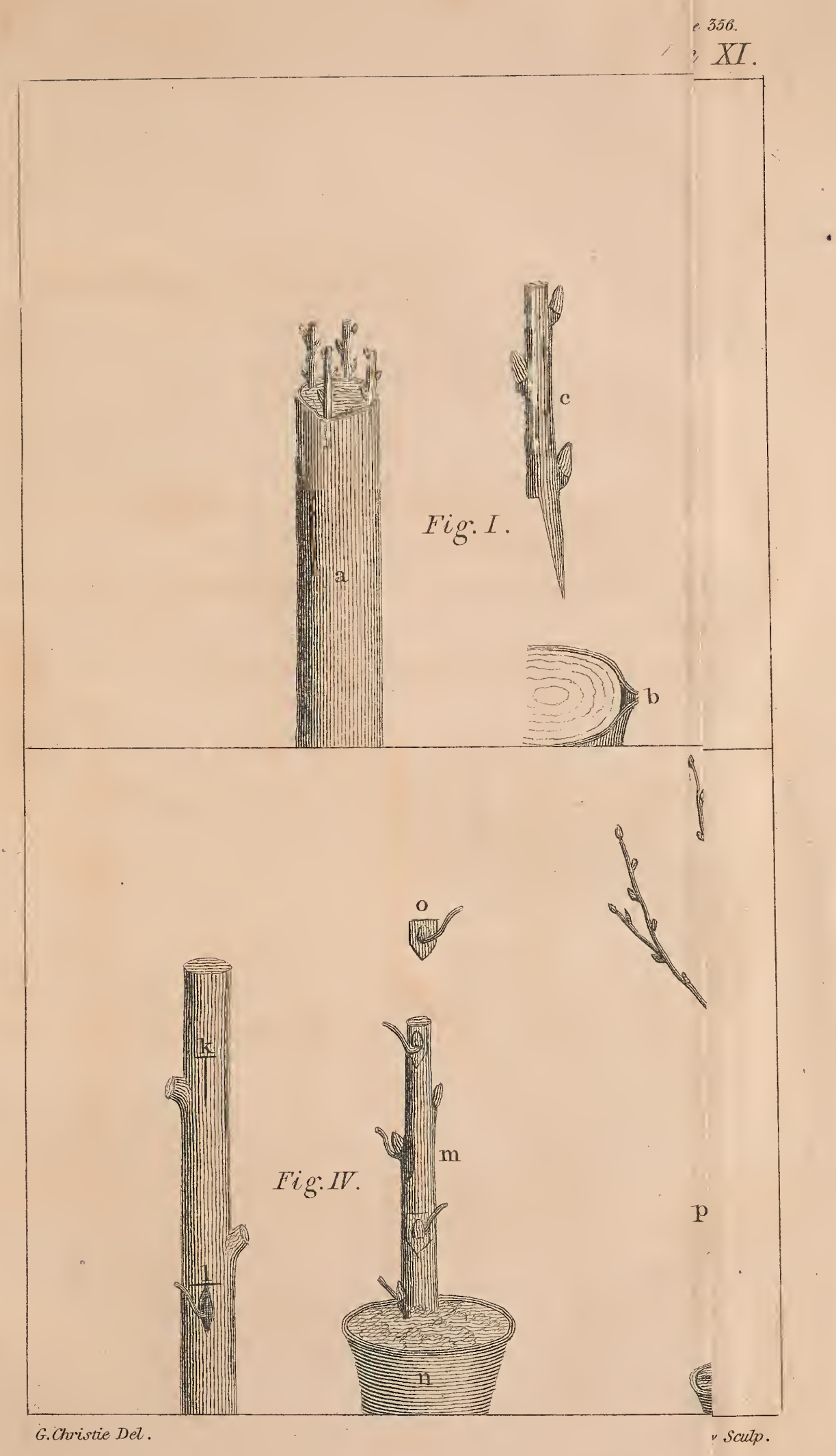





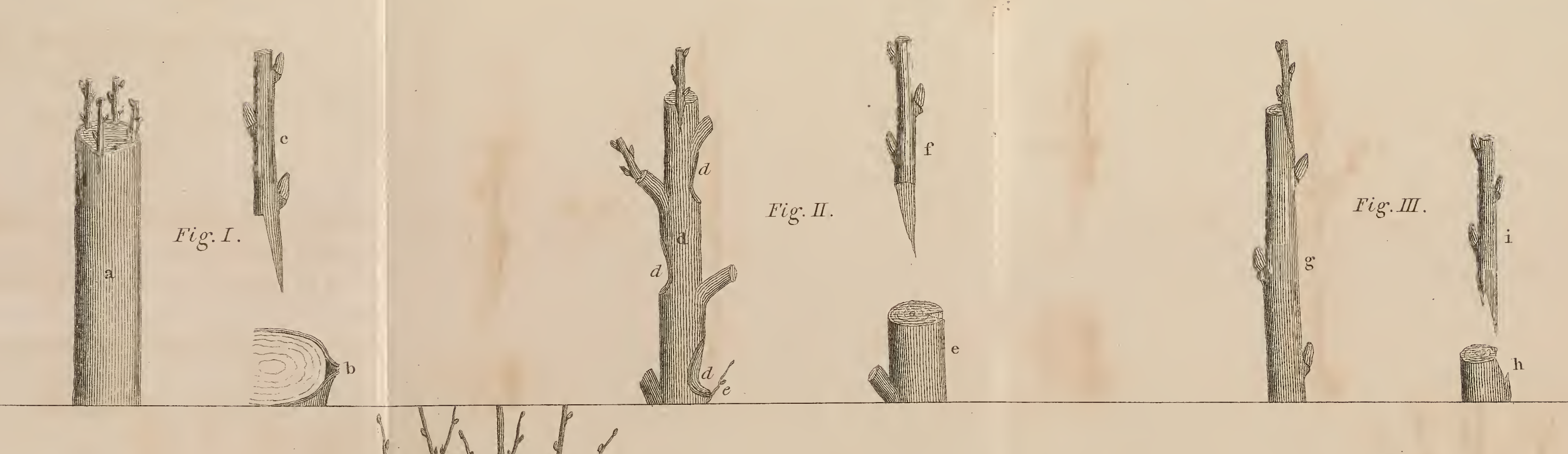

$$
\begin{aligned}
& 11 \sqrt{1}, \exists \text { ? }
\end{aligned}
$$





\section{$(357)$}

\section{Fig. IV.}

Inoculating or budding.

$k$. The manner of making the incifion in the bark.

l. The bud inferted, and the bark laid over it.

$m$. A fhoot thewing the manner of cutting off the buds.

$n$. A veffel with a little loam, covered with wet mofs, to fick the lower end of the fhoot in, to keep it moift till ufed.

o. A bud taken off, and ready for inferting.

$$
\text { Fig. } V \text {. and } V T \text {. }
$$

Inarching, or grafting by approach.

p. Grafting on a ftock in a pot.

$q$. Grafting on a ftock growing near the tree from which it is to be grafted on.

$r$, s. The thoot and ftock prepared.

t, t. Two branches inarched where the natural ones had failed, now properly united with the body of the tree; the lower parts being cut off.

$u, u$. Two branches lately inarched for the fame purpofe, and when properly united with the ftem, are to be cut off at $u, u, u, u$.

$w, x$. The manner of preparing the ftock and graft.

v. A natural fhoot coming out where the branch was inarched the preceding year. 
EXPLANATION OF PLATE XI.

Tins plate reprefents an old ftunted oak, which was headed down about fix years ago. At that time it was full of wounds and blemilhes, now nearly healed.

a. The place where the tree was headed, afterwards sovered with the Compofition.

$b, b, b$. Three young thoots produced fince heading; there were feveral others, which were cut down as they adwanced in growth; the two remaining fide ones are alfo to be cut down, and only the middle one left, which will in time cover the wound $a$, and form a proper tree.

$c, c, c$. Remains of the old wounds, covered with the Compofition, and now almont healed up. 


$$
\text { e XII. }
$$

rage 358 .

G. Christie Del.

Mutow So. 



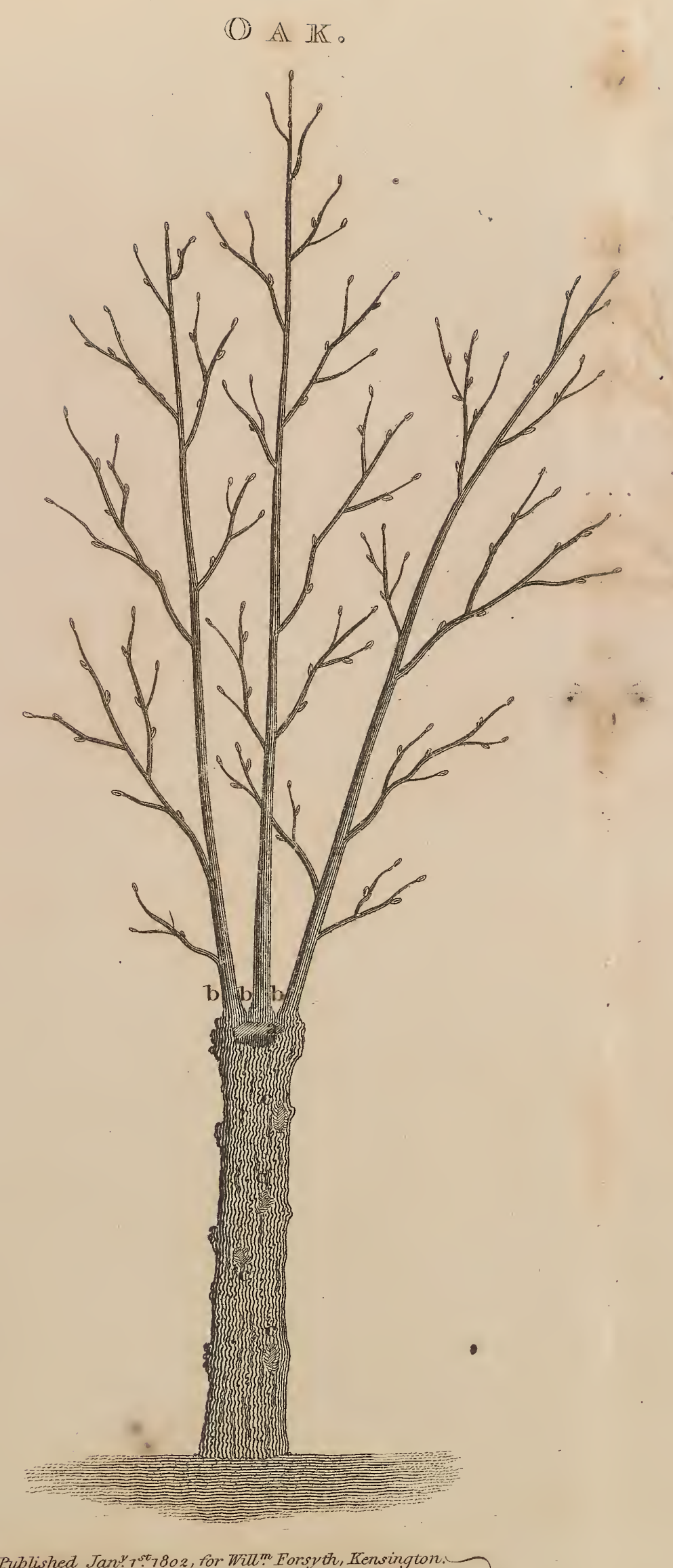

Plate XII.
To face page 358. 




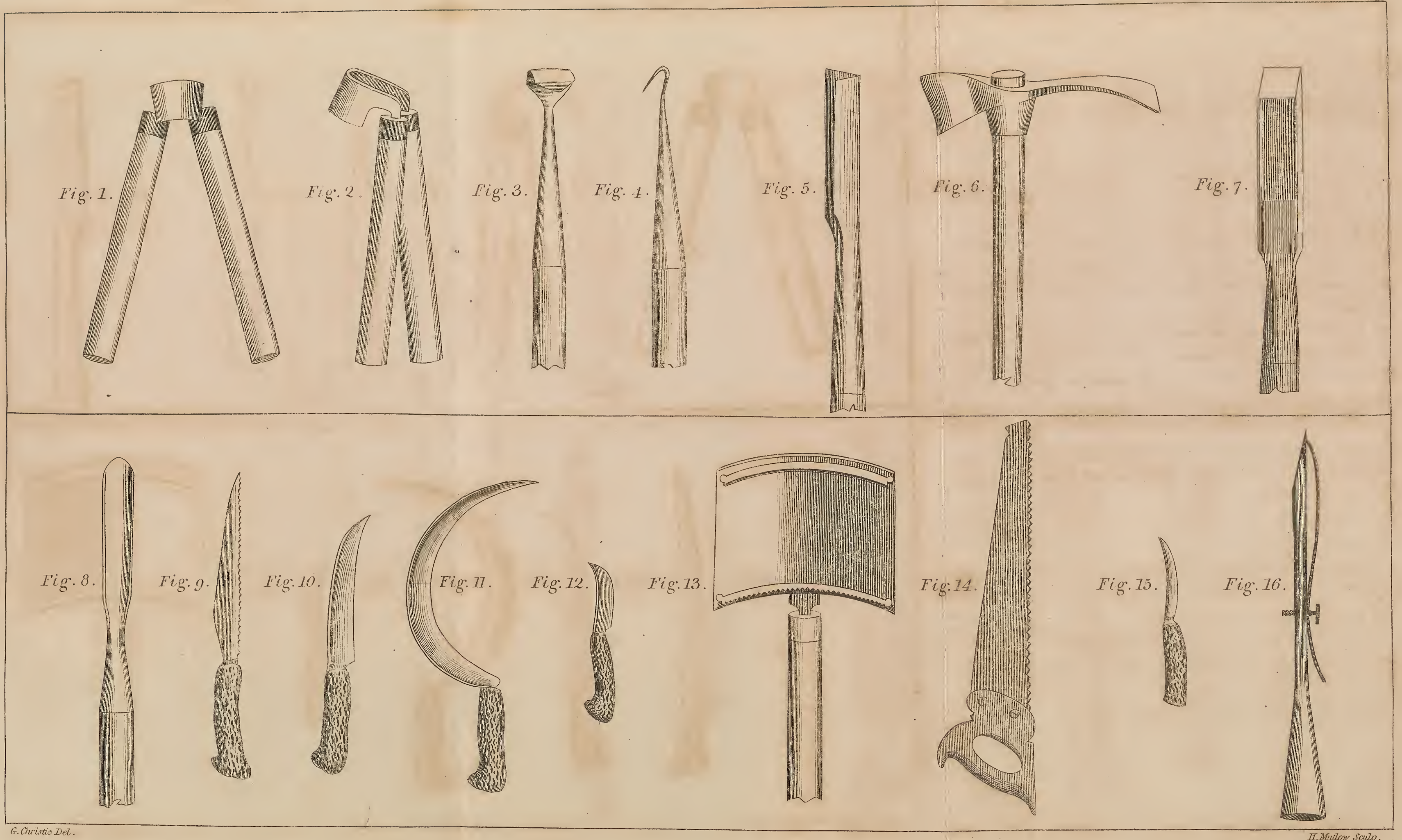





$$
\frac{91}{11}
$$




\section{EXPLANATION OF PLATE XIII.}

Fig. I and 2. Two different views of a tool for cutting out: the dead and decayed parts of hollow trees. It has. two wooden handles which may be of any convenient length.

3 and 4. Two views of another tool, with one handle, for cutting out dead wood. This is made narrower than the former, and is to be ufed in places where Fig. I. cannot be admitted.

5. A triangular chifel, for cutting grooves or channels. to carry off the water from the hollows of the trees.

6. A tool reprefenting an adze on one fide and a hat. chet on the other.

7. A large chifel.

8. A large gouge:

9. A fmall faw, with double teeth, thin on the back, for cutting off fmall branches, \&cc.

3.0. A knife with a concave edgre.

II. A tool in form of a fickle, without tecth. This is to fcrape frems and branches of trees on the fide next the wall.

82. A pruning knife with a convex edge.

Fig: $\mathbf{1 3}^{\circ}$ 
Fig. 13. A tool in thape of a curry-comb for feraping mofs, \& c. off the ftems and branches of trees: one of the fcrapers has teeth; the other is plain. The back of this tool, and the edges of the fcrapers, are a little concave.

4. A larger double-toothed faw for cutting off large branches.

15. A fmall pruning-knife with a convex edge.

x6. A large chifel with a ftrong plate of iron ferewed on upon the face of it, like a double iron for a plane, to prevent its running in too far where the tree is crofs-grained.

N.B. Thefe tools have handles of different lengths, to be iffed as occafion requires. 


\section{N D E X.}

A

A Carus, on Trees, how to destroy, 258.

on Melons, how to destroy, 261.

ALMONDS, different sorts of, 176 .

- Propagation of, 177.

How to prune, ibid.

Planting of, ibid.

How to preserve, 178.

ANTS, how to destroy them, 276.

APHIDES, described, 255.

How to destroy, 256.

APPLES, different sorts of, 57.

What sort of trees to chuse, 70.

- Heading of Dwarfs, ibid.

Heading down old Trees, 71.

- Hollow trees, how to be treated, 72.

Trees that are very cankery, or have ill-formed heads, should be headed down, ibid.

Pruning of Apple-trees, 73.

'The advantage of heading down young trees in the Nursery, 74.

Espaliers and Dwarfs, 75.

- Of borders and cross walks, 76.

How to improve the soil, ibid.

- Manure for Apple-trees, ibid.

- Grafting of old trees, 73.

Use of the Composition in grafting, ibid.

APRICOTS, different sorts of, 2. 
APRICOTS, Proper Trees, preparing the borders, and planting, 5.

Heading and training, 6.

Shortening the horizontal shoots, ibid.

- Old and decayed Trees, how to manage, 7.

- Injuries sustained by cutting or breaking off large branches, how to remedy, ibid.

Canker to cure, ibid.

- Topping young shoots, 8 .

Young shoots should be unnailed after the fall of the leaf, ibid.

Pruning, ibid.

- Objections to Autumnal pruning, ibid.

- Covering of Apricots, 9.

- How to have early and late crops, 10.

- Best sorts for standards, ibid.

B

BARBERRIES, different sorts of, 165 .

- Raising and pruning of Barberries, ibid.

BIRDS, To preserve fruit from them, 279.

BLIGHTS, what they are, and remedics for them, 251 to 254 .

BOMBYX, how to destroy, 273.

BUDDING, how performed, 206.

Observations on budding, 212.

- Use of the Composition in budding, 213.

\section{C}

CANKER, the description and causes of it, 241 .

Does not arise from the nature of the soil, 242.

Does not proceed from the roots to the branches, but from the

branches to the roots, 243 .

To cure the Canker, ibid.

OATERPILLARS, how to destroy, 267.

CHERMES, how to destroy, 272.

CHERRIES, different sorts of, 46 .

- Planting of them, 49.

Pruning and training, 50 . 
CHERRIES, Heading down, its advantages, and how performed, 50.

- Incisions for producing new wood, 51.

- The Canker in Cherry-trees, how to cure, ibid.

- The bad effects of the common way of pruning, and a remedy, 52 .

- Heart Cherries, how to prune, train, \&c. ibid.

- Value of Cherries, 53.

- Large Cherry-trees at Ashted-Park, Surry, 53, note.

- Manner of treating trees that produce spurs, 54 .

- Advantages of the new method of pruning and training, ibid.

- Heading down of old trees, 56.

CHESNUTS, Different sorts of, cultivated in England, 183.

Excellent timber, ibid.

- Great Chesnut of Tortworth, 184.

- Several large trees at Ashted Park, near Epsom, ibid. note.

Propagating of, 185.

Gathering, and keeping of Chesnuts in Winter, ibid.

Sowing, and management of Chesnuts in the Nursery, 18.6.

Planting out, 187.

- Heading down, 188.

CICADA, to destroy, 274.

COCCUS, Deseription of the Coccus, 263.

- How to destroy the Coccus, 264.

A new tribe, first appearance of them in England, 265.

COMPOSITION; Directions for making and applying it, 321.

Additional instructions, 323.

COVERING of Fruit-Trees to shelter them from frosts, \&c. 9, 37, 135.

CURRANTS, different sorts of, 153.

Propagation of Currants, 154.

Black Currants good for Coughs and Colds, 154, note.

Planting of, 155.

How to have an early crop, ibid.

- Pruning of, 156.

- To preserve them from insects, 157.

- Suckers must be stocked up, ibid.

EARWIGS, to destroy, 275.

\section{$\mathrm{E}$}

A A A

FIGS, 


\section{F.}

FIGS, different sorts of, 131 .

- Raising of, 134.

- Pruning and training of Fig-Trees, ibid.

- Sheltering them in Winter, 135.

Cautions about uncovering, 137.

2- To forward the ripening of Figs, ibid.

$=$ Leaves, and footstalks of late fruit to be taken off, 138 .

Training, and the distance at which Fig-trees should be planted, ibid.

_- Of sheltering standard Fig-trees from Frost, ibid.

- Heading down of Fig-trees, ibid.

- Figs may be dried for Winter use, 139.

FILBERTS. Sce NuTs.

FLIES. See WASPS.

FRUIT-ROOM. See the following Article.

FRUIT-GATHERING. The time and manner of gathering Apples and

Pears, and of carrying them to the Fruit-room, 233.

Of sweating, and laying up Apples and Pears on the shelves, 235.

How to keep them in Baskets, 237.

And in Jars, 238.

Of packing fruit for carriage, ibidw.

G

GARDEN, A proper situation for one, 215.

- How to shelter it by clumps, 216 .

- Of cross rows of Fruit-trees for shelter, ioid.

Of laying out a garden, 217.

Soil, 218.

Form and size, ibid.

Slips, outside of the wall, ibid.

Chevaux de frize, for paling, ibid. note.

Of watering a Garden, 219.

Quarters and Walks, 220.

GAR- 
GARDEN, Draining, 221.

Borders under the walls, 222 .

The Melon-ground and Pits, ibid.

- Map of a Garden proper to be had, 223.

Of Garden Walls, 224.

Gathering of frUit. See Fruit-gathering.

GOOSEBERRIES, different sorts of, with the weight of a great many new ones from Lancashire, 14.5, 14.6 .

Propagation and planting of Gooseberries, 147, 148.

Pruning, 149 .

Great attention paid to the cultivation of Cooseberries about Manchester, 1.50 .

Of early and late sorts, 151 .

Method of destroying Caterpillars on the bushes, 152.

GRAFTING, Definition, \&c. of Grafting, 194.

- On the choice of Grafts or Cions, 197.

Choice of Stocks, 198.

Tools necessary in Grafting, 199.

- Grafting clay, ibid.

- A composition of Bees-wax, \&c. instead of clay, 200.

Different ways of Grafting, ibid.

- Grafting in the rind, or shoulder-grafting, 201.

Cleft-grafting, 202.

Whip-grafting, or Tongue-grafting; ibid.

Graftíng by approach, 203.

Observations on Grafting, and the advantage of using the

Plaster-Composition instead of clay, 204.

GUM, a disease in Eruit-Trees, how to cure, 247.

\section{$\mathrm{H}$}

HONEY-DEW described, 250 .

How to be treated, 251.

I

INOCUlATiON. See Budding.

INSECTS. See ApHrs, Acarus, Coccus, \&ce 
LIME-WATER, how to make, 256.

\section{M}

MANURE for Fruit-Trees, 77.

MEDLARS, different sorts of, 143 .

Manner of Treatment, 144.

Should be planted at a distance from Apples and Pear's, ibid.

MrCE, how to destroy, 282.

MILDEW, what it is, 249 .

Remedy for it, 250.

MOSS, to destroy, and prevent from growing on Fruit-Trees, 231.

MULBERRIES, when introduced into England, 167.

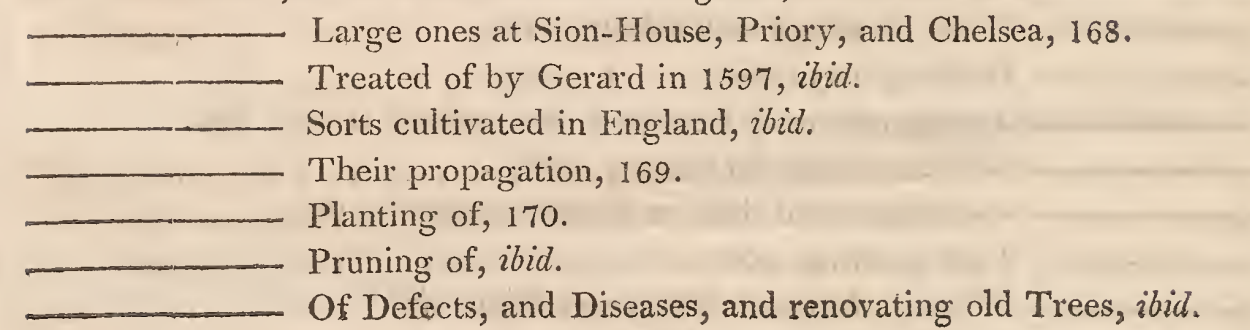

\section{$N$}

NECT ARINES, different sorts of, 40.

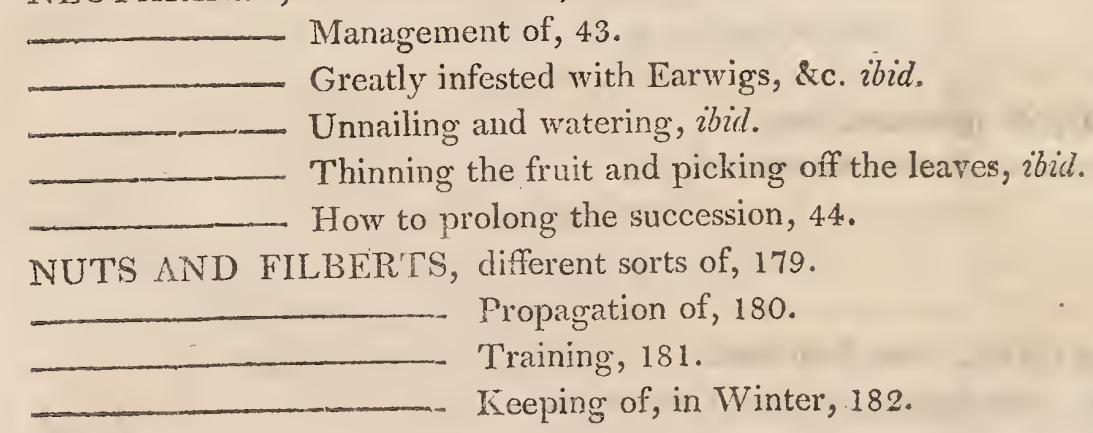


$\mathrm{O}$

OBSERVATIONS on the Diseases, Defects, and Injuries of Fruit and Forest

Trees. Published by order of Government. Introduction, 287.

What led to the discovery of the Composition, 288.

Enquirics of the Commissioners on the effects of the Composition, 289 .

Mr. Nichol's estimate of damaged timber brought into

Portsmouth Dock, 290, note.

General Observations on the Diseases of Trees, 294.

On the Management of Forest-Trees, 296.

First trial of the Composition on Forest-Trees, 300.

Of raising young timber from old roots or stumps, 302.

Correspondence with the Commissioners of the Land Revenue, 307.

A I.etter from the Commissioners to the Noblemen and Gentlemen appointed by Parliament to examine the Experiments in Kensington Garders, 314.

Report on the above examination, 316 .

Directions for making and applying the Composition, 321 . Additional Directions for making and applying the Composition, and for preparing the Trees, especially hollow ones, for receiving it, 323 .

Success of several Experiments since publishing the Observations, \&c. 329.

The best method of raising Oaks, 333 .

Of planting Chesnuts for Copse-wood, 334.

Letters attesting the efficacy of the Composition in diffe. rent climates, 3.36 .

ORANGE-TREES, directions for heading down, 343

ORCHARD, its situation, size, and soil, 226.

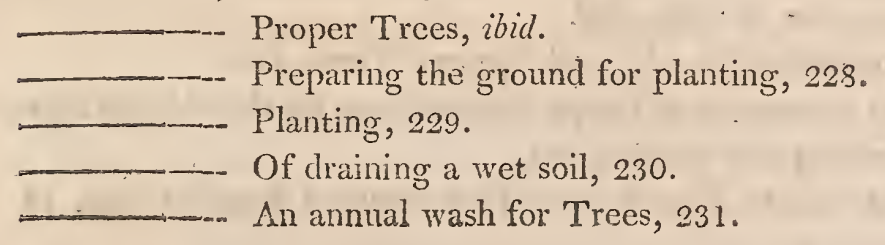


PAPILIO, how to destroy, 274.

PEACHES, different sorts of, 22.

Of the soil, and borders for Peaches, 28.

- Draining a wet soil, 29.

A sour wet clay, how to treat, 30 .

- Of the choice of Peach-Trees, ibid.

Preparing the borders and planting, ibid.

Heading, topping, pruning, and training, 31.

Pruning, training, and nailing of old Trees, 34.

Of making incisions, i $6 \imath_{i . .}$

The Canker, 35.

The superfluous foreright shoots to be rubbed off and the small branches to be tucked in, ibid.|

Of brushing off the leaves in Autumn, and unnailing the young branches, 36 .

Shreds that have been once used should be soaked in boiling hot soapsuds, to kill the eggs of insects before they are used again, ibid.

Of covering Peach-Trees, and thinning the fruit, 37.

- The great advantage of using the Composition, ibid.

- Of watering and mulching, 38.

- The late side-shoots must be taken off, ibid. .

- Of picking off the leaves, $\vec{i} b i d$.

- To procure a regular succession, 39.

- Sorts for North and East walls, ibid.

PEARS, different sorts of, 80,81 .

Choice of Trees, and planting, 94.

Heading, 95.

Stunted trees, how to treat, ibid.

Pruning, 96.

Cankery Trees, how to treat, ibid.

Experiments on unfruitful, old, and decayed Trees, ibid.

A comparative statement of the produce of trees by the old and new way of pruning and training, 97 .

Description of an old Beurré Pear-Tree restored from $1 \frac{x}{2}$ inch of sound bark, 99.

PEARS, 
PEARS, of training Trees that are headed down near to the place where they have been grafted, 100.

Of the Canker and its Remedy, 101.

Shortening the foreright shoots, ibid.

Of decayed and rotten roots, 102.

Trenching the borders, ibil.

A remedy for stunted Pears, ibid.

The distance at which Pear-trecs should be planted from eacly other, 103.

Of borders, and the proper depth of mould, 104 .

How the Trees ought to be treated in a clayey soil, ibid.

Proper small crops for the borders, ibid:

PHALEN Æ, how to destroy, 272.

- See Bonibyx.

POISON, for Vermin. See RATS and Mice.

PLUMS, different sorts of, 11 .

Choice of Trees, management of the Borders, and planting, 15.

Heading-down, 16.

Distance at which Plum-trees should be planted, ibid.

Training, and shortening the leading shoot, ibid.

- Preparing Wall-trees for standiards, and transplanting them, $1 \%$.

Trenching the Borders, $1 \mathrm{~s}$.

Of.Standards in Orchards, and Dwarfs in Gardens, ibid.

of Cross-rows in Gardens, ii id.

Of.pruning and restoring old and decaycd trees, 19.

Of foreright shoots, 20.

Sheltering from frosts and cold winds, ibid.

- The Composition ought always to be applied after the knife, 21 .

Of thinning the fruit. ibid.

POTS, number of, in a cast, 113 , note.

Q

QUINCES, best sort of, for the kitchen garden, 140.

- Propagation, planting, and pruning of them, $14 \mathrm{l}$.

Rough bark, and bark bound trees, 142.

Should be planted at a distance from Apples and Pears, ibit.

B. B B

RASP. 
$\mathbf{R}$

RASPBERRIES, different sorts of, 159.

- Propagation and planting, 160.

-Watering and slaking, 161.

- Pruning, 162.

- The time they will continue in a bearing state, $z$ ibid.

RATS, How to destroy them, 281.

\section{$\mathrm{S}$}

SERVICE, Different sorts, 172.

The cultivited Service, ibid.

- How propagated, 173.

- Training and pruning, ibid.

- The Wild Service, or Mountain Ash, 174.

Its Propagation, ibid.

Training, ibid.

The Maple-leaved Service 175.

Its propagation, training, \&c. ibid.

SLUGS, to destroy, 277.

SNAILS, to destroy, ibid.

SPHINX, to destroy, 273.

STOCKS for grafting on, choice of, 198.

T

THRIPS, how to destroy, 272.

TRANSPLAN'TING of old trees, 17, 18.

TRELS. For the Management of Fruit-trees. See Apples, PEArs, PlUMs, \&c。

Forest trees, how to manage. See "Observations on the Diseases, Defects, \&c. of Trees."

TRAPS for catching Vermin. See Rats and MicE.

\section{V}

VEGETABLE Mould, how produced, 76, 77.

VINES, different sorts of, 106. 
VINES, Of propagating Vines from seed, 113.

_ - _ - - f from cuttings, 115 .

- - - - - from layers, 118.

Of choosing Vines from the Nursery, 119.

- Experiments and Observations on training and pruning of Vines, 121.

Directions for training and pruning, 123.

Use of the Composition after pruning, 127.

- Directions for watering Vines, $i b i d$.

Of preserving Grapes from Flies, Wasps, \&c. 128.

Of picking off the leaves, 129.

Gathering and preserving Grapes in Winter, ibid.

W

W ALNUTS, different sorts cultivated in England, 190.

Propagation and treatment in the Nursery, 191.

Planting out, $i b i d$.

Trimming, 192.

Walnut-trees, excellent timber, $i b i d$.

Leaves of, serviceable in destroying Slugs, 193.

Method of keeping Waluuts, ibid.

Value of Walnut-trees at Beddington Park, annually, ibid. note.

WASH, annual, for trees, 231.

WASPS, to destroy, 278.

WATERING. Directions for watering trees, 38.

See also Mrldew, Aphis, Acarus, \&c. where directions are given for watering under different circumstances.

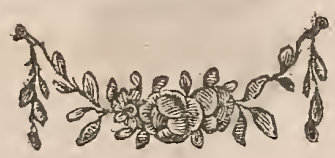


** This Wont ts now translating mio French, under the inspection of the Author, by L'ABBE' JOFFRIN, a genticman well qualified for such an undertaking.

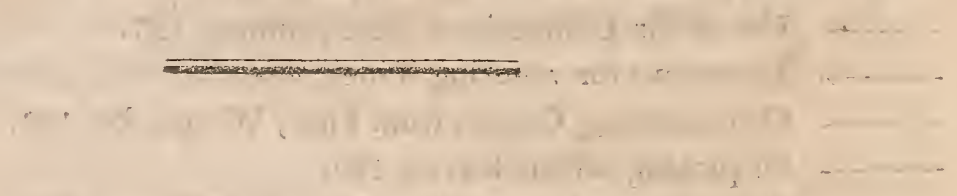

\section{E R R A T A.}

Tage 3 , line 2 from the bottom, for in Spring Grove, read at Spring Grove.

20, - 8 from the bottom, for Fig. 2. read Fig. 2. and 3 .

$3 \mathrm{I},-3$, for before given, read hereafter giren.

32 , -6 and 7 from the bottom, for and cut them clofe that they may; read and cut it clofe that it may.

$49,-8$ of column I, for Church-hills, regd Churchill's Heart.

$56,-3$, for and would, read and he would.

$6_{3},-1$, and alfo in the note, for Pomme Gree, read Pomme Grife.

$5 \%$, - I5 of column I, for Norfolk Beaufin, read Norfolk Beefin..

68, - 2 of column 2, for Minehall, read Minchall Crab.

69, - 2 r, 'for Pomme Gree, read Pomme Grife.

86, - 10, for Martin See, read Martin Sec.

90, - 10, Green Pear of Pinkey thould have begun a new paragraph.

91, - 8, for Boncrêtien, read Bonchrêtien.

$99,-2$ from the bottom, for an incn, read an inch.

$26 \mathrm{r},-3$, for departure fro, read departure from.

$2 \sigma_{3}$, - II, for fprinkle, read fprinkle.

265 , - 20, for depretions, read depredations.

267, , 2 from the bottom of the note, for work their way, read work theis. way out.

- $3255^{\circ}$ - 14, for advances, read advanee.

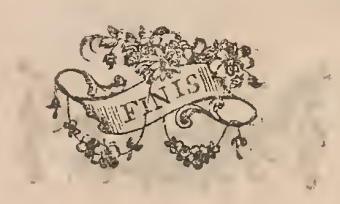

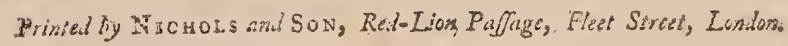











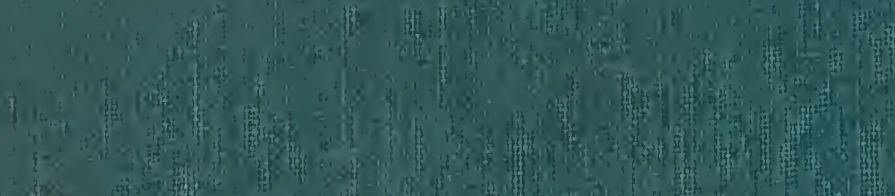

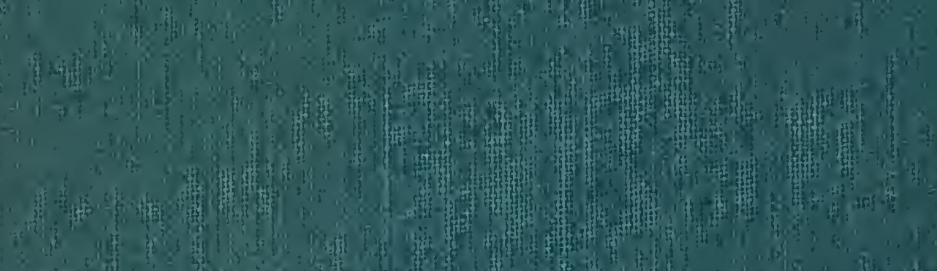

(3) 